DOE/ET/27163-4

Distribution Category UC-66f

\title{
EXECUTIVE SUMMARIES OF REPORTS
}

LEADING TO THE CONSTRUCTION OF

THE BACA GEOTHERMAL DEMONSTRATION PROJECT

Prepared By

P.B. Sherwood

K.L. Newman

J.F. Westermeier

H.D. Giroux

G.D. Lowe

M.W. Nienberg, Dr.P.H.

WESTEC Services, Inc.

505 Marquette, N.W.

Albuquerque, New Mexico

Date Published - May 1980

Prepared For

UNION GEOTHERMAL COMPANY OF NEW MEXICO

AND

PUBLIC SERVICE COMPANY OF NEW MEXICO

UNDER CONTRACT NO. GEO-CSL-25

Work Sponsored By

THE U.S. DEPARTMENT OF ENERGY

DIVISION OF GEOTHERMAL ENERGY

UNDER COOPERATIVE AGREEMENT NO. DE-FC03-78ET27163 


\section{DISCLAIMER}

This report was prepared as an account of work sponsored by an agency of the United States Government. Neither the United States Government nor any agency Thereof, nor any of their employees, makes any warranty, express or implied, or assumes any legal liability or responsibility for the accuracy, completeness, or usefulness of any information, apparatus, product, or process disclosed, or represents that its use would not infringe privately owned rights. Reference herein to any specific commercial product, process, or service by trade name, trademark, manufacturer, or otherwise does not necessarily constitute or imply its endorsement, recommendation, or favoring by the United States Government or any agency thereof. The views and opinions of authors expressed herein do not necessarily state or reflect those of the United States Government or any agency thereof. 


\section{DISCLAIMER}

Portions of this document may be illegible in electronic image products. Images are produced from the best available original document. 
DISCLAIMER

"This report was prepared as an account of work performed by Union Geothermal Company of New Mexico, Public Service Company of New Mexico, and the U.S. Department of Energy, an agency of the United States Government. Neither Union Geothermal Company of New Mexico, nor Public Service Company of New Mexico, nor the United States Government nor any agency thereof, nor any of their employees or subcontractors, makes any warranty, express or implied, or assumes any legal liability or responsibility for the accuracy, completeness, or usefulness of any information, apparatus, product, or process disclosed, or represents that its use would not infringe privately owned rights. Reference herein to any specific commercial product, process, or service by trade name, trademark, manufacturer, or otherwise, does not necessarily constitute or imply its endorsement, recommendation, or favoring by Union Geothermal Company of New Mexico, or Public Service Company of New Mexico, or the United States Government or any agency thereof. The views and opinions of authors expressed herein do not necessarily state or reflect those of Union Geothermal Company of New Mexico, or Public Service Company of New Mexico, or the United States Government or any agency thereof."

Printed in the United States of America

Available from:

WESTEC Services, Inc.

505 Marquette N.W., Suite 1000

Albuquerque, NM 87102 


\begin{abstract}
Executive summaries have been written for 61 reports and compilations of data which in part, have led to the construction of the Baca $50 \mathrm{MW}$ Geothermal Demonstration Project (GDP). The reports and data include environmental research, reservoir and feasibility studies, the project proposal to DOE and the Final Environmental Impact Statement. These executive summaries are intended to give the reader a general overview of each report prior to requesting the report from the GDP Data Manager.
\end{abstract}




\section{BACA PROJECT \\ PRELIMINARY DATA AND REPORTS \\ TABLE OF CONTENTS}

\section{ENVIRONMENTAL}

\begin{tabular}{|c|c|c|c|c|}
\hline REPORT & TITLE & $\begin{array}{l}\text { APF } \\
\text { NO. } \\
\end{array}$ & $\begin{array}{l}\text { ROX. } \\
\text { PAGES }\end{array}$ & PAGE \\
\hline 1 & $\begin{array}{l}\text { "Preliminary Investigation Hydrogen } \\
\text { Sulfide Background Levels, Baca Location } \\
\text { No. 1, New Mexico," Stearns-Roger, Inc., } \\
\text { December } 1975 .\end{array}$ & $\begin{array}{r}137 \\
25\end{array}$ & $\begin{array}{l}\text { Text } \\
\text { Data }\end{array}$ & 1.0 \\
\hline 2 & $\begin{array}{l}\text { "Second Progress Report Meteorological } \\
\text { and Hydrogen Sulfide Background Ob- } \\
\text { servations, Baca Location No. 1, New } \\
\text { Mexico," by Stearns-Roger, Inc., June } \\
\text { 1975. }\end{array}$ & $\begin{array}{r}25 \\
350\end{array}$ & $\begin{array}{l}\text { Text } \\
\text { Data }\end{array}$ & 2.0 \\
\hline 3 & $\begin{array}{l}\text { "Third Progress Report Meteorological } \\
\text { and Hydrogen Sulfide Monitoring Programs, } \\
\text { Baca Location No. 1, New Mexico," by } \\
\text { Stearns-Roger, Inc., October } 1975 .\end{array}$ & $\begin{array}{r}50 \\
325\end{array}$ & $\begin{array}{l}\text { Text } \\
\text { Data }\end{array}$ & 3.0 \\
\hline 4 & $\begin{array}{l}\text { "Preliminary Ground-Level Hydrogen } \\
\text { Sulfide Concentration Estimates, Baca } \\
\text { Location No. 1, New Mexico," Stearns- } \\
\text { Roger, Inc., December 1975. }\end{array}$ & $\begin{array}{r}11 \\
8\end{array}$ & $\begin{array}{l}\text { Text } \\
\text { Data }\end{array}$ & 4.0 \\
\hline 5 & $\begin{array}{l}\text { "Annual Report Meteorological and Air } \\
\text { Quality Monitoring Programs, Baca Lo- } \\
\text { cation No. 1, New Mexico," by Stearns- } \\
\text { Roger, Inc., February } 1976 .\end{array}$ & $\begin{array}{r}51 \\
148\end{array}$ & $\begin{array}{l}\text { Text } \\
\text { Data }\end{array}$ & 5.0 \\
\hline 6 & $\begin{array}{l}\text { "Baca Ranch Geothermal Site Geothermal } \\
\text { Radiological Monitoring Program," by } \\
\text { Controls for Environmental Pollution, } \\
\text { Inc., November } 1974 \text {. }\end{array}$ & $\begin{array}{l}50 \\
67\end{array}$ & $\begin{array}{l}\text { Text } \\
\text { Data }\end{array}$ & 6.0 \\
\hline 7 & $\begin{array}{l}\text { "The Biota of Redondo Creek Canyon, } \\
\text { Sandoval County, New Mexico, with } \\
\text { Emphasis on Big Game Species and Rare, } \\
\text { Endangered or Threatened Species," by } \\
\text { Southwest Environmental Research and } \\
\text { Development Corporation, October } 1974 \text {. }\end{array}$ & $\begin{array}{l}55 \\
16\end{array}$ & $\begin{array}{l}\text { Text } \\
\text { Data }\end{array}$ & 7.0 \\
\hline
\end{tabular}


ENVIRONMENTAL (Continued)

\begin{tabular}{|c|c|c|c|c|}
\hline REPORT & TITLE & $\begin{array}{r}\text { API } \\
\text { NO. }\end{array}$ & $\begin{array}{l}\text { ROX. } \\
\text { PAGES }\end{array}$ & $\underline{\text { PAGE }}$ \\
\hline 8 & $\begin{array}{l}\text { "Report on Reconnaissance of Redondo } \\
\text { Creek, Redondo Border, Sulfur Canyon, } \\
\text { Alamo Canyon and Valle Seco Areas with } \\
\text { Proposals and Budget Estimates for } \\
\text { Biological Baseline Studies," Whitford } \\
\text { Ecological Consultants, May 1975. }\end{array}$ & 15 & Text & 8.0 \\
\hline 9 & $\begin{array}{l}\text { "Winter Activity and Habitat Use by Elk } \\
\text { in the Redondo Creek Area with Comments } \\
\text { on Activities and Relative Abundance of } \\
\text { Other Species," by Whitford Ecological } \\
\text { Consultants, August } 1975 \text {. }\end{array}$ & 37 & Text & 9.0 \\
\hline 10 & $\begin{array}{l}\text { "The Biota of the Baca Geothermal Site," } \\
\text { by Whitford Ecological Consultants, } \\
\text { November } 1975 .\end{array}$ & $\begin{array}{r}102 \\
36\end{array}$ & $\begin{array}{l}\text { Text } \\
\text { Data }\end{array}$ & 10.0 \\
\hline 11 & $\begin{array}{l}\text { "Studies of Rare and/or Endangered } \\
\text { Species on the Union-Baca Geothermal } \\
\text { Lease and Surrounding Area with Dis- } \\
\text { cussion of Other Species," by Whitford } \\
\text { Ecological Consultants, 1977. }\end{array}$ & 32 & Text & 11.0 \\
\hline $\begin{array}{l}12 \\
13 \\
14\end{array}$ & $\begin{array}{l}\text { "Hydrology of the Region Surrounding the } \\
\text { Valles Caldera", with Appendices and } \\
\text { Addendum by Water Resources Associates, } \\
1977 .\end{array}$ & $\begin{array}{r}114 \\
103 \\
+7\end{array}$ & $\begin{array}{l}\text { Text } \\
\text { Data } \\
\text { Maps }\end{array}$ & 12.0 \\
\hline \multicolumn{5}{|c|}{ WELLS } \\
\hline REPORT & TTTLE & \multicolumn{2}{|c|}{$\begin{array}{l}\text { APPROX. } \\
\text { NO. PAGES }\end{array}$} & $\underline{\text { PAGE }}$ \\
\hline 15 & Summary sheet for Baca Wells Nos. 1-3. & $\begin{array}{l}4 \\
2\end{array}$ & $\begin{array}{l}\text { Text } \\
\text { Data }\end{array}$ & 15.0 \\
\hline 16 & Baca Wells Nos. 4-16 summary sheet. & 3 & Data & 16.0 \\
\hline 17 & $\begin{array}{l}\text { Well summary reports and Drilling } \\
\text { Histories - Baca Wells Nos. 4-16. }\end{array}$ & 113 & Data & 17.0 \\
\hline 18 & Lithology Logs - Baca Wells Nos 4-16. & 8 & Logs & 18.0 \\
\hline
\end{tabular}


REPORT

19

20

Electric Logs for Baca Wells Nos. 10-14.

TITLE

Temperature and Pressure Surveys Baca Wells Nos. 4-8 and 10-16.

\section{GEOLOGY}

REPORT

TITLE

21

"Hydrothermal Geology of the Valles

Caldera, New Mexico," by R.F. Dondanville, 1971.

22 "Airborne Infrared Geothermal Exploration, Valles Caldera, New Mexico," Earth Resources Operations, North American Rockwell Corporation, 1972.

23 "Electrical Resistivity Survey in Valles Caldera, New Mexico," by Group Seven, Inc., 1972.

24 "Additional Data - Electrical Resistivity Survey in the Valles Caldera, New Mexico," by Group Seven, Inc., 1972.

25 "Reconnaissance Resistivity Survey Baca Property," McPhar, 1973.

26 "Supplemental Report - Reconnaissance Resistivity and Schlumberger Depth Sounding Surveys Baca Property," McPhar, 1974.

27 "Quantitative Gravity Interpretation Valles Caldera Area, New Mexico," by R.L. Segar, 1974.

28 "Mercury Soil Gas Survey Baca Prospect," by Allied Geophysics, Ine., 1974.
APPROX. NO. PAGES

$\underline{\text { PAGE }}$

40 Text

19.0

8 Logs

20.0

APPROX. NO. PAGES PAGE

$\begin{array}{lll}56 & \text { Text } & 21.0 \\ 40 & \text { Data }\end{array}$

56 Text 22.0

28 Text

23.0

90 Data

26 Text

95 Data

7 Text

25.0

13 Text

26.0

3 Data

12 Text

27.0

20 Text

28.0 
GEOLOGY (Continued)

\begin{tabular}{|c|c|c|c|c|}
\hline REPORT & TITLE & \multicolumn{2}{|c|}{$\begin{array}{l}\text { APPRUX. } \\
\text { NO. PAGES } \\
\end{array}$} & \multirow{2}{*}{$\frac{\text { PAGE }}{29.0}$} \\
\hline 29 & "Mercury Analysis - 1974 Gradient Holes." & 2 & Data & \\
\hline 30 & $\begin{array}{l}\text { "Geothermal Geology of the Redondo Creek } \\
\text { Area Baca Location," by T.R. Slodowski, } \\
1976 .\end{array}$ & 7 & Data & 30.0 \\
\hline 31 & $\begin{array}{l}\text { "Magnetotelluric-Telluric Profile Survey," } \\
\text { Valles Caldera Prospect," by Geonomics, } \\
1976 \text {, as reprocessed by QEB, Inc., } 1978 \text {. }\end{array}$ & $\begin{array}{r}20 \\
113\end{array}$ & $\begin{array}{l}\text { Text } \\
\text { Data }\end{array}$ & 31.0 \\
\hline 32 & $\begin{array}{l}\text { "Geological Resume of the Valles Caldera," } \\
\text { by T.R. Slodowski, } 1977 .\end{array}$ & 14 & Text & 32.0 \\
\hline \multicolumn{5}{|c|}{ PRODUCTION } \\
\hline REPORT & TITLE & \multicolumn{2}{|c|}{$\begin{array}{l}\text { APPROX. } \\
\text { NO. PAGES } \\
\end{array}$} & PAGE \\
\hline 33 & $\begin{array}{l}\text { "Geothermal Power Plant Feasibility } \\
\text { Report," Rogers Engineering Company, } \\
\text { 1974. }\end{array}$ & $\begin{array}{l}66 \\
42\end{array}$ & $\begin{array}{l}\text { Text } \\
\text { Data }\end{array}$ & 33.0 \\
\hline 34 & $\begin{array}{l}\text { "Baca Well No. } 11 \text { - Scale Evaluation," } \\
\text { by Union Oil Company, Santa Rosa Dis- } \\
\text { trict, } 1975 .\end{array}$ & $\begin{array}{l}56 \\
34\end{array}$ & $\begin{array}{l}\text { Text } \\
\text { Data }\end{array}$ & 34.0 \\
\hline 35 & $\begin{array}{l}\text { "Effects of Turbine Power Cycle on } \\
\text { Development Well Requirements in Redondo } \\
\text { Creek," by J.D. Hartz, } 1977 \text {. }\end{array}$ & $\begin{array}{l}13 \\
12\end{array}$ & $\begin{array}{l}\text { Text } \\
\text { Data }\end{array}$ & 35.0 \\
\hline & \multicolumn{4}{|l|}{ RESERVOIR } \\
\hline REPORT & TITLE & \multicolumn{2}{|c|}{$\begin{array}{l}\text { APPROX. } \\
\text { NO. PAGES }\end{array}$} & PAGE \\
\hline 36 & $\begin{array}{l}\text { "Temperature Gradient Hole Data 1970, } \\
\text { 1972-1974 and Location Map." }\end{array}$ & $\begin{array}{r}68 \\
1\end{array}$ & $\begin{array}{l}\text { Data } \\
\text { Map }\end{array}$ & 36.0 \\
\hline 37 & $\begin{array}{l}\text { "Baca Project Interim Report of Test } \\
\text { Results," by A.J. Chasteen, June } 1974 \text {. }\end{array}$ & $\begin{array}{l}23 \\
38\end{array}$ & $\begin{array}{l}\text { Text } \\
\text { Data }\end{array}$ & 37.0 \\
\hline
\end{tabular}




\begin{tabular}{|c|c|c|c|c|}
\hline$\underline{\text { REPORT }}$ & TITLE & \multicolumn{2}{|c|}{$\begin{array}{l}\text { APPROX. } \\
\text { NO. PAGES } \\
\end{array}$} & \multirow{2}{*}{$\frac{\text { PAGE }}{38.0}$} \\
\hline 38 & $\begin{array}{l}\text { "Special Core Analysis Study for Union } \\
\text { Oil Company, Baca No. } 13 \text { Well, Redondo } \\
\text { Creek Field, New Mexico," Core Labora- } \\
\text { tories, Inc., } 1975 .\end{array}$ & $\begin{array}{l}3 \\
8\end{array}$ & $\begin{array}{l}\text { Text } \\
\text { Data }\end{array}$ & \\
\hline 39 & $\begin{array}{l}\text { "Baca Reservoir Studies," by M.S. Gulati, } \\
\text { August } 1975 .\end{array}$ & $\begin{array}{l}30 \\
50\end{array}$ & $\begin{array}{l}\text { Text } \\
\text { Data }\end{array}$ & 39.0 \\
\hline 40 & $\begin{array}{l}\text { "Geothermal Reservoir Evaluation of the } \\
\text { Redondo Creek Area, New Mexico," by } \\
\text { J.D. Hartz, November } 1976 \text {. }\end{array}$ & $\begin{array}{r}87 \\
114\end{array}$ & $\begin{array}{l}\text { Text } \\
\text { Data }\end{array}$ & 40.0 \\
\hline 41 & $\begin{array}{l}\text { "Baca No. 5A, Pressure Falloff and In- } \\
\text { jection," by J.D. Hartz, } 1977 .\end{array}$ & $\begin{array}{l}5 \\
2\end{array}$ & $\begin{array}{l}\text { Text } \\
\text { Data }\end{array}$ & 41.0 \\
\hline 42 & $\begin{array}{l}\text { "Baca No. 15, Production Test and } \\
\text { Reservoir Evaluation," by J.D. Hartz, } \\
1977 .\end{array}$ & $\begin{array}{l}34 \\
25\end{array}$ & $\begin{array}{l}\text { Text } \\
\text { Data }\end{array}$ & 42.0 \\
\hline \multicolumn{5}{|c|}{ MISCELLANEOUS } \\
\hline REPORT & TITLE & $\begin{array}{r}\text { APP } \\
\text { NO. } \\
\end{array}$ & $\begin{array}{l}\text { ROX. } \\
\text { AGES }\end{array}$ & PAGE \\
\hline 43 & $\begin{array}{l}\text { "Geothermal Demonstration Power Plant } \\
\text { - Project Description," Union Oil } \\
\text { Company of California and Public Service } \\
\text { Company of New Mexico. }\end{array}$ & 27 & Text & 43.0 \\
\hline 44 & $\begin{array}{l}\text { "Geothermal Demonstration Power Plant, } \\
\text { Volume I, Project Abstract." }\end{array}$ & $\begin{array}{r}37 \\
9\end{array}$ & $\begin{array}{l}\text { Text } \\
\text { Data }\end{array}$ & 44.0 \\
\hline 45 & $\begin{array}{l}\text { "Geothermal Demonstration Power Plant, } \\
\text { Volume II, Technical and Management } \\
\text { Proposal." }\end{array}$ & $\begin{array}{r}122 \\
30\end{array}$ & $\begin{array}{l}\text { Text } \\
\text { Data }\end{array}$ & 45.0 \\
\hline 46 & $\begin{array}{l}\text { "Geothermal Demonstration Power Plant, } \\
\text { Volume III, Business Proposal." }\end{array}$ & $\begin{array}{l}30 \\
11\end{array}$ & $\begin{array}{l}\text { Text } \\
\text { Data }\end{array}$ & 46.0 \\
\hline 47 & $\begin{array}{l}\text { "Geothermal Demonstration Power Plant, } \\
\text { Volume IV, Cost Proposal." }\end{array}$ & $\begin{array}{l}37 \\
89\end{array}$ & $\begin{array}{l}\text { Text } \\
\text { Data }\end{array}$ & 47.0 \\
\hline
\end{tabular}


MISCELLANEOUS (Continued)

\begin{tabular}{|c|c|c|c|c|}
\hline REPORT & TITLE & $\begin{array}{l}\text { APP } \\
\text { NO. } \\
\end{array}$ & $\begin{array}{l}\text { ROX. } \\
\text { AGES }\end{array}$ & PAGE \\
\hline 48 & $\begin{array}{l}\text { "Geothermal Demonstration Power Plant, } \\
\text { Volume V, Economics Information." }\end{array}$ & 5 & Text & 48.0 \\
\hline 49 & (No Report) & & & \\
\hline 50 & "Historical Cost Data." & 6 & Data & 50.0 \\
\hline 51 & $\begin{array}{l}\text { "Soils Information, Baca Geothermal } \\
\text { Project," provided by the U.S. Forest } \\
\text { Service, Santa Fe and Earth Environ- } \\
\text { mental Consultants, Albuerque, } 1979 .\end{array}$ & $\begin{array}{r}32 \\
2\end{array}$ & $\begin{array}{l}\text { Text } \\
\text { Data }\end{array}$ & 51.0 \\
\hline 52 & $\begin{array}{l}\text { "Transmission System Archaeological } \\
\text { Analysis, Baca Geothermal Project," } \\
\text { by Eileen Camilli, Albuquerque, New } \\
\text { Mexico, } 1979 .\end{array}$ & $\begin{array}{l}80 \\
18\end{array}$ & $\begin{array}{l}\text { Text } \\
\text { Data }\end{array}$ & 52.0 \\
\hline 53 & $\begin{array}{l}\text { "Land Use Inventory, Baca Geothermal } \\
\text { Project," by Wirth Associates, Phoenix, } \\
\text { Arizona, } 1979 .\end{array}$ & 42 & Text & 53.0 \\
\hline 54 & $\begin{array}{l}\text { "Soil Inventory, Baca Geothermal } \\
\text { Project," by L.A. Daugherty, Ph.D. and } \\
\text { B.A., Buchanan, Ph.D., Las Cruces, } \\
\text { New Mexico, } 1979 \text {. }\end{array}$ & $\begin{array}{r}117 \\
20\end{array}$ & $\begin{array}{l}\text { Text } \\
\text { Data }\end{array}$ & 54.0 \\
\hline 55 & $\begin{array}{l}\text { "Station and Well Site Archaeological } \\
\text { Analysis. An Investigation into High } \\
\text { Altitude Adaptations for the Proposed } \\
\text { Baca Geothermal Project," by the Office } \\
\text { of Contract Archaeology, University of } \\
\text { New Mexico, Albuquerque, } 1979 \text {. }\end{array}$ & $\begin{array}{r}128 \\
40\end{array}$ & $\begin{array}{l}\text { Text } \\
\text { Data }\end{array}$ & 55.0 \\
\hline 56 & $\begin{array}{l}\text { "Stream Ecology Inventory. The Biota } \\
\text { of Redondo Creek, Sandoval County, New } \\
\text { Mexico, for the Proposed Baca Geo- } \\
\text { thermal Project," by Whitford Ecological } \\
\text { Consultants, Las Cruces, New Mexico, } 1979 .\end{array}$ & $\begin{array}{l}57 \\
15\end{array}$ & $\begin{array}{l}\text { Text } \\
\text { Data }\end{array}$ & 56.0 \\
\hline 57 & $\begin{array}{l}\text { "Visual Resource Inventory for the Pro- } \\
\text { posed Baca Geothermal Project," by } \\
\text { J.M. Cantu, Environmental Affairs Depart- } \\
\text { ment, Public Service Company of New } \\
\text { Mexico, } 1979 \text {. }\end{array}$ & 35 & Text & 57.0 \\
\hline
\end{tabular}




\section{REPORT}

58

"Biotic Inventory, Baseline Information for Transmission System for the Proposed Baca Geothermal Project," by W.R. Pilz and D.G. Sabo, Environmental Affairs Department, Public Service Company of New Mexico and W.L. Wagner, Missouri Botanical Garden, St. Louis, Missouri, 1979.

59 "Socioeconomic Analysis for the Proposed Geothermal Project," by Mountain West Research, Inc., Tempe, Arizona, 1979.

60 "Public Hearing on the Environmental Impact Statement, Geothermal Demonstation Program, August 30, 1979, Transcript of Proceedings," by Howard W. Henry and Company, 1979.

61 "Final Environmental Impact Statement, Geothermal Demonstration Program, 50 MW Power Plant," by U.S. Department of Energy, January 1980.
APPROX. NO. PAGES PAGE

64 Text $\quad 58.0$

22 Data

99 Text

59.0

15 Data

288 Text 60.0

762 Text 61.0 
REPORT NO. 1

EXECUTIVE SUMMARY

\author{
PRELIMINARY INVESTIGATION \\ HYDROGEN SULFIDE BACKGROUND LEVELS \\ BACA LOCATION NO. 1, NEW MEXICO
}

FROM A REPORT

\author{
Prepared For \\ UNION GEOTHERMAL DIVISION \\ UNION OIL COMPANY OF CALIFORNIA \\ LOS ANGELES, CALIFORNIA
}

\author{
Prepared By \\ ENVIRONMENTAL SCIENCES DIVISION \\ STEARNS-ROGER INCORPORATED \\ PROJECT C-15474 \\ NOVEMBER 1974
}

Summary Prepared By

WESTEC SERVICES, InC.

ALBUQUERQUE, NEW MEXICO

MAY 1980 


\begin{abstract}
A preliminary investigation to determine background hydrogen sulfide concentrations within the Baca Location No. 1 proposed project area and to provide recommendations for further detailed and specific studies was undertaken. This preliminary study began on September 7, 1974 with the installation of a 50-site semi-quantitative hydrogen sulfide monitoring network in and about the proposed project area. For the next 50 days, each detector was read daily, recorded, and changed, as necessary. As the investigation progressed, special short-term studies were made at those locations with the highest $\mathrm{H}_{2} \mathrm{~S}$ concentrations. The field data logs of $\mathrm{H}_{2} \mathrm{~S}$ measurements for the 50-day study are attached at the end of the complete report. Conclusions were drawn based on this preliminary investigation of background ambient level hydrogen sulfide concentrations within the proposed geothermal project area. Recommendations for future studies included baseline meteorological and air quality studies, performing $\mathrm{H}_{2} \mathrm{~S}$ emission estimates from well venting, and carrying out detailed numerical $\mathrm{H}_{2} \mathrm{~S}$ impact dispersion modeling are included.
\end{abstract}


This report presents the first detailed technical investigation of the baseline levels of hydrogen sulfide $\left(\mathrm{H}_{2} \mathrm{~S}\right)$ in an around Baca Location No. 1, situated in the Jemez Mountains of north central New Mexico about 15 miles west of Los Alamos. The purpose of this preliminary study was to determine average ambient $\mathrm{H}_{2} \mathrm{~S}$ concentrations, to identify major sources and potential dispersion mechanisms and to provide recommendations for further detailed and specific studies.

Many constraints dictated that this survey be only semi-quantitative. Since exact locations of $\mathrm{H}_{2} \mathrm{~S}$ sources and magnitudes of background $\mathrm{H}_{2} \mathrm{~S}$ concentrations had not been identified, the monitoring method also required that it be operated without power, be easily serviced by one technician and yield a result that could be related to the New Mexico hourly $\mathrm{H}_{2} \mathrm{~S}$ standard of $3 \mathrm{ppb}$. The Colortec Hydrogen Sulfide Detector manufactured by Metronics Associates Incorporated was selected as a simple method of obtaining measurements of $\mathrm{H}_{2} \mathrm{~S}$ levels. The detector has a chemically treated pad which develops a brown stain when exposed to $\mathrm{H}_{2} \mathrm{~S}$. The darkness of the stain is then proportional to the $\mathrm{H}_{2} \mathrm{~S}$ dosage. Color standards representative of known dosages of $\mathrm{H}_{2} \mathrm{~S}$ are printed around the treated pad and the stain can be compared visually with the standards for immediate evaluation. By regarding (and replacing as necessary) the Colortec sampler each day, an average daily $\mathrm{H}_{2} \mathrm{~S}$ concentration was determined. Although there is no direct correlation of the hourly state air quality standard to daily average concentrations, this method provided an excellent survey tool with which later studies were structured.

Areas selected for study were based on reports of odor occurrences determined by Union Oil Co. geologists familiar with the Baca area. Most of the sites in the 50-station $\mathrm{H}_{2} \mathrm{~S}$ network were concentrated along Redondo and Sulfur Creeks where $\mathrm{H}_{2} \mathrm{~S}$ odor had previously been noted. Three sensors were located near Jemez Springs and five sensors were deployed along State Highway 4 where it crosses Baca Location No. 1 to determine existing exposure levels in areas of public access. After several weeks, four detectors were redeployed from areas where no $\mathrm{H}_{2} \mathrm{~S}$ was ever measured to several other sites along State Highway 4.

The $\mathrm{H}_{2} \mathrm{~S}$ detector network became operational on September 7, 1974 and was operated until October 26 of the same year. Each detector site was visited daily, the stain intensity of each sampler were recorded in the sampling log, and detectors were changed when necessary.

In addition to the routine monitoring program covering a larger area of potential $\mathrm{H}_{2} \mathrm{~S}$ odor impact, a small scale diffusion study was carried out at a venting well (Baca Well No. 4) for three days during the largerscale monitoring program. Fifteen detectors were used surrounding the well on a downwind are to measure dispersion factors of emissions from a single point source. 
Because of very localized sources of $\mathrm{H}_{2} \mathrm{~S}$, the ambient concentrations of $\mathrm{H}_{2} \mathrm{~S}$ showed considerable spatial variability. Within the Redondo Creek drainage, concentrations averaged over all 50 monitoring days were generally less than $3 \mathrm{ppb}$ (except at one site), with measurable $\mathrm{H}_{2} \mathrm{~S}$ levels extending from a point 2.1 miles from the State Highway 4 turnoff to the area called Upper and Lower Forks. The maximum 50 day average concentration in Redondo Creek was 3.2 ppb near a known natural seep between Baca Wells No. 6 and No. 11 . Within the Sulfur Creek drainage, $\mathrm{H}_{2} \mathrm{~S}$ concentrations were much higher. Fiftyday average concentrations near Sulfur Springs were over $100 \mathrm{ppb}$ with considerable dead plantlife on the hillside where the maximum concentration was observed. All monitoring sites along State Highway 4 except one location near Battleship Rock showed zero concentrations. Dispersion of $\mathrm{H}_{2} \mathrm{~S}$ emissions from natural sources and from isolated leaking or venting wells appeared to be sufficient in areas of public access, to avoid exceedances of the standard with the exception of areas very close to any direct $\mathrm{H}_{2} \mathrm{~S}$ sources.

Monitoring activities around well areas in Redondo Creek showed little difference in $\mathrm{H}_{2} \mathrm{~S}$ levels when compared to nearby areas of natural seepage except during periods of continuous atmospheric venting of the wells. During the direct venting of Baca Well No. 4, $15 \mathrm{H}_{2} \mathrm{~S}$ detectors were deployed around the well site. Short period analysis of the detector color stains suggested a dilution factor of 100 within 5 feet of the source and a factor of 16,000 within 25 feet of the source. The preparers of this report concluded that "the atmosphere is an excellent dispersive medium for $\mathrm{H}_{2} \mathrm{~S} . "$

The $\mathrm{H}_{2} \mathrm{~S}$ data also showed a strong negative correlation with rainfall, particularly in areas of natural seepage. Periods of rain corresponded to low ambient $\mathrm{H}_{2} \mathrm{~S}$ levels. The authors concluded that "the rain is either purging the $\mathrm{H}_{2} \mathrm{~S}$ from the air or the increased soil moisture content is preventing $\mathrm{H}_{2} \mathrm{~S}$ seepage."

The overall conclusions from this preliminary monitoring program, as stated by Stearns-Roger Environmental Sciences Division authors, are as follows:

1. Natural $\mathrm{H}_{2} \mathrm{~S}$ seepage along the upper portions of Redondo Creek approaches the 1971 New Mexico Standard (3 ppbv) on the average and can exceed the standard on any given day. Natural $\mathrm{H}_{2} \mathrm{~S}$ seepage along Sulfur Creek routinely exceeds the applicable standard by an order of magnitude and can, at times, approach two orders of magnitude. Natural seepage along the Jemez River Canyon does, on occasion, exceed the standard. No natural seepage was recorded along State Highway 4, where it crosses Baca property, or along State Highway 126 to the west. 
2. Venting of steam to the air at Redondo Creek resulted in ambient level $\mathrm{H}_{2} \mathrm{~S}$ concentrations comparable to and indistinguishable from the natural background levels.

3. Leaking exploration wells can provide an emission source of several hundred parts per million of dry $\mathrm{H}_{2} \mathrm{~S}$. With proper precautions, capped exploration wells did not contribute significant amounts of $\mathrm{H}_{2} \mathrm{~S}$ to the natural background.

4. The atmosphere is an excellent dispersive medium for $\mathrm{H}_{2} \mathrm{~S}$ resulting in a 16,000-fold dilution within 25 feet downwind of an emission source. Thus, measurements of ambient-level $\mathrm{H}_{2} \mathrm{~S}$ concentrations are very dependent upon exact sensor location in relation to the $\mathrm{H}_{2} \mathrm{~S}$ source.

5. The occurrence of rain lowers ambient concentrations of $\mathrm{H}_{2} \mathrm{~S}$.

In addition to providing some initial information on baseline $\mathrm{H}_{2} \mathrm{~S}$ concentrations in Baca Location No. 1, this study helped to define the structure of future investigations. Recommendations for future studies included:

1. Baseline meteorological studies using portable mechanical weather stations, a 60-meter meteorological tower, precipitation gauges and an upper air monitoring program of passive weather balloons and twice-per-day radiosonde observations.

2. Baseline air quality studies continuing the Colortec $\mathrm{H}_{2} \mathrm{~S}$ analysis and the eventual installation of continuous analyzers for $\mathrm{H}_{2} \mathrm{~S} / \mathrm{SO}_{2}$, $\mathrm{NO} / \mathrm{NO}_{2} / \mathrm{NO}_{\mathrm{X}}$ and particulates.

3. Emission estimates from well venting and periodic analyses of trace elements in the venting steam.

4. Dispersion modeling using Gaussian point-source dispersion models using the Stearns-Roger IBM 370/15B computer.

A number of these recommendations were subsequently funded and are reported in later Stearns-Roger progress reports. 
Title

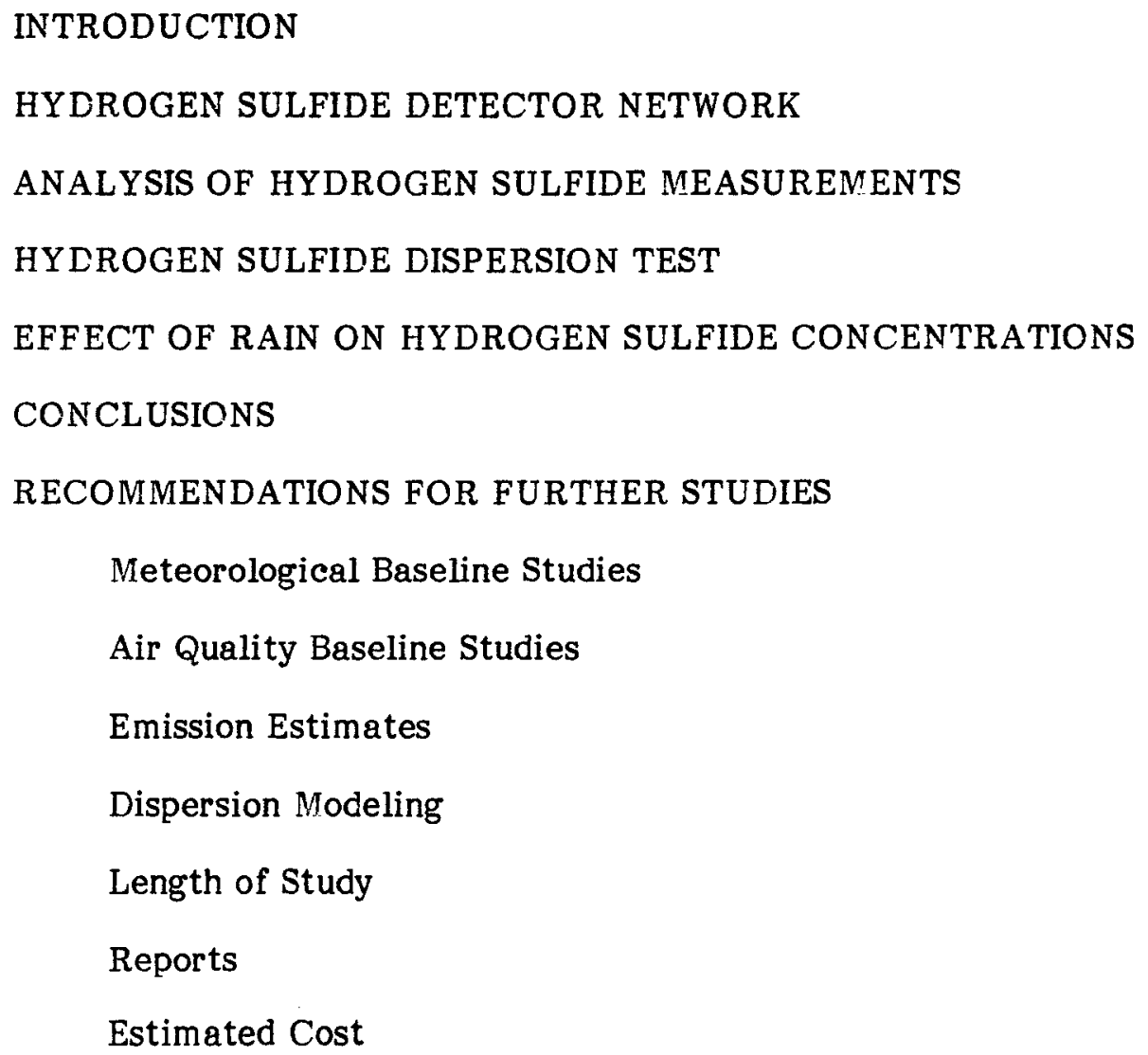


REPORT NO. 2

EXECUTIVE SUMMARY

SECOND PROGRESS REPORT

METEOROLOGICAL AND HYDROGEN SULFIDE

BACKGROUND OBSERVATIONS

BACA LOCATION NO. 1, NEW MEXICO

FROM A REPORT

\author{
Prepared For \\ UNION GEOTHERMAL DIVISION \\ UNION OIL COMPANY OF CALIFORNIA \\ LOS ANGELES, CALIFORNIA
}

\author{
Prepared By \\ ENVIRONMENTAL SCIENCES DIVISION \\ STEARNS-ROGER INCORPORATED \\ PROJECT C-15474 \\ JUNE 1975
}

Summary Prepared By

WESTEC SERVICES, Inc.

ALBUQUERQUE, NEW MEXICO

MAY 1980 


\begin{abstract}
This study represents a second investigation to determine background hydrogen sulfide concentrations within the Baca Location No. 1 proposed project area and covers a fourth-month period beginning in January 1975.

Four portable weather stations for measuring wind speed, wind direction, and temperature were installed along Redondo Creek, in the area of major geothermal well drilling, along with a hygrothermograph and heated precipitation gauge at the Union Oil office. A 24-site hydrogen sulfide detector network was also established in the same area. Continuous measurements were recorded by the meteorological stations for the fourth-month period while three 24-hour hydrogen sulfide concentration observations were taken at the 24 sites each month between January and May. The monitoring program described in this report was continued through 1975 with some modifications and is documented in three subsequent progress reports.
\end{abstract}




\subsection{INTRODUCTION AND SCOPE}

A preliminary survey of the spatial distribution of hydrogen sulfide $\left(\mathrm{H}_{2} \mathrm{~S}\right)$ in the Baca Location No. 1 yielded some very instructive data on baseline $\mathrm{H}_{2} \mathrm{~S}$ levels. It was decided to continue the routine $\mathrm{H}_{2} \mathrm{~S}$ sampling program and to deploy meteorological monitoring equipment to correlate air quality and weather data. Because of winter access problems this study was confined to the Redondo Creek drainage except for one $\mathrm{H}_{2} \mathrm{~S}$ monitoring station near Jemez Springs.

The winter monitoring program began in early January 1975, and continued until early May of the same year. The meteorological monitoring consisted of four portable weather stations for measuring wind speed, wind direction, and temperature which were installed along Redondo Creek, in the area of major geothermal well drilling, along with a hygrothermograph and heated precipitation gauge at the Union Oil office.

The mechanical weather stations (MWS) are self-contained and require only monthly chart changes. They were mounted on 10-foot tripods inside a fenced enclosure. One weather station was deployed near Baca Well No. 6 with two stations upstream at Upper and Lower Forks and one station downstream in a large open area called Henry's Meadow. Unfortunately, the low tripod and rising snow level during the winter may have somewhat distorted the mean wind distribution because of surface frictional effects, but the data do provide a meaningful characterization of the principal Baca area windflows.

Concurrently with the meteorological data program, a 24-site hydrogen sulfide detector network was also established in the same area. The $\mathrm{H}_{2} \mathrm{~S}$ network employed the same $\mathrm{H}_{2} \mathrm{~S}$-sensitive chemically treated paper samplers (Colortec samplers from Metronics Associates) as in the initial survey. Where possible, the same sites used in the fall of 1974 were used in the winter to examine seasonal variations in the $\mathrm{H}_{2} \mathrm{~S}$ concentrations. Baseline $\mathrm{H}_{2} \mathrm{~S}$ sampling was intermittent, with three 24-hour hydrogen sulfide concentration observations taken at the 24 sites each month between January and May.

\subsection{SUMMARY AND CONCLUSIONS}

For those weather stations that were readily accessible, (Henry's Meadow and Baca Well No. 6) data recovery exceeded 95 percent. For the two stations at Upper and Lower Forks that could not be visited except by snowmobile or on snowshoes, problems with frozen chartdrive gears reduced data recovery to less than 50 percent at Upper Forks and less than 70 percent at Lower Forks.

The wind monitoring network produced results generally expected in channeled complex terrain airflow. Winds below the treeline in canyon environments have upslope winds by day, downslope winds at night and 
display an unusually high frequency of calm winds. Winds at Baca Well No. 6 were upslope from the south-southwest by day and downslope from the north-nor theast at night. The average wind speed was $3.2 \mathrm{mph}$ with 42.6 percent of all observations reported as calm $(\leq 2 \mathrm{mph})$. The Meadow site had a more open exposure to the west with somewhat higher windspeeds of $4.3 \mathrm{mph}$ and 38.4 percent calms. Daytime winds were upslope from the west and nighttime winds drained from both Redondo Creek and Banco Bonito across the Meadow. Wind data at the upper sites showed the daytime upslope from the southwest, but also experienced some funneling of the prevailing westerlies aloft through the passes on which the upper stations were located. Since these stations are at the top of the cold air nocturnal drainage pattern, their winds were often calm with calms present on over 50 percent of all observations at both sites.

Temperature data indicated probable strong nocturnal temperature inversions within Redondo Creek. Minimum nighttime and maximum daytime temperatures were observed at the Meadows station with much smaller temperature oscillations at the higher elevation stations. Such strong inversions and calm winds suggested considerable potential for nocturnal air pollutant stagnation close to any low-level $\mathrm{H}_{2} \mathrm{~S}$ sources.

$\mathrm{H}_{2} \mathrm{~S}$ concentrations for the three days per month of monitoring were similar to the fall study except for considerably higher average concentrations. Snow cover did not suppress natural $\mathrm{H}_{2} \mathrm{~S}$ emissions as had been anticipated. Average $\mathrm{H}_{2} \mathrm{~S}$ concentrations for all monitoring days in the area where high $\mathrm{H}_{2} \mathrm{~S}$ levels from natural emissions had been observed during the fall were about three times higher in the winter. Maximum background concentrations of $19.3 \mathrm{ppb}$ for all days and a 24-hour maximum of $65 \mathrm{ppb}$ were far in excess of the New Mexico hourly standard of $3 \mathrm{ppb}$. The presence or absence of snow cover did not appear to affect daily average concentrations; the winter rise in $\mathrm{H}_{2} \mathrm{~S}$ concentrations was apparently correlated more to diminished dispersive capacity.

The recommendations following this study paralleled the recommendations of the first Stearns-Roger report for continuing the ongoing meteorology and air quality program and initiating preliminary upper air observations and dispersion modeling programs. These recommendations were adopted and results are detailed in the three subsequent technical reports. 
TABLE OF CONTENTS FOR THE COMPLETE REPORT

Title

Page

SUMMARY, CONCLUSIONS AND RECOMMENDATIONS

AMBIENT-LEVEL HYDROGEN SULFIDE OBSERVATIONS

Hydrogen Sulfide Detector

Detector Network

Hydrogen Sulfide Concentrations

Analysis of Results

METEOROLOGICAL PROGRAM

Instrumentation

Monitoring Network

Observations

Analysis of Results

21

\section{APPENDIX}

Section 1 - Hydrogen Sulfide Observation Logs

Section 2 - Hourly Meteorological Observations 
REPORT NO. 3

EXECUTIVE SUMMARY

THIRD PROGRESS REPORT

METEOROLOGICAL AND HYDROGEN SULFIDE

MONITORING PROGRAMS

BACA LOCATION NO. 1, NEW MEXICO

FROM A REPORT

\author{
Prepared For \\ UNION GEOTHERMAL DIVISION \\ UNION OIL COMPANY OF CALIFORNIA \\ LOS ANGELES, CALIFORNIA
}

\author{
Prepared By \\ ENVIRONMENTAL SCIENCES DIVISION \\ STEARNS-ROGER INCORPORATED \\ PROJECT C-15474 \\ OCTOBER 1974
}

Summary Prepared By

WESTEC SERVICES, Inc.

ALBUQUERQUE, NEW MEXICO

MAY 1980 


\begin{abstract}
This is the third in a series of investigative reports to determine background hydrogen sulfide concentrations within the Baca Location No. 1 proposed project area. This study covers the five-month period through September 1975 and summarizes all data collected to that date.

Monitoring activities reported in this document include a continuation of the mechanical weather station network, an upgrading of the 24-station $\mathrm{H}_{2} \mathrm{~S}$ measurement program to ten samples per month, the addition of a periodic upper air wind and temperature program, and periodic suspended particulate monitoring using hi-volume dust samplers.

The Third Progress Report provides a tabulation of observations and analyses for data collected between May and September 1975, summarizes all information through September 1975 and includes the first upper-air study.
\end{abstract}


During late spring, summer and early fall of 1975, the baseline hydrogen sulfide $\left(\mathrm{H}_{2} \mathrm{~S}\right)$ and meteorological monitoring program begun in the fall of 1974 and expanded during the winter of 1975 was continued on a regularly scheduled basis. The monitoring system in May 1975 consisted of four self-contained, battery powered mechanical weather stations (MWS) at locations identified as Upper Forks, Lower Forks, Baca Wells (Baca Well No. 6) and the Meadows (Henry's Meadow). In addition, a hygrothermograph and heated precipitation gauge was operated at the Union Oil Co. Geothermal Division office trailer. $\mathrm{H}_{2} \mathrm{~S}$ monitoring consisted of long-period exposure chemically treated paper tabs that develop a characteristic stain color as a function of cumulative $\mathrm{H}_{2} \mathrm{~S}$ exposure. The weather stations were visited twice per month and the $\mathrm{H}_{2} \mathrm{~S}$ network was operated for three days each month.

As site access became easier during the early summer of 1975 following the melting snow, the three monthly $\mathrm{H}_{2} \mathrm{~S}$ readings were expanded to ten per month. In addition, an intermittent upper air monitoring program and a hi-volume dust monitoring program were included in the program scope beginning in August and September of 1975, respectively. The upper air program was an eight-day field campaign conducted onsite in August 1975 by Colorado International Corporation. During these upper-air studies, six weather balloons were released daily. Two of the daily balloon releases carried radiosonde transmitters to measure temperatures aloft to determine frequency of occurrence and heights of temperature inversion layers, which are extremely important in assessing the atmospheric dispersion potential in the project area.

Dust monitoring was initiated early in September 1975. Twenty-four hour total suspended particulate (TSP) monitoring was scheduled for ten days during the $\mathrm{H}_{2} \mathrm{~S}$ sampling program and on an every 6 th day schedule during non $-\mathrm{H}_{2} \mathrm{~S}$ measurement periods at the Union trailer headquarters.

Levels of hydrogen sulfide in the Redondo Creek drainage varied from $0.0 \mathrm{ppb}$ to complete saturation of the Colortec detectors $(>180 \mathrm{ppb})$. Distance from $\mathrm{H}_{2} \mathrm{~S}$ sources (whether natural seeps or geothermal wells) and configuration of each well (whether capped, leaking or vented) appeared to be the major factors in governing ambient $\mathrm{H}_{2} \mathrm{~S}$ concentrations.

Time of day played an important part in concentration levels as the wind would change directions in early morning and late evening. No detectable concentrations were observed in eight of the monitoring stations during the nine months even after 30-day exposures, indicating average $\mathrm{H}_{2} \mathrm{~S}$ concentrations less than $0.04 \mathrm{ppb}$. Except for one location near Baca Well No. 4 which had a leaky casing, there was no $\mathrm{H}_{2} \mathrm{~S}$ observed upstream of Baca Well No. 13 or along the road toward Baca 
Well No. 4. Downstream concentrations dropped to zero near Baca Well No. 12, with no $\mathrm{H}_{2} \mathrm{~S}$ observed beyond that point anywhere along the road to State Highway 4.

From the recorded observations, there does not appear to be a seasonal trend in concentrations. The variations were very localized with large day-to-day changes. There was a tendency for the concentrations at the stations along the Redondo Creek fault to rise and fall in cycle with each other with trends to indicate a common cause - possibly meteorological conditions or out-gassing along the fault.

Gaussian diffusion models predict that pollution concentration is inversely proportional to wind speed, i.e., low winds cause high concentrations, and vice versa. To evaluate how the $\mathrm{H}_{2} \mathrm{~S}$ monitoring data obeyed this relationship, a correlation plot between wind data near Baca Well No. 11 and nearby $\mathrm{H}_{2} \mathrm{~S}$ data was performed. The correlation was poor with a slight positive correlation (higher $\mathrm{H}_{2} \mathrm{~S}$ with higher wind speeds) rather than a negative correlation. No plausible explanation for the failure of the data to obey classical diffusion laws could be offered.

Surface meteorological observations at the weather stations at Upper and Lower Forks, near Baca Well No. 6, in Henry's Meadow, and at the Union headquarters trailer showed a continuing pattern of upslope/downslope winds, a high frequency of calm winds, warmer temperatures in lower elevations, except when very cold air pools in the valley at night, with patterns dominated almost completely by local topography instead of any broadscale general circulation.

An eight-day upper-air field campaign was conducted by Colorado International Corporation, under the direction of Ralph Papania, Certified Consulting Meteorologist, at the Meadow Station during the period August 16 through 23. Wind direction and speed observations were made six times per day. At the surface, the prevailing south-southwest through west-northwest daytime upslope winds were seen along with the nighttime northeasterly drainage winds. This same pattern had been recorded by the weather station at this site. As altitude increases, the prevailing winds gradually shifted to west and westnorthwest at the higher levels.

In the lower atmosphere, wind speeds normally increase with height approximated by a power low relationship:

$$
\mathrm{S}_{2}=\mathrm{s}_{1}\left(\frac{\mathrm{H}_{2}}{\overline{\mathrm{H}}_{1}}\right)^{\mathrm{r}}
$$

where

$$
\begin{aligned}
& \mathrm{S}_{2}=\text { wind speed at height, } \mathrm{H}_{2} \text { in } \mathrm{m} / \mathrm{sec} \\
& \mathrm{S}_{1}=\text { wind speed at height, } \mathrm{H}_{1}\left(\mathrm{H}_{2}>\mathrm{H}_{1}\right) \text { in } \mathrm{m} / \mathrm{sec} \\
& \mathrm{r}=\text { dimensionless exponent }
\end{aligned}
$$


In prior studies over flat terrain, "r" has averagéd around 0.14 ("oneseventh power law").

Upon analyzing the upper air wind data from the 8-day study, " $r$ " was found to be greater than 0.14 , indicating that the increase of wind speed with height is greater at this location. This was to be expected in this mountainous region where the low-level winds are sheltered by the surrounding terrain. The strongest winds aloft are associated with cold front passages.

Temperature and humidity soundings were made twice per day, near sunrise and again during the middle of the afternoon. The early morning soundings were made shortly after sunrise when the surfacebased, radiative-cooling temperature inversion should be at its strongest. There was a very strong inversion in the lowest 500 feet with a weaker inversion extending to 1000 feet above gound level. Above 1000 feet, the temperature decreased with height. Each of the individual early morning soundings showed this surface-based inversion. The frequency of occurrence and height of these inversion layers are extremely important in estimating the pollutant dispersion potential in the proposed development area.

The average mid-afternoon temperature sounding revealed a superadiabatic lapse rate (indicative of atmospheric instability) between the surface and 3500 feet and again between 4500 and 5000 feet. This unstable air during the day should lead to excellent dispersion conditions.

Particulate observations taken during September of 1975 indicated that the maximum recorded 24-hour suspended particulate concentration during these first six samples was $100 \mu \mathrm{g} / \mathrm{m}^{3}$ which is 67 percent of the secondary National Ambient Air Quality Standard (NAAQS) of $150 \mu \mathrm{g} / \mathrm{m}^{3}$. The geometric mean of the six samples was $16.0 \mu \mathrm{g} / \mathrm{m}^{3}$ which is 27 percent of the secondary annual NAAQS of $60 \mu \mathrm{g} / \mathrm{m}^{3}$. In the semiarid regions of the west, the secondary NAAQS for suspended particulates can be exceeded on occasions due to naturally occurring windblown dust. The concentration values are expected to be lower during the winter, when the ground is snow covered, and higher during the summer when particulate concentrations will be very dependent upon the amount of rainfall that is received. 
TABLE OF CONTENTS FOR THE COMPLETE REPORT

Title

Page

SUMMARY

1

HYDROGEN SULFIDE OBSERVATIONS

1. Monitoring Network 4

2. Hydrogen Sulfide Concentrations $\quad 7$

METEOROLOGICAL OBSERVATIONS

$\begin{array}{ll}\text { 1. Monitoring Network } & 15\end{array}$

2. Surface Observations 16

a. Baca Wells Station 16

b. Meadow Station 33

c. Lower Forks Station 46

d. Upper Forks Station $\quad 58$

e. Site 3 Station $\quad 62$

SUSPENDED PARTICULATES

APPENDIX

Section 1 - Hydrogen Sulfide Observation Logs, June through September 1975

Section 2 - Hourly Meteorological Observations, May through August 1975

Section 3 - Upper-Air Observation Logs 
REPORT NO. 4

EXECUTIVE SUMMARY

\author{
PRELIMINARY \\ GROUND-LEVEL HYDROGEN SULFIDE \\ CONCENTRATION ESTIMATES \\ BACA LOCATION NO. 1, NEW MEXICO
}

FROM A REPORT

\author{
Prepared For \\ UNION GEOTHERMAL DIVISION \\ UNION OIL COMPANY OF CALIFORNIA \\ LOS ANGELES, CALIFORNIA
}

\author{
Prepared By \\ ENVIRONMENTAL SCIENCES DIVISION \\ STEARNS-ROGER INCORPORATED \\ PROJECT C-15474 \\ DECEMBER 1975
}

Summary Prepared By

WESTEC SERVICES, Inc.

ALBUQUERQUE, NEW MEXICO

MAY 1980 


\begin{abstract}
This document is the fourth in a series of reports aimed at determining levels of ambient hydrogen sulfide in the atmosphere within the Baca Location No. 1 proposed project area. Prior reports, dated November 1974, June 1975 and October 1975 , dealt with measured background levels of hydrogen sulfide and documented actual atmospheric conditions at the proposed project site. This report documents calculated levels of hydrogen sulfide due to both assumed emission levels from the proposed project in addition to background hydrogen sulfide. Parameters considered are: stack height, emission concentration, and a variety of atmospheric factors. The calculations resulted in the conclusion that contributions to ambient hydrogen sulfide due to the project will be considerably lower than the existing background levels due to natural sources. Concentrations added by the project outside of property boundaries will be insignificant compared with existing natural background.
\end{abstract}


$1.0 \quad$ INTRODUCTION AND SCOPE

After approximately one year of baseline hydrogen sulfide concentrations had been measured in the Redondo Creek area, sufficient data were available for a comparison with probable levels of $\mathrm{H}_{2} \mathrm{~S}$ resulting from proposed geothermal development in Baca Location No. 1. Although estimating diffusion in complex terrain is very imprecise, simple dispersion calculation methodologies allow at least an order of magnitude estimate of ambient air quality impacts from project-related $\mathrm{H}_{2} \mathrm{~S}$ emissions.

Ground-level hydrogen sulfide concentration estimates were computed using the dispersion model developed by D.B. Turner (1970) for the Environmental Protection Agency as published in the "Workbook of Atmospheric Dispersion Estimates." This workbook presents methods of practical application of the binormal (Gaussian) continuous plume dispersion model to estimate concentrations of air pollutants.

Hydrogen sulfide was assumed to be emitted at a rate of 50 pounds per hour $(6.3 \mathrm{~g} / \mathrm{sec})$. Since the computed concentrations are directly proportional to the pollutant emission rate, the calculated concentrations can be linearly scaled for other emission rates. The location of the proposed plant site was assumed to be near the headwaters of Redondo Creek at a location called Upper Forks at an elevation of 9400 feet. The concentration estimates were computed for emission heights of $15,30,60,120$, and 200 meters above the surface.

Wind speed, wind direction, and temperature had been recorded continuously at Upper Forks since January 1975. This site is located in a saddle between Redondo Border, to the northwest, and Redondo Peak, to the southeast. Lower elevations are to the southwest and northeast. There is one prevailing wind direction at this location -- southsouthwest.

The entire spectrum of meteorological input conditions was considered for analysis with the Gaussian model. Possible input conditions included stable conditions with strong temperature inversions, neutral conditions with well-mixed air and unstable conditions that cause rapid mixing of buoyant emissions. However, the upper air monitoring program at the large meadow (Henry's Meadow) along the access road to the possible plant site had shown the nocturnal inversion tops to be near 9200 feet. With a plant site of 9400 feet and a warm, moist plume rising several hundred feet higher due to buoyance, such plumes would not be trapped by temperature inversions in Redondo Creek. Based on these considerations, neutral and unstable conditions were selected for analysis. The conditions investigated were:

Stability Class A (extremely unstable), wind speed $=2 \mathrm{~m} / \mathrm{sec}$

Stability Class B (unstable), wind speed $=3 \mathrm{~m} / \mathrm{sec}$ 
Stability Class C (slightly unstable), wind speed $=4 \mathrm{~m} / \mathrm{sec}$

Stability Class D (neutral), wind speed $=5 \mathrm{~m} / \mathrm{sec}$

Wind direction was held constant from the south-southwest.

Background hydrogen sulfide was estimated from actual background measurements reported in previous studies, but since the location and release heights of background emissions and the proposed power plant did not coincide, no superposition of background and plant emissions was attempted.

\section{SUMMARY AND CONCLUSIONS}

The highest estimated one-hour ground-level $\mathrm{H}_{2} \mathrm{~S}$ concentration, within the property boundary, of $82.6 \mathrm{ppbv}$ (parts per billion by volume), occurred with a 15 -meter stack at 0.3 miles downwind. Redondo Creek is in an area of naturally occurring geothermal activity where $\mathrm{H}_{2} \mathrm{~S}$ is one of the main pollutant emissions. Naturally occurring ambient $\mathrm{H}_{2} \mathrm{~S}$ concentrations as high as $65 \mathrm{ppbv}$ for a 24-hour average have been observed along a fault line in the upper portion of Redondo Creek Canyon. By applying a time-scaling correction factor to the 24-hour observation as suggested in Turner's Workbook, the predicted hourly concentration is $176 \mathrm{ppbv}$. Thus, the projected maximum concentrations from the proposed power plant, even with the shortest stack, are only about half of the existing natural background. Off of the property, the estimated one-hour $\mathrm{H}_{2} \mathrm{~S}$ concentrations from the project are considerably less than 3 ppbv. In nearby areas with public access, one-hour naturally occurring $\mathrm{H}_{2} \mathrm{~S}$ concentrations as high as $400 \mathrm{ppbv}$ have been measured along Sulfur Creek (hot sulfur springs) and about 20 ppbv along State Highway 4 near the Battleship Rock picnic area near Jemez Springs.

In summary, ambient concentrations of $\mathrm{H}_{2} \mathrm{~S}$ added by the project within property boundaries will be considerably lower than the existing background levels which are already present due to natural sources. Concentrations added by the project outside of property boundaries will be insignificant compared with existing natural background. 
INTRODUCTORY LETTER

DISPERSON MODEL

PLUME RISE EQUATION

ENGINEERING INPUT DATA

METEOROLOGICAL INPUT DATA

3

GROUND-LEVEL HYDROGEN SULFIDE CONCENTRATION ESTIMATES

5

ANALYSIS OF RESULTS

6

REFERENCES 
REPORT NO. 5

EXECUTIVE SUMMARY

\author{
ANNUAL REPORT \\ METEOROLOGICAL AND AIR QUALITY \\ MONITORING PROGRAMS
}

BACA LOCATION NO. 1, NEW MEXICO

\title{
FROM A REPORT
}

\author{
Prepared For \\ UNION GEOTHERMAL DIVISION \\ UNION OIL COMPANY OF CALIFORNIA \\ LOS ANGELES, CALIFORNIA
}

\author{
Prepared By \\ ENVIRONMENTAL SCIENCES DIVISION \\ STEARNS-ROGER INCORPORATED \\ PROJECT C-15474 \\ FEBRUARY 1976
}

Summary Prepared By

WESTEC SERVICES, Inc.

ALBUQUERQUE; NEW MEXICO

MAY 1980 


\begin{abstract}
A preliminary investigation to determine background hydrogen sulfide concentrations within the Baca Location No. 1 proposed project area and to provide recommendations for further detailed and specific studies was undertaken. This preliminary study began on September 7, 1974 with the installation of a 50-site semi-quantitative hydrogen sulfide monitoring network in and about the proposed project area. As a result of this preliminary investigation, a 24-site hydrogen sulfide detector network was established along Redondo Creek to further the investigation. Four meteorological stations, a hygrothermograph and heated precipitation gauge were put into operation between October 1974 and January 1975 along the length of the area of major geothermal drilling activity. Continuous measurements were recorded by these meteorological stations through November 1975. A high-volume sampler for measuring suspended particulate concentrations was installed at Redondo Creek in September 1975. In addition, two eight-day upper-air field campaigns were conducted onsite in August and November 1975.

The Annual Report presents observational summaries and analyses of the meteorological and air quality data collected from September 1974 through November 1975. Using the onsite surface and upper-air meteorological observations along with preliminary engineering design information for the proposed project, hydrogen sulfide concentration estimates due to the planned project were calculated using dispersion models developed by the Environmental Protection Agency.

This report summarizes all materials detailed in four previous Stearns-Roger technical reports, updates the results of ongoing air quality and meteorology programs and presents some additional modeling results. Much of the material in this volume, including text, figures and tables, has appeared in the previous four reports.
\end{abstract}




\section{$1.0 \quad$ INTRODUCTION AND SCOPE}

The Union Geothermal Division, Union Oil Company of California, is participating in commercial development of geothermal energy at Baca Location No. 1, located near Redondo Peak in the Jemez Mountains of north-central New Mexico about 15 airline miles west of Los Alamos.

In this region, as in most areas of geothermal activity, natural gaseous sulfur compounds, with their pungent and acrid odors, are being emitted. One of the most common of these compounds is hydrogen sulfide, identified by its malodorous rotten- egg smell. Stearns-Roger Incorporated was employed to undertake a preliminary investigation to determine background hydrogen sulfide concentrations within the project area and to provide recommendations for further detailed and specific studies. This preliminary study began on September 7, 1974 with the installation of a 50-site semi- quantitative hydrogen sulfide monitoring network in and about the proposed project area. For the next 50 days, daily hydrogen sulfide background concentrations were measured at each of the 50 sites.

After discussion of the results of this preliminary investigation among environmental scientists at Union Oil and Stearns-Roger, it was mutually agreed that further study was warranted. A 24-site hydrogen sulfide detector network was established along Redondo Creek. For the first six months of 1975, three 24-hour concentration observations were made monthly at each of the 24 sites. Starting in July 1975 and continuing for five months through November 1975, the frequency of these measurements was increased to ten 24-hour observations each month at each of the 24 sites.

To determine windflow patterns in this area with its rugged terrain along with other meteorological parameters, a portable weather station to measure wind direction, wind speed, and temperature was installed along Redondo Creek in October 1974. Three additional meteorological stations were put into operation along the length of the area of major geothermal drilling activity in January 1975. A hygrothermograph and heated precipitation gauge were installed at the Union Oil office the same month. Continuous measurements were recorded by these meteorological stations through November 1975.

A high-volume sampler for measuring suspended particulate concentrations was installed at Redondo Creek in September 1975. During the period September through November 1975, ten consecutive 24-hour samples were collected each month with the high-volume sampler during visits by Stearns-Roger personnel. During the remainder of the three months, 24-hour samples were taken every sixth day (to conform to the National schedule) by Union Oil personnel. Composites of the samples from the high-volume filters were analyzed spectrographically for trace elements. 
Two eight-day upper-air field campaigns were conducted onsite in August and November 1975 by Colorado International Corporation under the direction of Ralph Papania, Certified Consulting Meteorologist. During each of these eight-day studies, six weather balloons were released daily and tracked by the double-theodolite method to determine wind speed and direction from the surface to 5000 feet above ground level. Two of the daily balloon releases carried radiosonde transmitters for simultaneous measurements of temperatures aloft to determine frequency of occurrence and heights of inversion layers.

\subsection{SUMMARY AND CONCLUSIONS}

The Annual Report presents observational summaries and analyses of all meteorological and air quality data collected from September 1974 through November 1975. Details of many of the observational programs and special studies have been described by Stearns-Roger in the previous progress reports. Although most previously submitted materials are again included in this report, only the general findings and any significantly new materials will be discussed in this summary.

The air quality $\left(\mathrm{H}_{2} \mathrm{~S}\right)$ monitoring program revealed that naturally occurring hydrogen sulfide ambient concentrations along the hot sulfur springs resorts at Sulfur Creek were 100 times higher than the 1974 New Mexico one-hour standard of 3 ppbv (parts per billion by volume) and background concentrations 40 times larger than the standard were observed along Redondo Creek in the area of the current geothermal energy development.

Meteorological measurements defined a very pronounced pattern of upslope/downslope day/night motion with extremely light winds below the frost canopy. Winds in the upper portion of Redondo Creek were upslope by day, but had no organized motion at night. Warmest daytime and coldest nighttime temperatures occurred along the valley floor with smaller temperature oscillations at higher altitudes. The upper air program showed that nocturnal radiation inversions were about 1000 feet deep above the valley floor with rapid dissipation of such inversions after sunrise. Wind speeds increased rapidly aloft with wind directions predominantly out of the northwest above the sheltering effects of local terrain.

Numerous problems with instrument malfunctions demonstrated the need to constantly monitor and maintain equipment in the harsh mountainous environment. Data losses were experienced from two weather stations, the hygrothermograph and the precipitation gauge because the clocks failed, gears froze, etc.

Particulate monitoring, despite the heavy dust emissions from local dirt roads, showed no exceedances of the federal primary or secondary suspended particulate standard. Twenty-four hour particulate concentrations ranged from values cleaner than the supposed global background dust level to 109.6 micrograms per cubic meter (compared to 
the national secondary clean air standard of $\left.150 \mu \mathrm{g} / \mathrm{m}^{3}\right)$. The mean concentration of 30 dust observations was about two-thirds of the annual secondary particulate standard. Assuming particulate levels are lower in winter and spring when soils are snow-covered or damp, the area appears to be an attainment area for particulate standards.

Preliminary calculations using a Gaussian point source diffusion model had shown that a geothermal power plant constructed near the headwaters of Redondo Creek would not cause ambient $\mathrm{H}_{2} \mathrm{~S}$ standards to be violated outside the Baca property boundary. Other possible plant sites and other meteorological input conditions were used to further define the range of potential project impacts. Candidate plant sites were chosen at each site where wind data were available and more restrictive, worst-case input conditions were used for modeling analysis.

Assuming an $\mathrm{H}_{2} \mathrm{~S}$ emission rate of 50 pounds per hour released from a 50-foot stack, the following conclusions were drawn:

1. Outside of the property boundaries of Baca Location No. 1, where the $1974 \mathrm{New}$ Mexico one-hour ambient $\mathrm{H}_{2} \mathrm{~S}$ standard was applied, ambient $\mathrm{H}_{2} \mathrm{~S}$ concentrations (either at ground level or along the canyon walls) from the proposed four possible plant locations would all be within the standard.

2. Within property boundaries, the lowest concentrations occurred with sites located at Upper Forks and Lower Forks. The maximum estimated concentration from these two locations was $8.2 \mathrm{ppbv}$ which is an order of magnitude less than the naturally occurring background $\mathrm{H}_{2} \mathrm{~S}$ concentrations already present in the area. The highest concentrations were estimated to occur with a plant located at Baca Wells in Redondo Creek Valley. The maximum computed value of $400 \mathrm{ppbv}$ at this location is about thrice the observed background $\mathrm{H}_{2} \mathrm{~S}$ levels. The estimated maximum concentrations from a plant located in the Meadow were about the same as the natural background. 
TABLE OF CONTENTS FOR THE COMPLETE REPORT

Section

$\underline{\text { Title }}$

Page

SUMMARY

METEOROLOGICAL OBSERVATIONS 4

Monitoring Network 4

Instrument Specifications $\quad 4$

Surface Observations $\quad 8$

$\begin{array}{ll}\text { Upper-Air Observations } & 76\end{array}$

AIR QUALITY BACKGROUND OBSERVATIONS 92

Hydrogen Sulfide $\quad 92$

Suspended Particulates $\quad 118$

HYDROGEN SULFIDE DISPERSION MODELING 121

Dispersion Model $\quad 121$

Preliminary Engineering Design Information $\quad 123$

Plume Rise Equation $\quad 123$

Meteorological Information $\quad 124$

Physical Input Information $\quad 125$

One-Hour $\mathrm{H}_{2} \mathrm{~S}$ Concentration Estimates $\quad 130$

Analysis of Results 139

References $\quad 140$

UPPER-AIR TEMPERATURES AND WINDS (16-24 AUGUST, 1975) 141 Upper-Air Temperature Profiles 142

$\begin{array}{lll}\text { Part II } & \text { Upper-Air Wind Tabulations } & 187\end{array}$ 
REPORT NO. 6

EXECUTIVE SUMMARY

BACA RANCH GEOTHERMAL SITE

GEOTHERMAL RADIOLOGICAL MONITORING PROGRAM

FROM A REPORT

Prepared For

UNION GEOTHERMAL DIVISION

UNION OIL COMPANY OF CALIFORNIA

LOS ANGELES, CALIFORNIA
Prepared By

CONTROLS FOR ENVIRONMENTAL

POLLUTION, INC.

SANTA FE, NEW MEXICO

NOVEMBER 1974

Summary Prepared By

WESTEC SERVICES, Inc.

ALBUQUERQUE, NEW MEXICO

MAY 1980 


\begin{abstract}
A radiological monitoring survey of the Baca Ranch which was conducted for the Union Oil Company of California by Controls for Environmental Polution, Inc. The survey was initiated in October of 1974 to perform air, terrestrial, and water monitoring in the areas surrounding the geothermal wells. The primary purpose of the surveillance was to provide information on the possible contamination of the environment from radiation being released from development of the geothermal resource.

Analytical results were presented and discussed along with other pertinent data. The study concluded that there is no hazard from radiation being introduced by the geothermal generations. The amounts of radiation detected were less than or equal to those taken as background levels from the literature and from sample analyses. The study recommended that periodic sampling be continued during development and use of the resource to further insure that no radiation is being introduced to the environment by the project.
\end{abstract}




\subsection{INTRODUCTION AND SCOPE}

The objective of the radiological survey was to provide information on the levels of radiation in the geothermal environs of the Baca Location No. 1 prior to geothermal operations. This information permits evaluation of corresponding concentrations and levels subsequent to operation, which may be attributable to the geothermal power plant.

Measurements were made for Gross Alpha, Gross Beta, and Gross Gamma activity as well as for radium -226 and lead -210 levels. Radon -222 content of the atmosphere was also surveyed. Analytical procedures varied depending on the medium being tested but were those routinely used by Controls of Environmental Pollution, Inc. in sample analyses.

High volume air particulate samples were taken from 24 sites including each of the Baca wells. Samples taken from Santa Fe and the Tsankivi Ruins were considered to represent background levels. Produced water was tested from the Baca No. 12 run-off pit and from two samples taken at Baca No. 11. Both the dissolved and suspended fraction were tested. Radiation levels in the vegetation of the area were assessed by analyzing oak leaves, conifers, and mixed grasses from three, six, and three sites, respectively. Soils were tested from twelve locations. Results were compared with levels reported in the literature for soils in the Los Alamos area. Sediment was collected from the Redondo and Sulphur Creeks and Jemez Springs for testing. Surface water was also analyzed and compared to domestic water. Three mice from two locations were analyzed to establish a data base for terrestrial animals and produced solids and drill cuttings were tested from Baca 11 and 13.

\subsection{SUMMARY AND CONCLUSIONS}

The report presented the interpretations and conclusions obtained for all media sampled during the Baca Ranch radiological survey. All samples were analyzed in duplicate. The results were within their respective statistical deviation. Therefore, the results presented in the report are of average values.

Numerical results of the analyses are too numerous for inclusion in this sum mary, however, their implications and resulting conclusions follow.

The study concluded that the radioactivity found in any of the samples was less than or equal to background levels reported in the literature or inferred from sample analyses and was predominately from major sources of radiological environmental pollution. Such sources of pollution are: (1) nuclear detonations, (2) nuclear fuel fabrications, (3) nuclear reactor operations, (4) nuclear fuel reprocessing, and (5) isotope production and use. The majority of such environmental pollution in the Baca Ranch region probably comes from nuclear detonations. Analysis of many samples also revealed that a portion of 
the radioactivity detected was due to natural sources such as radionuclides produced in the atmosphere or earth by bombardment from cosmic particles.

The study further stated that although some activity was detected in some sample media, the concentrations were of no significance insofar as health hazards are concerned. All existing levels of radioactivity were found to be well below the maximum permissable concentrations that have been determined to protect against health impacts.

The report concludes that no radioactive pollution is being introduced into the environment by geothermal wells of the area. Periodic sampling during drilling operations and full operation of the geothermal wells was recommended. 
TABLE OF CONTENTS FOR THE COMPLETE REPORT

\section{Section}

$\underline{\text { Title }}$

Page

1.0

1.1

1.2

1.3

1.4

INTRODUCTION

General Introduction

Abstract Summary

Description of the Baca Ranch Geothermal Sites

Description of the Monitoring Program

Union Oil Company of California Monitoring Program

ANALYTICAL PROCEDURES

High Volume Air Particulate Samples

Produced Water

Vegetation (Leaves, Conifers, and Grasses)

Soil and Creek Sediments

Creek and Domestic Water

Airborne Radon-222 by Filter Paper Method

Airborne Radon-222 by Absorption or Charcoal Method

Terrestrial Animals

6.0 ISOTOPIC DETECTION LIMITS AND ACTIVITY DETERMINATIONS 
TABLE OF CONTENTS FOR THE COMPLETE REPORT (Continued)

SCHEMATIC DRAWINGS OF SAMPLING LOCATIONS

Title

Page

Baca 1 and 3, Baca 7, and Seco Lake 87

Baca 2

88

Baca 4

Baca 5

Baca 6

Baca 7, Baca 1 and 3

Baca 8 and 2

Baca 8, and Westates Pet. Bond \#1

Baca 10

Baca 6 and 11

Baca 11

Baca 11 and 4

Baca 11

Baca 12

Baca 13

Redondo Creek, and Jemez Springs

Redondo Creek

89

90

91

92

93

94

95

96

97

98

99

100

101

102

103 


\author{
REPORT NO. 7 \\ EXECUTIVE SUMMARY \\ THE BIOTA OF REDONDO CREEK CANYON \\ SANDOVAL COUNTY, NEW MEXICO \\ WITH EMPHASIS ON BIG GAME SPECIES AND \\ RARE, ENDANGERED OR THREATENED SPECIES
}

FROM A REPORT

Prepared for

Prepared by

UNION GEOTHERMAL DIVISION

SOUTHWEST ENVIRONMENTAL RESEARCH

UNION OIL COMPANY OF CALIFORNIA

AND DEVELOPMENT CORPORATION

LOS ANGELES, CALIFORNIA

OCTOBER 1974

Summary Prepared by

WESTEC SERVICES, INC.

ALBUQUERQUE, NEW MEXICO

MAY 1980 


\section{ABSTRACT}

An initial inventory of the west slope of Redondo Peak and Redondo Creek Canyon (between 8000 and 9500 feet) was conducted during September and October, 1974. The objective of the study included limited field inventories of existing biological resources, analysis of current impact of human activities on the ecosystem of the area, and recommendations for future studies. Surveys were conducted in disturbed and undisturbed areas and included vegetation transects, avifauna surveys, small-mammal surveys, surveys for carnivores and ungulates, directed surveys for endangered species, and an organic-matter-outflow study of Redondo Creek.

Meadows and Ponderosa pine stands were found in the lower elevations of the study area. South-facing slopes at higher altitudes were predominately covered by Gambel (scrub) oak and/or Ponderosa pine, and north-facing slopes had a dense cover of fir, pine and aspen. Elevations above 9000 feet contained pine-fir or aspen communities with scattered small meadows and sedge marshes. Smallmammal diversity and density was lowest in Ponderosa parkland and was highest in pine-fir forests and pine and aspen communities. Tassel-eared squirrels, least chipmunks, red-backed voles, deer mice, and pocket gophers were common small mammals. Numerous bird species were recorded during the study, but the number decreased markedly above 9000 feet. The area also supported a variety of raptors. Black-tailed deer (mule deer) densities varied between three and eight per square mile. Pellet counts indicated that a herd of 200 to 500 elk may winter in the Redondo Creek Valley. The threatened Jemez Mountain salamander probably inhabits north- and northwest-facing slopes. In addition, prairie falcon (since delisted by the U.S. Fish and Wildlife Service) and American peregrine falcon occur in the region and may forage within the study area.

The system of pipelines and roadways present during the time of the survey presented only minor impact to biological resources. Future studies that are recommended to be conducted include vegetation mapping of the area, breeding bird census, surveys for the Jemez Mountain salamander, and deer and elk surveys. 
1.0 INTRODUCTION AND SCOPE

This report represents the first major study of the Redondo Creek Canyon study area. The scope of the study included (1) inventory of existing biological resources; (2) analysis of existing impact of human disturbance to the biological resources of the area; and (3) recommend future studies to be conducted in the study area. The study was conducted in September and October, 1974, and was limited in scope as well as duration.

The following surveys were conducted during the cource of the study:

1) Vegetation: A total of 14 sites were sampled through the use of the point-quarter method.

2) Small Mammals: Live-trapping grids of various sizes were used to determine small-mammal abundance. Squirrels were censused from roadside stops concurrent with avifaunal surveys. Gophers were estimated through burrow system analysis.

3) Large Mammals: Large-mammal activity was assessed through pellet counts and observation of tracks.

4) Avian Census: Roadside counts of all birds seen in ten minutes were spaced at 0.5 mile intervals from Baca gate to Baca $5 \mathrm{~A}$.

5) Rare and Endangered Species: Directed searches for Plethodon neomexicanus were conducted in likely habitat for the species.

6) Redondo Creek Organic Matter: One two-hour sample of organic matter transported down Redondo Creek was sampled.

Vegetation changes within the study area were due primarily to slope aspect and altitudinal gradients. The southwest-facing slopes are dry due to aspect. Scrub oak (Quercus gambelli) accounted for over 95 percent of the vegetative cover. Ponderosa pine occurred at greater frequency at higher altitudes. The northwest-facing slopes had lower tree-shrub density than the southeast-facing slopes; however the species diversity, size and canopy cover of dominant trees were greater on the northwest-facing slopes. Fir, pine and aspen were the dominant species on the northwest-facing slope. Meadows and Ponderosa pine meadows occurred in the more level area of the lower elevations of the study area. Alders and box elders were found in riparian areas and near the edge of meadows. Elevations above 9000 feet contained pine-fir or aspen communities with scattered meadows and sedge marshes. The investigators noted many plant species that were good forage materials for herbivorous large mammals. 
Leopard frogs (Rana pipiens) were found along Redondo Creek in freshwater seeps, and at high densities along the edges of beaver ponds. Cricket frogs (Pseudacris triseriata) were found within the meadows. The only reptile observed was a garter snake.

Dense cover on northwest-facing slopes supported high densities of redbacked voles, deer, mice and least chipmunks. Southeast-facing slopes supported lesser densities of the above species as well as ground squirrels and woodrats. The more open Ponderosa pine meadows supported only chipmunks and tassel-eared squirrels. The investigators found that open habitats supported lower densities of small mammals than habitats containing dense vegetation. Pocket gophers were found in moderate densities in the grassy meadows of the study area. Redsquirrel signs were noted within spruce-fir forested areas. Beaver were noted in a large pond on-site. The beaver pond served as a focal point for deer, cattle, and mammalian carnivores.

Activity and area usage by deer and elk in the study area was concentrated in certain plant communities and exhibited seasonal fluctuation. Elk densities in the study area were estimated between 200 and 500 head. Elk in the Redondo Creek Canyon are winter residents who move to high meadows in spring. Concentrations of elk are expected in the canyon from November to March. The upper slopes of Redondo and Redondo Border probably support the elk during fall and spring migrations. Areas at 9500 feet and higher may support some elk during summer months. Data on deer were less comprehensive than on elk. Deer densities appear low (approximately 3.2 deer per square mile). These animals exhibit some winter concentrations at low elevations, moving to higher elevations in spring.

The area supports a high diversity of mammalian carnivores. Coyote, bobcat, badger, raccoon, mountain lion, and bear are expected to occur in the study area.

Twenty-two avifauna species were noted during the survey. Bird densities were fairly evenly distributed throughout the study area in September, but there was a marked shift of populations to lower elevational habitats in October. Bird species including the grey-headed junco, black-capped chickadee, Wilson's warbler, flicker, mountain bluebird, western bluebird, Clark's nutcracker, white-throated swift, red-breasted nuthatch and pigmy nuthatch were found within the meadows in the lower elevations of the study area. Red-tailed hawks were noted throughout the study. Other raptors censused included the sharp-shinned hawk, Ferruginous hawk, kestrel and turkey vulture. The one Cooper's hawk and a peregrine falcon were noted during the study. The area supports a good diversity of raptors and is a potential breeding habitat for many of these species.

Three rare and/or endangered species may occur in the study area: 
1) Jemez Mountain Salamander: This species could occur on the northwest-facing slopes of the study area.

2) Prairie Falcon: This species probably uses the study area during migration. There is a low probability that the species nests in the study area. (This species has since been delisted by the U.S. Fish and Wildlife Service.)

3) American Peregrine Falcon: The individual noted during the study was probably a immigrant. There is a remote potential that peregrines nest in the study area.

A limited analysis of organic matter outflow of Redondo Creek was conducted. Organic export from Redondo Creek at the western edge of the study area was estimated at 1.7 grams dry weight/hour.

The report concluded that human activities at the study areas as of October 1974 have resulted in little adverse influence of biological resources. The report makes specific recommendations for future studies prior to development of geothermal fields:

1) Quantificaiton and mapping of plant communities within the study area.

2) Breeding-bird-population studies with emphasis on raptor species.

3) Suitable habitat for the Jemez Mountain salamander must be extensively surveyed.

4) Identification of prime habitat for deer and elk.

5) Small-mammal live trapping to determine food base for predators.

6) Documentation of vegetation changes around wells and pipeline corridors.

In addition, the report recommends that areas around wellheads be reseeded. Beaver ponds and sedge marshes should be avoided by construction activities. 
Summary, Conclusions and Recommendations 4

$\begin{array}{lr}\text { Introduction } & 8\end{array}$

Methods 12

$\begin{array}{ll}\text { Vegetation } & 16\end{array}$

Amphibians and Reptiles $\quad 23$

$\begin{array}{ll}\text { Small Mammals } & 24\end{array}$

$\begin{array}{ll}\text { Birds } & 39\end{array}$

Rare and Endangered Species $\quad 49$

General Behavior, Habits and Habitat Requirements of Elk 52

General Behavior, Habits and Habitat Requirements of Mule Deer 53

Big Game Animals $\quad 54$

Deer, Elk and Predator Numbers (State and Federal Data) 58

$\begin{array}{ll}\text { Predators } & 61\end{array}$

Redondo Creek Organic Matter Outflow

$\begin{array}{ll}\text { General Discussion } & 65\end{array}$

$\begin{array}{ll}\text { References } & 68\end{array}$ 
REPORT NO. 8

EXECUTIVE SUMMARY

REPORT ON RECONNAISSANCE OF

REDONDO CREEK, REDONDO BORDER, SULFUR CANYON, ALAMO CANYON

AND VALLE SECO AREAS WITH PROPOSAL AND BUDGET ESTIMATES

FOR BIOLOGICAL BASELINE STUDIES

FROM A REPORT

$\begin{array}{cc}\text { Prepared for } & \text { Prepared by } \\ \text { UNION GEOTHERMAL DIVISION } & \text { WHITFORD ECOLOGICAL CONSULTANTS } \\ \text { UNION OIL COMPANY OF CALIFORNIA } & \text { LAS CRUCES, NEW MEXICO } \\ \text { LOS ANGELES, CALIFORNIA } & \text { MAY 1975 }\end{array}$

Summary Prepared by

WESTEC SERVICES, INC.

ALBUQUERQUE, NEW MEXICO

MAY 1980 


\begin{abstract}
A brief reconnaissance of Redondo Creek, Redondo Border, Sulfur Canyon, Alamo Canyon and Valle Seco was conducted between March 23 and March 25, 1975. The purpose of the reconnaissance was to determine a preliminary habitat description of the area and define future studies in order to formulate a cost estimate for subsequent studies. Twelve habitat types and five special habitat sites were tentatively identified.
\end{abstract}




\section{$1.0 \quad$ INTRODUCTION AND SCOPE}

A brief reconnaissance of Redondo Creek, Redondo Border, Sulfur Canyon, Alamo Canyon and Valle Seco was conducted between March 23 and March 25, 1975. The purpose of the reconnaissance was to obtain preliminary data on habitat types, formulate scope and priorities for subsequent studies and formulate cost estimates for performance of subsequent studies. It should be noted that this report only contains preliminary data for use in preparing cost estimates.

\section{$2.0 \quad$ SUMMARY AND CONCLUSIONS}

Based on the field reconnaissance, habitat types and special habitat types for the Baca area were tentatively identified. Habitat types identified included spruce-fir forests (two subsets), white and Douglas fir forest, Douglas fir and blue spruce forest, Ponderosa pine forests (two subsets), Gambel oak woodland, dry meadow, wet meadow, and streamsides. Special habitat types included freshwater springs, seeps, ponds and pools, cliffs and Scree (talus slopes).

The report establishes priority for conducting future studies. These priorities are as follows.

1) Classification of vegetation types into standard habitats and mapping of vegetation.

2) Census of the entire area for rare or threatened species of animals.

3) Estimation of numbers of big game in the area during summer, and location of areas where elk or deer concentrate their activities, if such areas exist.

4) Census of breeding birds.

5) Sampling relative abundance of small mammals in the different habitats.

Cost estimates for each of these studies are included in the report. 


\section{TITLE}

Introduction

Methods

Expected Results

Budgets

Threatened and Rare Animal Species

Big Game Species

Avian Census

Mammal Census

Budgets

References Cited

Cirriculum Vitae: John L. Ludwig 
REPORT NO. 9

EXECUTIVE SUMMARY

WINTER ACTIVITY AND HABITAT USE BY ELK

IN THE REDONDO CREEK AREA

WITH COMMENTS ON ACTIVITIES AND

RELATIVE ABUNDANCE OF OTHER SPECIES

FROM A REPORT

Prepared for

UNION GEOTHERMAL DIVISION

UNION OIL COMPANY OF CALIFORNIA

LOS ANGELES, CALIFORNIA
Prepared by

WHITFORD ECOLOGICAL CONSULTANTS

LAS CRUCES, NEW MEXICO

AUGUST 1975

Summary Prepared by

WESTEC SERVICES, INC.

ALBUQUERQUE, NEW MEXICO

MAY 1980 


\section{ABSTRACT}

Winter habitat use and activity studies of elk were conducted from late January through late April, 1975. Winter elk herds occur in numbers of 30 to 50 animals as determined by visual counts. Pellet group counts gave estimates of a wintering herd size of nearly 200 animals in the Redondo Creek area and an additional herd of approximately 200 on the south side of Redondo Peak. Elk activity was generally at lower elevations (8200 to $9600 \mathrm{feet}$ ). Most activity was on relatively snow-free south-facing slopes of less than $45^{\circ}$ containing Gambel oak and scattered conifers.

Human activities within the study area did not appear to disturb the elk. Elk frequently moved along pipeline alignments and roadways. 
This study was conducted subsequent to initial field surveys in 1974 (Report No. 7). The initial survey indicated that 200 to 500 elk may use the valley floor as a winter habitat area. This study was initiated to provide quantitative and qualitative data on winter use of the study area by elk. The study was conducted between late January and late April, 1975.

Because overstory vegetation precluded accurate counts of elk by fixed-wing aircraft and helicopter, the study was limited to on-foot surveys with the aid of snowshoes. Methods employed included direct observation of herds, (using binoculars and indirect observations based on transects) for pellet distribution. Observations of browse patterns were also made.

\section{SUMMARY AND CONCLUSIONS}

Initial direct observation of elk indicated that two to three herds with 30 to 50 elk per herd occurred within the study. However, based on pellet group counts, the number of herds was revised to four herds in the Redondo Canyon area (up to 200 individuals) and an additional four herds (up to 200 individuals) on the south side of Redondo Peak. Elk activity was generally at lower elevations (8200 to 9600 feet). Most activity was on relatively snow-free south-facing slopes of less than $45^{\circ}$ containing Gambel oak and scattered conifers. Bedding areas were located in aspen groves. The report briefly lists other species encountered during the survey.

Human activity associated with geothermal operations in the winter of 1975 appeared to have no detrimental effect on wintering elk. Pipeline areas or other areas that were cleared as a result of geothermal operations may attract elk because of the ease of movement and availability of foraging materials. The report further recommends that areas of elk concentrations be avoided by future geothermal development activities. 
TITLE

$\underline{\text { PAGE }}$

Abstract

ii

Conclusions and Recommendations

iii

Introduction

1

Methods

1

Results

2

Discussion

24

Literature Cited 
REPORT NO. 10

EXECUTIVE SUMMARY

THE BIOTA OF THE BACA GEOTHERMAL SITE

FROM A REPORT

$\begin{array}{cc}\text { Prepared for } & \text { Prepared by } \\ \text { UNION GEOTHERMAL DIVISION } & \text { WHITFORD ECOLOGICAL CONSULTANTS } \\ \text { UNION OIL COMPANY OF CALIFORNIA } & \text { LAS CRUCES, NEW MEXICO } \\ \text { LOS ANGELES, CALIFORNIA } & \text { AUGUST 1975 }\end{array}$

Summary Prepared by

WESTEC SERVICES, INC.

ALBUQUERQUE, NEW MEXICO

MAY 1980 


\begin{abstract}
Vegetation was sampled at the Baca Geothermal area using a habitat type series scheme based on dominant overstory species. Eight habitat type series characterized the vegetation of the study area: spruce-fir forest, white fir and Douglas fir forest, blue spruce and alder habitat type, fir-pine-oak habitat type, oak-locust habitat site, fescue dry meadows and sedge wet meadows. A vegetation map was prepared delineating these habitat types. Studies were conducted during the summer of 1975 .

Forty-one bird species were noted during breeding. The highest density and diversity of breeding birds were found at meadow edges. Rodent densities were lower than recorded in the fall of 1974 apparently due to a heavy winter die-off. The greatest small-mammal densities recorded were on talus slopes. During summer, elks confined their activity to the higher elevations of Redondo Peak. Cows migrated to open forests below 9400 feet where their activity was concentrated along Redondo Border, Alamo Canyon and San Luis Creek Canyon.

Three currently listed threatened species were identified as occurring in the study area: American peregrine falcon, bald eagle and Jemez Mountain salamander. (The Mexican duck was also identified as threatened in the report, but has been subsequently delisted by the U.S. Fish and Wildlife Service). The peregrine falcon and bald eagle are apparently transient (not resident) to the area. The Jemez Mountain salamander occurred within the study area, and its habitat was mapped during the study.
\end{abstract}


This report summarizes major biological resources of the Baca Geothermal site and serves to augment an initial biological inventory and an inventory of the habitat of winter elk of the area in the fall of 1974 (Report No. 7). This study basically includes the scope of work outlined in a field reconnaissance conducted in March 1975 (Report No. 8). This report covers field analysis completed during the spring and summer of 1975. The report is divided into two major chapters: vegetative studies and faunal studes. In addition, a brief discussion of archaeological resources is included.

Vegetation was surveyed using standard plant ecology field methods. The series field data was tabulated, and these data were series grouped by cluster analysis. Habitat types were determined from this analysis. Estimates of elk and deer herd sizes were obtained on forty 0.1 -acre study plots by counting numbers of pellet groups present. Directed searches for the Jemez Mountain salamander were conducted in suitable habitats. In addition, a survey of suitable nesting habitat for peregrine falcons were checked. Breeding bird densities were estimated through the use of roadside censuses at 0.5 -mile intervals. Live trapping was conducted for small mammals in each major habitat type.

\subsection{SUMMARY AND CONCLUSIONS}

Eight habitat type series were identified and mapped during the study. These habitat type series were:

1) Spruce-fir Forest: This habitat type series occurred at higher altitudes in cool habitats with well-drained soils.

2) White fir and Douglas Fir Forest: This habitat type occurred between 8500 and 10,500 feet on shallow and rocky soils.

3) Blue Spruce and Alder: This habitat type series occurred along the slopes or bends of ereeks on the study area.

4) Fir-pine/Gambel Oak/Grass Woodland: The habitat type series was characterized by grassland areas having an overstory of large, low-density Ponderosa pine.

5) Oak and Locust Scrub: This habitat type series was found on very steep and rocky south- and west-facing slopes.

6) Fescue Dry Meadow: These grasslands were found on gently sloping valleys, canyons and mountain sides where deep, welldrained soils have developed.

7) Sedge Wet Meadow: This habitat type series was found along semipermanent running, meandering, slow creeks. 
8) Open Shrub Talus: This habitat type series was found on steep rock slide areas of Redondo Peak.

The white fir and Douglas fir habitat type series was most extant on the study area. Spruce-fir forests covered a relatively large area near Redondo Peak. Oak and locust scrub, fir-pine/oak/grass woodlands and fescue dry meadows covered relatively large areas, but were diffuse in their distribution in the study area.

During the summer, elk bulls confined their activity to higher elevations of Redondo Peak. Cows migrated to the open forests near meadows below 9400 feet along Redondo Border, Alamo Canyon and San Luis Creek Canyon. Summer elks were estimated at 336 animals.

Small-mammal-species composition was similar to previous findings (Report No. 7). Populations declined over 80 percent from the previous studies. This decrease is probably due to the extended and unusual period of snow cover during the winter of 1974-1975.

Forty-one species of breeding birds were recorded. These included several raptor species. Peregrine falcons were observed in the Valle Seco and San Luis Creek area. This area is used as a foraging habitat. No nesting sites were observed during the study. (The report also identified this area as a potential habitat for the Mexican duck. The U.S. Fish and Wildlife Service has since delisted this species.)

The threatened Jemez Mountain salamander was found within the study areas. Concentrations of this species were found in large areas on the Redondo Border, Redondo Peak, and an isolated area on San Antonio Mountain.

Several extensive archaeological sites were also found during the survey. Materials collected were sent to qualified archaeologists for evaluation.

Several recommendations and conclusions were made in the report as follows:

1) Additional small-mammal surveys should be conducted to document the cause and extent of population fluctuations.

2) Studies should be conducted to evaluate the compatability of breeding birds with geothermal operations.

3) Further studies should be conducted to evaluate the importance of the study area to the peregrine falcon.

4) Elk appear to be little affected by geothermal operations on the study site.

5) Archaeological surveys should be conducted before further exploratory work or development occurs. 
$\begin{array}{ll}\text { Summary, Conclusions and Recommendations } & 1\end{array}$

$\begin{array}{ll}\text { General Introduction } & 6\end{array}$

$\begin{array}{lr}\text { Chapter One - Vegetative Studies } & 8\end{array}$

Introduction $\quad 8$

$\begin{array}{ll}\text { Study Area } & 11\end{array}$

$\begin{array}{ll}\text { Methods } & 11\end{array}$

Field Sampling of Stands 11

Data Tabulation 13

Community Analysis 17

Association Analysis 18

$\begin{array}{ll}\text { Mapping } & 18\end{array}$

Results and Discussion

Hierarchial Classification of Stands $\quad 22$

Delimitation of Habitat Type Series $\quad 24$

Description of the Habitat Type Series 28

Spruce-Fir Forest HTS 28

White Fir and Douglas Fir Forest HTS 32

Blue Spruce and Alder Streamside HTS 40

Fir-Pine/Oak/Grass Woodland HTS 45

Oak-Locust Scrub HTS 48

Fescue Dry Meadow HTS

Sedge Wet Meadow HTS $\quad 59$ 
TABLE OF CONTENTS FOR THE COMPLETE REPORT (Continued)

$\underline{\text { TITLE }}$

$\underline{\text { PAGE }}$

Open Shrub Talus HTS

Mapping of Habitat Type Series

Mapping of Present Plant Communities

Chapter Two - Faunal Studies

Introduction

Methods

Big Game (Elk and Deer)

Rare and Endangered Species

Breeding Birds

Small Mammals

Observational Notes

Results and Discussion

Small Mammals

Mammals (Other than Big Game)

Breeding Birds

Reptiles and Amphibians

Rare and Endangered or Threatened Species

Big Game (Elk and Deer)

Archaeological Sites 
REPORT NO. 11

EXECUTIVE SUMMARY

STUDIES OF RARE AND/OR ENDANGERED SPECIES

ON THE UNION-BACA GEOTHERMAL LEASE AND SURROUNDING AREA

WITH DISCUSSION OF OTHER SPECIES

FROM A REPORT

Prepared for

UNION GEOTHERMAL DIVISION

UNION OIL COMPANY OF CALIFORNIA

LOS ANGELES, CALIFORNIA
Prepared by

WHITFORD ECOLOGICAL CONSULTANTS

LAS CRUCES, NEW MEXICO

AUGUST 1975

Summary Prepared by

WESTEC SERVICES, INC.

ALBUQUERQUE, NEW MEXICO

MAY 1980 


\begin{abstract}
Surveys were conducted in the spring and summer of 1977 to provide additional data on the status of the peregrine falcon, Mexican duck and Jemez Mountain salamanders within the Baca Geothermal Development area. (The Mexican duck has since been delisted by the U.S. Fish and Wildlife Service). One peregrine falcon sighting was made during 173.5 man hours of observation indicating a pair of falcons may nest some distance from the study site and made occasional hunting forays into the study area. No Mexican ducks were found during the survey. Large numbers of suitable habitat patches for the Jemez Mountain salamander containing dense populations of the species were found in the study area.
\end{abstract}


Surveys to supplement previous inventories of the Baca Geothermal area (Reports No. 7 and No. 10) were conducted during the spring and summer of 1977 to provide additional data on the status of three threatened/endandered wildlife species that may occur within the area. The species of interest were: the peregrine falcon, Mexican Duck and Jemez Mountain salamander. (The Mexican duck has since been delisted by the U.S. Fish and Wildlife Service).

Surveys were conducted during spring and early summer for the peregrine falcon. This survey included searches of potential nesting sites on rocky cliffs in areas away from human disturbance. Observations were conducted at the onsite beaver pond in order to attempt to identify Mexican ducks. Surveys were conducted along potential roadway alignments and at potential well sites for the Jemez Mountain salamander.

\section{$2.0 \quad$ SUMMARY AND CONCLUSIONS}

A total of 173.5 man hours of observation during 1977 resulted in only one confirmed sighting of a peregrine falcon and used the site as an occassional foraging area. Searches of potential nesting sites within the study area failed to identify any active nests. These data suggest that one or possibly a pair of falcons nested some distance from the Baca Geothermal site. The report concluded that no peregrine falcons nested within the study area during the spring and summer of 1977.

No Mexican ducks were observed during 1977. New Mexico Fish and Game observed Mexican ducks during earlier years (the Mexican duck has since been delisted by the U.S. Fish and Wildlife Service).

Extensive surveys of the Jemez Mountain salamander within the Baca Geothermal area resulted in the discovery of a large number of suitable habitat patches containing dense populations. These areas of high species densities were mapped. Populations were predominately found on dense north-facing slopes, although populations were also found on south-facing slopes. The report concluded that construction of roadways and wells would unavoidably affect some populations of the species. Efforts should be made to avoid large population concentrations.

Ancillary to the scope of the study, observations on elk were also made. The report noted that elk herds appeared to be healthy and to have grown in number from the time of previous surveys (Report No. 9). 


\section{TITLE}

\section{INTRODUCTION}

\section{METHODS}

\section{RESULTS AND DISCUSSION}

Assessment of the Status of Peregrine Falcons on and Around the Union Baca Geothermal Lease, Summer 1977.

Assessment of the Status of Mexican Duck on and Around the Union Baca Geothermal Lease, Summer 1977.

Assessment of the Status of Jemez Mountain Salamander on and Around the Union Baca Geothermal Lease, Summer 1977.

Assessment of the Status of Other Species on and Around the Union Baca Geothermal Lease, Summer 1977.

\section{REFERENCES}

Report on Biological Reconnaissance of the Southeast Slope and Valley of the Redondo Border, Baca Geothermal Location

Plethodon neomexicanus - Jemez Mountain Salamanders

Elk and Other Species

Interim Report on the Biological Surveys of the Baca Geothermal Project Area 
REPORT NOS. $12,13,14$

EXECUTIVE SUMMARY

\author{
HYDROLOGY \\ JEMEZ MOUNTAINS, NEW MEXICO \\ and Addendum: \\ MODEL OF STREAMFLOW DEPLETION \\ OF THE
}

JEMEZ RIVER BY GEOTHERMAL DEVELOPMENT

IN THE VALLES CALDERA, NEW MEXICO

FROM REPORTS

Prepared For

UNION GEOTHERMAL DIVISION

UNION OIL COMPANY OF CALIFORNIA

LOS ANGELES, CALIFORNIA
Prepared By

WATER RESOURCES ASSOCIATES, INC

SCOTTSDALE, ARIZONA

MARCH 1977

Summary Prepared By

WESTEC SERVICES, Inc.

ALBUQUERQUE, NEW MEXICO

MAY 1980 


\begin{abstract}
Hydrologic data collected on the Baca Geothermal Lease between October 1975 and March 1977 were compiled and analyzed by Water Resources Associates. Preliminary interference and re-injection tests were performed on eleven geothermal test wells in the Redondo Canyon area by Union Oil, Geothermal Division. Data was supplied by Union Oil concerning geology and fluid levels in the Caldera, quality of the geothermal waters and other data pertinent to the hydrology and geohydrology of the area. A monitoring program was initiated as part of the research leading to this report. The purpose of this report is to present the results of the monitoring program and to evaluate regional and local groundwater conditions and water quality in their relation to hydrologic problems. A preliminary evaluation of the effects of steam production in the Valles Caldera on the hydrology of the Rio Grande Basin is presented. Recommendations as to the monitoring and evaluation programs are also included.

An addendum to the original report involved two phases of modeling. First, a simplified model was found to be too inflexible to simulate conditions from the reservoir. A refined model was then developed which better simulated conditions and the predicted impact of development in the area. Both models employed Darcy's Law.

Examination of hydrologic and water quality data indicates that groundwater discharge from the Valles Caldera occurs as leakage from a deep caldera reservoir as hot springs and seeps along the Jemez River in the vicinity of San Diego Canyon. Digital modeling of the hydrologic system of the caldera indicates that development and operation of a $55 \mathrm{MWe}$ geothermal power plant will deplete streamflow in the Jemez River by about $7 \mathrm{gpm}(0.02 \mathrm{cfs})$ after 25 years of operation.
\end{abstract}


This report on the Baca geothermal area (Hydrology:Jemez Mountains, New Mexico) is a synthesis and interpretation of the hydrology of the region surrounding the Valles Caldera. This report was prepared by Water Resources Associates (WRA), and utilized existing literature previously presented as U.S. Geological Survey Professional Papers and Water Supply Papers, field conference guidebooks of the New Mexico Geological Society, Los Alamos Scientific Laboratory Informal Reports, and several other sources. In addition, previously unpublished data from four new surface water monitoring stations established in the area of 1975, and groundwater observations in 15 non-flowing (static water level) wells, seven flowing wells and four thermal springs were used as the bases for this report.

\subsection{MONITORING PROGRAM}

The thermal springs monitored were San Antonio Hot Springs, Spence Springs, McCauley Springs, and Soda Springs (discharge, temperature, and quality). The new surface water monitoring stations were in Redondo Creek, Sulphur Creek, San Antonio Creek, and the East Fork of the Jemez River (interrupted flow and quality). These stations were to complement the established long-term station on the Jemez River below the confluence with the East Fork, but were found to be noninformative and abandonment was suggested.

Flowing (discharge, temperature, and quality) and non-flowing (water level and quality) wells which were examined were too numerous to give locations in this summary, but included scattered water-supply wells and geothermal wells in the Valles Caldera area. The data from the monitoring program are contained in the report as Appendices I and $\Pi$.

\section{$1.2 \quad$ HYDROGEOLOGIC SETTING}

The landform, surface water drainage features, and water bearing characteristics of the geologic formations in the vicinity of the Baca demonstration project are controlled by the geology of the Valles Caldera. The WRA report refers the reader to a report by Union Geothermal Division for a discussion of the geology of the Caldera. Landform and surface drainage features are described from topographic maps with some of the geographic names in the region anglicized by the writers. The major drainage divides in the area are along the rim of the Caldera depression formed by the collapse of the roof and sides of a volcanic magma chamber. The lithologies involved and the age of this event are not given.

The uppermost layers of the caldera filling are essentially impermeable, whereas the remainder of the caldera filling and the rocks which compose the caldera walls are of moderate to low permeability. The shallow covering of caldera fill is of fairly high permeability. Away 
from the caldera, the region is underlain by Paleozoic and Mesozoic sedimentary rocks, Tertiary valley-fill deposits, lavas and tuffs (volcanic ash deposits).

1.3 GROUNDWATER MOVEMENT IN THE JEMEZ MOUNTAINS REGION

Groundwater observations in the shallow aquifer system and from the deeper geothermal system are provided in the WRA report as Appendix II. The data indicate an 800 to 1200 foot vertical separation between the two aquifers. Groundwater data are presented in the WRA report by an illustration (Plate I) showing groundwater contours and water level profiles. Groundwater elevations are highest near the rim of the caldera except where the rim breached by the Jemez River and the East Fork of the Jemez River. Groundwater contours indicate flow paths generally into the central portion of the caldera depression or away from the caldera on all sides except in the aforementioned river canyons, where groundwater flow is indicated to be down-canyon.

The WRA report indicates that water from the deep caldera reservoir does not discharge at Sulphur Springs or San Antonio Hot Springs. The water discharging at those springs is reportedly heated in the upper aquifer. Discharge from Spence Springs and McCauley Springs is composed of a very small quantity of deep caldera reservoir water, whereas Soda Springs is composed of a larger percentage of deep circulating water. Temperature of hot springs decrease downstream from Spence and McCauley Springs to Jemez Hot Springs.

The probable eastern limit of the deep reservoir is reported to be approximately six miles east of Redondo Canyon, from which the report concludes that the deep caldera reservoir water is not moving eastward toward the Los Alamos area or the Rio Grande. The possibility of water moving from the deep caldera reservoir to the north is precluded by a groundwater divide. Westward movement of groundwater from the Valles Caldera is similarly precluded by a groundwater ridge, although very deep circulation to the thermal springs in the Rio Salado drainage is possible according to the WRA report. Groundwater discharge from the deep caldera reservoir is near the thermal springs in San Diego Canyon.

\section{HY HROCHEMISTRY}

Stiff diagrams (which express water chemistry data in a format that facilitates rapid qualitative comparison of several analyses) of the chemical composition of waters from the springs, wells, and surface flows in the Baca area are presented in Appendix III of the WRA report. The cations included on these diagrams are $\mathrm{Na}+, \mathrm{K}+, \mathrm{Ca}^{++}$, and $\mathrm{Mg}^{++}$, and the anions are $\mathrm{Cl}^{-}, \mathrm{HCO}_{3}^{-}, \mathrm{CO}_{3}=$, and $\mathrm{SO}_{4}=$. The deep, slowly circulating waters are those with high sodium and chloride and/or sulfur (sulfate) ions predominating. The shallow circulating waters are predominately bicarbonate waters with high calcium and/or sodium 
concentrations. The intermediate zone contains water of mixed composition. Chemical data support the conclusion that thermal springs near Rio Salado may be associated with the deep caldera reservoir.

Electric conductivity of water in the area is illustrated as Plate II of the WRA report. Conductivity data support the interpretations of the groundwater level contours in that they show that waters of higher concentration of dissolved solids do not move out of the caldera except along the Jemez River Valley; that is, the high concentration waters are found in the deep wells in Redondo Canyon and Sulphur Creek as well as in other thermal springs and deep wells in the area. These data are also shown in the WRA report on Plate III - Sodium Concentrations.

The WRA report suggests that the caldera has been gradually sealing, (loosing permeability) as evidenced by reports that mineral springs in the area have been gradually drying up in recent years. It is considered possible that this sealing process may be well advanced.

Uranium concentration was found to be highest in Sulphur Creek $(0.7$ parts per billion, ppb), lowest in Redondo Creek (0.1 ppb) and intermediate in San Antonio Creek above Sulphur Creek $(0.4 \mathrm{ppb})$. These data could not be used as a tracer of groundwater movement or as a source indicator. Silica concentrations were presented in the WRA report; but were not interpreted as an indicator of deep circulation.

Data on the occurrence of arsenic are presented in the WRA report as Plate IV. Arsenic concentrations are relatively low in the area except in the Jemez River Canyon, the San Ysidro Spring area, and portions of the Rio Salado and Rio Puerco drainages where the concentrations are relatively high. Low concentrations range from 10 to $40 \mathrm{ppb}$ as compared to 4000 to $4500 \mathrm{ppb}$ in the Baca wells. Arsenic concentrations were used to compute mixing ratios. These ratios varied from 0.00425 and $\mathbf{0 . 0 1 7 5}$ at McCauley Springs and Spence Springs, respectively, to 0.195 and 0.275 at Jemez Springs and Soda Springs, respectively.

1.5 GROUNDWATER HYDRAULICS

Consumptive use of groundwater resulting in streamflow depletion was calculated in the WRA report for operation of a 55 megawatt power plant. It was shown that the streamflow would diminish by about 15 gallons per minute (gpm) (24 acre-free per year) after 25 years of power plant operation. Following $\mathbf{5 0}$ years of operation, the depletion would be about $26 \mathrm{gpm}$ (42 acre-free per year). The WRA report suggests that this streamflow depletion could be mitigated by acquiring and retiring water rights from approximately 19 acres of irrigated land in 25 years and 38 acres in $\mathbf{5 0}$ years. 
The Addendum to the WRA report on the hydrology of the region surrounding the Valles Caldera is a description of a refined model developed to estimate steamflow depletion resulting from geothermal development. Derivation of this model is presented as Appendix I, and the computational results are presented as Appendix II to the Addendum.

The original model assumed that the caldera was larger than was later determined from more detailed geologic maps, and the hydrostatic head inside the caldera was approximately that of the Jemez River where it crossed the caldera rim. In addition, possible recharge from the Jemez River was ignored. The values of the various parameters used in the original model are not given, though some become apparent from the refined model.

The refined model assumed a more realistic size for the caldera (radius of an equivalent circular caldera equal to 4.58 miles), an initial hydrostatic head at an elevation of 8281 feet (averaged from the free water surface in the Baca wells), and at an elevation of 7600 feet, elevation of the Jemez River at the caldera rim, for a later calculation run. The refined model also considered the elevation of the base of the caprock within the caldera (6435 feet), porosity (calculated at 10 percent and 1 percent), recharge to the caldera (266 ac-ft/yr), and power plant consumption ( 1150 gallons per minute). Initial leakage from the caldera was assumed to be $165 \mathrm{gpm}$, and boundary conditions over an arc of $\mathbf{7 0}$ degrees near the Jemez River were based on groundwater contours.

The refined model, using an initial head of 8281 feet elevation, a transmissivity of $7.94 \mathrm{ft}^{2} /$ day, and one percent porosity, yielded a streamflow depletion of about $17 \mathrm{gpm}$ after 25 years, assuming ten percent porosity yielded a depletion of about $4 \mathrm{gpm}$ over the same time period. Using an initial head at 7600 feet elevation, a transmissivity of $26.1 \mathrm{ft}^{2} /$ day and ten percent porosity resulted in a streamflow depletion of $7 \mathrm{gpm}$ after 25 years. The author of the Addendum favors the latter depletion calculation as most nearly representing the actual case. 
INTRODUCTION 1

MONITORING PROGRAM 3

Surface Water Measurements 3

New Gaging Stations 3

Conclusion Regarding the Stream Gaging Stations 4

Monitoring of Thermal Springs and Wells 5

HYDROLOGIC SETTING

$\begin{array}{ll}\text { GEOLOGY } & 7\end{array}$

WATER BEARING CHARACTERISTICS OF GEOLOGIC FORMATION 9

GROUNDWATER MOVEMENT, JEMEZ MOUNTAINS REGION 9

HYDROCHEMISTRY

Evaluation of Water Guality 16

Dissolved Solids Measured by Conductivty 17

Waters of Shallow and Deep Circulation 18

Mixed Waters 19

Trace Elements and Determination of Water Sources 19

Dissolved Silica 20

$\begin{array}{ll}\text { Arsenic } & 20\end{array}$

GROUNDWATER HYDRAULICS

\section{LIST OF TABLES}

TABLE

TITLE

PAGE

1 Elevation of Top of Water 


\section{LIST OF FIGURES}

FIGURES

TITLE

PAGE

1

Hydrographs

2 Profile of Spring Outlets and Water Levels From The Caldera to San Ysidro

Profile of Spring Outlets and Water Levels From The Caldera to Los Alamos Vicinity

Profile of Spring Outlets and Water Levels From The Caldera to Canones Vicinity

\section{APPENDICES}

APPENDIX

TITLE

I

STREAMFLOW DATA

II

BASIC DATA

Part 1 Pressure Survey Data, Union Geothermal Division

Part 2 Selected Wells, Springs and Surface Water Gaging Stations

Data Sources

Part 3 Water Quality Data

Part 4 Trace Elements

, Geothermal Source Analyses

III

CHEMICAL DIAGRAMS 
TABLE OF CONTENTS FOR THE ADDENDUM

TITLE

INTRODUCTION

ORIGINAL MODEL

REFINED MODEL OF THE VALLES CALDERA

General Equations

Boundary Conditions

Initial Conditions

Additional Considerations

RESULTS

APPENDIX I - Derivation of Model

APPENDIX II - Initial Input into the Model 
SAMPLE DATA SHEETS 


\begin{tabular}{|c|c|c|c|c|c|c|}
\hline No. & Date & Arsenic & Boron & Iron & Lithium & Mangane \\
\hline 2 & $12 / 12 / 74$ & 20 & 150 & 110 & 100 & 0 \\
\hline 3 & $12 / 12 / 74$ & 7 & 80 & 80 & 100 & 0 \\
\hline 9 & $8 / 26 / 72$ & 110 & 2,200 & 800 & --- & -- \\
\hline 13 & $9 / 25 / 74$ & 4. & 210 & 3,000 & 200 & 70 \\
\hline 17 & $10 / 18 / 74$ & $190^{\circ}$ & 8,200 & $\ldots$ & 7,100 & -- \\
\hline 18 & $5 / 2 / 73$ & 210 & 20 & 800 & --- & 740 \\
\hline 20 & $4 / 4 / 74$ & 4. & 110 & 1,700 & 60 & 0 \\
\hline 22 & $6 / 5 / 73$ & $0^{\circ}$ & 1,800 & 30 & 1,200 & 20 \\
\hline 23 & $6 / 5 / 73$ & 360 & 7,500 & 1,400 & $\ldots$ & 90 \\
\hline 24 & $10 / 2 / 73$ & 2 & 290 & 0 & 210 & 13 \\
\hline 28 & $5 / 23 / 73$ & 3 & 50 & 60 & --- & 20 \\
\hline 29 & $5 / 23 / 73$ & 0 & 20 & 30 & --- & 0 \\
\hline 30 & $9 / 5 / 73$ & 2 & -- & 15,000 & 640 & 260 \\
\hline 31 & $9 / 5 / 73$ & $5^{\circ}$ & 1,200 & 80 & 1,100 & 630 \\
\hline 32 & $5 / 24 / 73$ & 86 & 5,800 & 1,500 & $>2,800$ & 340 \\
\hline 33 & $5 / 24 / 73$ & 8 & 320 & 400 & -- & 210 \\
\hline 34 & $5 / 24 / 73$ & 0 & 170 & 40 & -- & 0 \\
\hline 35 & $8 / 30 / 73$ & 17 & 990 & 540 & 890 & 750 \\
\hline 36 & $8 / 30 / 73$ & 69 & 8,200 & 50 & 6,700 & 1,300 \\
\hline 40 & $5 / 24 / 73$ & 20 & 3,300 。 & 30 & -- & 70 \\
\hline 41 & $5 / 25 / 73$ & 43 & 670 & 90 & -- & 80 \\
\hline 42 & $6 / 8 / 73$ & 15 & 50 & 20 & -- & 0 \\
\hline 46 & $8 / 31 / 73$ & 0 & 840 & -- & 50 & - \\
\hline 49 & $8 / 21 / 73$ & 67 & F 380 & 140 & --- & 80 \\
\hline 51 & $11 / 2 / 73$ & 0 & 210 & 60 & 140 & 250 \\
\hline 52 & $1 / 29 / 74$ & 50 & 1,000 & 30 & 960 & 120 \\
\hline 54 & $10 / 5 / 73$ & 68 & 1,300 & 90 & 1,500 & 80 \\
\hline 56 & $6 / 6 / 73$ & 1 & 60 & 450 & -- & 380 \\
\hline 57 & $10 / 2 / 73$ & 5 & 20 & 20 & 10 & 8 \\
\hline 61 & $8 / 28 / 73$ & 1 & 10 & 10 & 10 & 0 \\
\hline 64 & $10 / 30 / 73$ & 0 & 60 & 10 & 60 & 10 \\
\hline 66 & $10 / 30 / 73$ & 2 & 10 & 20 & 20 & 0 \\
\hline 67 & $10 / 30 / 73$ & 0 & 10 & 80 & 30 & 0 \\
\hline 69 & $6 / 7 / 73$ & 6 & 2,200 & -- & -- & -- \\
\hline 72 & $7 / 18 / 74$ & 26 & 370 & 10 & 560 & 0 \\
\hline 75 & $3 / 8 / 73$ & 1,100 & 14,000 & -- & -- & -- \\
\hline 77 & $5 / 30 / 74$ & 780 & 7,400 & 450 & 7,800 & 300 \\
\hline 78 & $1 / 29 / 74$ & 120 & 85 & 50 & 1,300 & 30 \\
\hline 79 & $9 / 27 / 73$ & 150 & 1,200 & 30 & 1,400 & 0 \\
\hline 82 & $7 / 3 / 74$ & 5 & 2,100 & -- & 370 & -- \\
\hline 85 & $5 / 28 / 74$ & 230 & 1,900 & 750 & 2,300 & 820 \\
\hline 88 & $6 / 21 / 73$ & 5 & 180 & 9 & - & 20 \\
\hline 91 & $7 / 13 / 73$ & 4 & 140 & 30 & -- & 0 \\
\hline 96 & $9 / 18 / 73$ & 1 & 20 & 110 & 0 & 0 \\
\hline 114 & $3 / 8 / 73$ & 3 & 3,300 & -- & -- & -- \\
\hline
\end{tabular}


WATER QUALITY DATA

Jeme $z$ Basin and Vicinity

\begin{tabular}{|c|c|c|c|c|c|c|c|c|c|c|c|c|}
\hline $\begin{array}{l}\text { Data } \\
\text { No. }\end{array}$ & Date & $\mathrm{Ca}^{++}$ & $\mathrm{Mg}^{++}$ & $\mathrm{Na}^{+}$ & $\mathrm{k}^{+}$ & $\mathrm{HCO}_{3}^{-}$ & $\mathrm{SO}_{4}^{--}$ & $\mathrm{Cl}^{-}$ & TDS & Ec & $\mathrm{pH}$ & $\begin{array}{l}\text { Temp } \\
{ }^{\circ} \mathrm{F}\end{array}$ \\
\hline & & & & & & . & & & & & & \\
\hline \multicolumn{13}{|l|}{1} \\
\hline 2 & & 18.0 & 3.5 & 53.0 & 5.0 & 127.0 & 43.0 & 6.8 & 265.0 & 367 & -- & 67 \\
\hline 3 & & 28.0 & 5.0 & 36.0 & 7.6 & 156.0 & 35.0 & 7.3 & 264.0 & 352.0 & 7.4 & 55 \\
\hline 4 & $4 / 27 / 65$ & 57.0 & 10.0 & 29.0 & - & 134.0 & 58.0 & 51.0 & 343.0 & 501.0 & 7.8 & - \\
\hline 5 & & 31.0 & 5.9. & 30.0 & 6.4 & 142.0 & 37.0 & 7.4 & 255.0 & 348.0 & 7.5 & 61 \\
\hline 6 & $2 / 26 / 65$ & 112.0 & 17.0 & 60.0 & -- & 357.0 & 143.0 & 22.0 & 598.0 & 878.0 & 7.5 & $-\dot{-}$ \\
\hline 7 & $1 / 21 / 65$ & 60.0 & 11.0 & 69.0 & -- & 248.0 & 85.0 & 37.0 & 457.0 & $666: 0$ & 7.5 & - \\
\hline 8 & & 41.0 & 6.8 & 79.0 & 7.9 & 200.0 & $\because \quad 40.0$ & 72.0 & 421.0 & 642.0 & -- & 81 \\
\hline 9 & $8 / 26 / 72$ & 1.2 & 0.3 & 740.0 & 22.0 & $334 / 226$ & 49.0 & $9 \% .0$. & $2,460.0$ & $3,140.0^{\circ}$ & 9.5 & 90 \\
\hline 10 & $10 / 9 / 73$ & 80.0 & 14.0 & 330.0 & 16.0 & $348.0^{\circ}$ & 290.0 & 280.0 & $1,220.0$ & $1,950.0$ & 8.1 & 54 \\
\hline 11 & $3 / 10 / 66$ & 54.0 & 7.4 & 175.0 & - & 274.0 & 90.0 & 161.0 & 662.0 & $1,110.0$ & 7.6 & - \\
\hline 11 & $6 / 22 / 66$ & 79.0 & 9.5 & 278.0 & 15.0 & 330.0 & 266.0 & 228.0 & $1,070.0$ & $1,720.0$ & 7.5 & -- \\
\hline 12 & & 65.0 & 15.0 & 77.0 & 11.0 & 294.0 & 29.0 & 35.0 & 548.0 & 749.0 & 6.6 & 78 \\
\hline 13 & & 150.0 & 22.0 & 50.0 & 3.0 & 1930 & 350.0 & 24.0 & 780.0 & $1,050.0$ & - & 67 \\
\hline $13 \mathrm{~A}$ & & 210.0 & 51.0 & 180.0 & 11.0 & 514.80 & 580.0 & 53.0 & $1,420.0$ & $1,880.0$ & 6.4 & 71 \\
\hline 14 & $2 / \cdot 4 / 65$ & 117.0 & 22.0 & 88.0 & -- & 388.0 & న 218.0 & 19.0 & 691.0 & $1,020.0$ & 7.5 & -- \\
\hline 15 & $9 / 15 / 24$ & 494.0 & 91.0 & $3,310.0$ & -- & $1,969.0$ & $3,401.0$ & $2,500.0$ & 10,960 & -- & - & 86 \\
\hline 16 & & 100.0 & 9.0 & -- & -- & $1,280.0$ & 286.0 & $1,140.0$ & $3,470.0$ & $5,680.0$ & 8.0 & 95 \\
\hline 17 & & -- & -- & $3,900.0$ & 140.0 & - & -- & $2,800.0$ & - & $20,000.0$ & -- & 64 \\
\hline 18 & $9 / 15 / 24$ & 368.0 & .85 .0 & $2,219.0$ & -- & $1,757.0$ & $1,712.0$ & $1,940.0$ & $7,320.0$ & -- & - & 68 \\
\hline $18 \mathrm{~A}$ & $5 / 2 / 73$ & 300.0 & 68.0 & $2,000.0$ & 81.0 & $1,970.0$ & $1,300.0$ & $1,900.0$ & $6,650.0$ & $9,930.0$ & 6.5 & 63 \\
\hline 19 & $2 / 27 / 65$ & 48.0 & 9.0 & 46.0 & -- & 158.0 & 66.0 & 36.0 & 330.0 & 519.0 & 7.6 & -- \\
\hline 20 & & 49.0 & 1.5 & 56.0 & 5.5 & 228.0 & 57.0 & 4.2 & 332.0 & 490.0 & 7.9 & 63 \\
\hline 21 & $1 / 21 / 65$ & 147.0 & 25.0 & 92.0 & -- & 205.0 & 450.0 & 22.0 & 872.0 & $1,190.0$ & 7.3 & -- \\
\hline 22 & $6 / 5 / 73$ & 120.0 & 9.0 & $2,400.0$ & 6.6 & 241.0 & $4,500.0$ & 580.0 & $7,760.0$ & $10,100.0$ & 8.5 & 70 \\
\hline 23 & $6 / 5 / 73$ & 380.0 & 61.0 & $3,500.0$ & 88.0 & $1,410.0$ & $3,300.0$ & $3,100.0$ & $11,100.0$ & $15,700.0$ & 6.8 & 126 \\
\hline 24 & $10 / 2 / 73$ & 77.0 & 26.0 & 100.0 & 5.5 & 335.0 & 120.0 & 82.0 & 599.0 & 960.0 & 7.9 & 79 \\
\hline \multicolumn{13}{|l|}{25} \\
\hline 26 & $9 / 29 / 74$ & 400.0 & 73.0 & $3,450.0$ & -- & $1,498.0$ & $3,645.0$ & $2,660.0$ & $11,120.0$ & - & - & 115 \\
\hline 27 & $9 / 14 / 74$ & 260.0 & 70.0 & $2,400.0$ & -- & $1,301.0$ & $1,728.0$ & $2,370.0$ & $7,510.0$ & -- & - & 70 \\
\hline 28 & $5 / 23 / 73$ & 57.0 & 13.0 & 28.0 & 2.6 & 217.0 & 63.0 & 9.3 & 310.0 & 487.0 & 7.6 & 60 \\
\hline 29 & $5 / 23 / 73$ & 96.0 & 15.0 & 24.0 & 1.7 & 331.0 & 72.0 & 11.0 & 418.0 & 651.0 & 7.6 & 54 \\
\hline 30 & $9 / 5 / 73$ & 210.0 & 37.0 & 310.0 & 14.0 & 171.0 & 990.0 & 160.0 & $1,840.0$ & $2,440.0$ & 6.4 & 60 \\
\hline
\end{tabular}


pata for Selcetéd hells, Springs and

Related Data at Surface Kater Gaing Stations

Jemez Mountains Area, New Mexico

\begin{tabular}{|c|c|c|c|c|c|c|c|c|c|c|c|c|c|c|c|c|c|}
\hline 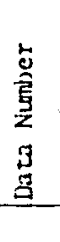 & . & $\stackrel{\mathscr{c}}{\mathrm{G}}$ & 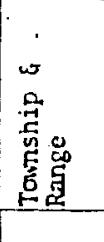 & 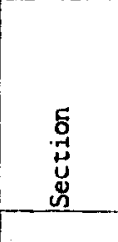 & 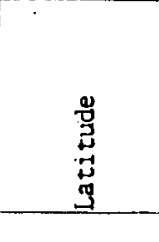 & 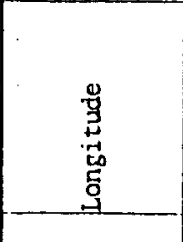 & 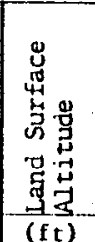 & 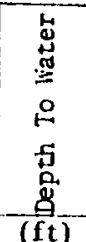 & 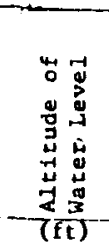 & 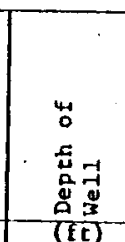 & 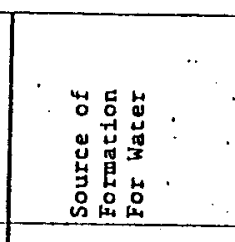 & 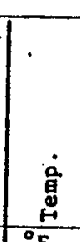 & 号 & 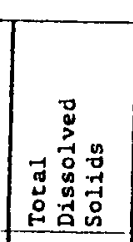 & 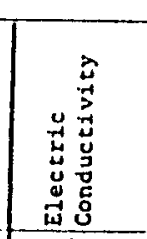 & 唡 & 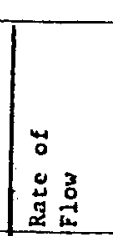 \\
\hline 1 & $\begin{array}{l}\text { Rio Grande At } \\
\text { Albuquerque }\end{array}$ & Surface & & & $\frac{35^{\circ} 05^{\prime} 21^{\prime \prime}}{35^{\circ} 15^{\prime} 66^{\prime \prime}}$ & $106^{\circ} 40^{\prime} 48^{\prime \prime}$ & $(\mathrm{ft})$ & & & & & ${ }^{\circ} \mathbf{F}$ & • & ppm & puhos & & $(\mathrm{gpm})$ \\
\hline$\frac{2}{3}$ & & $\frac{\text { Well }}{\text { hell }}$ & $\frac{12 N 2 E}{12 N 2 E}$ & $\frac{14.433}{25.421}$ & $-\frac{35^{\circ} 15^{\prime} 46^{\prime \prime}}{35^{\circ} 14^{\prime} 22^{\prime \prime}}$ & $\frac{106^{\circ} 42^{\prime} 05^{\prime \prime}}{106^{\circ} 40^{\prime} 42^{\prime \prime}}$ & $-5 \in 02$ & 637 & 4965 & & Santa Fe & .67 & $12 / 12 / 74$ & 265 & 367 & 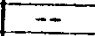 & 1.000 \\
\hline 5 & & $\begin{array}{l}\text { Well } \\
\text { Well }\end{array}$ & $\frac{1}{2} 1 \mathrm{~N} 2 \mathrm{E}$ & $\frac{23.421}{31.134}$ & $35^{\circ} 14^{\prime} 22^{\prime \prime}$ & $106^{\circ} 40^{\prime} 42^{\prime \prime}$ & $-\frac{5370}{5200}$ & -373 & 4997 & & Santa Fe & 55 & $12 / 12174$ & 267 & 352 & 7.4 & 650 \\
\hline 5 & & Well & $12 N 3 E$ & 30.121 & $35^{\circ} 14^{\circ} 46^{\prime \prime}$ & $106^{\circ} 40^{\prime} 06^{\prime \prime}$ & 5356 & 420 & 4936 & 350. & $\begin{array}{l}\text { Santa } \mathrm{Fe} \\
\text { Santa Fe }\end{array}$ & & $4 / 27 / 65$ & 343 & 501 & 7.8 & \\
\hline 6 & & hell: & $12 \mathrm{~N} 3 \mathrm{E}$ & 24.423 & & & 5030 & & & 96 & $\begin{array}{l}\text { Santa } \mathrm{Fe} \\
\text { Santa } \mathrm{Fe}\end{array}$ & 61 & $12 / 12 / 74$ & 255 & 348 & 7.5 & 1,000 \\
\hline 7 & & Well & $12 \mathrm{~N} 4 \mathrm{E}$ & 6.200 & & & 5050 & & & $=-$ & Santa $-\frac{F e}{\mathrm{Fe}}$ & & $2 / 26 / 65$ & 598 & 878 & 7.5 & \\
\hline$\varepsilon$ & & We11 & $12 \| 4 \mathrm{E}$ & 5.214 & & & 5040 & & & & Santa Fe & & $1 / 21 / 65$ & 457 & 666 & 7.5 & \\
\hline 9 & & We11 & $13 \times 3 \mathrm{E}$ & 18.31 & & & 5733 & & & 10,000 & & 81 & $9 / 25 / 74$ & 421 & 642 & -- & \\
\hline 10 & Jenez River Below & & & & & & & & & & & 90 & $8 / 26 / 72$ & 2,460 & 3,140 & 9.5 & \\
\hline 11 & Jemez Canyon Dam & $\begin{array}{l}\text { Surface } \\
\text { Surface }\end{array}$ & $13 N 4 E$ & 5.1 & $35^{\circ} 23^{\prime} 24^{\prime \prime}$ & $106^{\circ} 32^{\prime} 03^{\prime \prime}$ & & & & & & ' & & & & & \\
\hline 12 & & Surface & $13 \mathrm{~N} 4 \mathrm{E}$ & 1.234 & $35^{\circ} 23^{\prime} 10^{\prime \prime}$ & $106^{\circ} 31^{\prime} 45^{\prime \prime}$ & $\$ 100$ & & & & & & & & & & \\
\hline 13 & & We 11 & $13 N 4 E$ & 1.412 & & & $-\frac{5580}{5}$ & & & & Santa Fe & 78 & $9 / 25 / 74$ & 548 & 749 & 6.6 & \\
\hline 13.1 & & Well & $13 \mathrm{NE}$ & 1.421 & & & 5100 & 1 & & & Santa_Fe & 67 & $9 \longdiv { 2 5 / 7 4 }$ & 780 & 1,050 & -- & \\
\hline 14 & & Well & $14 \mathrm{NSE}$ & 19.221 & & & 5150 & & & & Santa $\mathrm{Fe}$ & 71 & $9 / 2 5 \longdiv { 7 4 }$ & 1,420 & 1,880 & 6.4 & \\
\hline 15 & San Isidro Group & Spring & $15 N 1 E$ & 8.32 & & & 5540 & & & 98 & Santa Fe & & $2 / 4 / 65$ & $(691)$ & 1,020 & 7.5 & \\
\hline 10 & Indian springs & Spring & $15 N 1 E$ & 9.2 & & & 5580 & & 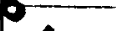 & & Wingate-Chinle & 86 & $9 / 15 / 24$ & 10,960 & $(16,800)$ & - & \\
\hline $1 i$ & & Weli & $15 N 1 E$ & 16.233 & & & 5530 & & & & Penn Rocks & 95 & $8 / 30 / 62$ & 3,470 & 5,680 & 8.0 & \\
\hline 18 & San Ysidro Group & Spring & $15 N 1 E$ & 10.14 & & & 5530 & & 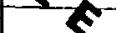 & & Chinle & 64 & $10 / 18 / 74$ & $\cdots$ & $\therefore 20,000$ & $\cdots$ & \\
\hline $19 \mathrm{~A}$ & & Spring & 15 NIE & 10.310 & & & 5530 & & & 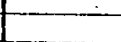 & Chinle & 68 & $9 / 15 / 24$ & 7,320 & 11,200 & -- & \\
\hline 19 & & Well & $15 N 2 \mathrm{E}$ & 22.400 & & & 5500 & & & 335 & Chinle & 63 & $5 / 2 / 73$ & 6.650 & 9.950 & 6.5 & \\
\hline 20 & & Well & $15 \mathrm{ME}$ & 12.431 & & & 5750 & & & -2 & Santa Fe & & $2 / 27165$ & 330 & 519 & 7.6 & \\
\hline$? 1$ & & We 11 & $1515 \mathrm{E}$ & 13.330 & & & 5170 & & & 82 & Santa Fe & -63 & $4 / 4 / 74$ & 332 & 490 & 7.9 & \\
\hline$-2=$ & & Spring & $16 \mathrm{~N} 1 \mathrm{~W}$ & 29.230 & & & 5830 & & & & Santa Fe & & $-1 / 21 / 65$ & $(872)$ & 1.190 & 7.3 & \\
\hline 23 & & Spring & 160116 & 1.421 & & & 6020 & & & & Chinle & 70 & $6 / 5<73$ & 7,760 & 10.100 & 8.5 & 2 \\
\hline $2+$ & & Spring & $16 N 1 E$ & 6.321 & & & 6360 & & & & Ch!nle. & 126 & $-6 / 5 / 73$ & 11.100 & 15.700 & 6.8 & 85 \\
\hline 25 & Hot hell & Well & 16NIH & 1.243 & & & 602 & & & & Chinle & 79 & $10 \angle 2173$ & 529 & 960 & 7.2 & \\
\hline 26 & B ase-an hell & Well & & & $35^{\circ} 37^{\prime} 04^{\prime \prime}$ & $106^{\circ} 52^{\prime} 54^{\prime \prime}$ & 5900 & & & $-\overline{550}$ & & 129 & $3 / 16 / 64$ & 11.000 & 15,300 & 7.3 & \\
\hline $2 \pi$ & Perasco Spring & Spring & $16 \mathrm{NIE}$ & 20.32 & & & 6000 & & & & & 115 & $2 / 29 / 24$ & 11.120 & $\ldots$ & $=$ & 2.450 \\
\hline 23 & tog spring & Spring & $16 N 1 E$ & 5.244 & & & 7175 & & & & Pre-cambrian & 70 & $2 / 14 / 24$ & 7.510 & $(11,500)$ & $=$ & \\
\hline 29 & & Spring & $16: 1 \mathrm{E}$ & 3.441 & & & 7000 & & & & $\begin{array}{l}\text { Pre-cambrian } \\
\text { Abo }\end{array}$ & & $5 / 23 / 73$ & 310 & 487 & 2.6 & \\
\hline 30 & & Spring & $16 N 1 E$ & 25.244 & & & 5700 & & & & Choo & & $5 / 23 / 73$ & 418 & 651 & 7.6 & \\
\hline 31 & & Spring & $16 \mathrm{~N} 2 \mathrm{E}$ & 30.313 & & & 5600 & & & & \begin{tabular}{|l|} 
Chinle \\
Alluvial
\end{tabular} & & $8 / 5 / 73$ & -1.840 & 2,440 & 6.4 & \\
\hline 32 & & Spritg & $16 \times 2 \mathrm{E}$ & 20.332 & & & 5540 & & & & $\begin{array}{l}\text { Alluvial } \\
\text { Chinle }\end{array}$ & 66 & $2 / 5 / 73$ & 2,350 & 3,190 & 7.0 & \\
\hline 33 & & Spring & $16 \times 2 \mathrm{E}$ & 18.214 & & & 5860 & & & & $\frac{\text { Chingle }}{\text { Abo }}$ & 59 & $5 / 24 / 73$ & 4.150 & 6.420 & 6.4 & \\
\hline 36 & Owl Spring & Spring & $1692 \mathrm{E}$ & 7.441 & & & 5780 & & & & $\frac{\text { Abo }}{\text { Penn Rocks }}$ & 66 & $5 / 24 / 73$ & 674. & 1,070 & 1.0 & \\
\hline 35 & & Spring & $16 \mathrm{~N} 2 \mathrm{E}$ & 7.432 & & & 5850 & & & & $\begin{array}{l}\text { Penn Rocks } \\
\text { Madera }\end{array}$ & & $5 / 1 / 53$ & & 1.270 & & 32 \\
\hline 36 & & hell & $16 \mathrm{~N} 2 \mathrm{E}$ & 16.411 & & & 5580 & & & 81 & $\begin{array}{l}\text { Madera } \\
\text { Alluvial }\end{array}$ & 61 & $5 / 24 / 73$ & 482 & 788 & 2.3 & \\
\hline & & & & & & & & & & & Alluvial & & $1 / 19 / 65$ & 589 & 946 & 7.6 & \\
\hline
\end{tabular}




\author{
REPORT NO. 15 \\ EXECUTIVE SUMMARY \\ SUMMARY SHEETS FOR \\ BACA WELLS NUMBER 1 TO 3
}

FROM A REPORT

Prepared By

THE BACA LAND AND CATTLE CO.

DUNIGAN ENTERPRISES, INC.

ABILENE, TEXAS

1971

Summary Prepared By

WESTEC SERVICES, INC.

ALBUQUERQUE, NEW MEXICO

MAY 1980 


\begin{abstract}
This report provides a summary of drilling data on Baca Wells Number 1 to 3 , and conclusions drawn from that data. As a part of the summary, a brief history is given on the three wells and information is also given which lead to the drilling of Baca Well Number 4. Information is given on temperatures at depth and lost circulation depths. This report is a section of a larger report. The title and author of the original report is not known, however, the author is assumed to be Baca Land and Cattle Co. (BLCC) since Wells Number 1 to 4 were drilled by BLCC.
\end{abstract}




\section{$1.0 \quad$ INTRODUCTION AND SCOPE}

The preceding section of the original report was devoted primarily to a tabulation of facts with as little speculative material as possible. With the exception of well data, this section is more interpretive and leads to a generalized model of the Valles Caldera hydrothermal system. This section includes descriptive summaries of Baca Wells 1 through 4 and the methods used to complete them. Temperature and casing data are also summarized graphically.

\section{SUMMARY AND CONCLUSIONS}

The general conclusion proposed is that the Valles Caldera is an excellent prospect for geothermal development including the production from vapor-dominated, and liquid-dominated reservoirs. The general model consists of a high heat flow area, the caldera, situated in the path of a deep groundwater system tending to flow from north to south across the caldera. Heat flow near the center of the caldera is sufficient to cause boiling and separation of vapor-phase water. This area is prospective for the production of dry steam. The most likely area for production from a liquid-phase reservoir, which requires a potentiometric surface near the earth's surface, and a porous and permeable reservoir, is immediately north of the vapor-phase prospective area. 
REPORT NO. 16

EXECUTIVE SUMMARY

SUMMARY SHEETS FOR

BACA WELLS NUMBER 4 TO 16

FROM A REPORT

Prepared By

UNION GEOTHERMAL DIVISION

UNION OIL COMPANY OF CALIFORNIA

LOS ANGELES, CALIFORNIA

Sum mary Prepared By

WESTEC SERVICES, INC.

ALBUQUERQUE, NEW MEXICO

MAY 1980 


\begin{abstract}
This report contains two tabular summaries of some of the data collected on Baca Wells 4 through 16. The information contained in this report is: well pad elevation, drilled depth, drilling medium at depth, entry or lost circulation depths, depth of 9-5/8 inch casing, depth of 7 inch slotted and solid liner, $450^{\circ} \mathrm{F}$ isotherm depth and elevation, and depths of lithological layers.

Copies of the 3 page report may be difficult to read because of poor original quality. More extensive information is available in Reports No. 17 through 20.
\end{abstract}


REPORT NO. 17

EXECUTIVE SUMMARY

WELL SUMMARY REPORTS AND

DRILLING HISTORIES

BACA WELLS NUMBER 4 TO 16

FROM A REPORT

Prepared By

UNION GEOTHERMAL DIVISION

UNION OIL COMPANY OF CALIFORNIA

LOS ANGELES, CALIFORNIA

Summary Prepared By

WESTEC SERVICES, INC.

ALBUQUERQUE, NEW MEXICO

MAY 1980 


\begin{abstract}
This report contains the completed day-by-day drilling reports, completion data sheets and graphic representations of completions for Baca Wells 4 through 16. The summaries, both graphic and descriptive, contain drilling methods, historic problems during completion, dates of drilling commencement and completion and casing and cement schedules.
\end{abstract}


EXAMPLES OF REPORT CONTENT 


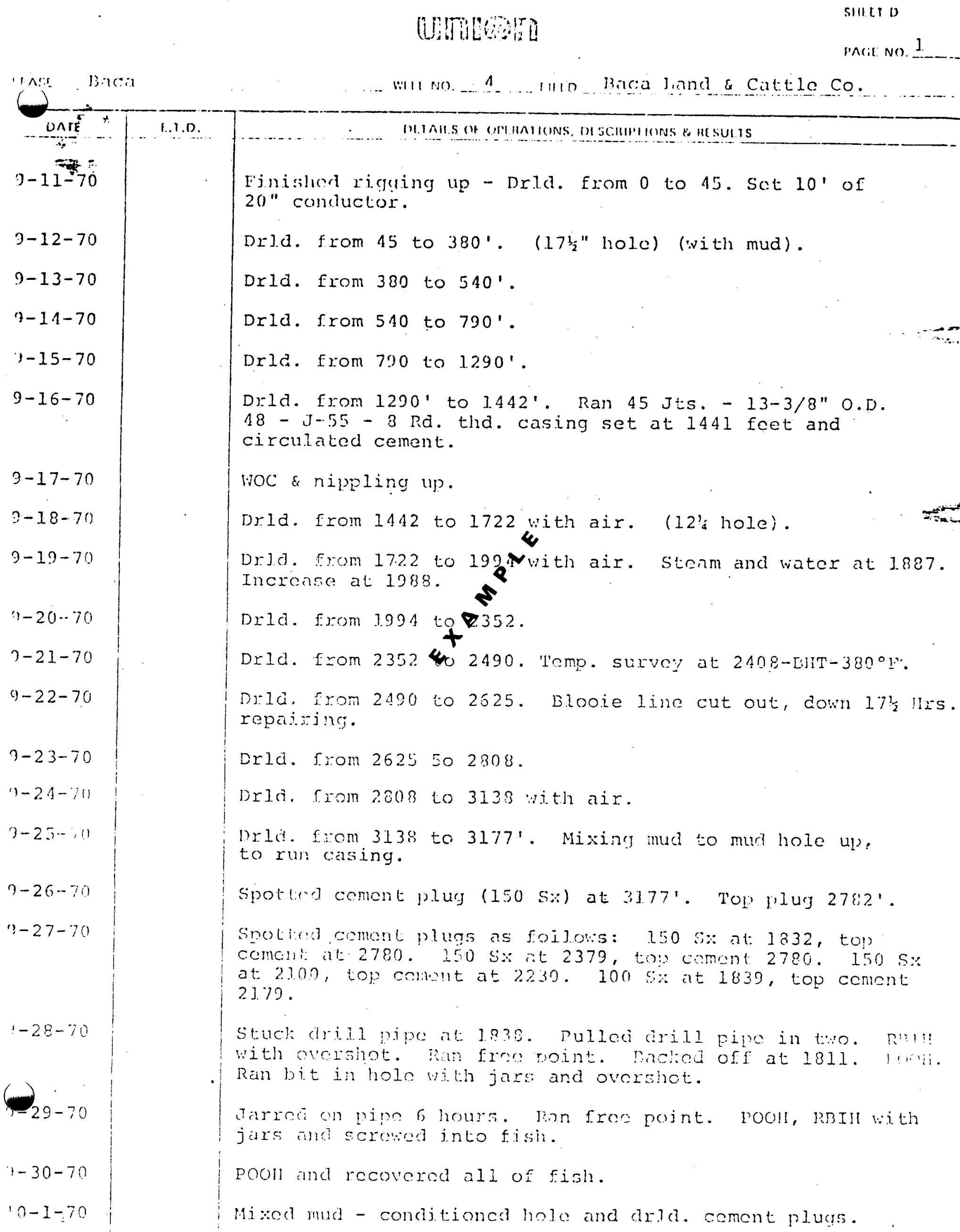

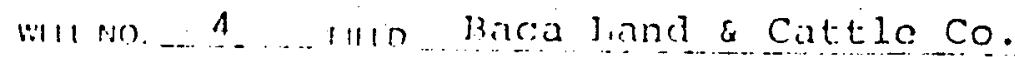

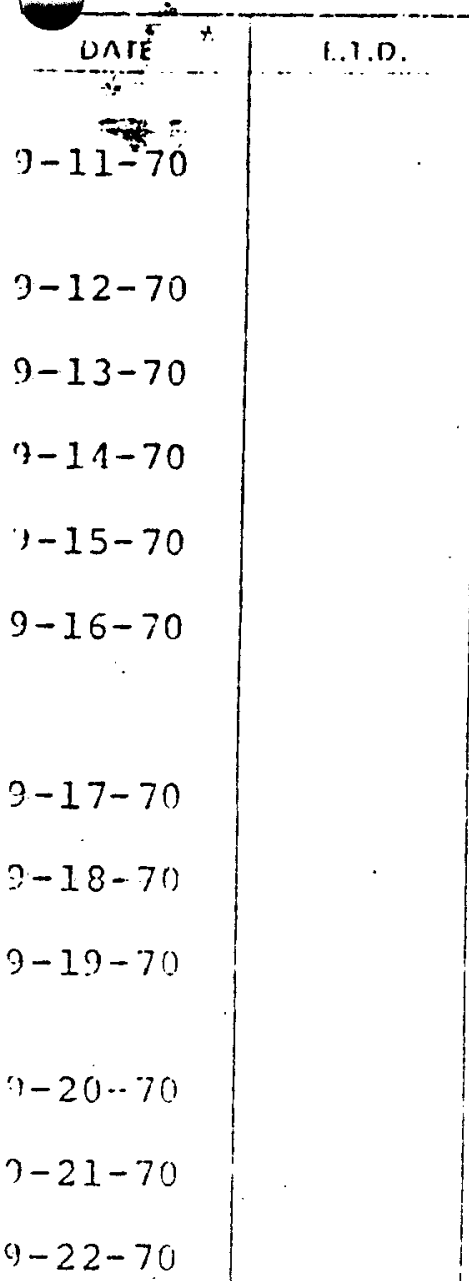

Finislior riguing up - Drla. Exom 0 to 45. Sot 10' of $20 "$ comeluctor.

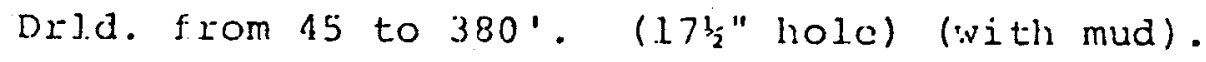

Drld. from 380 to $540^{\prime}$.

Drld. from 540 to $790^{\prime}$.

Drld. From 790 to $1290^{\prime}$.

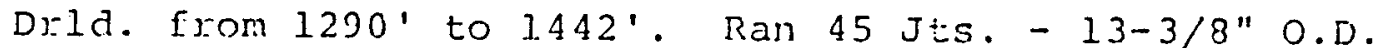
$48-J-55-3$ Rd. thd. casing set at 1441 feet and circulated cement.

WOC \& nippling up.

Drld. From 1442 to 1722 with air. (12! hole).

Drd.d. from 17.22 to 193 Wwith air. Stenm and water at 1.887 . Incronse at 1388.

Drid. from 1994 to $\mathbf{2 3 5 2}$.

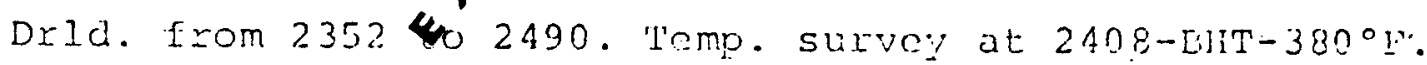

Drid. from 2490 to 2625. Blooie line cut out, down 17! IIrs. repaitinge

Drla. from 2625 50 2308

Drla. Fom 2808 to 3133 ath air.

Dreld. Fon 3138 to $3177^{\prime}$. Mixing mud to mud hole up,

to rur casing.

spotted comont plug (150 5x) at 3177'. Top plug $2787^{\prime}$.

Snotirn comont plugs as foijons: $2506 \%$ at: 1332 , top comchli: at 2780 . $250 \quad 5 \%$ at 2379 , top comont 2780 . 150 sx at 2.100, top comont at 2230. $100 \mathrm{~s}$ at 1839 , top conent 2].79.

Stuck drill pipe at 1838. Pullod arill pipe in toro. Ryll with oveshot. an frro roint. racliod off at 1811 . Whe Rein bit in hole vith jars and overehot.

Tarred on pipo 6 hours. Jan fros point. pooll, RBIH with jars anet scrowad juto fisin. 


\section{GTOTHIIMMAL RE:SOURCES WELL SUMMARY RETORT}

Ipeiator Infon 01l Company of Callfornia.

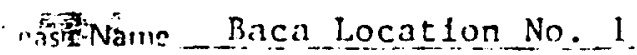

Init Letter _._.

imservoir Redondo Creek

12
Addicss Mtn._Route Box 76, Jemez.Sprinss, NM 871 Woll No. BacaNo Two.

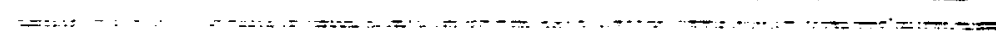

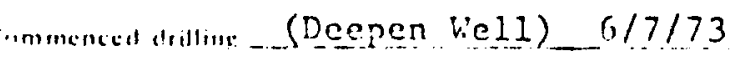

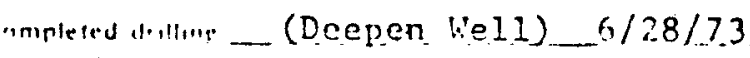

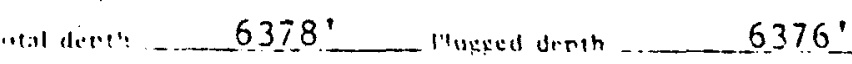

.. None

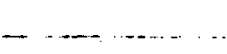

$19 N$

County Sandoyal

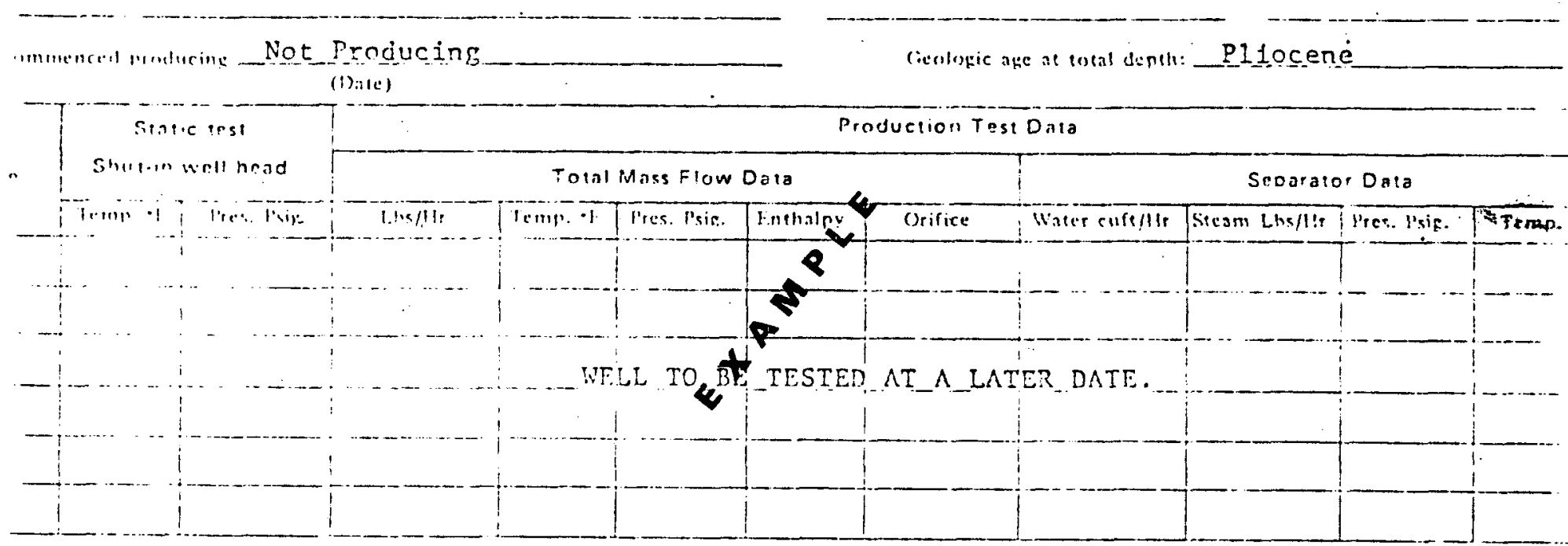

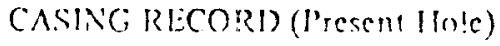

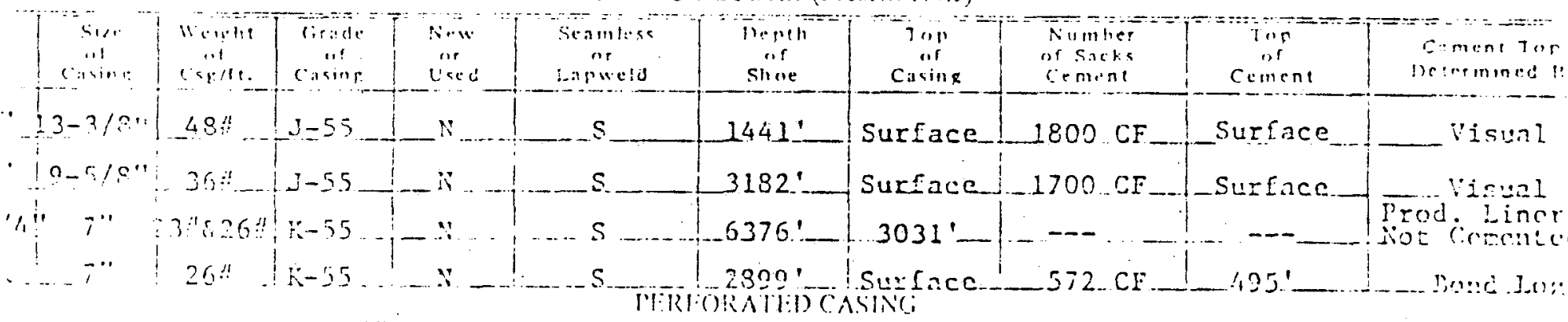

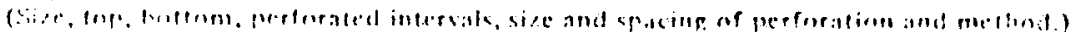

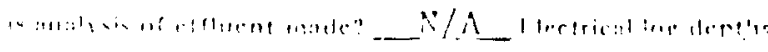
$\because / \wedge$ Tremnierndure lag deptles $\because i$

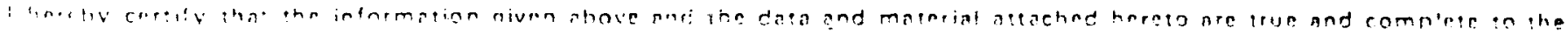
bmet n! my loowladar and prlin? 


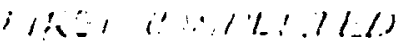
$1 i \cdot 12$

REMEDIAL WURK (. 28-;

$$
0^{\circ}-200^{\circ}
$$

GROUND ELEV. $9318^{\circ}$

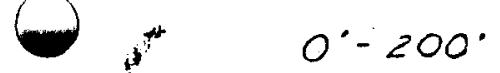

CALOERA FILL

$+5$

$\therefore 00^{\circ}-5950^{\circ}$

EANCELIER TUFF

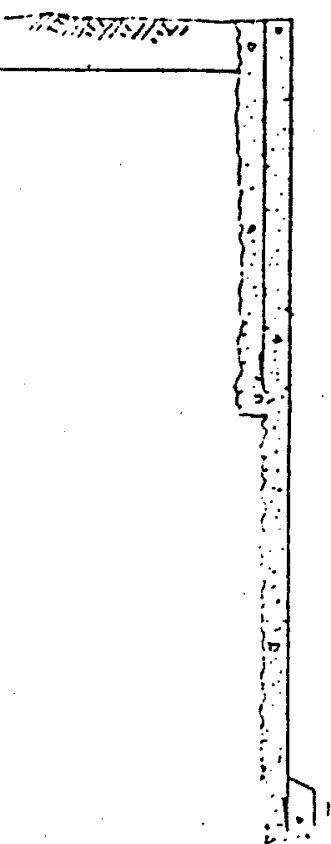

$17.5^{\circ}$ HOLE

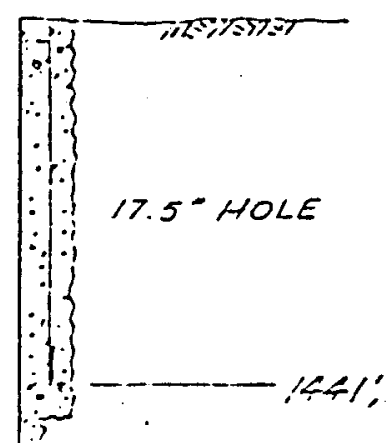

$153 / 8$

3
$\vdots$
$\vdots$
$\vdots$
$\vdots$
$\vdots$
$\vdots$
$\vdots$

SO31:TOP 7"LINER'

318:; O5\%", J6- CASING

CMT'O $\mathrm{W} / 1700$ FT. 3

\section{0 คT.?}

8.75": $70 L E$

$|1,1|$

1,1

$\mid 1,1$

$\mid 11$

$|1,1|$

$\mid 1,1$

S980 - T:D PALIZA GANYON ANDESITE

$6376 ; \%, 23 ; \therefore 6 *$

$$
\begin{aligned}
& \text { SLOTRO EMER } \\
& \text { S:075 50:5'- 0375 }
\end{aligned}
$$$$
1
$$

T.0. $6570^{\circ}$

STIAI E WATER ENTRIES

2000

2115

$\therefore<00$

$2 \div 90$

2501

2625

$\because \because 00$

$3150-31 \%$

$\rightarrow>10$

+ $\therefore 2-x / 3$

$\therefore: y 5$

$\therefore \because 3:=000$

(1)

BY: ….C. DATE: $11-1 \% 75$ SCALE: "TUCO DRANING NUMBER 
REPORT NO. 18

EXECUTIVE SUMMARY

LITHOLOGY LOGS

BACA WELLS NUMBER 4 TO 16

FROM A REPORT

Prepared By

UNION GEOTHERMAL DIVISION

UNION OIL COMPANY OF CALIFORNIA

LOS ANGELES, CALIFORNIA

Summary Prepared By

WESTEC SERVICES, INC.

ALBUQUERQUE, NEW MEXICO

MAY 1980 


\begin{abstract}
This report contains the lithological logs completed by Union Oil Company of California geologists for Baca Wells 4, 5A, 6, and 8 through 16. The quality of the duplication of the logs vary depending on the quality of the original.
\end{abstract}


LIST OF LITHOLOGICAL LOGS CONTAINED IN THE REPORT

BACA WELL NO.

4

$5 \mathrm{~A}$

6

8

9

10

11

12

13

14

15

16 $\underline{\text { DEPTH (FT.) }}$

5080-6378*

0-6973

0-3715

$0-4369$

0-3520

2710-5303*

0-5940

0-6814

0-9175

0-8228

$0-6824$

0-5505

0-7002

* Data was collected during deepening or redrilling of well. 
REPORT NO. 19

EXECUTIVE SUMMARY

TEMPERATURE AND PRESSURE SURVEYS

BACA WELLS NUMBER 4 TO 8 AND 10 TO 16

FROM A REPORT

Prepared By

UNION GEOTHERMAL DIVISION

UNION OIL COMPANY OF CALIFORNIA

LOS ANGELES, CALIFORNIA

Summary Prepared By

WESTEC SERVICES, INC.

ALBUQUERQUE, NEW MEXICO

MAY 1980 


\section{ABSTRACT}

This report consists of an extensive file of temperature and pressure surveys conducted beginning immediately after well completion and continuing in most cases, for several years. The report also contains the daily $\log$ of the well driller for Baca Wells Number 5 and 5A. The report is separated into 12 sections. The surveys vary in quantity of data and detail. In most cases the chronology of data begins soon after well completion and continues for between several months and several years. The most recent data in the report was collected in October 1976. 


\title{
LISTING OF SURVEYS CONTAINED
}

IN THE REPORT

\section{(All surveys are temperature and pressure except as noted)}

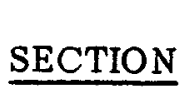

\author{
BACA WELL \\ NUMBER
}

a

b

c

d

e

f

g

h

i

j

k

1

4

5

$5 *$

6

$7 \& 8$

10

11

12

13

14

15

16

\begin{tabular}{|c|c|}
\hline \multicolumn{2}{|c|}{ (MONTH/YEAR) } \\
\hline $\begin{array}{c}\overline{\text { FIRST }} \\
\text { SURVEY }\end{array}$ & $\begin{array}{c}\text { LAST } \\
\text { SURVEY }\end{array}$ \\
\hline $10 / 72$ & $10 / 76$ \\
\hline $10 / 72$ & $6 / 76$ \\
\hline $7 / 71$ & $9 / 71$ \\
\hline $10 / 72$ & $9 / 75$ \\
\hline $7 / 74$ & $9 / 74$ \\
\hline $10 / 73$ & $10 / 76$ \\
\hline $12 / 73$ & $9 / 76$ \\
\hline $7 / 74$ & $9 / 76$ \\
\hline $11 / 74$ & $9 / 76$ \\
\hline $2 / 75$ & $8 / 76$ \\
\hline $6 / 75$ & $10 / 76$ \\
\hline $7 / 75$ & $7 / 76$ \\
\hline
\end{tabular}

*Drillers daily log of Baca Well \#5 and 5A. 


\author{
REPORT NO. 20 \\ EXECUTIVE SUMMARY
}

\author{
ELECTRIC LOGS FOR
}

BACA WELLS NUMBER 10 TO 14

FROM A REPORT

Prepared By

UNION GEOTHERMAL DIVISION

UNION OIL COMPANY OF CALIFORNIA

LOS ANGELES, CALIFORNIA

Summary Prepared By

WESTEC SERVICES, INC.

ALBUQUERQUE, NEW MEXICO

MAY 1980 


\begin{abstract}
This report is a compilation of early electric wireline logs run in Baca Wells Number 10 to 14. Most of the logs were run on well completion. The logs included in this compilation may represent only a portion of the logs run in the wells, and some may have been updated by more recent logs. The types of logs included are: temperature, compensated neutron/gamma-gamma density, gamma, neutronneutron, sonic cement bond, and casing inspection caliper. It should be noted that these are standard electric well logs, however, well log interpretation expertise is required for their use.
\end{abstract}




\section{LIST OF LOGS INCLUDED}

IN THE REPORT

\section{BACA WELL}

NUMBER

10

10

10

12

12

13

13

13

14

14
TYPE LOG

Gamma

Temperature ( 3 runs)

Sonic Cement Bond

Temperature

Casing Inspection Caliper

Neutron-Neutron (2 runs)

(Dukil Induction Laterology)

Compensated Neutron-Density

Sonic Cement Bond

Compensated Neutron-Density

Temperature
DATE LOGGER

$9 / 73 \quad 1$

$9 / 73 \quad 1$

$9 / 73 \quad 1$

$7 / 74 \quad 2$

$7 / 76 \quad 3$

$8 / 74,10 / 74 \quad 1$

$10 / 74$

$10 / 74 \quad 1$

$2 / 75 \quad 1$

$10 / 75 \quad 1$

\section{Logs Run By:}

1 - Schlumberger

2 - Dresser-Atlas

3-GO Wireline Services 
REPORT NO. 21

EXECUTIVE SUMMARY

HYDROTHERMAL GEOLOGY OF THE

VALLES CALDERA, NEW MEXICO

FROM A REPORT

Prepared By

R.F. Dondanville

UNION GEOTHERMAL DIVISION

UNION OIL COMPANY OF CALIFORNIA

LOS ANGELES, CALIFORNIA

JUNE 1971

Summary Prepared By

WESTEC SER VICES, INC.

ALBUQUERQUE, NEW MEXICO

JUNE 1980 


\begin{abstract}
The purpose of this report was to gather together and summarize all available hydrothermal data on the Valles Caldera in northern New Mexico, and secondarily, to present a tentative model of the hydrothermal system for use as a basis for geothermal exploration. The studies have ranged from the academic pursuits of the United States Geological Survey to private attempts to win commercial geothermal resources. Every attempt was made to utilize reliable data.
\end{abstract}




\subsection{INTRODUCTION AND SCOPE}

The primary purpose of this report is to summarize the available knowledge of the Valles Caldera hydrothermal system at the time of the report, and secondarily, to present a very tentative model of the hydrothermal system for use as a basis for geothermal exploration. Over a series of years, many man-hours of study have been devoted to the Valles Caldera. The studies have ranged from the academic pursuits of the United States Geological Survey to private attempts to win commercial geothermal resources. This report is simply an attempt to bring together the pertinent, but scattered data generated by other workers. With the exception of the proposed model, there is little original work in this report.

The sources of data for this report were published geological reports, unpublished United States Geological Survey information from the files of the Baca Land and Cattle Company, drilling reports and geological reports of the geothermal wells, and geologic excursions in the Jemez Mountains.

The author has intentionally not elaborated on the topies of stratigraphy and structure. Those subjects had been well covered by the U.S.G.S. map of the Jemez Mountains by Smith, Bailey and Ross. The copy of that map included in the report should be considered an integral part of this report.

SUMMARY AND CONCLUSIONS

The Valles Caldera, sometimes called Jemez Caldera, is located in the Jemez Mountains, a complex volcanic highland of Pliocene and Pleistocene age, about 55 miles north of Albuquerque in north-central New Mexico. The caldera is circular in shape, 12 to 15 miles in diameter, and 500 to 2000 feet deep. The caldera is a relatively young structure, originating about 1.1 million years ago following an enormous eruption of rhyolitic ash and pumice. The caldera is currently in a stage of hot spring activity, although the periodicity of rhyolitic volcanism does not preclude future eruptions.

Hot springs and warm weather wells are generally distributed over several hundred square miles in the Jemez Mountains, indicating a geothermal anomaly of regional scope. The geothermal anomaly culminates in the Valles Caidera, most obviously in the western half, where a maximum temperature of 532F has been measured in the Baca No. 4 geothermal well. Because the structure of the caldera is analogous to a pot on a stove, high subsurface temperatures are probably available everywhere within the 150 square mile caldera, and certainly everywhere within the central 100 square miles.

The deep groundwater system underlying the Valles Caldera is essentially a single unit which can be described simply as the deep flow of 
water from the San Pedro and Jemez Mountains into the Rio Grande drainage basin. In addition to subsurface pressure measurements, ionic and isotopic characteristics of the hydrothermal waters can be used to trace water flow in the hydrothermal system. The potentiometric surface of the deep groundwater system is near the surface in the northern half of the caldera and over a thousand feet below the surface in the center of the caldera.

Knowing the subsurface pressure-temperature relationships, a tentative model of the Valles Caldera hydrothermal system is proposed: relatively cool water enters the very hot caldera from the north. As the water flows through the subsurface the enthalpy increases, and near the center of the caldera boiling begins. In the vicinity of the Baca No. 4 well, boiling of the deep water has led to formation of a vapordominated reservoir about 2500 feet thick. South of the Baca No. 4 location, given a continuing addition of heat, the vapor-dominated reservoir should be thicker.

The above considerations lead to the conclusion that about 40 square miles in the southern half of the Valles Caldera are prospective for drysteam production. Liquid-phase reservoirs with temperatures at least as high as the vapor-dominated reservoirs may be prospected for in the northern half of the caldera where the water table is near the surface. Surface manifestations (hot springs, altered rock) of the hydrothermal system are absent in the eastern half of the Valles Caldera and in the adjoining Toledo Caldera. The lack of surficial expression is due to topography and near-surface geology. At depth, the Toledo Caldera and eastern Valles Caldera are fully as prospective as the western Valles Caldera. 
I. SUMMARY 1

II. INTRODUCTION 3

III. GEOLOGIC SETTING 4

A. Regional Geology and Geography 4

B. Geologic History 5

IV. HYDROTHERMAL GEOLOGY 6

A. Volcanic Setting 6

B. Temperature Distribution 6

C. Fluid Pressure Distribution and Groundwater Flow

D. Water Chemistry 14

E. Hydrothermal Alternation 20

V. GEOPHYSICAL SURVEYS

A. Gravity Survey $\quad 26$

B. Magnetic Survey $\quad 27$

C. Seismic Noise 27

VI. GEOTHERMAL ENERGY POTENTIAL OF THE VALLES CALDERA $\quad 29$

A. General Statement $\quad 29$

B. Summary of Wells Drilled to Date 29

C. Model of the Valles Caldera Hydrothermal System 33

VII. APPENDICES
A. References
B. Chemical Anaiyses of Selected Waters
C. Chemical and Physical Analyses of Rocks from the Baca No. 4 Well
D. Concise Geothermal Well Description

INCLUDED IN POCKET

United States Geological Survey Map I-571:

Geological Map of the Jemez Mountains

Map I Geothermal Features of the Jemez Mountains

Map II Potentiometric Surface of Deep Groundwater

System, Jemez Mountains
Map III Geothermal Prospect Areas in the Valles

Caldera 
REPORT NO. 22

EXECUTIVE SUMMARY

AIRBORNE INFRARED

GEOTHERMAL EXPLORATION - VALLES CALDERA

JEMEZ MOUNTAINS, NEW MEXICO

FROM A REPORT

\author{
Prepared For \\ Prepared By \\ UNION GEOTHERMAL DIVISION \\ EARTH RESOURCE OPERATIONS \\ UNION OIL COMPANY OF CALIFORNIA \\ NORTH AMERICAN ROCKWELL \\ LOS ANGELES, CALIFORNIA \\ CORPORATION \\ FEBRUARY 1972
}

Summary Prepared By

WESTEC SERVICES, INC.

ALBUQUERQUE, NEW MEXICO

JUNE 1980 


\begin{abstract}
This document is a final report to Union Oil Company of California. The report summarizes the results of an airborne infrared thermal mapping survey of the Valles Caldera, New Mexico geothermal area. The results are primarily a discussion and interpretation of the infrared imagery collected during predawn flights conducted on November 12, 1971, by the North American Rockwell Corporation, Earth Resources Operations. The report is well organized and documented. Many of the figures, however, are multi-generation copies of color photographs, and may be difficult to interpret.
\end{abstract}


An airborne, infrared thermal mapping survey was flown over the Valles Caldera area, New Mexico, on November 12, 1971, in order to locate and delineate potential geothermal energy regions. Prior to the actual flight operations, several days were spent in the area planning the flight lines, placing flight line markers, and becoming familiar with the local geology. Thermometric probe temperatures were taken at known geothermal areas to be used as ground truth in remote sensor imagery interpretation. During the predawn period of November 12, 1971, a series of infrared thermal scanner flights was made over the Valles Caldera, while ground crews directed the aircraft by beacon lights and radio. Simultaneously with the overflights, terrain surface temperatures were sampled to be utilized as additional reference points. The $70 \mathrm{~mm}$ strip infrared thermal imagery was developed in the field to insure coverage of the area of interest. The imagery appeared to show many geothermal areas in detail for later laboratory and exploration analysis. Laboratory interpretation and enhancement was performed at the North American Rockwell (NR), Downey, California facilities.

On December 17,1971 , a preliminary briefing on the survey results was held at the Union Oil Company's Los Angeles office. At that meeting the preliminary geothermal anomalies map developed by North American Rockwell was discussed in detail. From these discussions, a decision was made on the locations of potential geothermal anomalies which were enhanced on the NR data color processor. The resulting data, imagery and color enhancements are included in this final survey report.

In addition to the above contractual survey and interpretation requirements, NR performed a high altitude photographic flight over the area. On November 11, 1971, the NR Sabreliner obtained black and white photos of the Valles Caldera from 43,650 feet above MSL with a T-11 aerial camera. The resulting photographs are included with this report. They were utilized for accurately locating geothermal anomalies and are included as supplemental material.

\subsection{SUMMARY AND CONCLUSIONS}

The flight operations for the Airborne Infrared Geothermal Survey of the Valles Caldera, New Mexico area were conducted during the predawn hours the morning of November 12, 1971. The Twin Beech survey aircraft maintained an altitude of 14,000 feet (MSL) throughout all the data acquisition runs. A total of 14 data flight lines was fiown; this total is listed on Table 1 . The flight line number designations and direction each line was flown are indicated on the table. Aircraft takeoff from Santa $\mathrm{Fe}$ Airport was at 03:15 for the first sortie, which covered the initial calibration passes over the survey area prior to flying the first nine (9) runs. The aircraft returned to Santa Fe Airport 
to replenish the IR scanner detector with liquid nitrogen at approximately 05:30 and returned to the survey area for the second sortie at 06:19 to complete the last five (5) runs by approximately 07:00. Flight line numbers 1 through 12 flown in a north-south direction provides complete coverage of the survey area. Flight line number one-prime borders the eastern survey boundary. Flight line number eight-prime (flown from the southwest corner of the area to the northeast corner) basically traverses the area diagonally. Flight lines 1 through 9 were flown with the aid of ground lights positioned along Highway 4 in the south portion of the survey area and along a private road that runs eastwest in the northern part of the area. The remaining flight lines were flown with the aid of first light of dawn.

A photo reduction of the infrared thermal imagery mosaic is shown in Figure 1. True north is oriented toward the top of the photo. Figure 2 shows the flight lines as they were actually flown superimposed over a base map of the survey area. In addition to the flight line locations, the figure also indicates the principal points (central points) of each of the 9-inch by 9-inch high altitude photographs taken on November $11,1971$. The high altitude photography was made from an altitude of 43,650 feet above sea level using the North American Rockwell Sabreliner survey craft. Further discussion regarding the camera coverage is contained in a later section entitled Aerial Photography.

The authors present detailed conclusions on the location and extent of suspected geothermal anomalies. However, they point out that each suspected anomaly should be investigated in the field before they can be considered confirmed. 


\section{TABLE OF CONTENTS OF THE REPORT}

$\underline{\text { TITLE }}$

$\underline{\text { PAGE }}$

Introduction

Summary of Flight Operations

Geologic Setting of the Valles Caldera

Image Interpretation

Aerial Photography

Recommendations .

References

\section{APPENDIX}

I Data Acquisition

44

II Automatic Data Reduction

48

III External Effects on IR Measurements

49

IV Sources of Measurement Error

50

V Transmittal of Data

51 
Infrared Thermal Imagery Mosaic 5

Flight Line Location Map 6

Geologic Map of the Valles Caldera $\quad 8$

Model of Rio Grande Rift 10

Geothermal Anomalies Map 12

Data Color Enhancement $2.1 \quad 15$

Data Color Enhancement 3.1 - 3.5 16

Data Color Enhancement 3.5 - 3.8 17

Data Color Enhancement 3.6 - 3.10 18

Data Color Enhancement 4.1-4.3 19

Data Color Enhancement 4.2 - 4.4 20

Data Color Enhancement 5.1A 21

Data Color Enhancement 5.1 22

Data Color Enhancement 5.2 - 5.3 23

Data Color Enhancement J.4, 5.6 24

Data Color Enhancement $6.1-6.2$

Data Color Enhancement $6.1-6.3 \quad 26$

Data Color Enhancement $6.4,5.4 \quad 27$

Data Color Enhancement 7.1 - 7.4 28

Data Color Enhancement 7.3 - 7.5 29

Data Color Enhancement 7.5 - 8.5 30

Data Color Enhancement $8.1 \quad 31$

Data Color Enhancement 8.1 - 8.3 32

Data Color Enhancement 8.2 - 8.4, 9.3A - 9.6 33

Data Color Enhancement 8.5 - 8.6, 9.6 - 9.12

Data Color Enhancement 9.3A - 9.7 35

Data Color Enhancement 9.7 -9.12 36

Data Color Enhancement $10.1-10.3 \quad 37$

Data Color Enhancement 10.4-10.5 38

Data Color Enhancement 10.6-10.8 39

Aerial Photo Mosaic - Valles Caldera 41

Thermal Mapper 45

Collecting Optics Schematic $\quad 46$

LIST OF TABLES IN THE REPORT

Table $\quad$ Page

$1 \quad$ Flight Line Sequence $\quad 4$ 
REPORT NO. 23

EXECUTIVE SUMMARY

\title{
ELECTRICAL RESISTIVITY SURVEY IN THE \\ VALLES CALDERA, SANDOVAL COUNTY, NEW MEXICO
}

FROM A REPORT

\author{
Prepared For \\ UNION GEOTHERMAL DIVISION \\ UNION OIL COMPANY OF CALIFORNIA \\ LOS ANGELES, CALIFORNIA
}

Prepared By GROUP SEVEN, INC. GOLDEN, COLORADO JULY 1972

Summary Prepared By

WESTEC SERVICES, INC.

ALBUQUERQUE, NEW MEXICO

JUNE 1980 


\begin{abstract}
Group Seven, Inc. carried out an electrical resistivity survey of the Valles Caldera area in north-central New Mexico for the purpose of delineating potentially productive geothermal reservoirs. An area of moderately low resistivity (less than $20 \mathrm{ohm}$-meters, with conductance of 140 to 200 mhos) was recognized along the western edge of the prospect, extending outside of the prospect. This trend of low resistivity runs southwestward from Valle Seco, through Mushroom Basin to the vicinity of Horseshoe Spring, and another smaller area of very low resistivity at the mouth of Alamo Canyon. This first area of low resistivity exhibits a pattern typical of geothermal system in other parts of the world. Depth to non-porous basement appears to be about 1.5 kilometers in the Sulfur Creek area, based on both dipole mapping data and electromagnetic sounding data.
\end{abstract}


Group Seven, Inc. carried out an electrical resistivity survey of the Valles Caldera area in north-central New Mexico for the purpose of evaluating a geothermal system in terms of its potential for generating electric power. The survey was carried out on behalf of the Union Oil Company of California. Field operations were initiated on May 8, 1972 and completed on June 13, 1972.

The Valles Caldera prospect occupies an area some 12 miles square in Sandoval County, New Mexico, just west of the city of Los Alamos. The area is included on two U.S. Geological Survey 15-minute topographic quadrangle maps, the Jemez Springs quadrangle and the Frijoles quadrangle. The area is also covered by $7 \frac{1}{2}$ minute topographic quadrangle maps, but the 15-minute maps were used as the base for presenting the results of the electrical survey.

The electrical survey undertaken by Group Seven, Inc. consisted primarily of direct-current dipole mapping surveys, augmented with Schlumberger direct-current soundings and electromagnetic soundings. The dipole mapping surveys were intended to locate the lateral limits of geothermal reservoirs, but such surveys provide very little information about the variation of resistivity with depth from the surface. Such information was obtained at a few locations using the Schlumberger sounding method, capable of mapping changes in resistivity at depths up to about 400 meters, and the electromagnetic sounding method, capable of detecting changes at depths ranging from 1 to 3 kilometers.

Schlumberger direct-current soundings were made using a technique which has long been taken as standard (see Keller and Frischknecht, 1967, for a detailed discussion of resistivity sounding). Resistivity measurements were made with an array of four electrode contacts, spaced along a straight line. Current was provided to the ground through the outermost pair of electrodes, while voltage was measured with the inner pair. The depth to which a boundary in resistivity can be detected is roughly half the separation between the current electrodes. In making a sounding, this separation is increased incrementally to provide successively greater depths of investigation. Spacings ranging from 3 meters to 450 meters (half the current electrode separation) were used for the soundings described in this report. A total of seven soundings was made in areas of special interest, as indicated from the results of the dipole mapping surveys.

The details of field techniques, data reduction procedures and the field data are included in appendices at the end of the report. The resistivity structures recognized at the Valles Caldera prospect are decribed in the section entitled "Summary of Results." Inferences regarding the probable existance of a geothermal reservoir capable of sustaining power production are drawn in the final section of the report. 
Dipole mapping surveys were carried out at the Valles Caldera prospect using seven dipole sources, located as shown on Figure 1 (the base map in Figure 1 is a reduced-scale copy of portions of the Jemez Springs and Frijoles 15-minute topographic quadrangles). Contour maps of the values for apparent resistivity are given on Plates $1,3,5,7$ and 9, accompanying this report, while contour maps of values for apparent conductance are given in Plates $2,4,6,8$ and 10 . It should be noted that several of these plates contain data from the dipole sources, and the contours for the two sets of data so presented are not continuous from one part of the map to the other.

Histograms showing the distributions of observed values of resistivity and conductance are given in two figures. The median value for somewhat more than 600 determinations of apparent resistivity is 31 ohmmeters, while the median value for conductance from the same group of measurements is 80 mhos. Considering the definition of apparent conductance, the average thickness of the surficial porous rocks in the prospect area is no greater than $2.4 \mathrm{~km}$ (the product of the median resistivity and the median conductance).

The results of dipole mapping are summarized in two maps showing the locations of regions with low resistivity and high conductivity. In this presentation, a low resistivity is taken to be a value of 200 mhos or more.

Considering all the data, it appears that the swath of ground with low resistivity paralleling Sulfur Creek has an average resistivity of 10 to $15 \mathrm{ohm}$-meters to a depth of 1400 meters on the average. The strong anomaly north of Horseshoe Springs probably represents rocks with a comparable thickness, but with a resistivity reduced to 3 to $4 \mathrm{ohm}-$ meters. This pattern of resistivity -- a sharply bounded region with resistivity of 3 to $10 \mathrm{ohm}$-meters -- is typical of geothermal systems in other parts of the world. The total conductance observed in the anomalous areas is considerably lower than that in most geothermal fieids. Typically, conductance reaches values of 1000 to 2000 mhos at places such as Wairaki. The low values in the Valles Caldera probably result from the combined effect of a relatively thin section of porous rock, and a porosity that is somewhat lower on the average than in most geothermal fields found in volcanic rocks. 


\section{TABLE OF CONTENTS OF THE REPORT}

TITLE

$\underline{\text { PAGE }}$

Abstract

Table of Contents

ii

Introduction

1

Summary of Results 3

$\begin{array}{lr}\text { Evaluation } & 20\end{array}$

$\begin{array}{ll}\text { References } & 109\end{array}$

Appendix I: Dipole Mapping Data 28

Appendix II: Electromagnetic Sounding Data $\quad 74$ 
REPORT NO. 24

EXECUTIVE SUMMARY

\title{
ADDITIONAL ELECTRICAL GEOPHYSICAL \\ SURVEYS IN THE VALLES CALDERA AREA, SANDOVAL COUNTY, NEW MEXICO
}

FROM A REPORT

\author{
Prepared For \\ UNION GEOTHERMAL DIVISION \\ UNION OIL COMPANY OF CALIFORNIA \\ LOS ANGELES, CALIFORNIA
}

\author{
Prepared By \\ GROUP SEVEN, INC. \\ GOLDEN, COLORADO \\ DECEMBER 1972
}

Summary Prepared By

WESTEC SERVICES, INC.

ALBUQUERQUE, NEW MEXICO

JUNE 1980 


\begin{abstract}
Group Seven, Inc., in this report, extended the resistivity surveys originally carried out in the Valles Caldera area of Sandoval County, New Mexico, by using one additional source to make both dipole mapping measurements and electromagnetic soundings. These measurements were concentrated along a profile extending up Redondo Creek and into the headwaters of Jaramillo Creek. The patterns of high and low resistivity seen with this survey do not differ essentially from those seen earlier. This report is an extension of a previous report with a similar title. Most of the volume of the report is a compilation of data gathered.
\end{abstract}


Group Seven, Inc. carried out additional electrical resistivity surveys in the Valles Caldera area of north-central New Mexico to further detail an area studied earlier during May and June 1972. The earlier study was documented in Report No. 23. Both studies were carried out on behalf of the Union Oil Company of California. Field operations for this report covered the first two weeks of October 1973.

The Valles Caldera prospect occupies an area some 12 miles square in Sandoval County, New Mexico, west of the city of Los Alamos. The area in which the present survey was carried out lies within the limits of four U.S. Geological Survey 7.5 minute topographic quadrangle maps; these are the Bland, Valle Toledo, Redondo Peak and Valle San Antonio quadrangles. The results of the current surveys are presented on a basemap at a scale of 1:24000 prepared from these quadrangle maps. Results of the earlier surveys were presented on base maps at the same scale prepared from the 1:62500 scale quadrangles of the same area, the Jemez Springs and Frijoles quadrangles.

The resistivity surveys carried out by Group Seven, Inc., during May and June of 1972 delineated an area of moderately low resistivity generally west of Sulfur Creek, along the western edge of the prospect. The survey indicated only very limited areas of moderate resistivity along Redondo Creek, where both early and recent drilling has produced geothermal fluids. The additional electrical surveys described in this report were carried out to clarify the possible association of the producing wells with a geothermal reservoir.

For the surveys described in this report, a single dipole source was used, located in Valle Grande, near the Ranch headquarters. Most of the measurements, both dipole mapping and electromagnetic sounding, were made along a traverse extending up Redondo Creek and into the headwaters of Jaramillo Creek. Some measurements were also made to the north and west of this traverse, and three electromagnetic soundings were made to the southeast of the source, along the edge of Valle Grande.

\subsection{SUMMARY AND CONCLUSIONS}

Both the dipole mapping data and the electromagnetic sounding data from the single source substantiate earlier conclusions regarding the small size of the anomalously conductive area in Redondo Creek Valley. Generally, the conductive surface rocks along Redondo Creek were found to be less than one kilometer thick, and to have a moderateiy high resistivity, 40 to 60 ohm-meters. The anomalous area at the head of Redondo Creek was found to have an area of less than one square mile, if the 100 ohm contour is considered to be its boundary. Because of this limited area, it is difficult to obtain reliable depth estimates 
with any of the electrical surveying techniques. However, the electromagnetic sounding data and the dipole mapping data both indicate that the 100 mho conductance contour is associated with an area in which the surface resistivity is $20 \mathrm{ohm}-$ meters or less. The corresponding depth to resistant rock is, therefore, of the order of 2 kilometers or less.

The source data show clearly two boundaries marking off areas with distinctively different electrical properties. One is an east-west boundary along Jaramillo Creek, south of which the resistivity is quite high. The area along Redondo Creek does not belong to this category, and a boundary must exist to the east of Redondo Creek outside the area where measurements were made. The other major boundary trends northwest-southeast, at the southwest end of Redondo Creek, and bounds an area of high conductance to the southwest. 
SAMPLES OF DATA SHEETS

24.5 


\section{Appendix $\mathbf{I}$.}

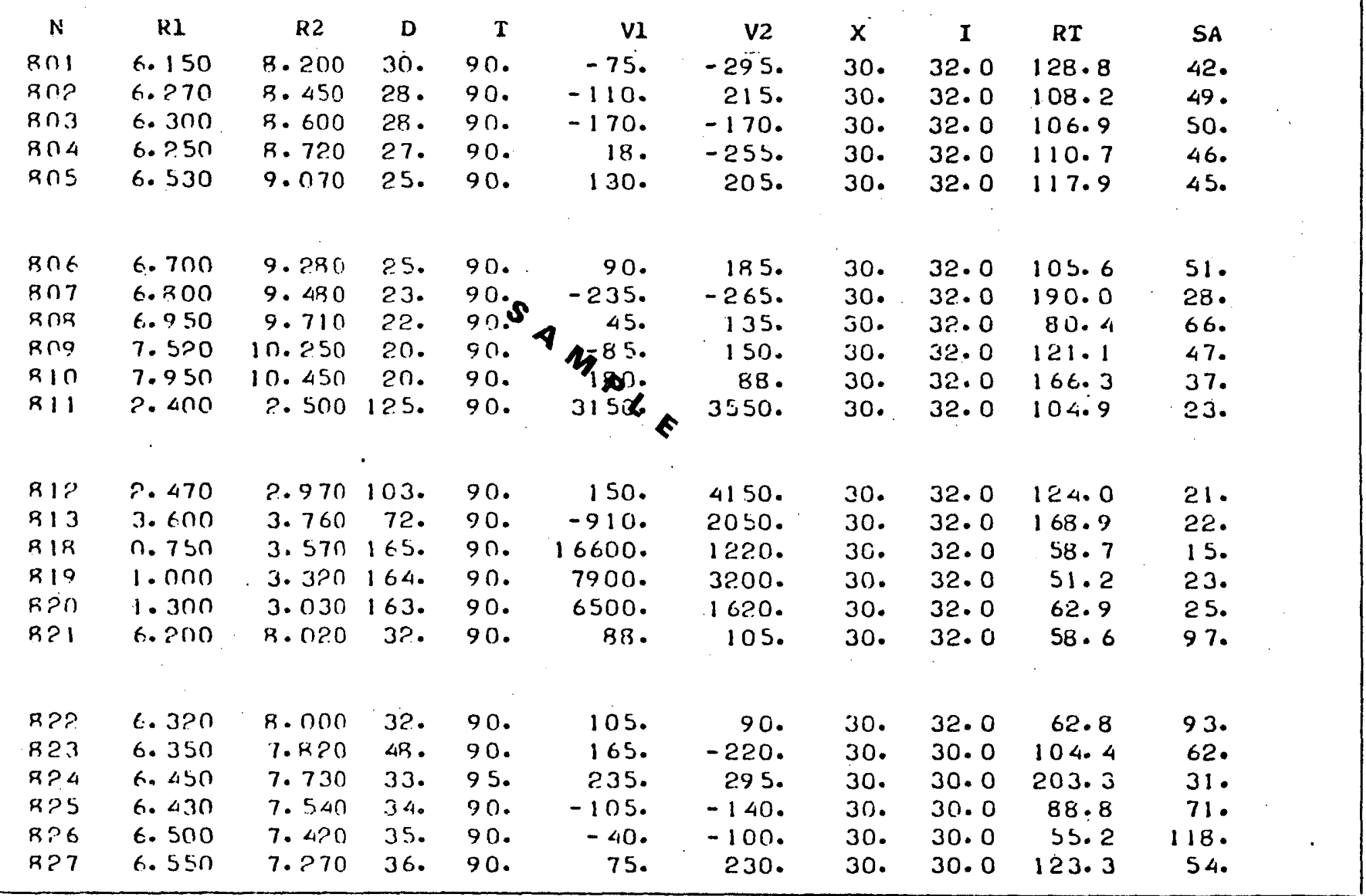


VALLES EM SOUNDING 801

OFFSET DISTANCE IS 6850. METERS

LOOP AREA IS 1664 SQUARE KILOMETERS

S月 URCE LENGTH IS 4290 . METEFS

CURPENT IS 32.0 AMPERES

DEFLECTION ANGE IS 24. ODEGREES

DIGI TIZING SCALE IS 0. 229MI CRO WOL TS/DIV

\section{EDITED AND STACKED DATA}

\begin{tabular}{|c|c|c|c|c|}
\hline TIME & NUMRE & A VER.AGE & ST. DE $V_{\bullet}$ & EARLY $R$ \\
\hline .02 & 5 & $0.145 E-03$ & $0.164 \mathrm{E}-04$ & $0.324 E+02$ \\
\hline .04 & 5 & $0.203 E-03$ & $0.341 E-05$ & $0.454 E+02$ \\
\hline .06 & 5 & $0.216 E-03$ & $0.9295-05$ & $0.482 E+02$ \\
\hline .08 & 5 & $0.204 E-03$ & $0.833 E-05$ & $0.456 E+02$ \\
\hline .10 & 5 & $0.170 E-03$ & $0.162 E-04$ & $0.381 E+02$ \\
\hline .12 & 5 & $0.145 E-03$ & C. $1960 E-04$ & $0.325 E+02$ \\
\hline .14 & 5 & $0.123 E-03$ & $0.214 E-04$ & $0.27 \in E+02$ \\
\hline .16 & 5 & $0.108 E-03$ & $0.234 E-04$ & $0.242 E+02$ \\
\hline - 18 & 5 & $0.977 E-04$ & $0.230 E-04$ & $0.218 E+02$. \\
\hline$\cdot 20$ & 5 & $0.734 E-04$ & $0.137 E-04$ & $0.164 E+02$ \\
\hline$\cdot 22$ & 5 & $0.550 E-04$ & $E-04$ & $0.123 E+02$ \\
\hline .24 & 5 & $0.427 E-04$ & $0.189 E-04$ & $0.954 E+01$ \\
\hline$\cdot 26$ & 5 & $0.390 E-04$ & $0.201 E-04$ & $0.872 E+01$ \\
\hline - 28 & 5 & $0.372 E-64$ & $0.211 E-04$ & $0.831 E+01$ \\
\hline . 30 & 5 & $0.344 E_{-} 0^{2}$ & $0.153 E-04$ & $0.769 E+01$ \\
\hline - 32 & 5 & $0.317 E^{504}$ & $0.119 \mathrm{E}-04$ & $0.708 E+01$ \\
\hline - 34 & 5 & $0.289 E-04$ & $0.150 E-04$ & $0.645 E+01$ \\
\hline .36 & 5 & $0.261 E-04$ & $0.154 E-04$ & $0.585 E+01$ \\
\hline - 38 & 5 & $0.243 E-\cap 4$ & $0.123 E-04$ & $0.544 E+01$ \\
\hline .40 & 5 & $0.133 E-04$ & $0.967 E-05$ & $0.297 E+01$ \\
\hline - 42 & 5 & $0.780 E-05$ & $0.109 E-04$ & $0.174 E+01$ \\
\hline .44 & 5 & $0.596 E-05$ & $0: 143 E-04$ & $0.133 E+01$ \\
\hline .46 & 5 & $0.32 .1 E-05$ & $0.133 E-04$ & $0.718 E+00$ \\
\hline-43 & 5 & $0.826 E-05$ & n. $133 E-04$ & $0.185 E+01$ \\
\hline . $5 n$ & 5 & $0.123 E-04$ & $0.152 E-04$ & $0.257 E+01$ \\
\hline . 52 & 5 & $0.101 E-04$ & $0.195 \mathrm{E}-04$ & $0.226 E+01$ \\
\hline .54 & 5 & $0.2 .75 E-05$ & $0.141 E-04$ & $0.615 E+00$ \\
\hline .56 & 5 . & $0.367 \varepsilon-05$ & $0.133 E-04$ & $0.821 E+00$ \\
\hline - 58 & 5 & $-0.917 E-06$ & $0.140 E-04$ & $-0.205 E+00$ \\
\hline - 60 & 5 & $0.917 E-06$ & $0.127 \mathrm{E}-04$ & $0.205 E+00$ \\
\hline .62 & 5 & $-0.183 E-05$ & $0.9225-05$ & $-0.410 E+00$ \\
\hline .64 & 5 & $-0.132 E-05$ & $0.117 E-0 \Delta$ & $-0.303 E+00$ \\
\hline .66 & 5 & $-0.133 E-05$ & $0.171 E-04$ & $-0.410 E+00$ \\
\hline$\cdot 68$ & 5 & $0.550 E-05$ & $0.191 E-04$ & $0.123 E+01$ \\
\hline$\cdot 70$ & 5 & $0.229 E-05$ & $0.135 E-n \angle$ & $0.513 E+00$ \\
\hline$\cdot 7 ?$ & 5 & $-0.133 E-05$ & $0: 105 E-04$ & $-0.305 E+00$ \\
\hline .74 & 5 & $-0.734 E-05$ & $0.11<E-04$ & $-0.164 E+01$ \\
\hline .76 & 5 & $-0.101 E-04$ & $0.1012-04$ & $-0.226 E+01$ \\
\hline$\cdot 78$ & 5 & $-0.826 E-05$ & $0.924 E-05$ & $-0.185 E+01$ \\
\hline
\end{tabular}

GROUP SEVEN 


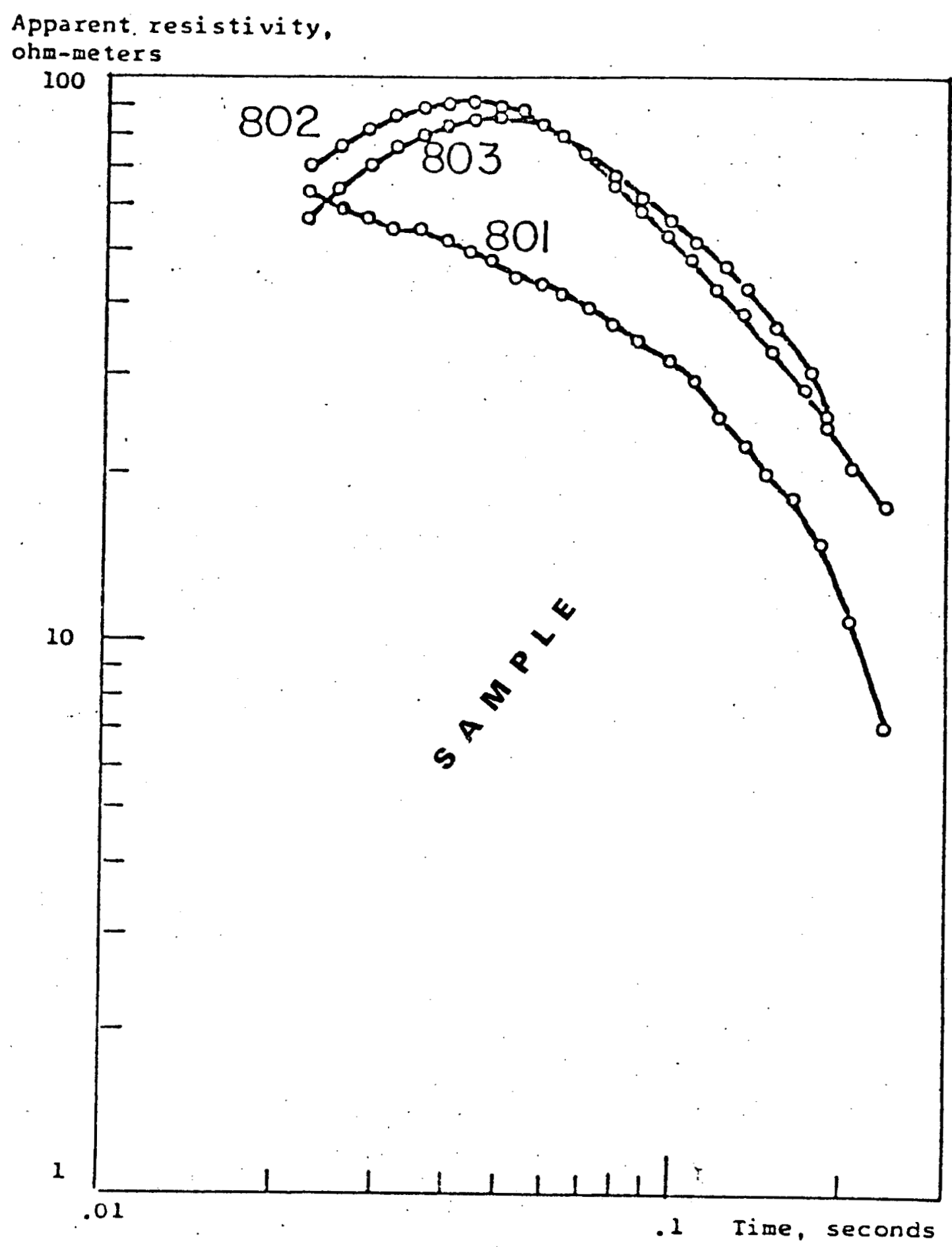

GROUP SEVEN 
REPORT NO. 25

EXECUTIVE SUMMARY

REPORT ON THE

RECONNAISSANCE RESISTIVITY SURVEY

OF THE

BACA PROPERTY,

VALLES CALDERA AREA

SANDOVAL COUNTY, NEW MEXICO

FROM A REPORT

\author{
Prepared For \\ Prepared By \\ UNION GEOTHERMAL DIVISION \\ McPHAR GEOPHYSICS \\ UNION OIL COMPANY OF CALIFORNIA \\ SEPTEMBER 1973 \\ LOS ANGELES, CALIFORNIA
}

Summary Prepared By

WESTEC SER VICES, INC.

ALBUQUERQUE, NEW MEXICO

JUNE 1980 


\begin{abstract}
The purpose of this Reconnaissance Survey was to locate and delineate lowresistivity zones that might indicate areas of concentrated thermal activity. Measurements were made with 2000 foot dipoles at one-through-four dipole separations along widely-spaced reconnaissance lines through most of the valley in the area for easier accessibility. The resistivity survey results are shown on data plots. Also enclosed with this report is a plan map of the survey area showing the location of the six survey lines. Anomalous responses which may represent increased geothermal activity have been located on five of the six survey lines. A discussion of the resistivity results along each survey line is given.
\end{abstract}


McPhar Geophysics has completed a Reconnaissance Resistivity Survey on the Baca Property, Valles Caldera Area, Sandoval County, New Mexico. The reader is referred to Reports No. 23 and 24 for related studies. The geology of the Valles Caldera is described in an Outline of the Geology of the Jemez Mountains, New Mexico, by C.S. Ross, et al., New Mexico Geological Society, Twelfth Field Conference, pgs. 139143. Generally, the geology consists of a thick volcanic pile varying from basalt to rhyolite which represents successive effusions during the Pliocene. Post-caldera rhyolite forms most of the hills in the survey area and solfataric and hot-spring activity are present within the area. The Valles Caldera had been designated as a KGRA prior to this study.

The purpose of the Reconnaissance Survey was to locate and delineate low-resistivity zones that might indicate areas of concentrated thermal activity. Measurements were made with 2000 foot dipoles at onethrough-four dipole separations along widely-spaced reconnaissance lines through most of the valley in the area for easier accessibility. A frequency of $0.125 \mathrm{~Hz}$ was used in order to minimize attenuation of the electric field due to eddy current dissipation of energy and at the same time, avoid telluric noise.

\subsection{SUMMARY AND CONCLUSIONS}

The resistivity survey results are shown on data plots. Also enclosed with this report is a plan map of the survey area showing the location of the survey lines at a scale of $1^{\prime \prime}=2000^{\circ}$. The definite, probable and possible resistivity low anomalies are indicated on the plan map as well as on the data plots. The representations on the map and plots are the surface projections of the anomalous zones as interpreted from the location of the transmitter and receiver electrodes when the anomalous values were measured.

The variation of the resistivity response of the reconnaissance survey is indicative of the complex geology of the Valles Caldera area. Anomalous responses which may represent increased geothermal activity have been located on five of the six survey lines. A discussion of the resistivity results along each survey line is given in the text of the report.

The reconnaissance resistivity survey of the Valles Caldera area has outlined some areas of high conductivity which may represent increased geothermal activity. One survey line of this survey exhibits lowresistivity values for its entire length and may represent a possible fault zone which is a conduit for geothermal fluids. Another line crosses this proposed fault zone and suggests that the possible lateral extent of this zone is approximately 4000 feet. 
The definite anomalies on the south end of one of the survey lines and the north-west end of another line are also of interest. Refer to the report for actual locations and orientations.

The survey line across Valle Grande failed to locate any anomalous zones.

A complete correlation of all geological, geochemical, geophysical and well data was recommended prior to the selection of drill-hole locations. 
REPORT NO. 26

EXECUTIVE SUMMARY

SUPPLEMENTAL REPORT ON THE

RECONNAISSANCE RESISTIVITY AND

SCHLUMBERGER DEPTH SOUNDING SURVEYS

OF THE BACA PROPERTY

VALLES CALDERA AREA

SANDOVAL COUNTY, NEW MEXICO

FROM A REPORT

\author{
Prepared For \\ Prepared By \\ UNION GEOTHERMAL DIVISION \\ MCPHAR GEOPHYSICS \\ UNION OIL COMPANY OF CALIFORNIA \\ JANUARY 1974 \\ LOS ANGELES, CALIFORNIA
}

Summary Prepared By

WESTEC SER VICES, INC.

ALBUQUERQUE, NEW MEXICO

JUNE 1980 


\begin{abstract}
This report should be considered an appendix to the previous, related report entitled "Report on the Reconnaissance Resistivity Survey of the Baca Property, Valles Caldera Area, Sandoval County, New Mexico," McPhar, 1973. Included in this report are notes on geothermal exploration using the resistivity method and a supplem ental report of a similar title to the aforementioned survey. The notes on the resistivity method of exploration included detail as to how and why the measurements are made and how the results are interpreted. The supplemental report is actually a continuation of the original study. Where the first study completed six survey lines, the supplement completed two more, plus it includes five depth sounding surveys by Schlumberger.
\end{abstract}


McPhar Geophysics, Inc., has continued and completed reconnaissance resistivity and five Schlumberger depth sounding surveys in Valles Caldera Area, Sandoval County, New Mexico. The initial survey was terminated in July 1973 by mutual agreement of Union Oil and McPhar. Termination was caused by excessive telluric noise resulting from intense thunderstorm activity in the area. The survey was resumed and completed following the end of the active thunderstorm period. For related information refer to Reports No. 23 through 25 .

The purpose of the reconnaissance survey was to locate and delineate zones of low resistivity that might indicate areas of concentrated thermal activity. The Schlumberger depth sounding surveys were made to provide additional information on the thickness and resistivity of the geoelectric column in selected anomalous zones defined by the previous survey. In both cases, a frequency of $0.125 \mathrm{~Hz}$ was used in order to minimize attenuation of the electric field due to eddy current dissipation of energy and at the same time, avoid telluric noise. The reconnaissance survey was made with 2000 foot dipoles along two reconnaissance lines. The Schlumberger depth soundings were made with the expanding Schlumberger electrode array with spacings expanding from 500 feet to as much as 15,000 feet where required by survey specifications.

\section{$2.0 \quad$ SUMMARY AND CONCLUSIONS}

No summary and conclusions are appropriate for the notes on resistivity measurements. The reader is referred to the text of the report.

The resistivity survey results are shown on plots in the manner described in the notes which accompany this report. The definite, probable and possible resistivity low anomalies are indicated on a plan map as well as on data plots. The representations indicate the surface projection of the anomalous zones as interpreted from the location of the transmitter and receiver electrodes when the anomalous values were measured.

The thickness and resistivity of the varicus layers are illustrated graphically on each depth sounding curve and are tabulated. The geoelectric section has been derived by standard curve matching techniques.

Anomalous resistivity responses are present on each survey line. The complex resistivities present on the first six surveys of the original report do not occur in two surveys oi this report. A discussion of the results of each survey line is given.

The geoelectric section was derived from the depth sounding data by curve-matching techniques using a set of curves calculated for a layered earth. As illustrated on the dipole-dipole resistivity profile, the 
area surveyed with the depth sounding technique is not layered but complex, with vertical and horizontal discontinuities. Therefore, the geoelectric section is an estimate that ignores all vertical discontinuities, and errors of unknown magnitude are always present. A discussion of each depth sounding line is given.

The reconnaissance resistivity survey has further delineated an area of interest indicated by two of the survey lines of the previous survey. A definite anomaly was located. As suggested by Bell in Report No. 25, the anomalous zone defined by three survey lines appears to be a northwest-trending fault zone. The fault zone may serve as the plumbing system for ascending geothermal fluids.

A definite anomaly at 20 East to 20 West, open to the west, is also of interest. This open anomaly may be the northern extension of a zone indicated on two survey lines. Additional lines are necessary to fully delineate and define this possible zone.

The Schlumberger depth soundings indicate excellent shallow conductivity on two of the sounding lines further establishing this zone as a potential thermal area.

Comparison between the geoelectric section derived from the depth soundings with the dipole-dipole data at each point shows poor to good correlation. The lack of correlation in each instance is immediately apparent when the geologic complexity of the region surveyed is considered. Schlumberger depth soundings are designed to delineate the geoelectric section in a layered earth. As illustrated on the dipoledipole profiles, the Valles Caldera is definitely not a layered earth situation. 
REPORT NO. 27

EXECUTIVE SUMMARY

\title{
QUANTITATIVE GRAVITY INTERPRETATION \\ VALLES CALDERA, NEW MEXICO
}

\section{FROM A REPORT}

Prepared By

\author{
R.L. Segar \\ UNION GEOTHERMAL DIVISION \\ UNION OIL COMPANY OF CALIFORNIA \\ LOS ANGELES, CALIFORNIA
}

Summary Prepared By

WESTEC SERVICES, INC.

ALBUQUERQUE, NEW MEXICO

JUNE 1980 


\begin{abstract}
A gravity survey of the Baca Ranch which comprises the Valles Caldera, New Mexico, was run by Union Oil Company personnel in October and November 1973. The purpose of the survey was to better define the structural configuration of the caldera floor that resulted from events that occurred in the Pleistocene era. The report details the findings of the survey and includes eight maps which display the findings and successive interpretations of the study. This study augments previous geological data and may have been updated by more recent geological and geophysical studies and data.
\end{abstract}


From surface geology, it is known that the Valles Caldera is a relatively negative gravity area, filled with various types of rock materials that are all less dense than a normal granite or limestone $(2.7 \mathrm{~g} / \mathrm{cc})$. Theoretically, this situation would produce a large negative gravity anomaly coincident with the collapsed area. This certainly is the case as shown by the USGS reconnaissance gravity work. After establishing that the gravity in a broad sense agrees with the surface geology and is not influenced to a great extent by other extraneous sources, it is then only necessary to understand the density contrast and its variation with depth in order to give a good structural picture of the collapsed area.

Since there were no suitable density analyses or logs for this area, one must make approximations of the density variations from past experience or data from similar areas. In spite of the lack of density information and that it would be a limiting factor in the accuracy of interpretation, it was decided to proceed with the survey. The goal was to map the ring fault system and obtain some estimate of the shape and depth of the deeper rocks (Paleozoic and Pre-Cambrian).

In this geophysical investigation, the primary concern was discerning the present structural configuration of the caldera floor that resulted from events that took place in Pleistocene times.

\subsection{SUMMARY AND CONCLUSIONS}

Three distinct trends are noted. The first is in the Sulphur Creek and Redondo Creek area. This negative is probably due to the caldera fill in the area causing a higher density contrast than $0.35 \mathrm{~g} / \mathrm{cc}$. The second is the Redondo Creek, Recondo Peak and Jaramillo Creek area where a large positive residual is present. The positive corresponds to the approximate outcrop pattern of the Bandelier Tuff which could mean that the anomaly could have been generated by an incorrect Bouguer correction. In this case it would be an underestimate for the tuff $(2.45 \mathrm{~g} / \mathrm{cc})$. It could also be caused by too deep a Paleozoic surface. The other negative trend along the east edge of the caldera is probably caused by the presence of substantial amounts of lake beds or caldera fill. This negative means that there is a larger density contrast than $0.35 \mathrm{~g} / \mathrm{ce}$.

This investigation has shown that the large negative gravity anomaly is caused primarily by a collapsed volcano. It has also shown that there is an apparent density contrast of $0.35 \mathrm{~g} / \mathrm{cc}$ and that a Top Paleozoic map structure could be generated by computer processing at Research Center. This work indicated that there is as much as 15,000 feet of lighter density material within the caldera. Also this map has shown that the ring dike system is not always coincident with the ring fracture system, and that the ring fracture is located at a considerable distance inward 
from the topographic rim. The concept of "resurgent" doming was neither enhanced or disproved, how ever, the gravity does indicate that the effect of resurgent doming is much more localized than that envisioned by Smith and Bailey (1968).

It is recommended that this interpretation be combined with the geological and geophysical data to form a more complete understanding of the physical nature of this caldera. A specific recommendation on areas of exploration interest within the caldera cannot be made at this time. This should be done by persons with more knowledge of the electrical and thermal properties of the near-surface rocks. 
REPORT NO. 28

EXECUTIVE SUMMARY

MERCURY SOIL GAS SURVEY

BACA PROSPECT

SANDOVAL COUNTY, NEW MEXICO

FROM A REPORT

Prepared For

UNION GEOTHERMAL DIVISION

UNION OIL COMPANY OF CALIFORNIA

LOS ANGELES, CALIFORNIA
Prepared By

APPLIED GEOPHYSICS, INC.

SALT LAKE CITY, UTAH

AUGUST 1974

Summary Prepared By

WESTEC SERVICES, INC.

ALBUQUERQUE, NEW MEXICO

JUNE 1980 


\section{ABSTRACT}

This study was conducted by Union Oil Company as a brief analysis of the usefulness of the mercury soil gas method of detecting or analyzing a geothermal anomaly. The sample area was approximately one-half mile of road in the Valles Caldera in north-central New Mexico. The reasons and procedures for conducting a mercury soil gas survey are given. This study may be of use as background information on the geothermal reservoir although it was not intended to be. 


\section{$1.0 \quad$ INTRODUCTION AND SCOPE}

Mercury is the only metal that exists as a liquid at ordinary temperatures. As such, it is a highly mobile element having sufficient vapor pressure to cause it to move great distances, even when confined by low permeability barriers such as exist in the subsurface of the earth. When activated by high temperatures, however, its capability to migrate is increased many fold.

The Hg soil gas method for prospecting for geothermal cells is thus based on three premises: 1) the ability of heat to mobilize mercury in pre-existing subsurface rocks, and 2) the contribution of juvenile mercury accompanying juvenile hydrothermal fluids, and 3) the lower pressure existing at the surface of the earth which causes the mercury to move toward that surface. The mercury soil gas method should, therefore, be an ideal prospecting tool for outlining potential areas of geothermal energy.

The mercury soil gas grid was carried out along the existing road network as specified by the Union Oil Geothermal Division. The sample interval was one-half mile along roads in the caldera.

2.0 SUMMARY AND CONCLUSIONS

A more uniform two-dimensional sampling net, with scattered sampling points between roads, would have provided a better picture of the distribution of mercury soil gas in the area, but was not judged necessary for this preliminary test. The assay values are given in parts per billion and appear above each sample point in a graphical representation of the data. Above the assay value appears the weighted average calculated according to the formula: $A v=(a+2 b+c) / 4$, where $b$ is the sample value being averaged and $a$ and $c$ are the assay values on either side.

An even dozen anomalies were encountered by this survey, an anomaly in this case being defined as an area having samples with averages greater than $100 \mathrm{ppb}$. Only two of these show averages exceeding $200 \mathrm{ppb}$, and these occur around the two high assays at two points. In both of these areas adjacent samples support the high assays of the central points.

The background level in the area may be judged by references to a graph of the data, where the "most frequent value" appears to be approximately $62 \mathrm{ppb} \mathrm{Hg}$. If the area as a whole is elevated in mercury content because of the pronounced geothermal activity, then this average value may be likewise elevated, and the true background value may be somewhat lower, perhaps $50 \mathrm{ppb}$. The above mentioned anomalous areas can, therefore, be consicered as having $\mathrm{Hg}$ soil gas levels at least twice background. 
Since no geological or geothermal parameters were provided for comparison with the $\mathrm{Hg}$ soil gas results, it is not possible in this report to evaluate the effectiveness of the $\mathrm{Hg}$ soil gas technique as a prospecting tool on the Baca prospect. 
SECTION

PAGE

I.

INTRODUCTION

II.

PROCEDURE

III.

RESULTS - BACA PROSPECT

IV.

CONCLUSIONS AND RECOMMENDATIONS

\section{ILLUSTRATIONS}

$\underline{\text { LOCATION }}$

Figure 1

Histogram of $\mathrm{Hg}$ Soil Gas Values

Page 5

Plate I

Plan Map Showing Hg Soil Gas Values and Sample Locations

In Pocket 
REPORT NO. 29

EXECUTIVE SUMMARY

MERCURY ANALYSIS - 1974 GRADIENT HOLES

FROM A REPORT

\author{
Prepared For \\ UNION GEOTHERMAL DIVISION \\ UNION OIL COMPANY OF CALIFORNIA \\ LOS ANGELES, CALIFORNIA
}

\author{
Prepared By \\ ROCKY MOUNTAIN \\ GEOCHEMICAL CORP. \\ MIDVALE, UTAH \\ DECEMBER 1974
}

Summary Prepared By

WESTEC SER VICES, INC.

ALBUQUERQUE, NEW MEXICO

JUNE 1980 


\begin{abstract}
This report is a tabulation of mercury analyses from 47 samples. It consists of two pages: a cover letter and a data sheet. The samples were taken from two to three levels in 16 gradient holes at the Valles Caldera geothermal reservoir in north-central New Mexico. The samples were taken from the 100, 200, and 250 foot levels in the holes, except where the holes were not deep enough. The data sheet has hand-written notes on which wells indicate an anomaly on the basis of mercury concentration. No text or relative locations for the wells are given. The data may be useful as background for related studies.
\end{abstract}


THE DATA SHEET

29.3 
UNION OIL CO. OF CA Date $12 / 31 / 74$ RMGC Job No $74-47-32$ ST -

Samplean the gremen antiryo

Sample No.

51- TH

$51-200^{\circ}$

$51-250^{\prime}$

$52-100^{\prime}$

$52-2.00^{\prime}$

$52-250^{\prime}$

$53-100^{\prime}$

53-200'

$53-250^{\prime}$

$54-100^{\circ}$

54-200!

$54-250^{\prime}$

55-10n'

$55-290^{\circ}$

55-250'

$56-100^{\prime}$

$56-140^{\circ}$

57-100'

57-200'

$57-250^{\circ}$

$58-100^{\circ}$

$52-200^{\prime}$

$58-250^{\prime}$

$50-100^{\prime}$

$59-200^{1}$ ppo of 1974 Gramliantholes

Page

of 2

Sample No.

$59-250^{\circ}$

$\mathrm{ppb}$

Mercury

$620)(A N$

$6 n-10 n !$

$6 n-200^{\prime}$

$60-250^{\prime}$

620) Def

518

$460)$ Det $A$

61-1n0'

61-200'

$61-25 n^{\prime}$

$\left.\begin{array}{c}80 \\ 190 \\ 135\end{array}\right)$ Pubs

430
$730 \%$

$55]+B^{2}+10 \mathrm{~A}$

52-100'

$62-200^{\prime}$

$62-25 n^{\prime}$

$63-170$

63-2nn'

$63-25 n^{\prime}$

$\left.\begin{array}{c}80 \\ 55 \\ 55\end{array}\right) N U$

$\left.\begin{array}{l}25 \\ 55 \\ 80\end{array}\right] \cup 0$

$\left.\begin{array}{l}55 \\ 25 \\ 55\end{array}\right) \mathrm{NO}$

$64-100^{\prime}$

54-200'

54-25n'

65-1nn'

65-20n'

$65-25 n^{\prime}$

$\left.\begin{array}{l}25 \\ 8 n \\ 8 n\end{array}\right) N O$

755

$\left.\begin{array}{l}237 r \\ 190 \\ 110\end{array}\right\} D p+f_{0}$

945

66-100'

$\left.\begin{array}{l}25 \\ 25 \\ 55\end{array}\right) N$

ล6-2nก'

$\left.\begin{array}{l}55^{\circ} \\ 210\end{array}\right\} N$

$66-25 n^{\prime}$

1030

945 Def

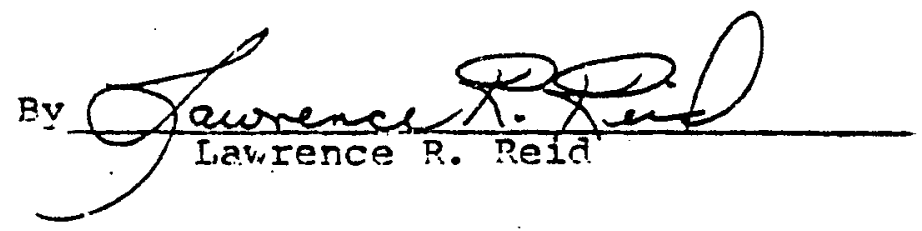

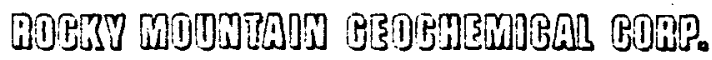

29.4 
REPORT NO. 30

EXECUTIVE SUMMARY

\title{
GEOTHERMAL GEOLOGY OF THE REDONDO CREEK AREA \\ BACA LOCATION, NEW MEXICO
}

FROM A REPORT

\author{
Prepared By \\ T.R. Slodowski \\ UNION GEOTHERMAL DIVISION \\ UNION OIL COMPANY OF CALIFORNIA \\ LOS ANGELES, CALIFORNIA \\ APRIL 1976
}

Summary Prepared By

WESTEC SER VICES, INC.

ALBUQUERQUE, NEW MEXICO

JUNE 1980 


\begin{abstract}
This report is a brief four-page summary of all Valles Caldera geological and geophysical data that was available in early 1976, although no references are cited. It proceeds beyond the summary to analyze the causes of success or failure of obtaining a productive well. Further, the report recommends potential areas to explore with drilling maps which display the area geology, structure sections, isotherms, and an isopach.
\end{abstract}


The two main prerequisites for success in developing a geothermal field as adopted by Union Oil Company are: sufficiently high temperatures and permeable reservoir rocks. Success in the Baca project, to the date of this report, has been marginal because of the lack of sufficient primary interstitial porosity and permeability and the necessity to encounter fracture porosity and permeability. This report analyzes the parameters of temperature, geologic structure, reservoir lithology, and past drilling experience to reach recommendations on future drilling.

\subsection{SUMMARY AND CONCLUSIONS}

Temperature has been a problem in only one well, Baca 5, which has a large temperature reversal. Reference to Figures 4-6 (400F and 500F isothermal maps) shows the isothermal surfaces to dip steeply toward and roughly parallel the northwest slope of Redondo Peak. This is probably caused by most of the large amount of rainfall and snow melt on this slope infiltrating deeply into the subsurface via large vertical faults, inst ead of being carried off in surface streams.

As the maps show, the highest temperatures are encountered along Redondo Border with a lobe extending east and southeast of Baca Wells No. 11 and 15 .

The structure map on the base of the Bandelier Tuff and the structure section through the wells on the west side of Redondo Creek suggest that the high temperature area may be controlled by both stratigraphy and structure. The Baca 10, 6, 15, and 11 wells encountered Tertiary sands beneath the Paliza Canyon andesite. These sands have sufficient porosities and permeabilities to serve as aquifers and permit deeper hot water to the west to convect up-dip towards Redondo Border. Fairly closely spaced cross-faulting and associated fractures in the area of the above mentioned wells could also allow convection of hotter, deeper waters in this area. The structurally high areas, although somewhat complicated by faulting, coincide rather well with the isothermal surface highs. The structural high is readily apparent on the structure section where Baca 15 is on the highest part of the structural high.

The greater majority of producing zones thus far encountered in wells in the Redondo Creek area have been in the Bandelier Tuff. The Paliza Canyon andesite appears to contain tuffs or open fractures, locally, which are capable of producing fluid. However, generally the andesite is very highly altered to clays and most fractures may be closed. The Tertiary sands which occur beneath the andesite are probably the zones most capable of producing fluids, but their extremely fine grain size and unconsolidated character cause the sand to flow with the fluids. 
The success or failure of wells, then, is almost entirely dependent upon encountering open fractures in the Bandelier Tuff. Fractures are obviously most abundant at the intersection of two faults and, for a better future success ratio, wells must be located at fault intersections and not merely at locations which are easier to build (at the expense of the well).

Three of the figures show that the area approximately outlined by Baca $6,4,13$, and 16 contains the highest temperatures encountered. It is expected that most of Redondo Border and its northwest flank may have similar temperatures and future exploratory wells should be located west and northwest of Baca 11, 15, and 16. The isopach map shows this area to have 2000 feet to 4000 feet of Bandelier tuff below the $400 \mathrm{~F}$ isotherm. 


\section{FIGURE}

\section{1}

Geologic Map

2 Structure Section B-12 to B-16

3 Structure Section B-12 to B-13

$4 \quad 400 \mathrm{~F}$ Isotherm Map

$5 \quad 450 \mathrm{~F}$ Isotherm Map

$6 \quad 500 \mathrm{~F}$ Isotherm Map

7 Structure Map - Base Bandelier Tuff

8 Isopach Map - 400F to Base/Bandelier 
REPORT NO. 31

EXECUTIVE SUMMARY

\section{A MAGNETOTELLURIC - TELLURIC PROFILE SURVEY \\ OF THE VALLES CALDERA PROSPECT \\ SANDOVAL COUNTY, NEW MEXICO}

FROM A REPORT

Prepared For

UNION GEOTHERMAL DIVISION

UNION OIL COMPANY OF CALIFORNIA

LOS ANGELES, CALIFORNIA
Prepared By

GEONOMICS, INC.

BERKELEY, CALIFORNIA

DECEMBER 1976

Summary Prepared By

WESTEC SERVICES, INC.

ALBUQUERQUE, NEW MEXICO

JUNE 1980 


\section{ABSTRACT}

This report describes the results of a combined magnetotelluric (MT) telluric profile (TP) survey performed by Geonomies, Inc. of Berkeley for the Union Oil Company of California. The survey took place at the Baca Location in Sandoval County, New Mexico, during June and July 1976. Its purpose was to determine the thickness and structure of the volcanic sediments and underlying formations, and to interpret the results in terms of local geothermal potential. 
This report describes the results of a combined magnetotelluric (MT) telluric profile (TP) survey performed by Genomies, Inc. of Berkeley for the Union Oil Company of California. The survey took place at the Baca Location in Sandoval County, New Mexico, during June and July 1976. Its purpose was to determine the thickness and structure of the volcanic sediments and underlying formations, and to interpret the results in terms of local geothermal potential.

Telluric profile data were recorded using Geonomics' Mark II telluric receiver and a Brush 2-channel chart recorder. Stations were spaced 1000 feet apart on seven surveys and 500 feet apart on the last survey; locations are shown on a map included in the report.

Magnetotelluric (MT) data were recorded on the Geonomics Mark II system which utilizes a cryogenic magnetometer and a 4-channel FM tape recorder. Results were computer-processed. Layered resistivity models were obtained from MT data by matching input data to 2 and 3-layer model curves. These curves must be viewed as merely an aid in defining the local resistivity structure. Since the area does not even grossly approximate horizontal layering, the curves are given as a best fit set for each station. Several MT profiles were also drawn from raw apparent resistivity data. These offer the advantage of a direct qualitative interpretation of data that has not been subjected to the prejudices of the interpreter.

The recordings and the daily reports of the Space Environment Services Center, Department of Commerce, show the geomagnetic field during June and July was quiet to unsettled. Although such conditions provide fair to good signal for MT and TP surveying, the daily lightning storms in this part of New Mexico interfered considerably with data acquisition in the early afternoon when natural signals are strongest.

\section{$2.0 \quad$ SUMMARY AND CONCLUSIONS}

The complex sequence of volcanic rocks beneath the survey area and the multiple fracture patterns have a profound effect on the electric currents measured by the telluric profile and magnetotelluric methods. These effects can be enumerated as follows:

1. Elongate conductive fracture zones tend to channel telluric currents and polarize the incoming electric field signal. These features can yield misleading MT results.

2. There is significant evidence that such features cause incoherency and phase shifting of incoming signal. This effect is her ein called telluric "noise" for convenience. This is not meant to imply that geologic features generate noise; rather, the features affect incoming signal so as to make it incoherent or "noisy." One 
aspect of this "noise" is that it lessens data quality at stations near noisy structures. Other aspects of noise are more thoroughly discussed in the report.

A total of eight telluric profiles was measured across the Baca Prospect; locations of profile lines are given in Plate $I$. The lines varied in length from 1-13 km; seven lines were measured with stations spaced 1000 feet apart while the eighth profile, $\mathrm{H}$, utilized 500 foot stations for greater detail. Data quality throughout the time of the survey was generally good with signals much stronger on the north-south lines than the east-west. (This phenomenon is explained with the magnetotelluric results, Section IV). Data was taken in four discrete frequency bands for all profiles. These bands $(8 \mathrm{~Hz}, .5-2 \mathrm{~Hz}, .03-.06 \mathrm{~Hz}$, and .008$.045 \mathrm{~Hz}$ ) provide variable depth recordings beneath each site.

Plates II-VII show the results of telluric profiles. On each is indicated all the necessary data for qualitative interpretation, including a topographic profile, a J-value profile and an interpreted subsurface pseudosection. Faults are noted by their telluric signature as o (conductive) or $p$ (resistive). The scale of these plates is the same as the base map. Topographic corrections were not taken except for a mathematical correction of line lengths; in most cases this is no setback since the correlation between high frequency tellurics and topography is usually apparent, while low frequency telluric topography corrections are not significant.

Twenty-five magnetotelluric sites were occupied in the Baca Prospect in July 1976. Four additional planned sites were to be occupied in December 1976. Data quality was generally good but signals were low. Interpretable data was extracted from all but three stations. It was computer analyzed and evaluated by polarization, apparent resistivity and modeled resistivity values. 
SECTION

PAGE

I. INTRODUCTION

Description of the Prospect 1

Data Acquisition and Reduction 1

II. GEOLOGY AND GEOPHYSICS 4

Pertinent Features 4

Effect of the Geologic Structure on the Present Survey 5

III. TELLURIC PROFILE RESULTS 6

Profile A (Plate II) $\quad 6$

Profile B (Plate III) 7

Profile C (Plate IV)

Profiles D and H (Plate V)

$\begin{array}{lr}\text { Profiles F and E (Plate VI) } & 10\end{array}$

$\begin{array}{ll}\text { Profile G (Plate VII) } & 11\end{array}$

IV. TELLURIC NOISE ANALYSIS 12

V. MAGNETOTELLURIC RESULTS 15

$\begin{array}{ll}\text { Model Curves } & 17\end{array}$

VI. TELLURIC-MAGNETOTELLURIC RESULTS 23

MT Profile B (Plate IX) $\quad 23$

MT Profile D (Plate: $X) \quad 24$

MT Profile G (Plate XI) 24

VII. REFERENCES 26 
LIST OF APPENDICES OF THE REPORT

PAGE

APPENDIX I. FIELD DATA FOR MAGNETOTELLURIC

SOUNDINGS

APPENDIX II. MAGNETOTELLURIC APPARENT RESISTIVITY CURVES

106

APPENDIX III. THE MAGNETOTELLURIC METHOD

134

APPENDIX IV. THE TELLURIC METHOD 


\section{LIST OF FIGURES OF THE REPORT}

FIGURE

PAGE

1 Prospect location map of the Valles Caldera prospect, New Mexico.

2 Strip chart records from a quiet (A) and a noisy (B) telluric profile station.

$3 \quad$ MT station locations. 


\title{
LIST OF PLATES OF THE REPORT
}

\author{
PLATE \\ NUMBER \\ I Telluric and Magnetotelluric Station Location Map \\ II Telluric Profile A \\ III Telluric Profile B \\ IV Telluric Profile C \\ $\mathrm{V} \quad$ Telluric Profiles $\mathrm{D}$ and $\mathrm{H}$ \\ VI Telluric Profiles $\mathrm{F}$ and $\mathrm{E}$ \\ VII Telluric Profile G \\ VIII Telluric Noise Histogram \\ IX Magnetotelluric Profile B \\ X Magnetotelluric Profile D \\ XI Magnetotelluric Profile G
}


SAMPLES OF DATA SHEETS AND GRAPHS 


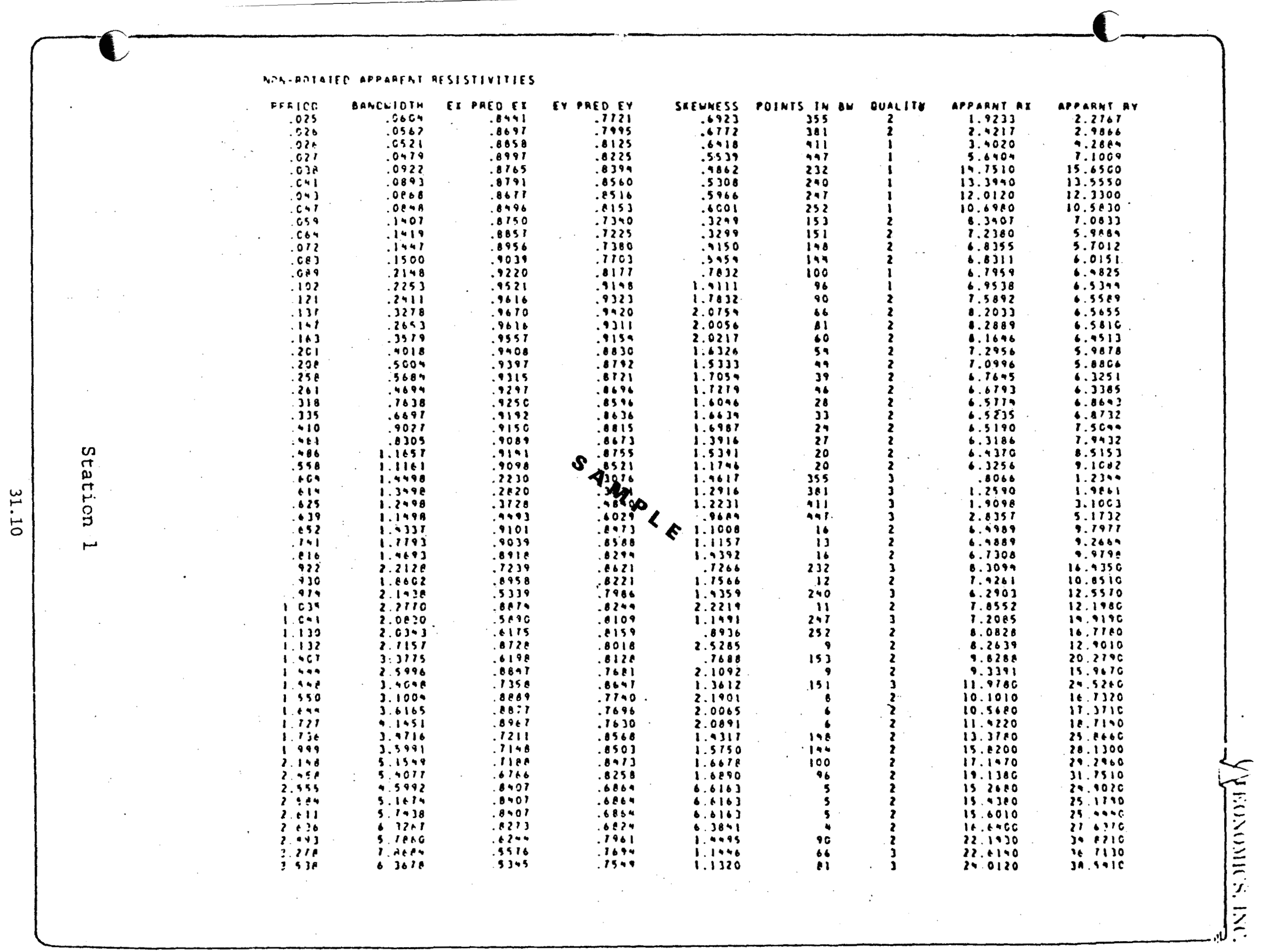




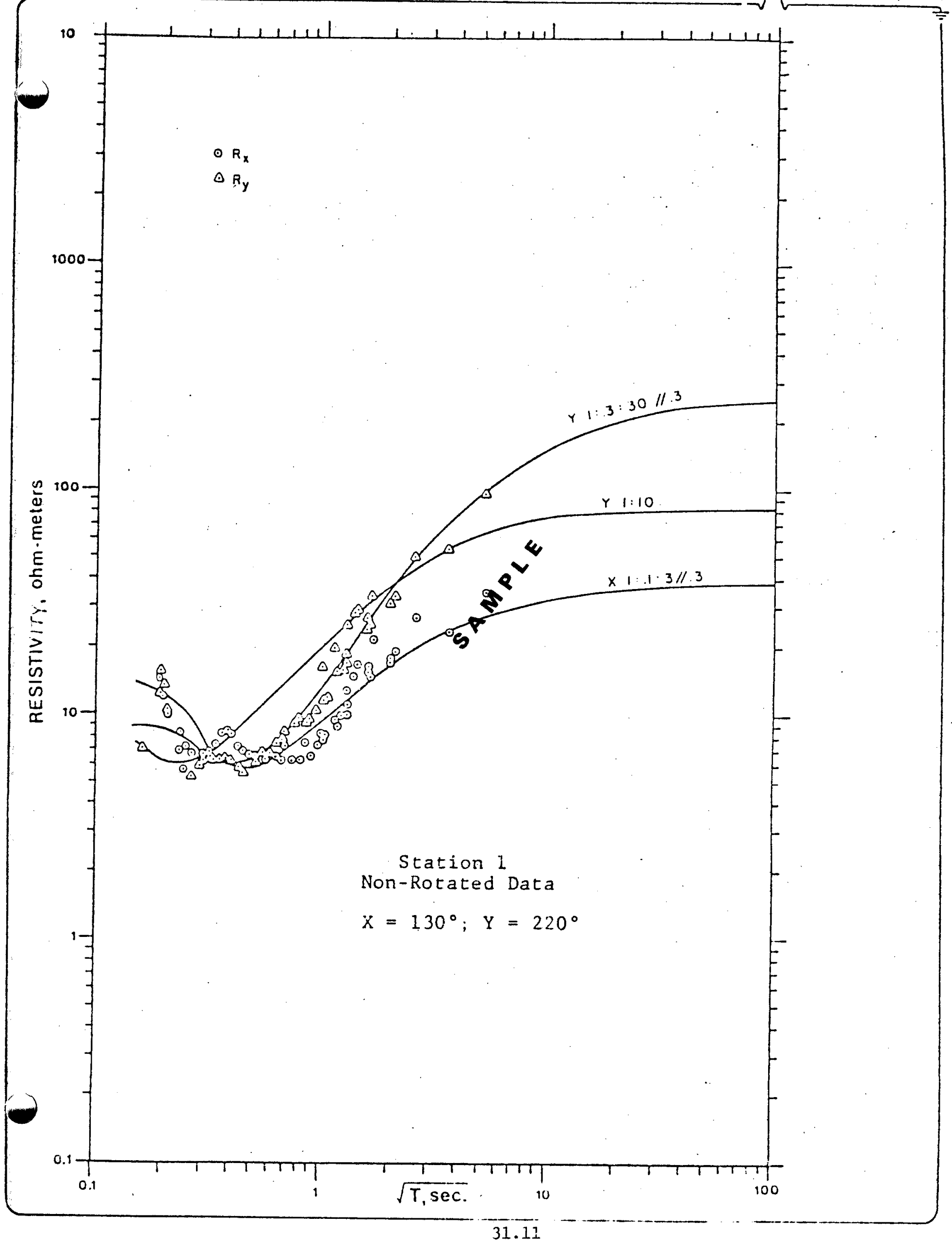


REPORT NO. 32

EXECUTIVE SUMMARY

\section{GEOLOGICAL RESUME OF THE VALLES CALDERA}

\section{FROM A REPORT}

Prepared By

T.R. Slodowski

UNION GEOTHERMAL DIVISION

UNION OIL COMPANY OF CALIFORNIA

LOS ANGELES, CALIFORNIA

JUNE 1977

Summary Prepared By

WESTEC SER VICES, INC.

ALBUQUERQUE, NEW MEXICO

JUNE 1980 


\begin{abstract}
In 1977, T.R. Slodowski of Union Oil Company compiled a summary of existing knowledge of the historical geology and present day geothermics of the Valles Caldera in north-central New Mexico. This summary contains synopsized information on the present regional geology, stratigraphy through the PreCambrian, Paleozoic, Tertiary, and Quaternary periods, and the present day stratigraphy and geothermics of the area. References are cited throughout the text of this documentary. This report contains six reference maps.
\end{abstract}


Geological studies performed from 1968 to 1977 and geological and geophysical observations by Union Oil Company of the Valles Caldera of north-central New Mexico are summarized in this report. Extensive attention is given to the chronology of the formation of the caldera and its stratigraphic layering or lack of it. The report includes a detail of the structure developed during the Pre-Cambrian, Paleozoic, Tertiary and Quaternary periods. The area geothermics and results of exploration activities are discussed.

\subsection{SUMMARY AND CONCLUSIONS}

The Valles Caldera (Figures 2, 3, 4, and 5 ) is a subcircular, volcanic depression 12 to 15 miles in diameter, with its walls rising from a few hundred to more than 2000 feet above the floor. A central structural dome, Redondo Peak, near the center of the caldera has a relief of nearly 3000 feet and is bisected by a northeasterly-trending central graben. Over ten large rhyolite volcanic domes are located on or close to a ring-fracture zone circling the central dome; caldera collapse occurred along this fracture zone.

At the date of this report, 16 geothermal exploration wells had been drilled in the Valles Caldera; 5 in the Sulphur Springs area and the remainder in Redondo Creek. The wells vary in depth from a little over 2000 feet to a maximum depth of 9212 feet. Although very high temperatures have been found in all wells, exploration activity had been concentrated in the Redondo Creek area because of the thicker section of Bandelier Tuff present there and the fracture permeability it possesses. Almost all the production comes from this formation.

The principal geothermal resource discover ed is a deep reservoir of hot water with temperatures varying from $535 \mathrm{~F}$ to $627 \mathrm{~F}$. Permeable reservoir rock is not usually found above depths of 3000 feet. The water contains about $7000 \mathrm{ppm}$ total dissolved solids. The chemistry of thermal water from a typical well is given in the report. 


\section{PAGE}

Regional Geology 1

Valles Caldera $\quad 2$

Stratigraphy $\quad 2$

Pre-Cambrian 2

Paleozoic $\quad 3$

$\begin{array}{lc}\text { Tertiary } & 3\end{array}$

$\begin{array}{ll}\text { Quaternary } & 4\end{array}$

$\begin{array}{lll}\text { Structure } & 6\end{array}$

$\begin{array}{lc}\text { Geothermics } & 8\end{array}$

References 11

FIGURES

1 Regional Geologic Map

$2 \quad$ Geothermal Features, Jemez Mountains

3 Geologic Map - Valles Caldera

4 Geologic Section $A-A^{\prime}$, Valles Caldera

$5 \quad$ Geologic Section B-B', Valles Caldera

6 Composite Stratigraphic Column - Redondo Creek Area 
REPORT NO. 33

EXECUTIVE SUMMARY

\section{GEOTHERMAL POWER PLANT}

FEASIBILITY REPORT

\section{FROM A REPORT}

Prepared For

UNION GEOTHER MAL DIVISION UNION OIL COMPANY OF CALIFORNIA LOS ANGELES, CALIFORNIA
Prepared By

ROGERS ENGINEERING COMPANY, INC.

SAN FRANCISCO, CALIFORNIA

OCTOBER 1974

Summary Prepared By

WESTEC SERVICES, INC.

ALBUQUERQUE, NEW MEXICO

JUNE 1980 


\begin{abstract}
This engineering feasibility report was prepared in October 1974 and presents economic and technical comparisons of the various alternatives available to industry at that time to utilize hot geothermal brines for electrical power generation.

The evaluation of alternatives was based on geothermal brine qualities and well productivity data obtained from the exploratory wells, Baca 4, 6 and 11, located in the Redondo Creek area of the Baca Location No. 1, New Mexico. The analysis proceeds through conceptual designs and cost estimates for single flash, double flash and binary cycle power plants, conceptualization of fixed and variable operations and maintenance costs, electric utility interconnection costs, and incremental environmental protection costs. Conclusions and recommendations are presented based on this analysis.
\end{abstract}


This engineering feasibility report was prepared in October 1974 and presents economic and technical comparisons of the various alternatives available to industry at that time to utilize hot geothermal brines.

The evaluation of alternatives was based on geothermal brine qualities and well productivity data obtained from the exploratory wells, Baca 4, 6 and 11, located in the Redondo Creek area of the Baca Location No. 1 , New Mexico. The power plant options considered were based on the current state of available geothermal power plant technology along with the availability of hardware. Each of the power producing cycles considered was evaluated in mid-1975 dollars based on a $50 \mathrm{MW}$ plant size.

The scope of the feasibility report includes:

i. The determination of the cost benefits of a single flash steam power plant; double flash steam power plant utilizing mixed pressure, multi-stage, condensing turbines; and the binary fluid cycle power plant, based on the "Magmamax Power Cycle."

2. The development of cost estimates for the flash steam and binary cycle power plants, which were prepared after each system, was designed to economically utilize the geothermal resource conditions prevailing at the site.

3. The development of cost estimates for additions or modifications to the power plant for environmental protection. These estimates were done on an incremental cost basis. The additions or modifications for environmental protection which have been evaluated include:

a. The use of dry cooling towers combined with direct contact condensers to eliminate atmospheric discharges of water vapor and noncondensible gasses.

b. The use of surface condensers in conjunction with wet cooling towers, to eliminate direct contact absorption of hydrogen sulfide into the cooling water, and thereby eliminate atmospheric contamination.

c. The use of a Stretford unit for the absorption of hydrogen sulfide from the condenser vacuum system vent gasses and the reduction of the hydrogen sulfide to elemental sulfur.

2.0 SUMMARY AND CONCLUSIONS

The results of the feasibility analysis of $50 \mathrm{MW}$ power plant alternatives using geothermal fluids from Baca wells 4,6 and 11, show that: 
1. The Single Flash Steam Cycle power plant is about four percent (4\%) lower in capital cost than the Double Flash Steam Cycle plant. However, the Single Flash Steam Cycle power plant requires about twenty-one percent (21\%) more geothermal well production for the same power output. The Single Flash Steam power plant is the more common type of geothermal power plant operating on geothermal hot brine, and it has a longer operating history. However, there are $90 \mathrm{MW}$ of Double Flash Steam Cycle power plants in operation at Power Station No. 2, Wairakei, New Zealand. Indications are that these plants have comparable operating load factors.

2. Turbine-generators for either single or double flash plants can be obtained in various sizes and from different manufacturers. Therefore, the decision regarding which type of plant to install should be based on an evaluation of the operating cost for the twenty-one percent $(21 \%)$ increase in well production versus the four percent (4\%) increase in plant investment.

3. The removal of noncondensible gasses from the main condenser requires about 94,000 pounds per hour of steam for steam jet gas ejectors in the Single Flash Steam Cycle plant. The same noncondensible gas removal using motor driven compressors would require $900 \mathrm{KW}$ of electrical energy. The incremental capital cost of the gas ejector system is $\$ 542,000$ while the cost of the gas compressor installation is $\$ 1,640,000$. Based on the high cost and increased maintenance required for the gas compressors relative to the steam ejectors, it does not appear feasible to buy and use compressors for noncondensible gas removal unless steam (fuel) values are high. For the purposes of these cost estimates steam (fuel) values are assumed to be high. The steam jet ejectors were included, however, on the flow sheets to provide a backup when the gas compressors are down for maintenance. The cost estimates for the power plants include the costs for both the gas compressors and the steam jet ejectors. If the high steam cost assumptions are not borne out, the power plant capital costs may be reduced by $\$ 1,640,000$ each, based on the use of steam jet. ejectors alone.

A combination of steam jet ejectors and compressors may ultimately be justified. The first stage compressor costs about sixty percent $(60 \%)$ of the total, but the motive steam to each ejector stage is about equal, so the use of a steam jet on the first stage and a gas compressor on the seond stage may prove to be the most economical arrangement.

4. The binary cycle plant costs about forty-five percent (45\%) more than either the Single or Double Flash Steam Cycle power plants. Aside from its high first cost, the binary fluid cycle power plant 
has no commercial operating experience. Therefore, there is no way to assess the cycle's performance or the reliability of the plant. The consideration of the type of power plant to be constructed at this time should be limited, therefore, to the Single or Double Flash Steam Cycle power plant. With a savings of twentyone percent (21\%) in well production cost at a difference of four percent (4\%) in plant investment, the Double Flash Steam Cycle power plant is recommended.

5. Hydrogen sulfide contamination at the cooling tower may be prevented by utilizing a closed condensing system. This can be accomplished by use of a surface condenser combined with a wet cooling tower or by use of a dry cooling tower combined with a direct contact condenser. The incremental cost increases to convert to the closed condensing system were calculated.

The combination of the surface condenser and the wet tower is recommended because its incremental cost is approximately twenty-four percent (24\%) of the cost of the direct contact condenser with dry cooling tower, and also gives better plant performance.

6. The hydrogen sulfide discharged from the condenser vents can be treated by adding a Stretford process unit. The cost of this unit is $\$ 1,450,000$. Operating costs are approximately $\$ 31$ per day for chemicals, and power consumption is approximately $130 \mathrm{KW}$. 
TABLE OF CONTENTS OF THE REPORT

SECTION

TITLE

1.0 INTRODUCTION AND SCOPE

2.0 SUMMARY

3.0 DISCUSSION OF COST ESTIMATE

3.1 General Considerations

3.2 Cost Estimate Single or Double Flash Cycles

3.3 Cost Estimate Binary Cycle Plant

3.4 PG and E Geysers Unit 15 Costs

3.5 Unit Size Cost Considerations

$4.0 \quad$ CONSTRUCTION SCHEDULE

5.0 BASIS FOR DESIGN
$5.1 \quad$ Site
5.2 Building Design
5.3 Weather Data
5.4 Geothermal Well Data
5.5 Electrical

6.0 POWER GENERATING CYCLES
6.0.1 Geothermal Considerations
6.1 Single Flash Steam Cycle
6.2 Double Flash Steam Cycle
6.3 Binary Fluid Cycle

7.0 GEOTHERMAL POWER PLANT OPERATION AND MAINTENANCE

$\begin{array}{ll}\text { 7.1 Operating and Maintenance Personnel Costs } \\ 7.2 & \text { Maintenance Yearly Turnaround Personnel } \\ \text { and Costs } & \\ 7.3 & \text { Analysis of Fixed Operating Costs per Year }\end{array}$

8.0 ELECTRIC UTILITY INTERCONNECTION
3.1 Assumed Interconnection
8.2 Future Increased Generation
8.3 Design Factors Influenced by Connecting
8 Utility
8.4 Estimated Electric Loads and Resources
8.5 Transmission Line Estimated Cost 
TABLE OF CONTENTS OF THE REPORT (Continued)

SECTION

TITLE

9.0 ENVIRONMENTAL PROTECTION

9.1 Hydrogen Sulfide Abatement

9.2 Water Vapor Abatement 
DRAWING LIST FROM THE COMPLETE REPORT

NUMBER DRAWINGS

E-07-001 Schedule, Design \& Construction

E-02-002 Power Cycle Flow Diagram - Single Flash Steam Cycle

E-17-002 Single Line Power Diagram - Single Flash Steam Cycle

E-02-001 Power Cycle Flow Diagram - Double Flash Steam Cycle

E-04-001 Plot Plan

E-04-002 Power House Operating Floor Plan

E-04-003 Power House Operating Floor Plan

E-04-004 Power House Ground Floor Plan

E-42-001 Power House Traverse Section

E-42-002 Power House Cross Section

E-42-003 Elevations

E-17-001 Single Line Power Diagram - Double Flash Steam Cycle

E-17-201 Single Line Meter \& Relay Diagram

E-02-101 Combined Flow Diagram and P \& ID Binary Power Cycle

E-04-005 Plot Plan Binary Cycle Geothermal Plant

E-17-101 Single Line Power Diagram - Binary Cycle

SK-P1 Noncondensable Gas Purification - Stretford Process 
REPORT NO. 34

EXECUTTVE SUMMARY

BACA WELL NO. 11

SCALE EVALUATION

FROM A REPORT

Prepared By

UNION GEOTHERMAL DIVISION

UNION OIL COMPANY OF CALIFORNIA

LOS ANGELES, CALIFORNIA

APRIL 1975

Summary Prepared By

WESTEC SERVICES, INC.

ALBUQUERQUE, NEW MEXICO

FEBRUARY 1980 


\begin{abstract}
Erratic flow characteristics of Baca Well No. 11 in the Redondo Creek Area, New Mexico, in the latter part of August and September of 1974, necessitated a thorough inspection of surface and subsurface facilities. This inspection disclosed the presence of scale in both locations. Scale had been noted prior to this on the coils of the test heat exchanger which were in contact with the wellbore fluids. This report was prepared to consolidate all information existing at the time relating to the scale problem for purposes of information, analysis of the problem, possible effects on the project, and to provide a basis for recommendations for further evaluation.
\end{abstract}


Erratic flow characteristics of Baca Well No. 11 in the latter part of August and September 1974 necessitated a thorough inspection of surface and subsurface facilities. This inspection disclosed the presence of scale in both locations. Scale had been noted prior to this on the coils of the test heat exchanger which were in contact with the wellbore fluids.

This report has been prepared to consolidate all information relating to the scale problem for purposes of information, analysis of the problem, possible effects on the project, and to provide a basis for recommendations for further evaluation. The report analyzes the drilling and production histories of Baca Well No. 11, and compares the results to those observations made in other wells in the area.

\section{SUMMARY AND CONCLUSIONS}

The formation scale was verified downhole in the bore of Baca Well No. 11, in the Redondo Creek area, New Mexico Project. The scale was found to be primarily calcium carbonate, with possibly some silica associated. This situation, along with Union Oil Company scale experience in the Philippines, indicates that scaling tendencies may be present in all hot water geothermal wells. An economical and practical solution for the problem must be found in order to have a viable geothermal project.

Recommendations are made which form a consensus of opinion of research and operations personnel as to the best methods to attack the problem here and at other projects. Most recommended testing was to be done at the Baca Location site in New Mexico because of better logistics.

Briefly, the main emphasis of recommended testing was to involve the development of scale prediction capabilities, the magnitude of mechanical scale removal required for uncontrolled scale formation, scale inhibitor injection testing, investigation of a removable, disposable liner, and the use of downhole pumps. Some conclusions were made, but only to discard possible solutions to the scale problem. 
Introduction

Conclusions \& Recommendations

Drilling History

Production History

Comparison With Other Wells

Heat Exchanger Test

1

2

6

9

15

18

\section{APPENDIX OF THE REPORT}

Diagrammatic Sketch of Baca Well No. 11 Completion

Baca Well No. 11 Production Graph

Baca Well No. 11 Separator Scale Analyses

Baca Well No. 11 Wellbore Scale Analyses

Baca Well No. 6 Liner Examination

R.F. Donanville Silica Memo

Baca Well No. 11 Pressure Buildup Graph

Baca Well No. 11 Pressure Versus Depth Graph

Baca Well No. 4 Water Analyses

Baca Well No. 5A Water Analyses

Baca Well No. 6 Water Analyses

Baca Well No. 8 Water Analyses

Baca Well No. 11 Water Analyses

Baca Well No. 13 Water Analyses

Baca Well No. 4 Non-Condensible Gas Analyses

Baca Well No. 6 Non-Condensible Gas Analyses

Baca Well No. 11 Non-Condensible Gas Analyses

Baca Well No. 13 Non-Condensible Ges Analyses

Mechanical Well Bore Scale Removal Proposal

Figure I

Figure II

Figure III

Figure IV

Figure $\mathrm{V}$

Figure VI

Figure VII

Figure VIII

Figure IX

Figure $X$

Figure XI

Figure XII

Figure XIII

Figure XIV

Figure XV

Figure XVI

Figure XVII

Figure XVIII

Figure XIX 
REPORT NO. 35

EXECUTIVE SUMMARY

EFFECTS OF TURBINE POWER CYCLE

ON DEVELOPMENT WELL REQUIREMENTS

IN THE REDONDO CREEK AREA

FROM A REPORT

Prepared By

J.D. Hartz

UNION GEOTHERMAL DIVISION

UNION OIL COMPANY OF CALIFORNIA

LOS ANGELES, CALIFORNIA

OCTOBER 1977

Summary Prepared By

WESTEC SERVICES, INC.

ALBUQUERQUE, NEW MEXICO

JUNE 1980 


\begin{abstract}
This report presents a brief review of productivity and reservoir data from the Redondo Creek area wells and discusses the Union Oil Company concept of initial development of the project. Mass balance calculations are included to show how well productivity and produced enthalpy affect the number of wells that would be required to develop steam for a $50 \mathrm{MW}$ single-flash or dual-flash turbine generator. Noncondensible gas and steam condensate data are included to provide a basis for preliminary turbine design.
\end{abstract}


Production testing at Baca Well No. 15 has indicated that it should be considered a relatively high steam producer with high steam fraction and resultant high enthalpy compared to the other wells in the Redondo Creek area. Two figures plot deliverability, produced enthalpy and steam fraction versus wellhead pressure. Geologic and reservoir data indicated that the area northwest of Baca Well No. 15 may be underlain by a steam cap or steam reservoir but the reservoir geologists are unable to determine its size or extent from the current data.

A development forecast has been made utilizing production and reservoir data from 1975-1976 interference tests. The report relies in part on the Rogers Engineering Feasibility Study of October 1974, and briefly reiterates some of the findings of the study. Mass balance calculations were made to determine well requirements for $50 \mathrm{MW}$ single and dual-flash steam systems. The author included a self-imposed 10 percent excess steam requirement, which was not considered in the Rogers study.

\subsection{SUMMARY AND CONCLUSIONS}

The reservoir and productivity data developed at this time indicate the presence of a steam-dominated reservoir in the area of Baca 15 in addition to the liquid-dominated reservoir as penetrated by Baca 4, 6, 11 and 13. Calculations of development well requirements based on observed productivity lead to conclusions listed in the text. Briefly, the author calculated that 13 wells would be required to supply fluids to a plant using a single-flash system, while a dual-flash system would require one less well. However, it was found that the savings due to the lesser well requirement would be offset by: 1) higher gathering system costs which would include an automated crossover; 2) the costs of duplication of facilities if separate gathering systems are used; 3) complications in balancing the two stages which may result in lower turbine efficiency and capacity factor; and 4) the possibility of finding difficulty in achieving proper excess or backup steam requirements.

Based on reservoir data, well productivity data, and simplicity of design and operation, the author found that a single-flash turbine would be better suited to the resource conditions in the Redondo Creek area. The operating pressure of the turbine was found to be optimal in the range of 100 to 110 psia. Further, the author recommended study of the feasibility of using steam ejectors or compressors to remove noncondensible gases because of the effects on steam requirements and capital costs. 


\author{
REPORT NO. 36 \\ EXECUTIVE SUMMARY
}

TEMPERATURE GRADIENT HOLE DATA

1970, 1972-1974 AND LOCATION MAP

FROM A REPORT

Prepared By

UNION GEOTHERMAL DIVISION

UNION OIL COMPANY OF CALIFORNIA

LOS ANGELES, CALIFORNIA

Summary Prepared By

WESTEC SERVICES, INC.

ALBUQUERQUE, NEW MEXICO

JUNE 1980 


\begin{abstract}
The report contains a tabular summary of about 55 gradient holes drilled in 1970, and survey data sheets for 66 gradient holes drilled in 1972, 1973, and 1974. The report also contains a location map for each of the wells mentioned. There is no text of discussion or summary. The area covered by the gradient hole grid is the general area of the Baca Geothermal Project/Generating Station, in the Valles Caldera.
\end{abstract}


SAMPLES OF DATA SHEETS

36.3 


\section{0 \\ Data On Shallow Temperature Holcs (100' Decp)}

iole

Number

Completed

Dates \& Temperatures

\begin{tabular}{|c|c|c|c|c|c|c|c|c|c|}
\hline$T-1$ & $11 A 6-23-70$ & $7-2$ & $43^{\circ}$ & $7-9$ & $43^{\circ}$ & & & & \\
\hline$T-2\left(58^{\prime}\right)$ & $12 N 6-24-70$ & $7-2$ & $45^{\circ}$ & $7-12$ & $45^{\circ}$ & & & & \\
\hline$T-3$ & $8 P 6-24-70$ & $7-2$ & $451 / 2^{\circ}$ & $7-13$ & $451 / 2^{\circ}$ & & & & \\
\hline$T-4$ & $11 A \quad 6-25-70$ & $7-2$ & $451 / 2^{\circ}$ & $7-8$ & $451 / 2^{\circ}$ & $7-12$ & $46^{\circ}$ & & \\
\hline$T-5$ & $12 N 6-25-70$ & $7-2$ & $45^{\circ}$ & $7-8$ & $45^{\circ}$ & $7-12$ & $44^{\circ}$ & & \\
\hline$T-6$ & $3 P 6-25-70$ & $7-2$ & $441 / 2^{\circ}$ & $7-8$ & $45^{\circ}$ & $7-12$ & $45^{\circ}$ & & \\
\hline$T-7$ & $7 P 6-25-70$ & $7-2$ & $43^{\circ}$ & $7-8$ & $43^{\circ}$ & $7-12$ & $43^{\circ}$ & & \\
\hline$T-8$ & $12 \mathrm{~N} 6-26-70$ & $7-2$ & $52^{\circ}$ & $7-8$ & $52^{\circ}$ & $7-12$ & $50^{\circ}$ & $7-29$ & $51^{\circ}$ \\
\hline$T-9$ & $5 P 6-26-70^{\circ}$ & $7-2$ & $48^{\circ}$ & $7-8$ & $47^{\circ}$ & $7-12$ & $48^{\circ}$ & & \\
\hline$T-10$ & $11 A 6-27-70$ & $7-2$ & $46^{\circ}$ & & & & & & \\
\hline$T-11$ & $3 P 6-27-70$ & $7-2$ & $44^{\circ}$ & & & & & & \\
\hline$T-12$ & $6 P 6-27-70$ & $7-2$ & $44^{\circ}$ & & & & & & \\
\hline$T-13$ & $2 P 6-29-70$ & $7-2$ & $46^{\circ}$ & & & & & & \\
\hline$T-14$ & $8 P \quad 6-29-70$ & $7-2$ & $461 / 2^{\circ}$ & & & & & & \\
\hline$T-15$ & $6 P 6-30-70$ & $.7-2$ & $541 / 2^{\circ}$ & $7-21$ & $57^{\circ}$ & & & & \\
\hline$T-16$ & $8 P 6-30-70$ & 7,2 & $58^{\circ}$ & & & & & & \\
\hline$T-1 T$ & $10 \mathrm{~A} 7-1-70$ & $7-2$ & $531 / 2^{\circ}$ & & & & & & \\
\hline$T-18$ & $12 N 7-1-70$ & $7-2$ & $67^{\circ}$ & $7-9$ & $67^{\circ}$ & & & & \\
\hline$T-19$ & $3 P 7-3-70$ & $7-6$ & $841 / 2^{\circ}$ & $7-7$ & $85^{\circ}$ & & & & \\
\hline-20 & $2 P 7-1-70$ & $7-3$ & $104^{\circ}$ & $7-6$ & $104^{\circ}$ & $7-7$ & $104^{\circ}$ & & \\
\hline$\Gamma-21\left(68^{\prime}\right)$ & $7 P 7-1-70$ & $7-3$ & $74^{\circ}$ & $7-6$ & $72^{\circ}$ & $7-7$ & $75^{\circ}$ & & \\
\hline$T-22$ & $3 P 7-6-70$ & $7-7$ & $85^{\circ}$ & & & & & & \\
\hline$T-23$ & $10 \wedge 7-2-70$ & $7-3$ & $86^{\circ}$ & $7-6$ & $87^{\circ}$ & $7-7$ & $871 / 2^{\circ}$ & & \\
\hline$T-24$ & $7 P 7-2-70$ & $7-3$ & $76^{\circ}$ & $7-6$ & $74^{\circ}$ & $7-7$ & $75^{\circ}$ & & \\
\hline$T-25$ & $9 P 7-2-70$ & $7-3$ & $731 / 2^{\circ}$ & $7-6$ & $731 / 2^{\circ}$ & $7-7$ & $74^{\circ}$ & . & \\
\hline$T-26$ & $10 \wedge 7-6-70$ & $7-7$ & $80^{\circ}$ & & & & & & \\
\hline$T-27$ & $12 N 7-6-70$ & $7-7$ & $691 / 2^{\circ}$ & $7-9$ & $70^{\circ}$ & & & & \\
\hline$T-28$ & $9 A \quad 7-7-70$ & $7-7$ & $781 / 2^{\circ}$ & $7-9$ & $82^{\circ}$ & & & & \\
\hline$T-2 !$ & $8 P 7-9-70$ & $7-10$ & $88^{\circ}$ & $7-14$ & $86^{\circ}$ & & & & \\
\hline$T-30 S\left(20^{\prime}\right)$ & $4 P 7-9-70$ & $7-10$ & $51^{\circ}$ & $7-14$ & $50^{\circ}$ & & & & \\
\hline$T-31\left(100^{\prime}\right)$ & $2 P 7-9-70$ & $7-10$ & $1051 / 2^{\circ}$ & $7-14$ & $1041 / 2^{\circ}$ & $7-22$ & $1051 / 2^{\circ}$ & & \\
\hline$T-315\left(20^{\prime}\right)$ & $3 P 7-9-70$ & $7-10$ & $56^{\circ}$ & $7-14$ & $56^{\circ}$ & & & & \\
\hline$T-32.5\left(20^{\prime}\right)$ & $10 \mathrm{~A} T-9-70$ & $7-10$ & $53^{\circ}$ & $7-14$ & $521 / 2^{\circ}$ & & & & \\
\hline$\Gamma-335\left(20^{\prime}\right)$ & $6 P 7-8-70$ & $7-10$ & $44^{\circ}$ & $7-14$ & $421 / 2^{\circ}$ & & & & \\
\hline $\mathrm{T}^{\prime}-34$ & $2 P 7-11-70$ & $7-12$ & $49^{\circ}$ & $7-13$ & $49^{\circ}$ & $7-15$ & $49^{\circ}$ & $7-29$ & $49^{\circ}$ \\
\hline$T-35$ & $4 P 7-12-70$ & $7-12$ & $46^{\circ}$ & $7-13$ & $45^{\circ}$ & $7-29$ & $45^{\circ}$ & & \\
\hline $\mathrm{T}-36$ & $12 N 7-11-70$ & $7-12$ & $48^{\circ}$ & $7-13$ & $48^{\circ}$ & $7-29$ & $47^{\circ}$ & & \\
\hline$T-37$ & $12 N 7-14-70$ & $7=16$ & $47^{\circ}$ & $7-29$ & $45^{\circ}$ & & & & \\
\hline$T-38$ & $11 \wedge 7-13-70$ & $7-15$ & $44^{\circ}$ & & & & & & \\
\hline$T^{\prime} .33$ & $9 \wedge 7-14-70$ & $7-15$ & $57^{\circ}$ & $7-16$ & $\therefore 591 / 2^{\circ}$ & $7-29$ & $581 / 2^{\circ}$ & & \\
\hline$\Gamma-40$ & $5 P 7-14-70$ & $7-15$ & $46 ! / 2^{\circ}$ & $7-29$ & $-58-1+20$ & & & & \\
\hline-11 & $11 \wedge 7-15-70$ & $7-16$ & $47^{\circ}$ & -3 & $-16 \cdot 1_{2}$ & - & & & \\
\hline $1-42$ & $1 P 7-1+-70$ & $7-15$ & $46^{\circ}$ & & & & & & \\
\hline$\Gamma .43$ & $3 P 7-1+-70$ & $7-15$ & $46^{\circ}$ & . & & & & & \\
\hline$T-44$ & $9 \wedge 7-16-70$ & $7-29$ & $52^{\circ}$ & & & & & & \\
\hline
\end{tabular}


Hole

Number

Completed

Dates \& Temperatures

$T-45$

$T-46$

$3 P 7-15-70$

$12 N 7-16-70$

$7-1647^{\circ}$

$T-47$

$\mathrm{T}-48$

$10 A-16-70$

$7-1747^{\circ}$

$7-1747^{\circ}$

$9 A \quad 7-17-70 \quad 7-1950^{\circ}$

$5 P 7-17-70$

$7-2046^{\circ}$

$T-50-D$ (300' Hole Twin Lo T-31)

$\mathrm{T}-51$

$8 \mathrm{P} 7-23-70$

$7-24202^{\circ}$

$12 \mathrm{~N} 7-24-70$

$7-2597^{\circ}$

7 P $7-24-70$

$7-2565^{\circ}$

T-52-D (300' Holc)

3P $7-27-70$

$7-28107^{\circ}$

$7-20431 / 2^{\circ}$

$7-20,50^{\circ}$.

T-8-D (300' Hole)

$T-53$

$11 \mathrm{~A} 7-30-70$

$7-3172^{\circ}$

3P $8-4-70$

$8-654^{\circ}$

$7-25205^{\circ}$

$7-2892^{\circ}$

$8-2114^{\circ}$ 


$$
\begin{aligned}
& \frac{5-23-72}{5 \text { PUO DAÍ́ }}-1130 \\
& \frac{5-23-72}{\text { COMPLETION }}
\end{aligned}
$$

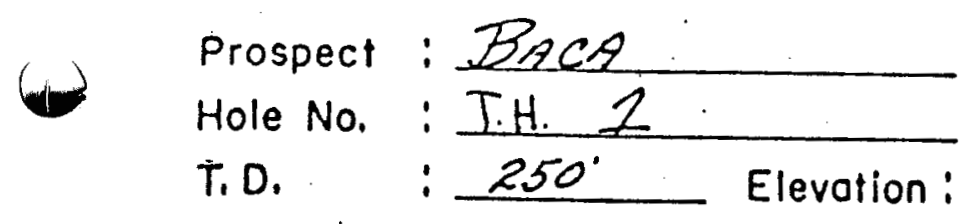
Gradient : $32 \mathrm{~F} / 100 \mathrm{ft} \quad$ Interval : $150-250 \mathrm{ft}$.
Temp.

BH Grodient : $32 \quad F \% 100 \mathrm{ft} . \quad$ Interval : $160-250 \mathrm{ft}$.

Mox. Temp. : $134 F^{\circ}$ at $250 \mathrm{ft}$.

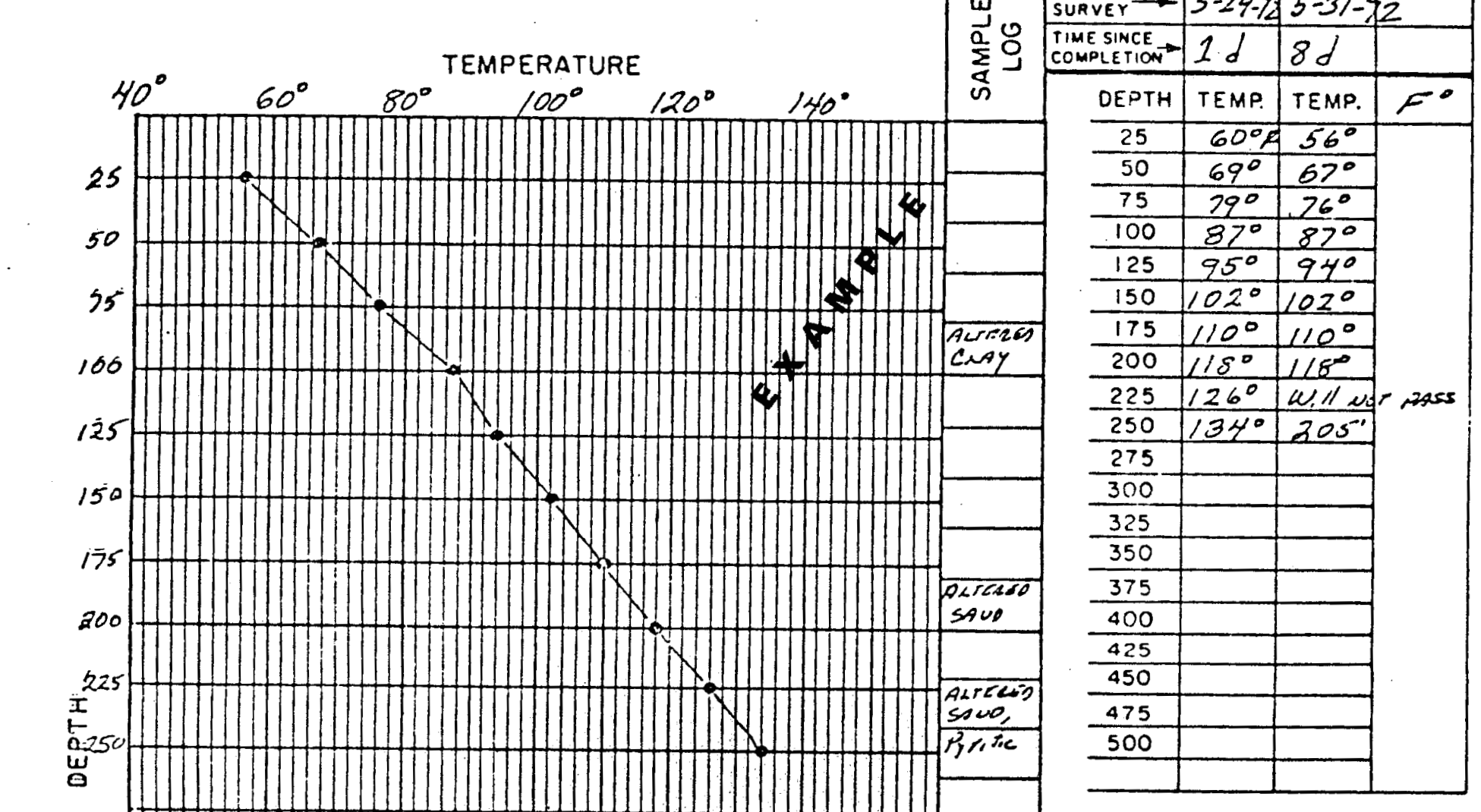

MRT :

Remorks: SUAPHe CREE, TwiU rolfer $\%$ 
REPORT NO. 37

EXECUTIVE SUMMARY

\section{BACA PROJECT INTERIM REPORT \\ OF TEST RESULTS}

FROM A REPORT

Prepared By

A.J. Chasteen

UNION GEOTHERMAL DIVISION

UNION OIL COMPANY OF CALIFORNIA

LOS ANGELES, CALIFORNIA

1974

Summary Prepared By

WESTEC SERVICES, INC.

ALBUQUERQUE, NEW MEXICO

JUNE 1980 


\begin{abstract}
This report presents the results of drilling and testing six geothermal wells in the Redondo Creek area of the Baca prospect. Of the twelve wells that had been drilled in the Valles Caldera as of the date of this report, six had been drilled in the steam productive Redondo Creek area. It is those six wells which are the subject of this report. The conclusions contained in this report were based on the data from the first twelve wells drilled in the Valles Caldera. Since the date of this report, substantially more wells have been drilled which will yield further data on the reservoir.
\end{abstract}


Exploration on the Baca Ranch began with the drilling of Bond \#1, an oil exploration well, by the Westates Petroleum Company in 1960. The well encountered shows of geothermal steam production and active geothermal steam exploration began with the drilling of Baca \#1 by the Baca Land and Cattle Company in 1963. The Baca Land and Cattle Company drilled three more exploration wells before Union Oil Company took over with the drilling of Baca \#5 in 1971. Since that time, Union has drilled six more wells. A summary of these wells is included as Figure 1 and a map showing their locations is included as Figure 2.

Of the twelve wells drilled thus far, six of them have been drilled in the steam productive Redondo Creek area. It is these six wells which are the object of this report.

\subsection{SUMMARY AND CONCLUSIONS}

This report presents the results of drilling and testing six geothermal wells in the Redondo Creek area of the Baca prospect. An analysis of these data, in conjunction with geologic information, indicates the existence of $5.55 \times 10^{12}$ lbs. of liquid reserves within the 2560 acre area which has so far been defined as productive. This is over seven times the amount of fluid required to supply a $50 \mathrm{MW}$ pilot generating plant for 30 years. To date, however, only one well produces at a high enough rate to be regarded as commercial. Further drilling is necessary to confirm that commercial wells can be drilled in the Redondo Creek area. 
PAGE

Summary

Introduction

Reservoir Description

Reserves Estimate

Drilling Program

Well Testing

Baca 4

Baca 5A

Baca 6

Baca 9

Baca 10

Baca 11

Chemical Composition

Heat Exchanger Test

Recommendations for Future Work

2

3

5

6

8

Well Summary

Map (Back Flap)

Separator (Back Flap)

Calendar of Events

Baca 4 Flow Test

Baca 6 Flow Test

Baca 11 Flow Test

Baca 4 Pressure \& Temperature Summary

Baca 5 Pressure \& Temperature Summary

Baca 6 Pressure \& Temperature Summary

Baca 10 Pressure \& Temperature Summary

Baca 11 Pressure \& Temperature Summary

Baca 10 Temperature Gradient

Baca 11 Pressure Build-Up

Baca 11 Pressure Gradient

Chemical Analysis Summary

Figure 1

Figure 2

Figure 3

Figure 4

Figure 5

Figure 6

Figure 7

Figure 8

Figure 9

Figure 10

Figure 11

Figure 12

Figure 13

Figure 14

Figure 15

Figure 16

Well Schematics

Appendix I

Flow Rate Tabulations

Research Department Report on Heat Exchanger Test

Appendix II

Appendix III 


\author{
REPORT NO. 38 \\ EXECUTIVE SUMMARY \\ SPECIAL CORE ANALYSIS STUDY \\ FOR UNION OIL COMPANY \\ BACA NO. 13 WELL \\ REDONDO CREEK FIELD, NEW MEXICO
}

FROM A REPORT

Prepared For

UNION GEOTHER MAL DIVISION

UNION OIL COMPANY OF CALIFORNIA

LOS ANGELES, CALIFORNIA
Prepared By

CORE LABORATORIES, INC.

PETROLEUM RESERVOIR ENGINEERING

DALLAS, TEXAS

1975

Summary Prepared By

WESTEC SERVICES, INC.

ALBUQUERQUE, NEW MEXICO

JUNE 1980 


\begin{abstract}
Presented in this report are the results of formation resistivity and acoustic velocity measurements. The samples used in this study are identified and lithologically described. This report concerns itself with core sample analyses of Baca Well No. 13. The study was completed in March 1975. Portions of the reproduced report are difficult to read due to poor original quality.
\end{abstract}




\subsection{INTRODUCTION AND SCOPE}

In preparation for this study, cylindrical plug-size samples, one inch in diameter, were drilled from full-diameter core segments recovered from the subject well. The samples used for electrical measurements were drilled parallel to the bedding and the samples used for acoustic velocity measurements were drilled perpendicular to the bedding planes. All test samples were thoroughly cleaned and dried; then air permeabilities and Boyle's Law porosities were measured. These measurements were verbally transmitted to a representative of Union Oil Company of California, and samples were selected for further testing. Selected samples were evacuated and saturated with simulated formation water synthesized from a water analysis submitted for use in this study.

Electrical resistivities of both the brine and the brine-saturated samples were measured. These measurements were repeated until the results stabilized, indicating ionic equilibrium within the core sample. The test samples were then desaturated by capillary displacement, and electrical resistivities of the samples were measured at equilibrium saturation conditions. The results of these measurements appear in both tabular and graphical form.

\subsection{SUMMARY AND CONCLUSIONS}

The formation resistivity factor-porosity relationship yields a cementation exponent " $m$ " of 2.10. This was obtained by drawing a visual bestfit line through the data points plotted on log-log paper. All samples contain pyrite and this mineral could influence the measurements considerably. A composite plot of resistivity measurements versus water saturations yielded a saturation exponent " $n$ " of 1.92 .

The brine-saturated vertical (perpendicular to the bedding planes) plugs selected for acoustic velocity measurements were confined hydraulically and transit times were measured at several effective overburden pressures while maintaining zero psi pore pressure. These results are presented in both tabular and graphical form. 
REPORT NO. 39

EXECUTTVE SUMMARY

BACA RESERVOIR STUDIES

FROM A REPORT

Prepared By

M.S. Gulati

UNION GEOTHERMAL DIVISION

UNION OIL COMPANY OF CALIFORNIA

LOS ANGELES, CALIFORNIA

1975

Summary Prepared By

WESTEC SERVICES, INC.

ALBUQUERQUE, NEW MEXICO

JUNE 1980 


\begin{abstract}
This report consists of a compilation of seven interdepartmental memos documenting separate studies by the author all concerning the Geothermal Reservoir at the Baca Location in New Mexico. All of the memos are dated in late August 1975. The subjects of the studies are: reservoir datum pressures, tests which will and will not yield reservoir information from hot water wells, the role of heat transfer in the pressure build-up in hot water wells, pressure build-up and drawdown studies in Baca Well No. 6, and individual pressure build-up studies for Baca Wells No. 11, 13, and 15. Each study appears to be well documented. Most discussions include data organized in tables and results of calculations in graphs.
\end{abstract}


In August 1975, M.S. Gulati, an employee of Union Oil Company of California, compiled a series of seven interdepartmental memorandums addressed to A.J. Casteen. The purpose of the seven memorandums was likely to document the geophysical work completed by M.S. Gulati to that date. All of the studies included in the report are directly or indirectly related to the geology and geophysics of the Baca Location geothermal anomaly in New Mexico.

\section{$2.0 \quad$ SUMMARY AND CONCLUSIONS}

The seven memorandums which form this report answer many questions for the Baca Location anomaly which arise in most geophysical reservoir investigations.

In the first memorandum, Gulati has compiled and summarized well pressure data and has interpreted the results to yield datum pressures, i.e., well pressure at a given elevation.

The second memorandum, entitled, "Obtaining Reservoir Information from Hot Water Wells - Tests that Work and Tests that Won't Work" documents research by Gulati where he examined the types of information available versus required results from that information. For example, he has gone into great detail on pressure measurement both static and transient, and elaborates on the types of reservoir information which can be deduced from pressure data.

Third in the series is a memorandum entitled, "The Role of Heat Transfer in the Pressure Build-Up in the Hot Water Wells." Gulati has summarized pressure data and has come to conclusions as to how heat transfer in the reservoir affects the pressure in some of the wells at the Baca Location before, during and after the well has been produced. Darcy's Law is used in the analysis.

Section four is a memorandum on pressure build-up and drawdown studies in Baca Well No.6. The balance of the memorandums document related studies on pressure build-up tests in Baca Wells No. 11, 13, and 15. The memorandums include data, calculations and graphical representations of the results. 
SECTION I

SECTION II

SECTION III

SECTION IV

SECTION V

SECTION VI

SECTION VII
Datum Pressures in Baca, N.M.

Obtaining Reservoir Information From Hot Water Wells - Tests That Work and Tests

That Don't Work

The Role of Heat Transfer in the Pressure Build-Up in the Hot Water Wells

Pressure Build-Up and Drawdown Tests in Baca No. 6

Pressure Build-Up Tests on Baca No. 11

Pressure Build-Up Test in Baca No. 13

Pressure Build-Up Analysis, Baca No. 15 
REPORT NO. 40

EXECUTIVE SUMMARY

GEOTHERMAL RESERVOIR EVALUATION

OF THE REDONDO CREEK AREA, NEW MEXICO

FROM A REPORT

Prepared By

J.D. Hartz

UNION GEOTHERMAL DIVISION

UNION OIL COMPANY OF CALIFORNIA

LOS ANGELES, CALIFORNIA

Summary Prepared By

WESTEC SERVICES, INC.

ALBUQUERQUE, NEW MEXICO

JUNE 1980 
ABSTRACT

The purpose of this report was to evaluate the geothermal potential of the Redondo Creek area based on the geologic and reservoir data which existed in November 1976. The findings and conclusions of this report were intended to form the basis for a feasibility study to determine if geothermal energy for electrical generation could be economically extracted. Recommendations are presented for follow-up work needed to establish initial geothermal development and achieve the full potential of the Redondo Creek area and Valles Caldera. The conclusions drawn in this report will change based on more extensive data, and a changing available energy picture. 
The purpose of this report was to evaluate the geothermal potential of the Redondo Creek area based on the then existing geologic and reservoir data. The findings and conclusions of this report were intended to for $m$ the basis for a feasibility study to determine if geothermal energy for electrical generation could be economically extracted. Recommendations are presented for follow-up work needed to establish initial geothermal development and achieve the full potential of the Redondo Creek area and Valles Caldera.

Prior to this report, engineering and geologic studies of the Redondo Creek area wells had indicated the existence of an extensive, high temperature hydrothermal system. Conclusions were derived from the studies completed up to the date of this report. The total amount of water in place in the reservoir was calculated to be on the order of $4.6 \times 10^{12} \mathrm{lbs}$. of hot water. The average reservoir temperature was estimated to be $600 \mathrm{~F}$. From this the estimated potential generating capacity was estimated between 220 and $385 \mathrm{MW}$.

Well interference testing indicated reservoir communication between Baca Wells No. 6, 10, 11, 12, 13 and 14. Well production tests indicated that no measurable reservoir depletion was evident. Total production from the reservoir had been $4935 \times 10^{6}$ lbs. total mass; total injection had been $2340 \times 10^{6}$ bs. resulting in a net withdrawal of $2595 \times 10^{6}$ lbs. total mass. Deliverability of an average well was found to be on the order of $200,000 \mathrm{lbs} / \mathrm{hr}$. total mass with a 35 percent steam fraction.

Further, it was concluded that 16 wells would be required for initial development of a $55 \mathrm{MW}$ generating facility, and that initial development would require drilling 11 additional wells and redrilling 2 wells. Productivity was found to be a result of fracturing in the Bandelier Tuff which is connected to a deeper, more extensive hot water aquifer. The iracture system extent and orientation was indeterminate from the data available at the time of this report. It was concluded that the success of future wells depends on locating fracture permeability. The investigators found no primary or secondary steam cap to be associated with the liquid phase reservoir. An isolated, low-pressure steam zone appeared to exist in the Redondo Creek area, but its extent and size were not determined. No evidence existed to the investigators to prove or disprove active recharge of the hot water reservoir in the Valles Caldera. Scale deposition, primarily calcium carbonate and silica, was decidedly a serious problem which could potentially affect the production facilities, injection facilities, and possibly the reservoir fracture system. 
$\underline{\text { PAGE }}$

Introduction

Conclusions $\quad 2$

Recommendations $\quad 4$

Summary of Geology $\quad 6$

Summary of Drilling Operations 14

Summary of Well Testing $\quad 24$

Chemical Composition, Corrosion and Scale Deposition $\quad 40$

$\begin{array}{ll}\text { Interference Test } & 47\end{array}$

A. Method 47

B. Results 47

1. Production Performance 48

2. Pressure Performance 54

Reservoir Size Estimation $\quad 58$

$\begin{array}{ll}\text { Generating Capacity } & 75\end{array}$

$\begin{array}{ll}\text { References } & 86\end{array}$

$\begin{array}{ll}\text { Figures } & 88\end{array}$

Appendix A: $\quad$ Static Temperature Profiles of the Redondo Creek Area Wells

Appendix B: Mechanical Diagrams of the Redondo Creek Area Wells

Appendix C: $\quad$ Production Performance of the Redondo Creek Area Wells Prior to The Interference Test

Appendix D: $\quad$ Horner Graphs of Pressure Build-Up Tests and Pressure Drawdown Tests

Appendix E: $\quad$ Summary of Chemical Analyses 
TABLE OF CONTENTS OF THE REPORT (Continued)

Appendix F: $\quad$ Production Performance of Wells B-6, 11 and 13 During The Interference Test 10/1/75 Through 4/27/76

Appendix G: $\quad$ Production and Pressure History of The Redondo Creek Area Wells

Appendix H: $\quad$ Static Pressure Profiles, Baca 4, 6, 10, 11, 13 and 15 Comparison of Measured Pressure to Saturation Pressure as Determined From the Measured Temperature in Each Well

40.5 
REPORT NO. 41

EXECUTIVE SUMMARY

BACA WELL NO. 5A

PRESSURE FALLOFF AND IN JECTIVITY

FROM A REPORT

Prepared By

J. D. Hartz

UNION GEOTHERMAL DIVISION

UNION OIL COMPANY OF CALIFORNIA

LOS ANGELES, CALIFOR NIA

JANUARY 1977

Summary Prepared By

WESTEC SER VICES, INC.

ALBUQUERQUE, NEW MEXICO

FEBR UARY 1980 
The study leading to this report was a result of concern as to whether Baca Well No. 5A, a marginally productive well on the Baca Location geothermal reservoir, could be used as an injection well for disposal of geothermal fluids. A short injectivity and pressure falloff test was performed on Baca Well No. 5A during the period of December 20 to 22, 1976. The objectives of the test were to measure injective capacity of the well and determine reservoir and wellbore characteristics. Results of injectivity testing indicate injection capacity to be $2.72 \mathrm{gpm} / \mathrm{psi}$ pressure increase over reservoir pressure. Results of the pressure falloff portion of the test indicate a reservoir of $55218 \mathrm{md}$. $\mathrm{ft} / \mathrm{cp}$ and a skin factor of $\mathbf{- 3 . 5 8 \text { . }}$ The report includes calculations, discussion and graphical summaries of the data and results. The conclusions drawn in the report may have been later modified with the benefit of more recent developments and considerations. 


\subsection{INTRODUCTION AND SCOPE}

During the period of December 20 to 22,1976 , a short injectivity and pressure falloff test was conducted on Baca Well No. 5A. The objectives of the test were to measure injective capacity of the well and determine reservoir and wellbore characteristics. The injectivity test consisted of injecting water into the well for a 24-hour period and measuring the injection pressure. The injection rate varied during the test period but averaged 395 gpm for the entire test. The rate during the injection pressure survey was $417 \mathrm{gpm}$ and this value was used for calculation purposes. The injection rate versus time was plotted for the test period. Total injection during the test period was 570,900 gallons. The injectivity index was calculated from the results of the test. Previous injectivity tests were compared to the one performed for this study.

At the end of the 24-hour injection test a flowing pressure and temperature gradient survey was run. Tools were hung at 5500 feet for about one hour to measure injection pressure and then the well was shut in to measure the pressure falloff. Tools were left at 5500 feet for 6 hours and then pulled from the well. Another survey was run the next day before returning the well to injection. The pressure falloff was then plotted versus dimensionless time.

2.0 SUMMARY AND CONCLUSIONS

To date, 72,852,400 gallons (1.73 MM bbls) of produced fluids have been reinjected in Baca Well No. 5A. The well was completed in the Paliza Canyon Andisite at a depth of 6973 feet. The well was then cased to 2828 feet with 13-3/8 inch pipe, from 2692 feet to 4400 feet with a 9-5/8 inch liner and 8-3/4 inch open hole from 4400 feet to 6973 feet T.D. During drilling of the well fractured zones were noted from 5010 to 5016 feet, 5290 to 5310 feet, 5655 feet, and 6070 to 6075 feet in the open hole portion of the well. An injection profile run in the well on February 12, 1976 indicated about 50 percent of the water was leaving the wellbore in the interval 5550 to 5880 feet. Tools stopped at 5886 feet but it was assumed that the rest of the water was being injected into the Bandelier Tuff between 5880 to 6600 feet.

A subsequent pressure and temperature survey done in June 1976, also stopped at 5865 feet, which indicated possible scale deposition, bridging in the open hole or both. Results of this injectivity test and those done previously indicated that there had been no significant change in the injective capacity though the calculated capacities ranged from 2.46-3.55 gpm/psi. The present test indicated $2.72 \mathrm{gpm} / \mathrm{psi}$ and this was thought to have been the most representative of the injectivity tests done on the well. 
The pressure falloff test was thought to have given some information as to the reservoir characteristics around the wellbore and the mechanical condition of the well, whether or not the well was "damaged". The fluid mobility ratio, $\mathrm{kh} / \mu$, calculated was $55218 \mathrm{md}$. $\mathrm{ft} / \mathrm{cp}$. This value was compared to values determined from pressure build-up tests done on productive wells which ranged from 20,300 to $64,000 \mathrm{md}$. ft/cp. From this the reservoir around Baca No. 5A appeared to have the same fluid mobility characteristics as that of the reservoir rock penetrated by other wells in the same vicinity.

Further conclusions were drawn and discussion made concerning the permeability thickness product $k h$, and its relationship to the entire reservoir versus the close vicinity of this well. Also considered was the skin effect and whether it changed with time. 


\author{
REPORT NO. 42 \\ EXECUTIVE SUMMARY \\ BACA WELL NO. 15 \\ PRODUCTION TEST AND \\ RESERVOIR EVALUATION
}

\author{
FROM A REPORT \\ Prepared By \\ J. D. Hartz \\ UNION GEOTHERMAL DIVISION \\ UNION OIL COMPANY OF CALIFOR NIA \\ LOS A NGELES, CALIFOR NIA \\ MAY 1977
}

\author{
Summary Prepared By \\ WESTEC SER VICES, INC. \\ ALBUQUERQUE, NEW MEXICO \\ FEBRUARY 1980
}




\begin{abstract}
This report presents the results and analyses of data gathered during production and pressure buildup tests conducted on Baca Well No. 15 from October 1976 to April 1977. Production performance, reservoir characteristics and fluid chemistry data are presented and discussed in relation to previous tests and findings in the Redondo Creek area wells. The report includes calculations and extensive discussion and tabular and graphical representations of the data and results. More recent information and discussion may be available in more recent studies.
\end{abstract}




\subsection{INTRODUCTION AND SCOPE}

This report presents the results and analyses of data gathered during production and pressure buildup tests conducted on Baca Well No. 15 from October 1976 to April 1977. Production performance, reservoir characteristics and fluid chemistry data are presented and discussed in relation to previous tests and findings in the Redondo Creek area wells. The well was completed in June 1975 and was used as an observation well until these tests were performed. Initially, the well was cased to 2509 feet with 9-5/8 inch casing and left as an open hole completion from 2509 to 5505 feet. A two-phase flow test done from June 27, 1975 to July 14, 1975, indicated a total mass rate on the order of $170,000 \mathrm{lb} / \mathrm{hr}$. at 65 psig wellhead pressure and a steam fraction estimated at 70 percent.

During the interference test from October 1975 to May 1976, the well was used as an observation well. In September of 1976, the well was recompleted and a 7 inch liner with alternating blank and slotted joints was hung over the interval of 2371 to 5503 feet. A string of 2-3/8 inch tubing was also run in the well from surface to 5472 feet with perforations at $100,1000,2000,3000$, 4000 , and 5000 feet. The tubing was utilized to gather flowing pressure and temperature data during the susequent production test.

2.0 SUMMARY AND CONCLUSIONS

Baca Well No. 15 is completed in a steam cap or steam dominated reservoir, but it also has been found to have access to liquid-phase reservoir. Deliverability of the well had been about $178,000 \mathrm{lb} / \mathrm{hr}$. total mass and $107,000 \mathrm{lb} / \mathrm{hr}$. steam, at a wellhead pressure of $150 \mathrm{psia}$. The steam fraction of the produced fluids at Baca Well No. 15 was much higher, about 61 percent of the total mass, than that of any other well in the Redondo Creek area at the time. The size of the steam cap or reservoir could not be determined from data developed to the date of the report. Geologic and engineering data suggested that the area to the northwest of Baca Well No. 15 should have the potential for tapping additional steam production and that further drilling may help determine its size and reserves.

Analysis of data gathered in the production test of Baca Well No. 15 led to the follewing conclusions.

1. Baca Well No. 15 produced from a steam cap or steam dominated reservoir but it also had productivity from the liquid-phase reservoir. The two production zones appeared to be separated and commingled only within the wellbore, as evidenced by flowing pressure and temperature data.

2. The drainage area of Baca Well No. 15 appeared to be confined or partially confined because of a hydrologic discontinuity separating it from the reservoir penetrated by Baca 4,6,11, and 13 . 
3. Geochemical data suggested that the liquid-phase produced at Baca Well No. 15 came from the same reservoir as the liquid produced at Baca 4, 6, 11, and 13 .

4. Productivity index, determined from flowing pressure surveys, was about $410 \mathrm{lb} / \mathrm{hr} / \mathrm{psi}$ drawdown, about 50 percent greater than the average for other Redondo Creek area wells. Productivity was not restricted by wellbore design.

5. Estimated deliverability of Baca Well No. 15 was about $178,000 \mathrm{lb} / \mathrm{hr}$. total mass and $107,000 \mathrm{lb} / \mathrm{hr}$. steam at a wellhead pressure of 150 psia.

6. Reservoir fracture system (kh) in the Baca Well No. 15 drainage area was at least $5,500 \mathrm{md} / \mathrm{ft}$., which is comparable to the $\mathrm{kh}$ determined in the other Redondo Creek area wells.

7. The static reservoir pressure had not built up to the initial pressure (2347 hours after shut-in) but it was anticipated that it would. Therefore, no pressure depletion was evident.

8. No flow barriers or drainage area boundaries were evident from the pressure buildup data.

9. The size of the steam cap or steam dominated reservoir penetrated by Baca Well No. 15 was indeterminate from the data available. Further drilling and testing would be necesary to establish the reserves and the size of the reservoir or steam cap.

10. Pressure observations at Baca 11 were inconclusive in regard to interference from Baca 15. Pressure disturbances at Baca 11 were probably caused by wellbore boiling and condensation. Any pressure disturbance caused by interference would have been minor compared to the localized pressure fluctuations in Baca 11. Therefore, the wellbore phenomena tend to dominate and mark reservoir disturbances if they occurred. 


\section{TABLE OF CONTENTS OF THE REPORT}

$\underline{\text { PAGE }}$

INTRODUCTION

CONCLUSION

RECOMMENDATIONS

HISTORY

PRODUCTION PERFORMANCE

PRODUCTIVITY

FLOWING PRESSURE MATCHING AND

DELIVERABILITY FORECAST

PRESSURE BUILDUP ANALYSIS

PRESSURE OBSERVATIONS AT BACA 11

FLUID CHEMISTR Y

REFERENCES

FIGURES

APPENDIX A

APPENDIX B 
REPORTS NO. 43 to 48

EXECUTIVE SUMMARY

GEOTHERMAL DEMONSTRATION

POWER PLANT

COMPLETE PROPOSAL

FROM A REPORT

Prepared By

UNION GEOTHERMAL DIVISION

UNION OIL COMPANY OF CALIFORNIA

LOS A NGELES, CALIFOR NIA

AND

PUBLIC SER VICE COMPANY OF NEW MEXICO

ALBUQUERQUE, NEW MEXICO

JANUARY 1978

Summary Prepared By

WESTEC SER VICES, IN C.

ALBUQUERQUE, NEW MEXICO

MARCH 1980 
This proposal was submitted to the U. S. Department of Energy (DOE) in response to a request by DOE for project proposals. DOE issued Program Opportunity Notice EG-77-N-03-1717 in 1977 and the Union Oil Company of California and the Public Service Company of New Mexico (PNM) submitted this proposal to DOE which involves the initial development of the BACA geothermal resource in North-Central New Mexico. The proposal consists of an introductory text and five additional volumes which provide a comprehensive discussion of the technical, legal and economic aspects of the proposed project. The six volumes are entitled: 1) Project Description; 2) Volume I, Project Abstract; 3) Volume Il, Technical and Management Proposal; 4) Volume III, Business Proposal; 5) Volume IV, Cost Proposal; and 6) Volume V, Economics Information. The project for which this proposal was competitively submitted has been funded by DOE as a result of this successful proposal. 
I.0 INTRODUCTION AND SCOPE

The area known as the Valles Caldera was originally confirmed as a geothermal resource by the Baca Land and Cattle Co., the owner of the property. The rights to the geothermal resource were then leased to Union Oil Company of California. Public Service Company of New Mexico and Union Oil Company have joined together to explore the possibility of utilizing the thermal energy in the caldera for generating electricity, and have found that the resource can support the generation of at least $400 \mathrm{MW}$. The initial phase of planned development is a $50 \mathrm{MW}$ demonstration plant, for which this proposal has been written.

The proposal includes background information, a plan for the development of the field to support $50 \mathrm{MW}$ demonstration, a management plan, a proposed assignment of responsibilities, and an extensive analysis of the economics of the project.

The total cost of the proposed project was estimated in the proposal to be slightly in excess of $\$ 100$ million. Of this amount, Union and PNM proposed that DOE contribute as a maximum $\$ 45,435,500$, with Union and PNM assuming a responsibility for the balance of project costs. In addition, a revenue sharing concept was offered which proposed to return to DOE as much as $50 \%$ of DOE's total contributions. The result is that the net project cost to DOE could be as little as half of DOE's initial financial responsibility.

\section{$2.0 \quad$ SUMMARY AND CONCLUSIONS}

The project area is privately owned land in the Redondo Creek area of the property known as Baca Location No. 1, and is located approximately 60 miles north of Albuquerque and 19 miles west of Los Alamos. the Baca Location, in the Jemez Mountains, encompasses the major portion of a large caldera. This is a circular depression, 12 to 15 miles in diameter, which represents the latest stage of a volcanic sequence which began 1.4 million years ago. The most recent volcanic event was about 100,000 years ago. The principal geothermal reservoir discovered to date consists of several trillion pounds of slightly saline hot water. A second steam reservoir has also been encountered, but its extent is unknown at this time.

Eighteen wells have been drilled to date at the Baca location, and of the wells drilled in the Redondo Creek area, 8 are useable as either production or injection wells. An additional 13 to 16 wells will be required for the proposed 50,000 kilowatt demonstration project. The production and injection system will involve handling 3.4 million pounds per hour of hot water and steam. Steam will be separated at a pressure of 125 psig for use in the generating plant and all of the water from the separation process will be returned to the reservoir via injection wells. 
The generating plant will incorporate a single-inlet-pressure turbine generator with a gross output of 50,000 kilowatts. The exhaust steam will be condensed in a closed system to facilitate the handling of noncondensible gases. While the steam contains only trace amounts of hydrogen sulfide, the plants will incorporate a suitable hydrogen sulfide abatement system. The electrical energy generated at the plant will be fed into PNM's existing transmission and distribution network. The cost of the electrical energy supplied from the plant to PNM's existing transmission and distribution network. The cost of the electrical energy supplied from the plant to PNM's customers is expected to be competitive with the cost of power from an alternative coal-fired generating plant.

The organization responsible for construction and operation of the plant and facilities is created ad hoc from the existing organizations of PNM and Union. Union will be responsible for drilling the wells and delivering steam to the generating plant while PNM will own and operate the generating plant and transmission facilities. Executive control of the project is vested in an Operating Committee, which is composed of senior officials from both companies. Reporting to the Operating Committee is a Project Manager, who is presently an employee of PNM. He will be responsible for overseeing the normal daily activities of the project.

The Baca geothermal resource shares common features with a large number of the more important geothermal resources in the western United States. Accordingly, a successful demonstration project at Baca is expected to serve as a strong stimulus to development of geothermal resources for electrical power generation in many years. 


\section{LIST OF VOLUMES IN THE PROPOSAL}

\section{PROJECT DESCRIPTION}

VOLUME I,

VOLUME II,

VOLUME III,

VOLUME IV,

VOLUME V,
PROJECT ABSTRACT

TECHNICAL AND MANAGEMENT PROPOSAL

BUSINESS PROPOSAL

COST PROPOSAL

ECONOMICS INFORMATION 
TABLE OF CONTENTS OF THE PROJECT DESCRIPTION

\begin{tabular}{cl} 
SECTION & \\
\hline 1 & INTRODUCTION \\
2 & SITE LOCATION \\
3 & GEOLOGY OF THE RESERVOIR \\
4 & WELL CHARACTERISTICS \\
5 & FLUID PROCESSING \\
6 & GENERATION OF ELECTRICITY \\
7 & POWER DISTRIBUTION SYSTEM \\
8 & PRODUCTION COST OF ELECTRICITY \\
9 & DATA ACQUISITION AND DISSEMINATION \\
10 & GDPP PROJECT ORGANIZATION AND RESPONSIBILITIES \\
11 & MODELING VALUE
\end{tabular}

$\underline{\text { PAGE }}$ 
TABLE OF CONTENTS OF VOLUME I

PROJECT ABSTRACT

SECTION

PAGE

1

2

3

4

5

6

7

8

9

10

11

12
INTRODUCTION

SITE LOCATION

GEOLOGY OF THE RESERVOIR

WELL CHARACTERISTICS

FLUID PROCESSING

GENERATION OF ELECTRICITY

POWER DISTRIBUTION SYSTEM

PRODUCTION COST OF ELECTRICITY

DATA ACQUISITION AND DISSEMINATION

GDPP PROJECT ORGANIZATION AND RESPONSIBILITIES

FIN A N CIAL COMMITMENT

MODELING VALUE 
TABLE OF CONTENTS OF VOLUME II

TECHNICAL AND MANAGEMENT PROPOSAL

SECTION

PAGE

1 CONVERSION SYSTEM

1.1 New Equipment Development Requirements

1.2 Fluid System

1.2.1 Reservoir Development Plan

1.2.2 Drilling and Testing of Development Wells

1.2.3 Pipelines and Production Facilities

1.2.4 Fluid Injection System

1.2.5 Roads and Surface Construction

1.2.6 Spare and Backup Facilities

1.3 Power Plant

1.3.1 Design Rationale: Binary vs. Flash

1.3.2 Power Plant Design

1.3.3 Water Consumption

1.3.4 Degradation of Transport Studies

1.3.5 Degradation of Fluid Quality

1.3.6 Performance and Reliability Test Plans

1.4 Electrical Distribution

1.4.1 Transmission System Design

1.4.2 Sales Agreement

2 RESER VOIR AND SITE

2.1 Reservoir Capacity

2.2 Reservoir Longevity

2.3 Fluid Disposal

2.4 Reservoir and Fluid Properties

2.5 Regional Setting

2.5.1 Geology

2.5.2 Local Geography

2.6 Ownership and Lease Interests

2.7 Evidence of Resource Potential

2.7.1 Results of Surface Investigations

2.7.2 Results of Drilling

2.7.3 Reservoir Evaluation and Field Development

2.8 Site Information

3 CAPABILITIES OF THE TEAM

3.1 Direct and Related Project Experience

3.2 GDPP Project Organization

3.2.1 Functional Arrangement and Features

3.2.2 DOE Access and Visibility/Reporting

3.2.3 Responsibilities, Line of Communication and Levels of Authority

3.3 Key Personnel

3.3.1 Union Oil Company Personnel

3.3.2 Public Service Company of New Mexico Personnel

3.3.3 Operating Committee 
3.4 Management Plan

3.4.1 Cost Control and Reporting

3.4.2 Schedule Control and Reporting

3.4.3 Performance Control and Reporting

3.4.4 Corrective Action

3.4.5 Configuration Management

3.4.6 Data Management

3.4.7 Purchasing

3.4.8 PNM Subcontractor Selection and Control

3.4.9 DOE Participation

3.4.10 Staffing and Continuity

4 ENVIRONMENTAL INFORMATION

4.1 Description of the Existing Site Environment

4.1.1 Geography and Demography

4.1.2 Land Use

4.1.3 Hydrology

4.1.4 Meteorology and Air Quality

4.1.5 Ecology

4.1.6 Regional Landmarks

4.1.7 Social Profile

4.2 Analysis of Potential Environmental Impact

4.2.1 Physical Environment

4.2.2 Ecological Environment

4.2.3 Socioeconomic Environment

4.2.4 Accidents

4.3 Conflicts with State, Regional Local Land Use Plans and Programs

4.4 Disposal of Wastes

4.5 Effuent and Environmental Measurement and Monitoring Programs

4.5.1 Baseline Monitoring

4.5.2 Operational Monitoring

5 DATA GENERATION AND TECHNOLOGY TRANSFER

5.1 Power Plant Data Monitoring

5.2 Geologic and Geophysical Monitoring

5.3 Subsurface Data Monitoring

5.4 Dissemination of Information

6 PROJECT PLANS
6.1 Permits
6.2 Plant Operation Plan
6.3 Project Schedule
6.4 Security Plans for the GDPP Project Site
6.5 Expansion Plans 


\section{TABLE OF CONTENTS OF VOLUME III BUSINESS PROPOSAL}

SECTION

PAGE

1 FINANCIAL RESPONSIBILITY

1.1 Financial Ability to Support the GDPP Project

1.2 Financial Statements

2 FINANCIAL ARRANGEMENTS AMONG TEAM MEMBERS

2.1 Team Cost Sharing

2.2 Team Revenue Sharing

2.3 Long Term Commitment to Geothermal Production of Electricity

3 CESSATION OF GOVER NMENT PARTICIPATION

4 DISMANTLING AND RESTORATION

5 STATE AND LOCAL SUPPORT

6 LABOR AVAILABILITY

7 IMPACT ON LOCAL ECONOMY

8 SMALL BUSINESS PARTICIPATION 


\section{TABLE OF CONTENTS OF VOLUME IV COST PROPOSAL}

SECTION

1 PROGRAM PLAN

1.1 Wells and Steam Production System (Union)

1.1.1 Environmental Studies and Permits

(WBS Element 1.1.1)

1.2.3 Preproduction Drilling

1.1.3 Field Steam Production and Injection System (WBS Element 1.1.3)

1.1.4 Operation and Maintenance (WBS Element 1.1.4)

1.1.5 Make-up Well Drilling (WBS Element 1.1.5)

1.2 Power Plant and Distribution System (PNM)

1.2.1 Environmental Studies

1.2.2 Power Plant Design and Construction

1.2.3 Distribution System Design and Construction

1.2.4 Plant Operation and Maintenance

(WBM Element 1.2.3)

1.2.5 Project Management

1.3 Data Gathering, Evaluation and Dissemination

(WBS Element 1.3)

2 SUMMARY OF PROJECT COSTS

2.1 Summary and Contractor/DOE Cost Sharing

2.2 Revenue Sharing

3 CONTRACT COST FORMS

4 SUPPORTING SCHEDULES

4.1 Union Oil Company

4.2 Public Service Company of New Mexico 
REPORT NO. 50

EXECUTIVE SUMMARY

HISTORICAL COST DATA

RECONCILIATION OF SUMMARY

SCHEDULES

FROM A REPORT

Prepared By

UNION GEOTHERMAL DIVISION

UNION OIL COMPANY OF CALIFOR NIA

LOS ANGELES, CALIFOR NIA

JULY 1978

Summary Prepared By

WESTEC SER VICES, INC.

ALBUQUERQUE, NEW MEXICO

MARCH 1980 
This report is a compilation of cost summary schedules for Union Oil Company expenditures for development of geothermal resource in the Valles Caldera in North-Central New Mexico. The period covered is from inception to July 1978. Expenditures are itemized as to well completion expenses per well, types of facility, and types of overhead. Costs are broken down on a yearly basis for the time dependent items such as salaries, employee benefits, rent and utilities. No explanatory text is included with the report.
\end{abstract}


REPORT NO. 51

EXECUTIVE SUMMARY

\title{
SOILS IN FORMATION FOR THE
}

PROPOSED BACA GEOTHERMAL PROJECT

\author{
FROM A REPORT \\ - \\ Prepared For \\ Prepared By \\ UNION GEOTHERMAL DIVISION \\ U. S. FOREST SER VICE \\ UNION OIL COMPANY OF CALIFORNIA \\ SANTA FE, NEW MEXICO \\ LOS ANGELES, CALIFOR NIA \\ AND \\ AND \\ PUBLIC SER VICE COMPANY \\ EARTH ENVIRONMENTAL CONSULTANTS \\ OF NEW MEXICO \\ ALBUQUERQUE, NEW MEXICO \\ ALBUQUERQUE, NEW MEXICO \\ 1979
}

Summary Prepared By

WESTEC SER VICES, INC.

ALBUQUERQUE, NEW MEXICO

MARCH 1980 
This report consists of two sections containing soil data and qualitative comments concerning its appearance. The data covers the Santa Fe National Forest adjacent to the southern boundary Baca Location No. 1 properties, and the Bandelier National Monument. Section 1 of the report contains data sheets on 28 mapping units of the Santa Fe National Forest completed by the U. S. Forest Service. These data sheets include climatological, geological, and biological information in addition to the soils data. Section 2 contains 22 mapping units of the Bandelier National Monument. The soils of each unit are discussed individually. No introductory or summary tests are included in Section 1, while Section 2 discusses how the data was formed, and explains the overall geology, climate, and biology in separate sections. Maps are included which display the location of the mapping units.
\end{abstract}


TABLE OF CONTENTS OF SECTION 1

U. S. FOREST SER VICE SOILS INFORMATION

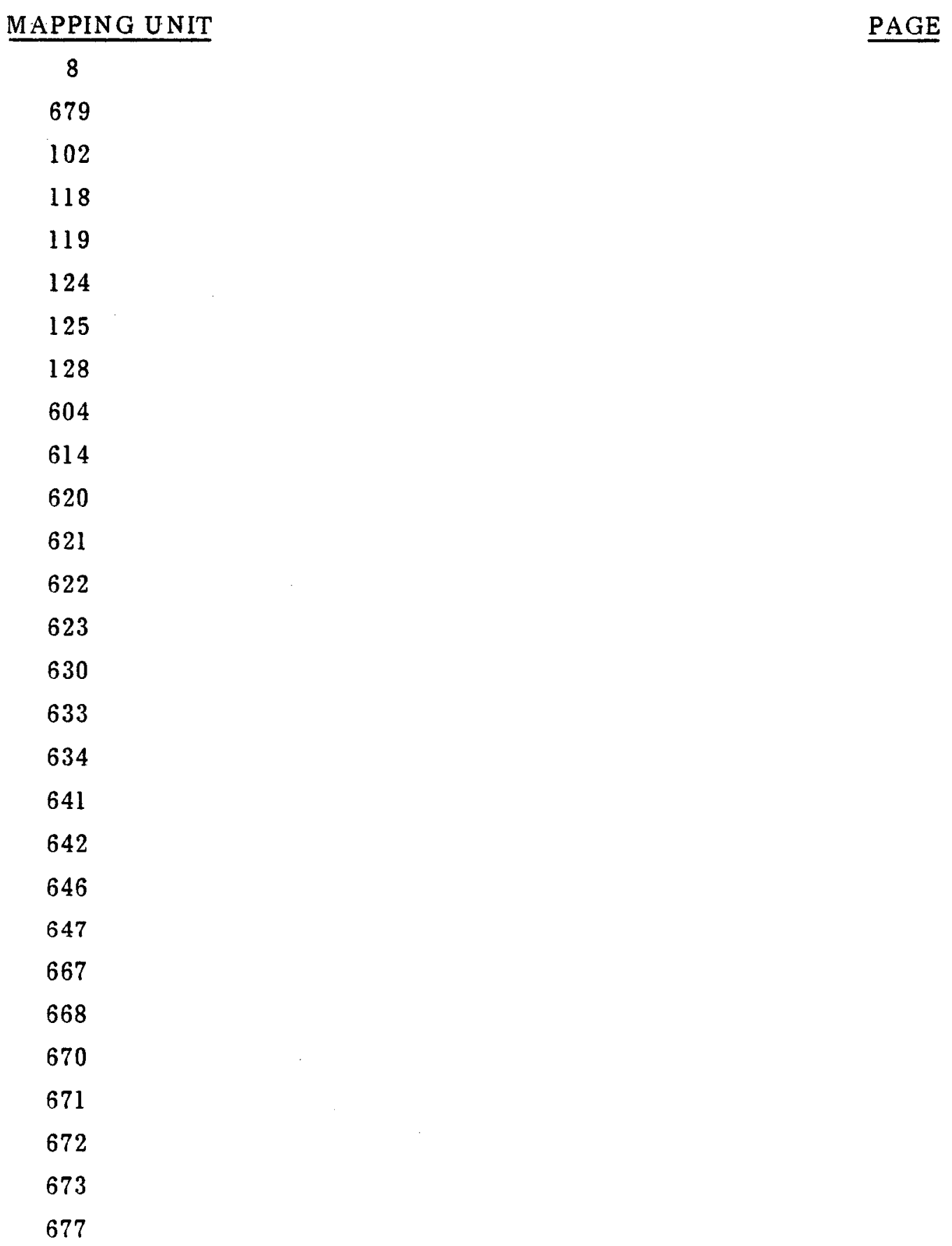


TABLE OF CONTENTS OF SECTION 2

SOIL SURVEY FOR BAN DELIER NATIONAL MONUMENT

$\underline{\text { PAGE }}$

INTRODUCTION

LOCATION AND TOPOGRAPHY

CLIM ATE

GEOLOGY

SOILS

MAPPING UNIT DESCRIPTIONS

Map Unit 1 - Rhyolite Tuff Rock outcrop Hackroy complex

Map Unit 2 - Hackroy Nyjack complex

Map Unit 3 - Frijoles gravelly sandy loam

Map Unit 4 - Rhyolite Tuff Rock outcrop

Map Unit 5 - Very steep Rhyolite Tuff Rock outerop

Map Unit 6 - Typic Ustorthents

Map Unit 7 - Aquic Haplustolls

Map Unit 8 - Basalt Rock outcrop-Prieta complex

Map Unit 9 - Sandstone Rock outcrop

Map Unit 10 - Nyjack loam

Map Unit 11 - Unnaned Eutric Glossoboralfs

Map Unit 12 - Eutric Glossoboralfs complex

Map Unit 13 - Eutric Glossoboralfs Rock outcrop complex

Map Unit 14 - Cumulic Haploboroll-Eutric Glossoboralfs complex

Map Unit 15 - Argic Cryoborolls-Rock outcrop complex 


\section{TABLE OF CONTENTS (CONTINUED)}

Map Unit 16 - Griegos soils

Map Unit BD - Basalt Rock Land

Map Unit BH - Bluewing gravelly sandy loam

Map Unit GL - Guaje gravelly sandy loam

Map Unit LS - Los Alamos-Silver sandy loam

Map Unit PD - Penistaja fine sandy loam

Map Unit TU - Tuff Rock Land

FORMATION OF THE SOILS

Factors of Soil Formation

Parent Material Factor

Climate Factor

Biological Activity Factor

Topography Factor

Time Factor

TRENDS IN SOIL INFORMATION ON BANDELIER NATIONAL MONUMENT

\section{TABLE}

PHYSICAL AND CHEMICAL PROPERTIES OF SOILS FOR TYPICAL PROFILES

MAP

SOILS MAP - BANDELIER NATIONAL MONUMENT 
SAMPLE OF DATA FROM SECTION 1

U. S. FOREST SER VICE SOILS INFORMATION

51.6 


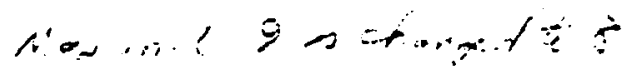

Mapping Unit: 8 -- Entic Haploborolls, Cumulic Haploborolls - complex, $0-15 \%$ slopes

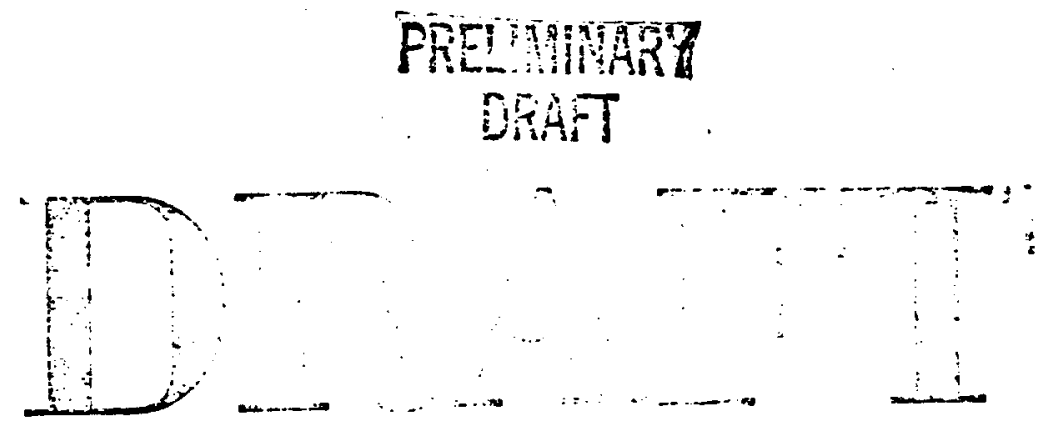

Acres: $\quad 2107$

Landform: Nearly level to gently sloping flood plains and stream terraces. Parent Material: Recent alsuvium from various volcanic rocks.

Slope: 0 to 15 percentgaverage 5 percent.

Elevation: 7,100 feet to 8,000 feet.

Temperature: Mean annual $32^{\circ} \mathrm{F}$ to $47^{\circ} \mathrm{F}$; mean sumer $47^{\circ} \mathrm{F}$.

Precipitation: 20 to 30 inches per year.

Potential Natural Vegetation: Douglas fir-ponderosa pine forest or

ponderosa pine forest.

Existing Vegetation: grass.

\section{Modal Profiles}

\section{Entic Haploborol1}

Typifying Ped最:

0 to 4 inches -- very dark grayish brown (10 $4 / 2,3 / 2)$ loam, very dark brown (10 2/2) moist; soft, very friable, nonsticky, non plastic; about 10 percent coarse fragments; slightly alkaline ( $\mathrm{pH} 7.4$ ). (3 to 5 inches thick) 


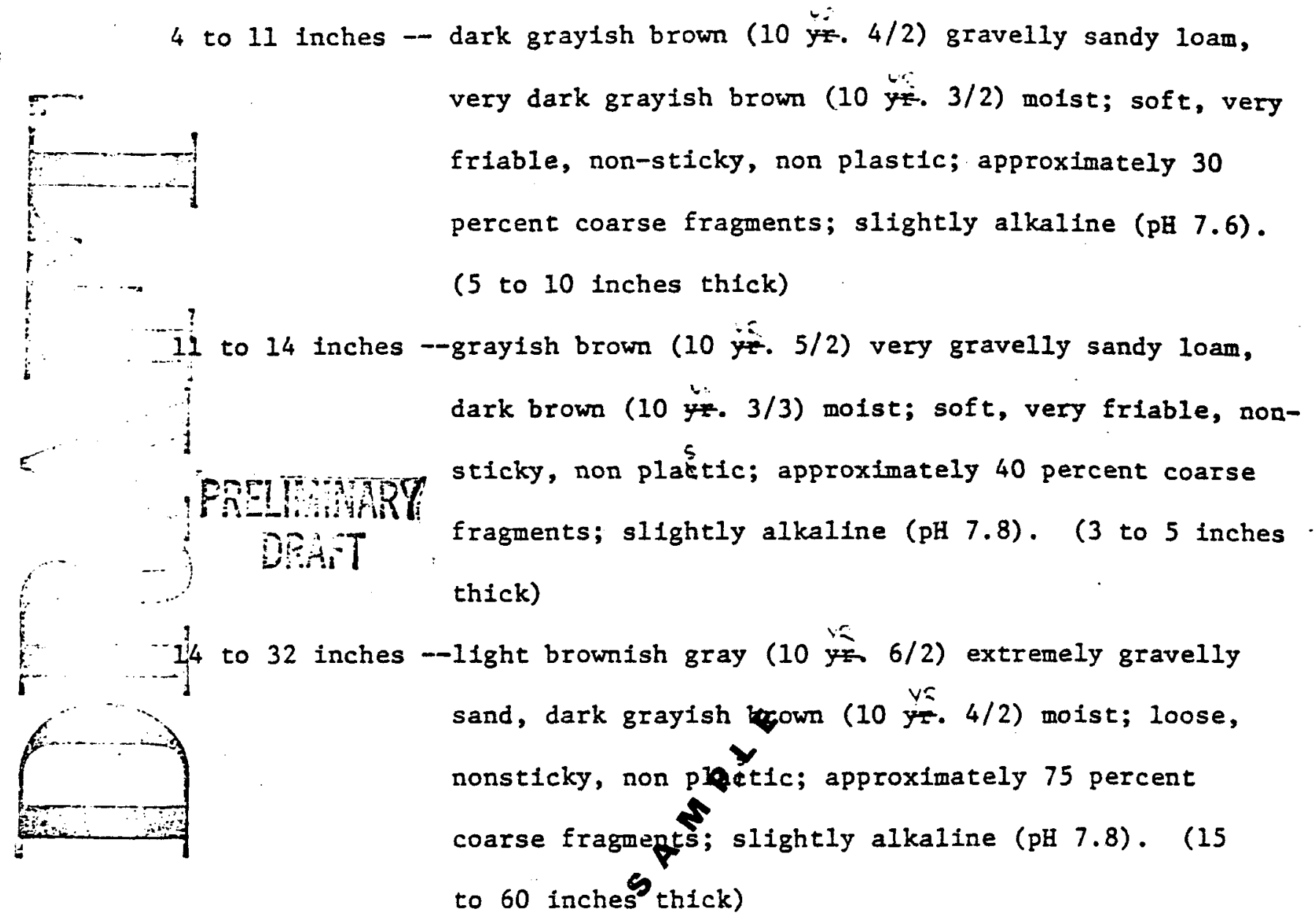

Range in Characteristics: The millic epipedon has hue of $10 \%$ or 7.5 , value of 3 through 5 dry, 2 or 3 moist and chroma of 2 or 3 . It is loam or sandy loam and has 5 to 25 percent coarse fragments. Reaction is neutral to slightly alkaline.

The substratum has hue of $10 \mathrm{yr}$. or $7.5 \mathrm{yr}$., value dry of 5 or 6,3 or 4 moist and chroma of 2 or $3^{\circ}$. It is sand or loamy sand and has 5 to 80 percent coarse fragments. Reaction is slightly alkaline to moderately alkaline and it is calcareous.

Cumulic Haploboroll

Typifying Pedon:

0 to 8 inches - brown (10 $\frac{\text { ys }}{4 / 3}$ ) light clay loam, very dark grayish brown (10 $3 / 2$ ) moist; slightly hard, friable, sliginty sticky, slightly plastic; approximately 5 percent gravel; slightly alkaline ( $\mathrm{pH} 7.4$ ). (2 to 8 inches tnitk) 
REPORT NO. 52

EXECUTIVE SUMMARY

TRANSMISSION SYSTEM

ARCHEOLOGICAL ANALYSIS

FOR THE

PROPOSED BACA GEOTHERMAL PROJECT

FROM A REPORT

Prepared For

UNION GEOTHERMAL DIVISION

UNION OIL COMPANY OF CALIFORNIA

LOS ANGELES, CALIFORNIA

AND

PUBLIC SER VICE COMPANY

OF NEW MEXICO

ALBUQUERQUE, NEW MEXICO
Prepared By

EILEEN CAMILLI

ALBUQUERQUE, NEW MEXICO

1979

Summary Prepared By

WESTEC SERVICES, INC.

ALBUQUERQUE, NEW MEXICO

MAY 1980 


\begin{abstract}
The purpose of the analysis was to predict the presence and extent of archeological resources in the vicinity of the proposed transmission line from the Baca Geothermal Project to Public Service of New Mexico's existing transmission system. Two transmission corridors were proposed as a result of an archival research effort which revealed information on known archaeological sites in the study area.
\end{abstract}


The purpose of this study was to predict the presence and extent of archeological resources in the vicinity of the proposed transmission line from the Baca Geothermal Project to Public Service of New Mexico's (PNM's) existing transmission system, an area of unknown archeological potential. Information gathered during the course of the study also provided baseline data for future cultural resource management.

2.0 METHODS

The study was based on archival research conducted at the Museum of New Mexico Laboratory of Anthropology and agencies such as the U.S. Forest Service and the Bureau of Land Management. From this data an inventory of known prehistoric and historic archeological sites and surveyed areas was compiled. This resulted in the delineation of the study area (sampling universe) comprising approximately 2110 square kilometers located within 14 USGS 7.5 minute quadrangles in northcentral New Mexico. Areas previously surveyed for archeological resources were then used as sample units from which inferences were drawn about the nature and frequency of such resources over the entire study area. The sample units consisted of transects of different lengths varying in width from 10 to 528 feet, quadrants ranging in size from $1 / 16$ section parcels to entire sections, and irregularly shaped areas. To ensure greater accuracy in results, the entire study area was stratified into 15 environmental zones through the use of Landsat imagery, with each zone exhibiting a more uniform distribution of archeological resources than the study area as a whole. Site density figures calculated on the basis of the sample units within each strata were then used to predict the expected frequency of archeological sites in portions of the study area.

3.0 RESULTS

Site inventory results indicated Anasazi sites to be the most common component ( 80.9 percent of total sites inventoried) located at higher elevations within the project area. In general, habitation sites were found to be the most common site type $(60.9$ percent of total sites inventoried). Eighty-two percent of the known Anasazi site types were habitations. Combined limited activity sites comprised 23.5 percent of total sites inventoried. Survey restrictions and investigator and archeological biases which may have skewed the data are discussed by the author.

A 4.3 percent sample of the study area was obtained. Within each zone, the proportion of area sampled varied from 2 to 14 percent. Sampling results indicated a relatively wide range of variation in site density, from 1.19 to 24.26 sites per square kilometer, between sampling strata. Highest site densities were found to occur in Zones 1, 2, and 13. Highest densities for habitation site types were also found to be present in Zones 1,2 , and 13 . 
Location of corridors within specific environmental zones and length of corridor within each zone were the two parameters used in considering the impact of transmission line construction upon the archaeological resources present in the study area. Since the actual routes of the proposed transmission lines were unknown at the time of the study, location and length of corridors were suggested and assessed. Two main routes were considered: 1) a southern route leading from the Baca geothermal plant site to the town of San Ysidro, and 2) an eastern route from the plant site to Station TA-3 near Los Alamos.-

Zones 12 and $10 \mathrm{C}$ are crossed by both the hypothetical southern and eastern corridors. A greater portion of the eastern route would cross Zone 12, while the southern route would extend across greater amount of area in Zone 10C. Comparison of routes on the basis of these two zones alone indicates that the eastern corridor would be less likely to encounter substantial archeological remains at high densities. The remainder of the southern route would be contained in Zones $1,4,7$, and 6. Comparison with the remainder of the eastern route contained in Zones 11, 10A, and $10 \mathrm{~B}$ also indicates that the eastern route would traverse areas expected to have lower site densities. This conclusion only holds, however, if the length of the eastern corridor is kept to a minimum within Zone 10B. 
5. REGIONAL CULTURAL RESOURCE PREDICTIVE STUDY 1

5.1 Research Plan

5.1.1 Objectives

5.1.2 Archival Research

5.1.3 Predictive Research

5.2 Site Inventory

5.2.1 Definition of Study Area

5.2.2 Archival Research Methods

5.3 Predictive Analysis

5.3.1 Sampling Procedure $\quad 20$

5.3.2 The Sample 21

$\begin{array}{ll}\text { 5.3.3 Stratification } & 22\end{array}$

5.3.4 Sampling Results $\quad 34$

5.3.5 Expected Density by Environmental Zone 42

5.4 Proposed Transmission Corridors $\quad 50$

5.4.1 The Southern Route 51

5.4.2 The Eastern Route 52

5.4.3 Comparison of Southern and Eastern Routes 53

$\begin{array}{lll}5.5 & \text { Bibliography } & 54\end{array}$

5.6 Selected References $\quad 63$

$\begin{array}{lll}5.7 & \text { Appendix } & 79\end{array}$ 
REPORT NO. 53

EXECUTIVE SUMMARY

\author{
LAND USE INVENTORY FOR THE \\ PROPOSED BACA GEOTHERMAL PROJECT
}

FROM A REPORT

\author{
Prepared For \\ Prepared By \\ UNION GEOTHERMAL DIVISION \\ WIRTH ASSOCIATES \\ UNION OIL COMPANY OF CALIFORNIA \\ PHOENIX, ARIZONA \\ LOS ANGELES, CALIFORNIA \\ 1979 \\ AND \\ PUBLIC SERVICE COMPANY \\ OF NEW MEXICO \\ ALBUQUERQUE, NEW MEXICO
}

Summary Prepared By

WESTEC SERVICES, Inc.

ALBUQUERQUE, NEW MEXICO

MAY 1980 


\begin{abstract}
The land use inventory prepared by Wirth Associates for Public Service Company of New Mexico (PNM) and Union Geothermal Company of New Mexico (Union) is a portion of the environmental studies conducted for the proposed Baca Geothermal Demonstration Project. The purpose of the report was to provide a data base and land use resource inventory for use in PNM's planning process and the preparation of an environmental impact statement by the U.S. Department of Energy (DOE). In addition, the land use data needs of both Visual Resource Inventory, prepared by the Environmental Affairs Department of PNM, and the socioeconomic analysis, prepared by Mountain West Research Company, are served by this document. The land use study identifies, describes and delineates all significant land use features within the study area in both graphic and narrative form.
\end{abstract}


$1.0 \quad$ INTRODUCTION

The purpose of the study was to inventory all land uses, existing or planned, that could potentially be affected physically or visually by the construction and/or operation of project facilities including the proposed geothermal station cooling towers, well field pipeline system and transmission line. The project area is located in the Jemez Mountains of Sandoval County, New Mexico, approximately 20 miles west of Los Alamos and 60 miles north of Albuquerque. The study area was delineated by analyzing the potential visibility of proposed project facilities in relation to present land uses within the region.

2.0 SCOPE

The land use inventory covers five land use components: 1) Land Ownership, 2) Preservation and Recreation, 3) Existing Land Uses, 4) Planned Land Uses, and 5) Geothermal Resource Development. The study methodology was first described for each component, then each component was inventoried in relation to both the entire study and the station site (project site).

Land Ownership: The entire project site is located within Baca Location No. 1 land grant, which is owned by the Baca Land and Cattle Company. U.S. Forest Service land, with some private inholdings, is adjacent to the west, south and north of Baca, while Los Alamos Ski Club land and Forest Service land are adjacent to the east boundary. National Park Service land lies southeast of the project site. Eight categories of land ownership were identified and mapped during the land use study; these included: 1) U.S. National Park Service (Bandelier National Monument), 2) U.S. Forest Service (Santa Fe National Forest), 3) U.S. Department of Energy (Los Alamos Scientific Laboratory), 4) U.S. General Services Administration, 5) Indian Lands, 6) Los Alamos County, 7) Baca Land and Cattle Company, and 8) private and other.

Preservation: Under the Natural Landmarks Program, National Natural Landmarks are designated "to encourage the preservation of nationally significant properties regardless of ownership.... and to assure the preservation of such a variety of significant natural areas. ..." The Valles Caldera National Natural Landmark is contained in the Federal Register (Volume 43, No. 82, April 27, 1978); the boundaries of the designated site coincide with those of the Baca Location No. 1 land grant.

The Redondo Peak and Redondo Border sites, which are adjacent to the northwest and southeast of the proposed station site location, will be recommended to the U.S. Fish and Wildlife Service for preservation as natural areas with unique ecosystems.

The following Preservational Designations are inventories of park and natural areas which are designated or recognized as unique or undisturbed natural environments. The designations and boundaries vary 
widely in legal status and importance. They include 1) Bandelier National Monument, 2) the RARE II areas of the Santa Fe National Forest, 3) the Monument Canyon Research Natural Area, 4) the Jemez State Monument, and 5) the Recommended State Recreation and Natural Areas. Momument Canyon and Valle Grande have been recommended as State Natural Areas and two fumerole locations were identified as unique geologic features.

Recreation: The Pajarito Ski Area, owned and operated by the Los Alamos Ski Club, Inc., is located west of Los Alamos at the Baca location No. 1 land grant boundary. A relatively large number of recreational resources and facilities exist to the west and southwest of the Baca station site including five National Forest campgrounds, five private or group camps, five day use sites and five points of interest. A few of these sites are located in the canyons along the fishing waters of the Jemez River (including the East Fork) and San Antonio Creek. Most of this area receives very heavy recreational use and is considered by the Forest Service to be an area of high scenic quality. The Forest Service on the National Park Service maintain all hiking and riding trails located in the study area. Fishing is popular along the Jemez River and its tributaries. Redondo Creek, which flows next to the project site, is designated as fishing waters.

Existing Land Uses: Areal and lineal land uses were identified and described, and include the following: 1) the Los Alamos urbanized area, 2) other residential, commercial and/or institutional land uses, 3) Los Alamos Airport, 4) areas closed to unauthorized entry (including the Baca Land and Cattle Company and the Los Alamos Scientific Laboratory), 5) state highways, paved roads, and unpaved, maintained roads, 6) a natural gas pipeline, 7) transmission lines, and 8) others, such as timber, forage and mineral land uses. The project site is located on land owned by the Baca Land and Cattle Company, and the only existing land use which is directly associated with the site is an unpaved and maintained road to the proposed well area. Two major second-home, forest settlements (La Cueva/Horseshoe Spring and Vallecitos de los Indios) are located in the vicinity of the site, while State Highways 4 and 126 and several Forest Routes to the west and south comprise the significant elements of the transportation system near the site.

Planned Land Uses: This section addressed planned uses in both Los Alamos and Sandoval Counties, and focused upon existing and future planning documents for each county as well as the Los Alamos Scientific Laboratory and the Santa Fe National Forest. The only planned land use directly associated with the proposed site, the paving of the well field road, FR-268 realignment, is a part of the proposed project facilities. Two subdivided areas of private land within the National Forest are expected to further expand. These are Cueva/Horseshoe Springs and Vallecitos de los Indios. In addition, the Cerro Pelado area is expected to develop in about five years, Thompson Ridge is presently 
being developed, and the Primos Hermanos area is currently partially developed.

Geothermal Resource Development: The Baca KGRA covers a total of 51,571 acres (approximately two-thirds of the study area). The proposed project site is situated within this resource area with project facilities proposed near the center of the existing major steam well area. Several natural hot springs are located to the west of the site. The federal government has issued competitive leases for goethermal exploration to the west and south of the site.

\subsection{CONCLUSION}

This report focused upon an identification of existing and planned land uses. No analyses of potential land use conflicts were included and no alternatives were suggested. 
List of Figures

INTRODUCTION 1

Overview 1

Project Personnel 1

METHODOLOGY

Study Area

Land Ownership 3

Preservation and Recreation 4

Existing Land Uses

Planned Land Uses

Geothermal Resource Development $\quad 7$

Data Collection and Agency Contacts $\quad 7$

Data Compilation $\quad 8$

INVENTORY

Study Area

Land Ownership 9

Preservation and Recreation 13

Existing Land Uses $\quad 28$

Planned Land Uses 33

Geothermal Resource Development $\quad 34$

Station Site $\quad 37$

Land Ownership $\quad 37$

Preservation and Recreation $\quad 38$

Existing Land Uses $\quad 38$

Planned Land Uses $\quad 38$

Geothermal Resource Development 38

$\begin{array}{ll}\text { REFERENCES } & 39\end{array}$

AGENCY CONTACTS

LIST OF FIGURES

NUMBER

TITLE

$1 \quad$ Land Ownership

Preservation and Recreation provided on

$3 \quad$ Existing Land Uses

tached maps)

$4 \quad$ Planned Land Uses

$5 \quad$ Geothermal Resource Development 


\section{TABLE OF CONTENTS OF THE REPORT (Continued)}

\section{LIST OF TABLES}

NUMBER

TITLE

PAGE

1

Forest Service Recreation Sites

27

2 Recreation Use Information - Santa Fe National Forest

3

LASL Technical Areas

36

39 
REPORT NO. 54

EXECUTIVE SUMMARY

SOILS INVENTORY FOR THE

PROPOSED BACA GEOTHERMAL PROJECT

FROM A REPORT

\author{
Prepared For \\ Prepared By \\ UNION GEOTHERMAL DIVISION \\ UNION OIL COMPANY OF CALIFOR NIA \\ L. A. DAUGHERTY, Ph.D. \\ B. A. BUChanAN, Ph.D. \\ LOS ANGELES, CALIFOR NIA \\ LAS CRUCES, NEW MEXICO \\ AND \\ 1979 \\ PUBLIC SERVICE COMPANY \\ OF NEW MEXICO \\ ALBUQUERQUE, NEW MEXICO
}

Summary Prepared By

WESTEC SER VICES, INC.

ALBUQUERQUE, NEW MEXICO

MARCH 1980 
The intent of this report was to prepare soils information that could be used in assessing the impact of the construction of an electric transmission line from the site of the proposed $50 \mathrm{MW}$ Geothermal Demonstration Project to the Los Alamos, New Mexico electrical grid. Much of the information in this report was provided by the soil conservation service of the United States Drug Administration (USDA) and from a soil survey report of Los Alamos County. The report includes a detailed account of the methods used in analyzing and classifying the soil types of the 16 mapping units surveyed. Each mapping unit is individually. discussed and maps are included for reference.

The information in this report may have been augmented by subsequent studies. 
1.0 INTRODUCTION AND SCOPE

The survey objective was to prepare soils information (maps and descriptions) that could be used in assessing the impact of putting in an electric transmission line. The soil survey maps of the Baca are provided at an order 3 level. The soil survey of the Los Alamos portion of the transmission line is at an order 2 level and is attached as an appendix. The order 3 maps of the Baca are attached to the report and are at a scale of $1: 31,680$. The soils of the order 3 map were identified by transecting, traversing and some observations. Boundaries were plotted by observation and interpretation of remotely sensed data and verified with some observations. The types of map units were mainly associations. The map unit components were mainly phases of soil series and phases of soil families. USDA-SCS Agriculture Handbook 436 was used for definition of the soil families (Soil Taxonomy).

2.0 SUMMARY AND CONCLUSIONS

A survey of this type is intended as a tool for planning purposes and is not site specific in that it includes the area from which the site is to be selected. In many instances, on-site investigations were required for intensive study. The estimates given for the types of soils, amounts of inclusions, and extent of each mapping unit may vary by 20 or more percent. The limitations of the order 3 map were considered before intense or detailed planning was intiated. The conclusions of this report are in the form of the area classification and analysis data to be used in the selection of the transmission line siting. 


\section{TABLE OF CONTENTS OF THE REPORT}

PAGE

Introduction

How This Survey was Made

Mapping Units

Interpretations

Table 1

Table 2

Mapping Unit Interpretations

Photo 1

Photo 2

Photo 3

Photo 4

Appendix 1

Appendix 2 
ENVELOPE

Soils

Slope

Erosion

Depth

Stability

Drainage

Corrosivity

Runoff

Topsoil

General Sensivity 


\author{
REPORT NO. 55 \\ EXECUTIVE SUMMARY \\ STATION AND WELL SITE \\ ARCHEOLOGICAL ANALYSIS \\ FOR THE \\ PROPOSED BACA GEOTHERMAL PROJECT
}

FROM A REPORT

\author{
Prepared For \\ Prepared By \\ UNION GEOTHERMAL DIVISION \\ THE OFFICE OF CONTRACT ARCHEOLOGY \\ UNION OIL COMPANY OF CALIFORNIA \\ UNIVERSITY OF NEW MEXICO \\ LOS ANGELES, CALIFORNIA \\ ALBUQUERQUE, NEW MEXICO \\ AND \\ 1979 \\ PUBLIC SERVICE COMPANY \\ OF NEW MEXICO \\ ALBUQUERQUE, NEW MEXICO
}

Summary Prepared By

WESTEC SERVICES, INC.

ALBUQUERQUE, NEW MEXICO

MAY 1980 


\section{ABSTRACT}

The purpose of the report was to present the results of an areal survey intended to comprehensively examine the archeological resources within the Baca Location No. 1 study area. The report also assessed the possible adverse effects of construction of a proposed geothermal power plant and associated wells. Results indicated one alternative and additional recommendations to the proposed development. 
The report presented the results of an areal survey conducted by the University of New Mexico Office of Contract Archaeology for Public Service Company of New Mexico (PNM) and Union Oil Company of California (Union Oil). The purpose of the survey was to provide a comprehensive examination of the archeological resources of the area, and to assess the possible adverse effects of construction of a proposed geothermal power plant and associated well pads. The report provided baseline data for an environmental assessment to be submitted to the Department of Energy (DOE) by PNM and Union Oil.

\subsection{SURVEY METHODS}

The survey was conducted between July 20 and August 11, 1978 by a field crew of 3 persons temporarily augmented by 2 others. The study area consisted of 1984 acres located in the privately owned Baca Location No. 1 Land Grant. Survey of the study area involved the location of the borders of the tract as guides to the initial transect lines. A series of transects was then walked, the lowermost person flagging the transect, while the uppermost person recovered flags from the previous transect. The spacing interval was about 20 meters, allowing visual coverage of the entire transect. Slopes of $\mathbf{9 0}$ percent or more were not surveyed due to the difficulty involved, and because it was determined that any surface manifestations would not be in situ, but would probably have been moved downslope. The valley bottom below the steep valley side slopes was transected and all drainages were investigated.

Archeological site parameters were defined and flagged with orange tape. Site locations were plotted onto a USGS 7.5 minute topographic map, which occasionally proved difficult given the heavily forested nature of the area. Site areas were closely examined and artifacts were marked with orange pin flags for mapping and photographing. Stakes displaying site numbers were placed near the centers of the sites. Standard Office of Contract Archeology site forms and site provenience, lithic, and historic artifact forms were completed, and sites were sketch mapped. The mapping procedure included plotting the contour of the area, and placing the artifacts on the map in locations derived from their relationship with those contours thereby indicating the internal structure of each site and the spatial relationship between artifact distribution and topography. All measurements used in mapping were paced. Lithic artifacts were coded by artifact type and basic flake morphology and indicated on the site map. Information on site setting, vegetation, artifactual assemblage, and construction (where applicable) was included. A black-and-white photograph or color slide was taken of each site. No artifacts were collected; scale drawings of significant artifacts were made and mapped in place. In many cases, all lithic artifacts present on sites were recorded. When this was not possible a sample was taken, generally consisting of one or more concentration areas defined by extensive reconnaissance of the site area. In 
most cases, artifacts located on roads were not monitored. All notes, photographs, maps, and data forms were placed on file at the Office of Contract Archeology and copies were sent to Mr. Charles Carroll of PNM.

\subsection{RESULTS AND CONCLUSIONS}

Twenty-nine archeological sites were located during the course of the survey. Of that number, 25 contained prehistoric components and 8 contained historic components.

With regard to prehistoric occupation of the study area there appears to have been five base camp locations in the valley, with a series of probable specialized activity sites related to them. The major base camps are located in areas allowing not only the exploitation of a range of habitat zones, but also of more than one valley. The minor base camps are in locations allowing exploitation of a range of habitat zones only. Site location choice appears to have been based upon the most productive floral habitat available, but also appears to have been responsive to localized habitat diversity. The main period of utilization of the canyon is hypothesized to have been during the late summer, based on the floral exploitation values for the various parts of the summer season.

The historic components comprise 8 sites, 1 locality, and 121 aspens with inscriptions on them. The historic sites consist of an isolated cabin, a cluster of cabin sites, a multicomponent site containing an historic trash scatter and an occupied ranch, and a multicomponent site containing a scatter of historic trash.

\section{RECOMMENDATIONS}

If it is determined that there is no prudent and feasible alternative to land altering activities affecting the identified and potential cultural resources in the study area, a program of investigation to mitigative adverse effects will be necessary. Three alternative strategies for mitigation exist: 1) intensive study of a sample of the documented resources prior to any further land altering activities. 2) A combination of investigation of sites known to fall within areas for which surface alteration is planned, avoidance of sites which fall outside such areas and archeological monitoring of construction in areas which have suffered no prior disturbance, and, therefore may contain occluded sites. 3) No action. The second alternative is preferred.

A clearance for land altering activities by the Baca Geothermal Project must proceed on a site-by-site basis. In all cases, avoidance should be considered the preferred alternative. Where avoidance appears to be a feasible alternative but land altering activities are projected for the immediate vicinity of a documented site, the avoidance procedure may be enhanced by fencing the site perimeter. If land altering activities 
are projected for areas in which sites have not been documented but which have not been previously disturbed, a competent archeologist should be present as a monitor during construction activities. If subsurface remains are encountered, construction should cease and the appropriate authorities should be notified. In keeping with these recommendations, activities should be confined to existing roads (which are numerous in the survey area) in so far as possible. Improvements on existing roads will have to take into account the existence of documented resources.

If these recommendations are complied with, clearance is recommended. The religious significance of the area will have to be carefully considered in all future plans and possible nomination to the National Register of Historic Places should be given thoughtful attention. 
1. INTRODUCTION

James L. Moore

2. CULTURE HISTORY

Gale M. McPherson

3. SITE AND LOCALITY DESCRIPTIONS

J.L. Moore, B.J. Vierra, M.E. Harlan

4. THE PHYSICAL ENVIRONMENT

James L. Moore

5. THE ARCHEOLOGY OF THE BACA GEOTHERMAL PROJECT James L. Moore

6. LITHIC ANALYSIS

Bradley J. Vierra

7. A SUGGESTED RESEARCH DESIGN FOR FURTHER INVESTIGATIONS IN THE JEMEZ MOUNTAINS James L. Moore

8. RECOMMENDATIONS

Mark E. Harlan

APPENDIX NO. 1: Master Maps

APPENDIX NO. 2: Artifact Ilustrations

APPENDIX NO. 3: Isolated Occurrences

BIBLIOGRAPHY 
1. Comparison of Pecos Classification and Wendorf

2. OCA:BG:25

3. OCA:BG:28

4. Geological Map of the Study Area

5. Tectonic Map of the Middle Rio Grande

6. Soil Association \# 114

7. Floral Species List

$72-73$

8. Plants of the Area and Their Habitats

84-85

9. Habitat Map with Prehistoric Components Plotted

$87-88$

10. Floral Exploitation Values

11. Availability of Edible Plants

12. Lithic Attributes

100

13. Core and Debitage Attributes

101

14. Lithic Field Form

103

15. Small Site Frequency Counts

$107-108$

16. Small Sites, Total Intersite Percentages

109

17. Small Site Material Type Frequency Counts

18. Large Site Frequency Counts

19. Large Site, Total Intersite Percentages

20. Large Site Material Type Frequency Counts

21. Large Site Material Types, Total Intersite Percentages

22. Large Sites, Total Intersite Percentages

23. Cochiti Reservoir Comparative Data

24. Cochiti Reservoir Comparative Data, Intersite Percentages 


\begin{abstract}
REPORT NO. 56
EXECUTIVE SUMMARY

STREAM ECOLOGY INVENTORY FOR THE

PROPOSED BACA GEOTHERMAL PROJECT
\end{abstract}

FROM A REPORT

Prepared for

UNION GEOTHERMAL DIVISION

UNION OIL COMPANY OF CALIFOR NIA

LOS A NGELES, CALIFOR NIA

AND

PUBLIC SERVICE COMPANY

OF NEW MEXICO

ALBUQUERQUE, NEW MEXICO
Prepared by

WHITFORD ECOLOGICAL CONSULTANTS

LAS CRUCES, NEW MEXICO

1979

Summary Prepared by

WESTEC SER VICES, INC.

ALBUQUERQUE, NEW MEXICO

MAY 1980 


\begin{abstract}
A study of the Redondo Creek and Sulfur Creek stream system was conducted to provide a description of the biological and physical characteristics of the streams. The streams were divided into fourteen sections for descriptive purposes. The streams have a great deal of heterogeneity along their entire lengths. The higher wooded sections of the streams were characterized by steep flows and a high percentage of rubble and boulders in the stream, and thus were quite different from the rest of the streams. Below the wooded section, the pattern of communities depended on relative flow rates and the fineness of the bottom type. The $\mathrm{pH}$ levels on most of the streams ranged near 7.0, although, Sulfur Creek was quite acidic ( $\mathrm{pH}$ of 3.75). Other physical characteristics were adequate to support fish and other aquatic organisms. A wide variety of algal and invertebrate taxa were found during the study. Development of the geothermal resources could present water quality concerns due to erosion which would produce increased turbidity of the waters.
\end{abstract}


A study of the Redondo Creek and Sulfur Creek stream system was conducted during the summer of 1978 in order to provide a description of the biological and physical characteristics of the streams. These data were collected in order to provide baseline information from which to predict environmental impact resulting from development of a geothermal electrical generation plant within the watershed of the stream.

The streams were walked and described as to vegetative cover and species composition, bottom composition, depth, presence of pools and obstructions, and flow rate. Physical characteristics of the waters were assessed. These physical characteristics included temperature, $\mathrm{pH}$, total hardness, dissolved-oxygen concentration and transmittance. Algae was sampled at eight locations along the stream. Aquatic animals were sampled using a Surber sampler.

2.0 SUMMARY AND CONCLUSIONS

The streams were divided into fourteen sections for descriptive purposes. Brief descriptions of these fourteen sections are listed below in sequence of highest to lowest in elevations:

1) Marsh Wood: This section included the source spring of Redondo Creek and $336 \mathrm{~m}$ of the stream flowing through coniferous forests and open marshy areas.

2) Drywood: This section of Redondo Creek included a marshy area which flowed into a wooded area containing Douglas and white fir, blue spruce, aspen, and some maples. The section stopped at a small dam.

3) Alder Meadow: This section of Redondo Creek was approximately 2.5 $\mathrm{km}$ long and flowed through dry meadows with alder thickets of Redondo Creek.

4) Gambel Oak Gully: This section of Redondo Creek was approximately $1.1 \mathrm{~km}$ long and flowed through a gully with densely wooded slopes containing pines and oaks.

5) Pine-Alder Slope: Redondo Creek flowed through a densely vegetated area containing pine and alder.

6) Darnell Ranch Meadow: This section of Redondo Creek flowed through a somewhat disturbed meadow area.

7) Narrow Wet Meadow: This section of Redondo Creek flowed through a somewhat disturbed meadow area.

8) Pine Meadow: This section of Redondo Creek flowed through an area shaded by large pines on slopes adjacent to the stream.

9) Open Dry Meadow: This section of Redondo Creek ran through a dry meadow containing scattered Ponderosa Pine. 
10) Marsh: The marsh area was found near the confluence of Redondo and Sulfur Creeks.

11) Pine-Alder Gully: This section of Sulfur Creek ran through a rocky slope bordered by pine and alder. Several small waterfalls were present.

12) Alder-Pine Meadow: This section of Sulfur Creek flowed through an open pine meadow.

13) River Valley: This section of Sulfur Creek flowed through a valley containing homes, pastures, and camping grounds.

14) River Canyon: Sulfur Creek flowed through a narrow canyon prior to its confluence with the Jemez River.

The source of Redondo Creek maintained a constant temperature of $11^{\circ} \mathrm{C}$. The water temperatures of the remainder of the streams were directly proportional to air temperature. The $\mathrm{pH}$ at the source of Redondo Creek was 6.85 , and the $\mathrm{pH}$ of the downstream portion of the creek ranged near 7.0. Sulfur Creek, before its confluence with Redondo Creek, was acidic ( $\mathrm{pH}$ of 3.75). After Sulfur Creek's confluence with Redondo Creek, $\mathrm{pH}$ ranged up to 7.5 indicating a buffering action by Redondo Creek waters. Hardness of the creek waters ranged between 20 to $35 \mathrm{ppm}$ of $\mathrm{CaCO}_{3}$. Dissolved-oxygen concentrations ranged from 6.0 to $8.1 \mathrm{ppm}$. All waters were clear and lacking in turbidity. All chemical parameters (with the exception of $\mathrm{pH}$ of the Sulfur Creek waters were acceptable to most aquatic organisms).

Thirteen taxa of diatoms, three taxa of filamentous algae and one filamentous chrysophytan taxa were found during algae surveys. In only a few areas along the streams were algae macroscopically visible.

Eighty-one taxa of animals were found during aquatic samplings. These taxa included 6 mite taxa, 10 beetles, 17 nonmidge diptera, 12 midge taxa, 6 magflies, a semi-aquatic bug, 2 odonata, 6 stoneflies, 18 caddisflies and 5 mollusea.

The streams appear able to support a fish population, although only a few sculpins were found during the survey. Downstream barriers may affect upstream fish migration.

The probable effects of the geothermal development on the streams (other than geothermal water leakage) would be silting caused by exposed-topsoil runoff and water removal. Both these factors would alter the nature of the streams. The long-term effect of such perturbations would depend upon the streams' self-cleaning properties, which are functions of its flow rate and proximity to other streams which would serve animal recolonization. Unless the marginal vegetation is damaged, there should be little effect on the heterotrophic food base of the streams. 
3. Biota of Redondo Creek

3.1 Study Area

3.2 Methods

3.2.1 Chemical Characteristics of the Stream

3.2.2 Algae

3.2.3 Animals

3.3 Stream Sections

3.3.1 Marsh Wood

3.3.2 Dry Wood

3.3.3 Alder Meadow

3.3.4 Gambel Oak Gully

3.3.5 Pine-Alder Slope

3.3.6 Darnell Ranch Meadow

3.3.7 Narrow Wet Meadow

3.3.8 Pine Meadow

3.3.9 Open Dry Meadow

3.3.10 Marsh

3.3.11 Pine-Alder Gully

3.3.12 Alder-Pine Meadows

3.3.13 River Valleys

3.3.14 River Canyon 
3.4 Physical Characteristics

3.4.1 Water Temperature and Chemistry

3.4.2 Algae of Redondo and Sulphur Creeks

3.4.3 Animal Distributions

3.5 Bibliography 
REPORT NO. 57

EXECUTIVE SUMMARY

VISUAL RESOURCE INVENTORY FOR THE

PROPOSED BACA GEOTHERMAL PROJECT

FROM A REPORT

J. M. Cantu

EN VIRONMENTAL AFFAIRS DEPARTMENT

PUBLIC SERVICE COMPANY

OF NEW MEXICO

ALBUQUERQUE, NEW MEXICO

1979

Summary Prepared By

WESTEC SER VICES, INC.

ALBUQUERQUE, NEW MEXICO

MAY 1980 


\begin{abstract}
A visual resource inventory was prepared by the Environmental Affairs Department of Public Service Company of New Mexico (PNM) to document visual resources in the vicinity of the proposed 50MW Geothermal Demonstration project at Baca Location No. 1 . The purpose of the inventory was to identify areas and degrees of visual quality and interest for use in furthering PNM's planning process and in preparation of the susequent Environmental Impact Report to be filed by the Department of Energy (DOE). A land use inventory prepared by Wirth Associates provided the data base for references to area land use.
\end{abstract}




\section{$1.0 \quad$ INTRODUCTION}

Because of the importance of visual senses, aesthetics are closely related to other human interest values. Public enjoyment of recreational, historic and cultural resources are enhanced by visual quality, therefore, the greater the degree of visual quality present in an area, the greater the need for careful planning. By identifying and ranking the visual resources of an area, visual quality becomes manageable, greatly improving the planning process. The Baca inventory is specifically directed toward facilitating visual evaluation of the proposed project, which includes selection and analysis of the transmission system and analysis of the well field and generation facilities.

\section{$2.0 \quad$ SCOPE}

The visual resource inventory is divided into four major sections: 1) Methodology; 2) Baca Analysis; 3) Baca Inventory: and 4) Glossary, Abbreviations/Acronyms and Bibliography.

Methodology: The technique used in analyzing the Baca study area (the study area described in the land use inventory prepared by Wirth Associates) is based on the Visual Management System (VMS) developed by the Forest Service. The data base consisted of USGS 7.5 minute topographic maps, aerial photography, helicopter flights and/or ground confirmation. Definitions of character type, variety classes, sensitivity levels and visual quality objectives were discussed at length.

Category levels used in analyzing the Baca study area characteristics are defined as follows:

Category 1 (Preservation):

Category 2 (Retention):

Category 3 (Partial Retention):

Category 4 (Modification):

Category 5 (Maximum Modification):
Allows natural ecologic changes only.

Provides for management activities which are not usually evident.

Allows activities which remain visually subordinate to the characteristic landscape.

Allows activities which may visually dominate the original characteristic landscape, but must borrow from natural form, line, color or texture.

Permits management activities of vegetative and land form alteration which may dominate the characteristic landscape. 
Baca Analysis: This analysis included a geomorphological analysis of the Baca study area. The Baca study area is described to center on the Valles Caldera in the Jemez Mountains, and is one of the world's largest calderas. A Variety Classification Matrix had previously been established by the Santa Fe National Forest for the San Juan Section of the southern Rocky Mountain Province, which includes the study area. Primary, secondary and tertiary travel routes and use areas within the study area were defined by the Forest Service and used in the inventory. The matrix was used as the basis for determining variety classes.

Baca Inventory: The analysis summarized the sensitivity levels of the Baca study area visual resources by categorizing the resources into the previously described category levels. These levels suggest the amount of alteration permissible within a given area.

\section{Baca Preservation Areas}

1) Bandelier National Monument wilderness area (NPS).

2) Caballo roadless area (FS).

3) Dome roadless area (FS).

4) Monument Canyon Natural Research area (FS).

Baca Retention Areas

1) Canon de San Diego.

2) East fork of the Jemez River.

3) Redondo Peak.

4) Shell Mountain.

5) Cerro Grande.

6) The foreground and some middleground views from some roads and use areas; these include portions of State Highway 4 (NM-4), FR-280, FR-268, East Jemez Road, FR-132, FR-133, FR-289, FR-1. These also include Pajarito Ski Area, Camp May, and Quemazon and Guaje Canyon trails.

7) Middleground views of Los Alamos Canyon.

8) The two forested knolls in the Valle Grande.

Baca Partial Retention Areas

1) All but one valley of the Valles Caldera: Valle Grande, Valle de los Posos, Valle Jaramillo, Valle Santa Rose and Valle Seco. 
2) Forested slopes within the caldera and on the mountainous ring surrounding it which fall within middleground range.

3) The mixed conifer slopes along $\mathrm{NM}-4, \mathrm{NM}-126$, and the Pipeline Road that are generally within viewing range of $\mathrm{NM}-4, \mathrm{NM}-126$, the Pipeline Road, and FRs 106, 10, 280, 268, 286 and 376.

4) Three development areas west of the Baca: La Cueva, Horseshoe Springs and Thompson Ridge.

5) Canyon routes: FR-1 06, unofficial routes along Water Canyon, Canon de Valle, and Los Alamos Canyon on the eastern slope of Sierra de los Valles.

6) Middleground views of the eastern slopes of Sierra de los Valles.

7) Community of Los Alamos and surrounding roads.

Baca Modification Areas

1) The forested domes within the Baca: San Antonio Mountain, Dead Indian, Cerro San Luis, Cerro Santa Rosa, Cerros del Abrigo, and Cerro del Medio.

2) Forested slopes of Redondo Border and Redondo Peak, seldom seen and invisible areas south of $\mathrm{NM}-4$, headwaters of Frijoles Canyon, seldom seen eastern slopes of the Sierra de los Valles, and the background logged areas on Cerro Toledo, Turkey Ridge, and Cerro de los Posos.

3) Restricted entry areas of LASL.

Baca Maximum Modification Areas

1) Many logged areas which occur on the Baca.

2) Mesa tops.

3.0 SUMMARY

The visual resource inventory identified, described and ultimately placed into sensitivity levels the visual resources of the Baca study area. No conclusions, recommendations, or alternatives were described. 
List of Figures

List of Tables

INTRODUCTION

4. Visual Resources

4.1 Methodology
4.1.1
4.1 .2
Character Type
4.1 .3
Variety Classes
4.1 .4
Sensitivity Levels
Visual Quality Objectives

4.2 Baca Analysis

4.2.1 Baca Character Type

4.2.2 Baca Variety Classes

4.2.3 Baca Sensitivity Levels

4.2.4 Baca Visual Quality Objectives

4.3 Baca Inventory

4.3.1

Baca Preservation Area

4.3 .2

Baca Retention Areas

4.3 .3

Baca Partial Retention Areas

4.3 .4

Baca Modification Areas

4.3 .5

Baca Maximum Modification Areas

4.4 Glossary

4.5 Abbreviations/Acronyms

4.6 Bibliography 
REPORT NO. 58

EXECUTIVE SUMMARY

BIOTIC INVENTORY FOR THE

PROPOSED BACA GEOTHERMAL PROJECT

FROM A REPORT

Prepared For

UNION GEOTHERMAL DIVISION

UNION OIL COMPANY OF CALIFORNIA

LOS ANGELES, CALIFORNIA

AND

PUBLIC SERVICE COMPANY

OF NEW MEXICO

ALBUQUERQUE, NEW MEXICO
Prepared By

W.R. PILZ AND D.G. SABO

ENVIRONMENTAL AFFAIRS DEPARTMENT

PUBLIC SERVICE COMPANY

OF NEW MEXICO AND BY

W.L. WAGNER

MISSOURI BOTANICAL GARDEN

ST. LOUIS, MISSOURI

1979

Summary Prepared By

WESTEC SERVICES, INC.

ALBUQUERQUE, NEW MEXICO

MAY 1980 


\begin{abstract}
Vegetation and wildlife surveys were conducted within a 22-mile long by 2-mile wide corridor to develop baseline information to assess biological impacts of construction of a geothermal electrical power plant and an electrical transmission line. Nine vegetation habitats were identified during the study. Six species of small mammals and 109 species of birds were recorded during the survey. No threatened or endangered species were found during the survey. However, there is potential that the Jemez Mountain salamander and blue gramma cactus could be found along the alignment.
\end{abstract}


Vegetation and wildife surveys were conducted in conjunction with the proposed construction of a geothermal generating station and electrical transmission lines. The study area consisted of a 22-mile long by 2-mile wide corridor extending from the proposed generating station site (in the southwest corner of Baca 1) in a southeastern direction through the Baca site to Los Alamos.

Five collection sites were sampled for plant materials within the Baca site. An additional eight locations were sampled along the transmission corridor off the Baca site. Small mammal cencuses were conducted in representative habitat. Pellet transects were used to estimate deer and elk herd size in the study area. Roadside censuses were conducted to determine avifauna densities. Directed searches were conducted for the Jemez Mountain salamander and the peregrine falcon.

\subsection{SUMMARY AND SCOPE}

Nine vegetation habitats were identified during the study. These habitats were spruce-fir forest, mixed conifer forests, Ponderosa pine forests, aspen forest, open meadows, riparian vegetation, logged areas, tallus slopes and pinyon-juniper savannah. No threatened or endangered plants were found during the survey. However, the blue gramma grass cactus (Pediocactus papyracanthus) could occur in grasslands between 7500 and 5000 feet.

Six species of small mammals were trapped during the survey. The least diverse habitats were the dry meadows, spruce-fir forest, and logged areas. Ponderosa pine habitat was moderately diverse. The most diverse habitats were wet meadows, semixeric habitat and mixed conif er habitat.

Elk density was estimated to be 13 times greater than deer density. Elk sign was found in all portions of the study area except lower elevations near Los Alamos. Deer and elk densities were higher in fall and winter than summer, indicating the area was primarily used as migratory and winter habitat. Logged areas at Cerro del Medio were utilized heavily for calving during June and July.

One-hundred-nine species of birds were noted during the study. Avian diversity was highest in mixed conifer habitats. Logged habitats were second highest in density. Meadows were the least diverse habitat.

No specimens of the endangered Jemez Mountain salamander were found during the survey. There is a potential the the species would occur along some portion of the higher elevations of the corridor (above 8000 feet). 
SECTION

PAGE

1. Flora

1.1 Factors Affecting Plant Distribution

1.1.1 Climate

1.1.2 Physical Features

1.1.3 Plant Competition

1.1.4 Influences from Regional Vegetation Types

1.2 Previous Botanical Exploration

1.3 Materials and Methods

1.3.1 Location and Description of Collection Sites

1.3.2 Specimen Collection and Identification

1.4 Description of the Existing Vegetation

1.4.1 Habitat Types

1.4.2 Threatened and Endangered Species

1.5 Bibliography

33

1.6 Appendix

37

2. Fauna

47

2.1 Methods

48

2.1.1 Invertebrates

48

2.1.2 Mammals

2.1.3 Birds 


\section{TABLE OF CONTENTS OF THE REPORT (Continued)}

SECTION

PAGE

2.1.4 Reptiles and Amphibians $\quad 50$

$\begin{array}{lll}2.1 .5 & \text { Fishes } & 50\end{array}$

2.1.6 Rare, Threatened and Endangered Species 51

$\begin{array}{lll}2.2 & \text { Results and Discussions } & 52\end{array}$

2.2.1 Mammals $\quad 52$

$\begin{array}{lll}\text { 2.2.2 Birds } & 57\end{array}$

$\begin{array}{ll}\text { 2.2.3 Reptiles and Amphibians } & 64\end{array}$

$\begin{array}{lll}2.2 .4 & \text { Fishes } & 65\end{array}$

2.2.5 Rare, Threatened, and Endangered Species 65

$\begin{array}{lll}2.3 & \text { Bibliography } & 75\end{array}$

$\begin{array}{lll}2.4 & \text { Appendix } & 79\end{array}$ 
REPORT NO. 59

EXECUTIVE SUMMARY

SOCIOECONOMIC ANALYSIS FOR THE

PROPOSED BACA GEOTHERMAL PROJECT

FROM A REPORT

Prepared For

UNION GEOTHERMAL DIVISION

UNION OIL COMPANY OF CALIFORNIA

LOS ANGELES, CALIFORNIA

AND

PUBLIC SERVICE COMPANY

OF NEW MEXICO

ALBUQUERQUE, NEW MEXICO
Prepared By

MOUNTAIN WEST RESEARCH, INC.

TEMPE, ARIZONA

1979

Summary Prepared By

WESTEC SERVICES, INC.

ALBUQUERQUE, NEW MEXICO

MAY 1980 


\begin{abstract}
Public Service Company of New Mexico (PNM) and Union Geothermal of New Mexico (Union) requested that Mountain West Research, Inc. conduct appropriate socioeconomic studies and related work in preparation for an environmental impact statement to be filed by the Department of Energy (DOE). (The EIS has since been completed and filed.) This report represents the results of that impact assessment, including a description of the methods used and some suggested mitigation strategies for application in areas where possible adverse impacts may occur.

The types of socioeconomic effects that Mountain West evaluated are related to economic growth and community life. The general categories studied were economy, population, housing supply and demand, public services and facilities, transportation, recreation, land use, government fiscal analysis and social attitudes. Following an analysis of changes that introduction of the plant could cause, positive and negative aspects of the project relating to socioeconomic environment were assessed. Of particular interest were those benefits that were then unanticipated and those adverse conditions that were considered sufficiently serious to warrant some preliminary planning for their eventual mitigation.
\end{abstract}


The report began with a description of the proposed geothermal plant, the transmission line, and construction procedures for each, then described the existing environment focusing on a regional and local study area, presented the impact analysis, and concluded with proposed measures for mitigation of the determined socioeconomic difficulties.

The assessment procedure utilized throughout the report is in the format described below:

1) Sectors or activities that could be affected by the project were identified.

2) Future levels of activity were projected as they would be expected in the absence of the proposed project.

3) Future levels of activity were then projected with the proposed project.

4) The difference between the projections without the proposed project and those with the proposed project was the measure of impact.

\section{$2.0 \quad$ SCOPE}

Methodology: An integral part of the socioeconomic investigation was the agency and interest group contact program. The purpose of the program was to disseminate project information and gather the necessary data for completion of the socioeconomic analysis. Letters of introduction were sent to individuals in key governmental agencies at the federal, state and local levels, as well as to leaders of environmental interest groups in the state. These were followed by personal visits by members of Mountain West with participation by members of the Environmental Affairs Department at PNM and the staff at Union.

Impact Assessment: It was determined that the average peak year construction work force will be about 165 people, with the work force that would operate the plant and maintain the well field expected to be 55 people.

\section{Operation Period}

It was falt that the Baca project would be an important source of long-term or permanent employment for residents of the local impact study area. Approximately one-half of the 55 permanent jobs were anticipated to be held by existing residents of the Jemez Valley, and the other half split between existing residents of the three other subareas of the local impact study area: Bernalillo, San Ysidro and vicinity, and Los Alamos. 
Overall, it was felt that the long-term impacts of the project should be generally beneficial. The plant represents a significant increase in the economic base of the Jemez Valley. These jobs would lead to increased income and better employment, both in terms of salary levels and job stability. This would probably cause some new housing construction and a gradual attraction of the work force to the Jemez Valley as singlefamily units become available there. Also, substantial fiscal benefits should accrue to Sandoval County. ' No significant adverse impacts were anticipated in the long-term, especially if care were taken to maintain good relations during the construction period with the communities in the Jemez Valley.

\section{Construction Period}

Housing for construction workers was determined to be a potential problem during this time, especially in the Jemez Valley. In addition, travel along State Highway (NM) 4 is expected to increase approximately 11 percent, and during the peak hour by 29 percent. The greatest increase in traffic will occur during the peak employment period, approximately three months, and will be about 63 percent greater. This will create an incremental increase to the presently unsafe conditions at potentially hazardous locations. A third impact is anticipated to occur to an already minimal number of indoor recreation facilities and opportunities in the Jemez area. A fourth possible problem with the fiscal impact is that an imbalance may arise from the spatial difference between where the new expenditures might be required and where the plant-related revenue increases would occur.

Potential Mitigation Measures. 1) To mitigate any housing impacts, the most favorable solutions were either development of a temporary $\mathrm{RV} /$ trailer park on leased land in Jemez Springs, or locating workers as near as possible to the plant site either in Jemez Springs, campgrounds or wherever it may be feasible to locate facilities in the Santa $\mathrm{Fe}$ National Forest; 2) in order to decrease potential unsafe travel along NM 4, the energy companies should begin to inform the Department of Highways Planning Department of the traffic increases that are expected. Because major traffic congestion problems are not anticipated during the project, this strategy of early notification to highway maintenance authorities is expected to assuage the potential problems; 3 ) to mitigate potential impact to the recreation facilities, it was suggested that the development companies contact the local school board and request initiation of several athletic nights at the gymnasium in Canon, and that the companies establish a continual communication with local government officials regarding recreation in the area where the temporary workers settle; 4) to improve fiscal imbalances, the County could award grants from a fund established by a certain amount of the property tax revenues to local governments anticipating necessary improvements; 5 ) because the general route of the transmission line corricor had not been determined during the course of this study, 
yet was an identified areawide concern, it was advised that the companies plan a pubilic information program to advise area residents and the greater public of the final corridor selection.

\subsection{SUMMARY}

This study presented a complete break down of the existing socioeconomic environment, formulated potential impacts created by both construction and ongoing operation of the proposed geothermal plant, and presented mitigation measures to alleviate these impacts. 
1. INTRODUCTION

2. DESCRIPTION OF THE PROPOSED GEOTHERMAL PLANT, THE TRANSMISSION LINE AND THEIR CONSTRUCTION

2.1 Brief Technical Highlights

2.2 Construction Schedule

2.3 Manpower Requirements

3. EXISTING ENVIRONMENT 10

$\begin{array}{lll}3.1 & \text { Definition of Study Areas } & 10\end{array}$

3.2 Description of the Regional Impact Study Area 17

3.2.1 Economics and Demographics of the Region 17

3.2.2 Recreational Features 25

$\begin{array}{lll}\text { 3.2.3 Transpoptation Network } & 29\end{array}$

3.3 Characteristics of the Communities in the Local Impact
Study Area

$\begin{array}{ll}\text { Study Area } & 32 \\ 3.3 .1 \quad \text { Economics } & 32\end{array}$

3.3.2 Demographics 34

$\begin{array}{lll}\text { 3.3.3 Housing } & 38\end{array}$

3.3.4 Public Services and Facilities $\quad 41$

3.3.5 Transportation 45

3.3.6 Recreation 45

3.3.7 Government Revenues and Expenditures 46

3.3.8 Land Use $\quad 51$

$\begin{array}{lll}\text { 3.3.9 Social Concerns } \quad \text { - } & 54\end{array}$

4. IMPACT ASSESSMENT $\quad 56$

4.1 Labor Analysis During Construction and Operation 56

4.1.1 Availability of Labor $\quad 57$

4.1.2 Operation Period Labor Analysis 57

4.1.3 Construction Period Labor Analysis $\quad 58$

$\begin{array}{lll}4.2 & \text { Economics } & 61\end{array}$

4.3 Housing and Worker Location $\quad 64$

4.3.1 Construction Period 64

$\begin{array}{ll}\text { 4.3.2 Operation Period } & 65\end{array}$

$\begin{array}{lll}\text { 4.4 Demographics } & 66\end{array}$

$\begin{array}{ll}4.5 & \text { Public Services and Facilities }\end{array}$

4.6 Transportation and Highways 68

4.7 Recreation 70

4.8 Government Revenues and Expenditures $\quad 70$

4.9 Land Ownership and Uses $\quad 72$

4.10 Social and Cultural Life $\quad 73$

4.11 Summary of Impacts 74 
TABLE OF CONTENTS FOR THIS REPORT (Continued)

TITLE

PAGE

5. POSSIBLE MEASURES FOR THE MITIGATION OF SOCIOECONOMIC DIFFICULTIES

5.1 Suggested Options for Each Impact

5.1.1 Housing Strategies

5.1.2 Transportation System

5.1.3 Indoor Recreation/Com

5.1 .4 Improving Fiscal Balances in the Local Impact Area

5.1 .5 Promotion of Local Employment

5.1.6 Potential Disruption Due to the Transmission Line

82

5.2 Summary of Projected Mitigation Program

APPENDIX A. AGENCY CONTACT LIST

APPENDIX B. COMMUNITY DEVELOPMENT ALTERNATIVES

LIST OF FIGURES OF THE REPORT

TITLE

$\underline{\text { PAGE }}$

1.1 Proposed Baca Geothermal Demonstration Project

2.1 Construction and Operation Employees, Baca Geothermal Demonstration Plant

3.1 Regional Impact Study Area of Baca Geothermal Project

3.2 Local Impact Study Area

3.3 Percent of Population by Age and Sex

3.4 Average Daily Trip Counts, 1978

3.5 Age Structure of the Los Alamos Population, 1960 and 1970 
TABLE OF CONTENTS FOR THIS REPORT (Continued)

LIST OF TABLES OF THE REPORT

TITLE

$\underline{\text { PAGE }}$

2.1 Baca Geothermal Demonstration Plant Employment Schedule

3.1 Commuting Times to Baca Geothermal Plant Site from Communities in the Regional Impact Area

3.2 Skilled Labor Availability in North Central New Mexico, April 1978

3.3 County Data on Employment and Income in the Regional Impact Area 1970 and 1974

3.4 Recent Labor Force and Unemployment Rates in the Regional Impact Area

3.5 Recent Income Information on the Counties in the Regional Impact Area

3.6 Recent Population Growth in the Area Surrounding the Baca Project

3.7 Population Distribution by Race, $1970 \quad 24$

3.8 Population Density and Urbanization, 1960 and $1970 \quad 24$

3.9 Recreational Use of Senta Fe National Forest Lands, 1975 and 1976

3.10 Employment Shares in Los Alamos, by Place of Work, 1967 to 1974 With Projections to 1980

3.11 Population Projections for Los Alamos County, 1975-1980 36

3.12 Population of Jemez Springs by Age and Sex, 1970

3.13 Increases in Housing Units in Sandoval County, 1975 to 1976

3.14 Survey of Housing Conditions in Sandoval County, 1976

3.15 Housing Characteristics of Los Alamos County, Sandoval County, and Jemez Springs, 1970 Census

3.16 Services and Facilities in the Jemez Springs and Los Alamos Communities 
TABLE OF CONTENTS FOR THIS REPORT (Continued)

LIST OF TABLES OF THE REPORT (Continued)

TITLE

$\underline{\text { PAGE }}$

3.17 Estimated Revenue and Expenditures for Sandoval County, Fiscal Year 1978

48

3.18 Estimated Revenue and Expenditures of the Sandoval County Schools: Bernalillo, Cuba and Jemez Springs School Districts, Fiscal Year 1978

3.19 Combined City and County Budget of Los Alamos County, Fiscal Year 1978 and 1979

3.20 Municipal Budget of the Village of Jemez Springs, Fiscal Year 1978 and 1979

4.1 Bokum Resources Uranium Mill Local/Non-Local Composition of Workforce

4.2 New Mexico Craft Wage Rates at the San Juan Power Plant, September 1978 


\author{
REPORT NO. 60 \\ EXECUTIVE SUMMARY \\ PUELIC HEARING ON THE \\ ENVIRONMENTAL IMPACT STATEMENT \\ GEOTHERMAL DEMONSTRATION PROGRAM \\ AUGUST 30,1979 \\ TRANSCRIPT OF PROCEEDINGS
}

Prepared For

THE UNITED STATES OF AMERICA

DEPARTMENT OF ENERGY

ALBUQUERQUE, NEW MEXICO
Prepared By

HOWARD W. HENRY \& COMPANY

ALBUQUERQUE, NEW MEXICO

Summary Prepared By

WESTEC SER VICES, INC.

ALBUQUERQUE, NEW MEXICO

MARCH 1980 


\begin{abstract}
On August 30, 1979, a public hearing was held on the Environmental Impact Statement submitted by the U. S. Department of Energy (DOE) on the $50 \mathrm{MW}$ Geothermal Demonstration Program at the Baca Location No. 1 in North-Central New Mexico, to hear testimony on whether the United States Government should accept the EIS as complete. The participants in the proposed project at that time were Public Service Company of New Mexico (PNM) and Union Geothermal of New Mexico (Union). Representatives of DOE, PNM, Union and the legal community were available for questions. Presentations were made by DOE, the Bureau of Indian Affairs, the All Indian Pueblo Council, the Pueblo of Zia, the Jemez Pueblo, the Cochiti Tribe, the Los Alamos Mountaineers, and various other institutions and private citizens. This report is the transeript of the proceedings as recorded by a court reporting service.
\end{abstract}




\section{HEARING APPEARANCES}

MR. THOMAS A. HARRELL, Chariman

MR. ROBERT P. HARTLEY, Member

MR. JOSE L. M. CORTEZ, Member

TECHNICAL PANEL

MR. ARTHUR C. WILBUR

Department of Energy

MR. JACK MADDOX

Public Service Company of New Mexico

MR. DICK ENGEBRETSEN

Union Oil

MR. HARRY AR NOLD

MS. KATHY OAKES

MS. MARY MORAN 


\title{
REPORT NO. 61 \\ EXECUTIVE SUMMARY
}

FIN AL EN VIRONMENTAL IMPACT STATEMENT

GEOTHERMAL DEMONSTRATION PROGRAM

50 MW POWER PLANT

FROM A REPORT

\author{
Prepared By \\ UNITED STATES OF AMERICA \\ DEPARTMENT OF ENERGY \\ IV ASHINGTON, D. C. \\ JANUARY 1980
}

Summary Prepared By

WESTEC SER VICES, INC.

ALBUQUERQUE, NEW MEXICO

MARCH 1980 
This report is the Final Environmental Impact Statement (FEIS) of the 50 MW Geothermal Demonstration Plant of the Baca Location No. 1 in North-Central New Mexico, as published in January 1980. This FEIS was submitted after a draft EIS (DEIS) was considered by the public sector and comments were submitted on its content. This FEIS, as do all FEIS's, considers impacts and possible mitigations of all aspects of the project on land use, geology, soils, geothermal resources, hydrology and water quality, meteorology and air quality, ecology, historic and archeological resources, socioeconomy, noise, visual resources, and Pueblo Indian culture and religion. The FEIS also considers impacts of whether or not the project is approved, environmental trade-of fs, and an analysis of the steady-state impact of the operating plant. Written comments to the DEIS are attached as an appendix.
\end{abstract}


In pursuit of the Federal Geothermal Program objective to accelerate the commercialization of geothermal energy in an environmentally sound manner, the DOE issued a program opportunity notice (PON) on September 30, 1977, inviting organizations to submit proposals for the design, construction, and operation of a geothermal electric power plant. The PON specified that the power plant must (1) use a liquid-dominated geothermal reservoir, and (2) be located in the United States. The objectives of the PON were chosen to provide the maximum stimulus to non-Federal development of the widest spectrum of hydrothermal resources that can be used for electricity production.

The Federal action addressed by this Environmental Impact Statement is joint funding by the Department of Energy and commercial partners of a $50 \mathrm{MW}(\mathrm{e})$ geothermal well field, power plant, and transmission line at the Baca Location in Sandoval County, New Mexico. The power plant will utilize a single-flash steam separation system and mechanical-draft cooling towers and will use cooled geothermal fluid for cooling. The geothermal well field will initially consist of up to 17 wells producing fluid from an area of approximately 300 ha ( 746 acres), including up to 176 new wells to be added during the 30 years of operation.

A $115 \mathrm{kV}$ transmission line will be constructed from the project site to the TA-3 substation near Los Alamos. The line will be capable of carrying up to $150 \mathrm{MW}$ of capacity and will be approximately $30 \mathrm{~km}$ in length. The two routings proposed will traverse private land, portions of the Santa Fe National Forest, and the Los Alamos Scientific Laboratory. One of the proposed routes will cross the Bandelier National Monument.

The proposed plant is situated along the Redondo and Jaramillo Creeks graben within the Valles Caldera, a major Quaternary volcanic center superimposed upon the western margin of the Rio Grande rift, a first-order tectonic feature. Volcanic rocks and caldera fill material of Pleistocene age crop out at the surface overlying a sequence of perhaps $3800 \mathrm{~m}(12,400+$ feet $)$ of older Quaternany and Tertiary volcanics, Tertiary sands, Paleozoic sedimentary rocks, and a Precambrian granitic basement complex. Produced heat flow values at the site are high, exceeding $3 \mu \mathrm{cal} / \mathrm{cm}^{2}$. A gravity anomaly of 25 milligals is coincident with the project area. The closest known active fault zone, in Jemez, lies to the southwest of the Valles Caldera. No significant seismic events have been recorded near the project site.

The geothermal resources of the project area include both a liquid and a vapor-dominated reservoir. The calculated weight of fluid in place in the major, liquid-dominated reservoir is $1.8 \times 10^{12} \mathrm{~kg}\left(4 \times 10^{12} \mathrm{lb}.\right)$. The average reservoir fluid temperature is in excess of $260^{\circ} \mathrm{C}\left(500^{\circ} \mathrm{F}\right)$. The main production and injection zone is the lower Bandelier Tuff; the upper Bandelier forms the caprock. 
The principal effluents from the power plant are nonflashed, hot geothermal fluid, which will be injected, and geothermal vapor released to the atmosphere from the cooling towers. The liquid contains lightly concentrated dissolved solids, and the vapor contains small amounts of noncondensible gases, including hydrogen sulfide.

\section{$2.0 \quad$ SUMMARY AND CONCLUSIONS}

Releases of hydrogen sulfide during normal operation will result in increases of $\mathrm{H}_{2} \mathrm{~S}$ concentrations in the air of less than $2 \mathrm{ppb}$ at the Baca boundary and less than $10 \mathrm{ppb}$ at other locations within the Baca Location. Accidents or abnormal operation conditions may infrequently result in concentrations exceeding these values for infrequent intervals of up to several hours.

Induced subsidence of the land surface resulting from geothermal fluid production is not expected to be likely or measurable at the surface and may even be less significant than that occurring naturally. The proposed fluid injection pressures and temperatures are within a range not likely to initiate any significant earthquake activity as a result of hydraulic fracturing or thermal stress cracking of the reservoir rocks. Induced seismicity at the project site will probably be obscured by natural seismicity.

Potential impacts resulting from development of the $50 \mathrm{MW}(\mathrm{e})$ geothermal well field, power plant, and transmission line are summarized in Table 1-1 included in the executive summary.

Comments on the DEIS were grouped into the major categories of (1) inadequate analysis of expansion beyond the Federal action, (2) inadequate treatement of American Indian religious impacts, (3) critiques of the technical methods of irnpact estimation, particularly for hydrology and air quality, (4) potential future public ownership of the Baca Ranch, and (5) transmission line alternative discussions. These comments have been included in Appendix I of the EIS, addressed generally in Section 12, and resulted in expanded discussion in appropriate sections of the EIS. 
1. SUMMARY

2. DESCRIPTION OF THE PROPOSED FEDERAL ACTION

2.1 PURPOSE AND POLICY OBJECTIVES

2.2 GENERAL DESCRIPTION OF PROPOSED PROJECT

2.2.1 Historical project information

2.2.2 Site location and surface features

2.2.3 Well field development and plant construction

2.2.3.1 Drilling and well testing

2.2.3.2 Road and pipeline construction

2.2.3.3 Power plant construction

2.2.4 Transmission lines

2.2.4.1 Transmission line design

2.2.4.2 Transmission line construction

2.2.4.3 Transmission line maintenance

2.2.5 Plant operation

2.2.5.1 Power cycle

2.2.5.2 Ef fluents of operations

2.2.5.3 Water use

2.3 RECLAMATION AND RESTORATION

2.4 TANGIBLE BENEFITS

2.5 EXPANSION OF GEOTHERMAL DEVELOPMENT BEYOND 50 MW(e)

2.5.1 Development of $150 \mathrm{MW}(\mathrm{e})$

2.5.2 Development of 400 MW(e)

2.5.3 Future transmission systems for $400 \mathrm{MW}(\mathrm{e})$

2.5.4 Expansion beyond 400 MW(e)

2.5.5 Future transmission system for greater than $400 \mathrm{MW}(\mathrm{e})$

REFERENCE FOR SECTION 2

3. DESCRIPTION OF EXISTING ENVIRONMENT

3.1 REGIONAL SETTING AND MAIN PROJECT AREA

3.1.1 Land Use

3.1.1.1 Land ownership

3.1.1.2 Preservational designations and

3.1.1.3 Other existing land uses

3.1.1.4 Planned future land uses

3.1.1.5 Well field and plant site

3.1.2 Geology, soils, and geothermal resources

3.1.2.1 Geology

3.1.2.1.1 Regional

3.1.2.1.2 Site-specific

3.1.2.1.3 Seismicity

3.1.2.1.4 Geologic hazards

3.1.2.2 Soils

3.1.2.3 Geothermal resources 
TABLE OF CONTENTS (CONTINUED)

3.1.3 Hydrology and water quality

3.1.3.1 Surface water

3.1.3.1.1 Surface water quality

3.1.3.1.2 Surface water use

3.1.3.2 Groundwater

3.1.3.2.1 Occurrence and quality

3.1.3.2.2 Use

3.1.4 Meteorology and air quality

3.1.4.1 Climate

3.1.4.1.1 General influences

3.1.4.1.2 Winds

3.1.4.1.3 Precipitation

3.1.4.1.4 Temperature

3.1.4.2 Air quality

3.1.5 Ecology

3.1.5.1 Terrestrial ecology

3.1.5.1.1 Vegetation

3.1.5.1.2 Fauna

3.1.5.1.3 Well field and plant site

3.1.5.2 Aquatic ecology

3.1.5.3 Endangered species

3.1.5.3.1 Plants

3.1.5.3.2 Animals

3.1.6 Historic and archeological resources

3.1.6.1 Historic sites

3.1.6.2 Archeological resources

3.1.6.3 Other areas

3.1.7 Social and community profile and demography

3.1.7.1 Introduction

3.1.7.2 Construction schedule and manpower requirements

3.1.7.3 Demography and impact area identification

3.1.7.4 Local communities

3.1.7.4.1 Housing

3.1.7.4.2 Public services

3.1.7.5 Labor supply

3.1.7.6 Transportation

3.1 .8 Noise

3.1.8.1 Noise characteristics on the site

3.1.8.2 Noise regulations

3.1.9 Visual resources of the region

3.1.10 Pueblo Indian culture and religion

3.1.10.1 Geographical setting

3.1.10.2 Ways of life

3.1.10.3 Concept of reality

3.1.10.4 Religious beliefs and practices

3.1.10.5 Sacred sites 


\subsection{TRA NSMISSION CORRIDORS}

3.2.1 Land ownership and use

3.2.2 Ecology

3.2.3 Soils

3.2.4 Archeology

3.2.5 Visual resources

REFERENCES FOR SECTION 3

4. IMPACTS OF THE PROPOSED PROJECT

4.1 IMPACTS OF CONSTRUCTION WELL FIELD AND POWER PLANT

4.1.1 Impacts on land use

4.1.2 Impacts on water quality and use

4.1.3 Air quality

4.1.4 Impacts on biota

4.1.4.1 Impacts on terrestrial biota

4.1.4.2 Impacts on aquatic biota

4.1.4.3 Impacts on rare and endagered species

4.1.5 Socioeconomical and cultural impacts

4.1.5.1 Regional historic and archeological

sites

4.1.5.2 Cultur.al impacts

4.1.5.3 Community impacts

4.1.5.4 Economics

4.1.5.5 Labor

4.1.5.6 Transportation

4.1.6 Noise impacts

4.1.7 Impacts on Indian religious values

4.1.7.1 Destruction of religious sites

4.1.7.2 Destruction of sacred objects

4.1.7.3 Invasion of privacy

4.1.7.4 Interference from transmission lines

4.1.7.5 Contamination and/or loss of water

4.1.7.6 Depletion of sacred springs

4.1.7.7 Interference with access to religious sites

4.2 IMPACTS OF OPERATION

4.2.1 Impacts on land use

4.2.2 Water quality and use

4.2.2.1 Surface water

4.2.2.2 Groundwater

4.2.3 Air quality impacts

4.2.3.1 Daytime dispersion conditions

4.2.4.2 Nocturnal dispersion conditions

4.2.4.3 Cooling tower drift

4.2.4 Impacts on ecological system

4.2.4.1 Terrestrial

4.2.4.2 Aquatic ecology

4.2.4.3 Impacts on rare and endangered species 
4.2.5 Seismic and geologic-related impacts

4.2.6 Noise impacts

4.2.7 Socioeconomic and cultural impacts

4.3 POTENTIAL ACCIDENTS

4.3.1 Abnormal plant operation

4.3.1.1 Loss of hydrogen sulfide abatement

system

4.3.1.2 Loss of fluid injection system

4.3.2 Turbine trip

4.3.3 Geothermal fluid system failure

4.3.3.1 Blowouts

4.3.3.2 Pipe ruptures

4.3.3.3 Failure of drilling sump

4.4 IMPACTS OF TRANSMISSION LINES

4.4.1 Construction

4.4.1.1 Land use

4.4.1.2 Ecological impacts

4.4.1.3 Soil-related impacts

4.4.1.4 Impacts on archeological and cultural resources

4.4.1.5 Visual impacts

4.4.2 Impacts of operation

4.4.3 Comparison of corridors

4.5 IMPACTS OF FUTURE EXPANSION BEYOND $50 \mathrm{MW}$

4.5.1 $150 \mathrm{MW}$

4.5.1.1 Land use

4.5.1.2 Hydrologic

4.5.1.3 Air quality

4.5.1.4 Impacts to biota

4.5.1.5 Socioeconomic

4.5.1.6 Religious values

4.5.2 Expansion beyond 150 MW (up to $400 \mathrm{MW}$ )

4.5.2.1 Land use

4.5.2.2 Hydrollogic

4.5.2.3 Air quality

4.5.2.4 Impacts on ecological systems

4.5.2.5 Socioeconomic

4.5.2.6 Religious values

4.5.3 Additional transmission facilities

REFERENCES FOR SECTION 4

5. UNAVOIDABLE ADVERSE IMPACTS

6. IRREVERSIBLE AND IRRETRIEVABLE COMMITMENT OF RESOURCES

7. RELATIONSHIP OF LAND USE, POLICIES AND CONTROLS

7.1 PERMITS AND REGULATIONS

7.2 POTENTIAL LAND USE PLANS AND CONFLICTS

7.3 OTHER INTERESTED PARTIES

REFERENCES FOR SECTION 7 
8. THE RELATIONSHIP BETWEEN SHORT-TERM USES OF THE ENVIRONMENT AND THE MAINTENANCE OF LONG-TERM PRODUCTIVITY

9. ALTER NATIVES

9.1 NO FEDERAL ACTION

9.2 DELAY OF FEDERAL ACTION

9.3 FUNDING OF A NONELECTRIC USE OF THE RESOURCE

9.4 FUNDING OF ALTER NATIVE SITES WITHIN THE BACA LOCATION

9.4.1 Redondo Canyon

9.4.2 Sulphur Creek area

9.5 FUNDING OF ALTER NATIVE SITES AT OTHER LOCATIONS

IN THE UNITED STATES

9.5.1 Imperial Valley sites

9.5.2 Roosevelt Hot Springs

9.5.3 Beowawe

9.6 ALTER NATIVE PLANT DESIGNS

9.6.1 Cooling system alternatives

9.6.1.1 Natural-draft towers

9.6.1.2 Dry towers

9.6.1.3 Wet/dry towers

9.6.1.4 Fresh makeup water supply

9.6.2 Hydrogen sulfide abatement system alternatives

9.6.2.1 Iron catalyst method

9.6.2.2 Upstream absorption scrubbers

9.6.3 Alternative power cycles

9.6.3.1 Binary cycle

9.6.3.2 Dual-flash cycle

9.6.4 Alternative flash unit location

9.7 ALTER N ATIVE TRA NSMISSION CORRIDORS

REFERENCES FOR SECTION 9

10. ENVIRONMENTAL TRADE-OFF ANALYSIS

10.1 ACTION ALTER N ATIVES

10.2 SITE ALTERNATIVES

10.2.1 Alternative sites in the Baca Location

10.2.2 Alternative sites at other goethermal areas

10.3 ALTER NATIVE PLANT DESIGNS

10.3.1 Power cycle and cooling systems

10.3.2 Hydrogen sulfide abatement

10.4 ALTER NATIVE TRANSMISSION LINES

11. MITIGATION AND MONITORING

11.1 MITIGATION

11.1.1 Construction

11.1.1.1 Land use

11.1.1.2 Water quality and use

11.1.1.3 Air quality

11.1.1.4 Impacts on biota

11.1.1.5 Impacts on historic and

archeological sites

61.9 
TABLE OF CONTENTS (CONTINUED)

11.1.1.6 Impacts on Indian religious and cultural activities

11.1.1.7 Noise impacts

11.1.2 Plant operations

11.1.2.1 Land use

11.1.2.2 Water quality and use

11.1.2.2.1 Surface water

11.1.2.2.2 Groundwater

11.1.2.3 Impacts on air quality: hydrogen sulfide mitigation

11.1.2.4 Impacts on biota

11.1.2.5 Seismic and geologic-related impacts

11.1.3 Potential accidents

11.1.3.1 Blowouts

11.1.3.2 Pipe rupture

11.1.4 Mitigation for transmission lines

11.2 MONITORING

11.3 PREOPERATIONAL MONITORING

11.3.1 Ecological

11.3.1.1 Terrestrial

11.3.1.2 Aquatic

11.3.2 Hydrologic

11.3.3 Atmospheric mionitoring

11.4 OPERATIONAL MONITORING

11.4.1 Ecological

11.4.1.1 Terrestrial

11.4.1.2 Aquatic

11.4.2 Hydrologic

11.4.3 Atmospheric monitoring

11.5 ENFORCEMENT

REFERENCES FOR SECTION 11

12. DISCUSSION OF COMMENTS RECEIVED CONCERNING THE DRAFT

EN VIRONMENTAL IMPACT STATEMENT

12.1 PUBLIC MEETING WITH PUEBLO REPRESENTATIVES

12.2 PUBLIC HEARING

12.3 SUMMARY OF COMMENTS

12.3.1 Infringement on religious freedom and desecration of sacred sites

12.3.2 Effects of geothermal development beyond the initial $50 \mathrm{MW}$ plant

12.3.3 Transmission line corridor impacts

12.3.4 Surface water and groundwater inpacts

12.3.5 Air quality degradation

12.3.6 Disturbance of historic sites and degradation of natural scenic beauty

12.3.7 Socioeconomic and cultural impacts on local communities

12.3.8 Failure to adequately consider alternatives 
TABLE OF CONTENTS (CONTINUED)

13. LIST OF PREPARERS AND QUALIFICATIONS

13.1 REPORT PREPARERS

13.1.1 Project Manager

13.1.2 Project deseription

13.1.3 Description of existing environment and impact analysis

13.1.3.1 Land use

13.1.3.2 Geology, soils, and geothermal resources

13.1.3.3 Hydrology and water quality

13.1.3.4 Meteorology and air quality

13.1.3.5 Ecology

13.1.3.6 Historic and archeological resources

13.1.3.7 Social and community profile and demography

13.1.3.8 Noise

13.1.4 Transmission corridors

13.1.5 Unavoidable adverse impacts

13.1.6 Irreversible and irretrievable commitment of resources

13.1.7 Relationship of land use plans, policies, and controls

13.1.8 The relationship between short-term uses of the environment and the maintenance of longterm productivity

13.1.9 Alternatives

13.1.10 Environmental trade-of $f$ analysis

13.1.11 Mitigation and monitoring

13.1.11.1 Ecology

13.1.11.2 Hydrology

13.1.11.3 Air quality

13.1.11.4 Historic and archeological

13.2 OTHER CONTRIBUTORS

APPENDIX A - MAPS SHOWING LOCATIONS OF THERMAL SPRINGS IN THE VALLES CALDERA-JEMEZ VALLEY REGION, NEW MEXICO

APPENDIX B - DESCRIPTION OF VEGETATION COMMUNITIES OCCURRING IN THE BACA S'TUDY REGION

APPENDIX C - PRIME AND UNIQUE FARMLAND CORRESPONDENCE

APPEN DIX D - THE FOREST SER VICE VISUAL MANAGEMENT SYSTEM

APPENDIX E - NATIONAL REGISTER OF HISTORIC PLACES - ELIGIBILITY

OF 29 STATES AND 1 LOCALITY AND DETERMINATION OF NO ADVERSE EFFECT 
TABLE OF CONTENTS (CONTINUED)

$\underline{\text { PAGE }}$

APPENDIX F - APPROVED MITIGATION PLANS FOR EFFECTS ON RARE AND ENDANGERED SPECIES

APPENDIX G - EMERGENCY ACCIDENTAL SPILLS AND DISCHARGES CONTROL PROCEDURES AND SPILL PREVENTION CONTROL AND COUNTERMEASURE PLAN

APPENDIX H - DEIS HEARING BOARD SUMMARY AND RESPONSES

APPENDIX I - COMMENTS AND RESPONSES

APPENDIX J - ADDITIONAL COMMENTS RECEIVED DURING CONSULTATION PROCESS IN COMPLIANCE WITH THE AMERICAN INDIAN RELIGIOUS FREEDOM ACT 


\section{LIST OF FIGURES OF THE REPORT}

FIGURE

2.1 Present surface ownership of the Baca Location No. 1 Land Grant and the general location of the well field and plant site

2.2 Regional location of the Baca Location No. 1 Land Grant and the plant site and surrounding well field

2.3 Typical equipment layout of a geothermal exploration well

2.4 Typical flow schematic of two-phase well

2.5 Fluid production pipeline system

2.6 Injection pipeline system schematic

2.7 Geographic map of the Valles Caldera

2.8 Power plant site plan

2.9 Map showing proposed transmission corridor

2.10 Typical $115 \mathrm{kV}$ wood-pole $\mathrm{H}$-frame transmission tower structure

2.11 Schematic diagram of power system

2.12 Geothermal leases on Federal land surrounding the Baca Location

3.1 Land ownership of area surrounding Baca Location

3.2 Preservational and recreational areas surrounding Baca Location

3.3 Existing and planned residential land use and services in Baca study region

3.4 Location of proposed and existing wells and roads within well field Redondo Canyon

3.5 Regional geologic setting of the Valles Caldera

3.6 Geographic map of Valles Caldera

3.7 Geologic map of Valles Caldera

3.8 Geologic map of Redondo Creek

3.9 Cross section of the Valles Caldera

3.10 Structure section of Redondo Creek 
FIGURE

3.11 Bouguer Gravity map of Valles Caldera

3.12 Geothermal features of the Valles Caldera

3.13 Generalized soils map of the project site

3.14 Soils map of Santa Fe County, New Mexico, along the proposed transmission line route

3.15 Soils map of Bandelier National Monument

3.16 Soils map of Los Alamos County, New Mexico, along proposed and alternate transmission line corridors

3.17 Surface waters in the vicinity of the Baca Geothermal Project

3.18 Generalized schematic diagram of Valle Grande showing movement of groundwater

3.19 Vegetation map of Baca study region

3.20 Known elk summer and winter use areas within the Baca study region

3.21 Detail of location of areas used by overwintering herds of elk within the vicinity' of the main project site

3.22 Location of know Jemez Mountains salamander habitat within the vicinity of the Baca study region

3.23 Regional impact study area

3.24 Local impact study area

3.25 Visual resources surrounding the Baca Location

3.26 Present-day Rio Grande Pueblos

4.1 Noise levels from geothermal operations

4.2 Baca wells annual wind rose, 10AM - 7PM

4.3 Baca wells annual wind rose, 7PM - 10AM

4.4 Calculated hydrogen sulfide concentrations at ground level during daytime $\mathrm{C}$ conditions 


\section{LIST OF FIGURES OF THE REPORT}

FIGURE

4.5 Topographical influences on ground level concentrated along a transect going roughly northeast from the proposed plant site

4.6 Upper forks annual wind rose, $7 \mathrm{pm}-10 \mathrm{AM}$

4.7 Calculated hydrogen sulfide concentrations at ground level for drainage layer depth of $215 \mathrm{~m}$

4.8 Five feasible egress routes for $345 \mathrm{kV}$ capacity from

Baca to the existing and present planned 115 and $345 \mathrm{kV}$ grid

9.1 Map of Imperial Valley

9.2 Map showing proposed transmission corridor

A-1 Valles Caldera-Jemez Valley region, New Mexico, showing areas covered by index maps

A-2 Spring location index map A

A-3 Spring location index map C

A-4 Spring location index map D

A-5 Spring location index map $E$

A-6 Spring location index map $\mathrm{H}$

A-7 Spring location index map $P$ 
1.1 Summary of potential impacts of the $50 \mathrm{MW}(\mathrm{e})$ geothermal well field, power plant, and transmission line at the Baca site

2.1 Average chemical analysis of steam (without scrubbing)

3.1 Earthquake intensity and magnitude scale

3.2 Interpretation of the soil mapping units of the Baca project site and proposed transmission line route

3.3 Water chemistry of Redondo Creek

3.4 Average water quality data for the combined flows of Sulphur and Redondo Creeks (Sulphur Creek)

3.5 Water chemistry of the Jemez River at Battleship Rock, immediately below the confluence of San Antonio Creek at the east fork of the Jemez River

3.6 Statistics on fishing effort, harvest, and economic values of the Jemez River fishery during the 1975-1976 license year

3.7 Records of thermal (temperature above $15^{\circ} \mathrm{C}\left(59^{\circ} \mathrm{F}\right)$ ) springs in the Valles Caldera-Jemez Valley region, New Mexico

3.8 Geothermal fluid analyses for Baca wells

3.9 Average chemistry of produced fluid

3.10 Average noncondensible gas chemistry

3.11 Hunter harvest data for elk management unit 9, which include the entire Jemez Mountains

3.12 Threatened and endangered species on New Mexico and Federal lists whose ranges possibly extend to the study region

3.13 Commuting times to Baca geothermal plant site from communities in the regional impact area

3.14 Recent population growth in the area surrounding the Baca project

3.15 Services and facilities in the Jemez Springs and Los Alamos communities 
LIST OF TABLES (CONTINUED)

TABLE

3.16 Skilled labor in North-Central New Mexico, April 1978

3.17 Typical "A"-weighted sound levels and human response

3.18 Dimensions and associated natural phenomena of the Pueblo world

3.19 Illustrative list of Pueblo sacred sites

3.20 Environmental characteristics for the two proposed transmission corridors from the Baca plant to the TA-3 substation

4.1 Baca geothermal demonstration plant employment schedule

4.2 Estimated noise levels at Redondo Creek

4.3 "A"-weighted sound levels from various noise sources at The Geysers at a typical power plant operating at full load

4.4 Maximum concentrations of trace constituents in geothermal fluids at the Baca site in relation to minimum concentrations known to be toxic to aquatic biota

4.5 Predicted concentrations of arsenic, boron, bromine, and iron in surface water of the Jemez River at Battleship Rock during 16-year low and mean flows, following hypothetical rupture of a pipeline adjacent to Redondo Creek

4.6 Visual consideration of the two proposed transmission corridors

9.1 Land ownership in New Mexico and Colorado rivers

9.2 Land ownership for alternative routes I and II

10.1 Environmental characteristics of alternative sites in the Baca Location

10.2 Environmental characterisites of the proposed and alternative sites

10.3 Environmental aspects of alternative cooling system and power cycles 


\section{LIST OF TABLES (CONTINUED)}

\section{TABLE}

PAGE

D.l Sensivity level criteria for travel routes and use areas

D.2 Visual objective matrix 
TABLE 1.1 OF THE REPORT

61.19 


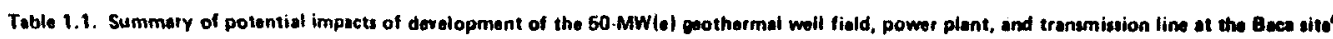

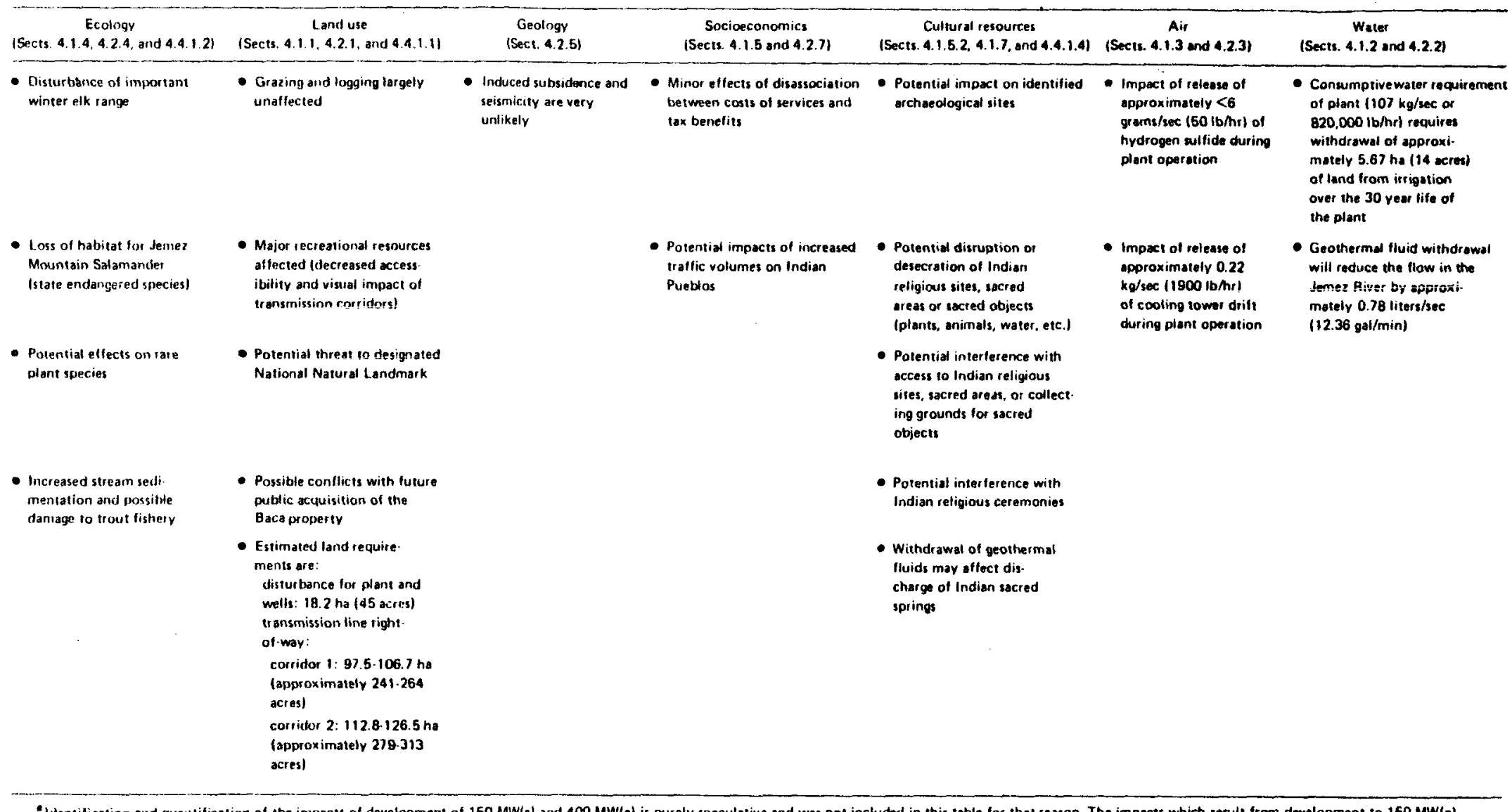

- Identification and quartification of the impacts of development of $150 \mathrm{MW}(\mathrm{el}$ a and $400 \mathrm{MW}(\mathrm{e})$ is purely speculativa and was not included in this rable for that reason. The impacts which result from devel opment to $150 \mathrm{MW}(\mathrm{el}$ and $400 \mathrm{MW}(\theta)$ will be simitar to those presented in this table; however, their magnitude will differ, Discussions of the impacts of development of $150 \mathrm{MWW}(\mathrm{s})$ and $400 \mathrm{MW}(\mathrm{e})$ are found in Sect. 4.5 . 